\title{
LIBERAL STATEBUILDING INTERVENTIONS \\ AND THE MONOPOLY ON VIOLENCE
}

\author{
A thesis submitted for the degree of \\ Doctor of Philosophy \\ in
}

Political Science

by

Benjamin Brast

Submission: 26.01.2015

Defense: 04.09.2015

Klaus Schlichte

Peter Mayer

Christoph Zürcher

Bremen International Graduate School of Social Sciences 


\title{
Liberal Statebuilding Interventions and the Monopoly on Violence
}

\author{
Benjamin Brast
}




\section{Table of Contents}

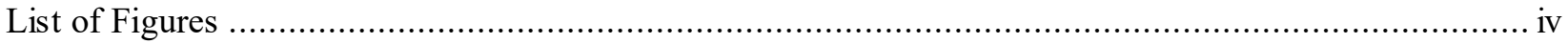

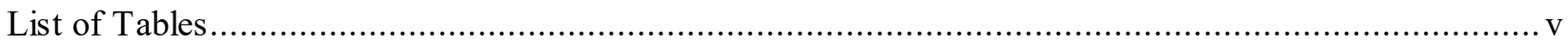

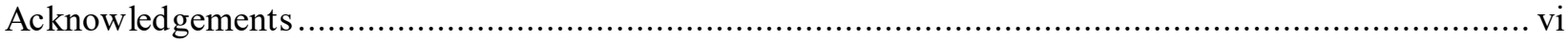

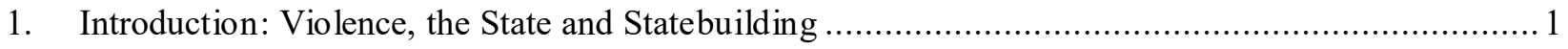

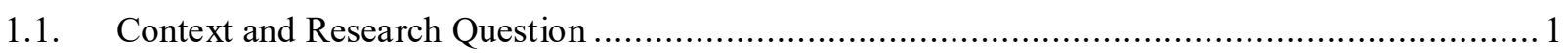

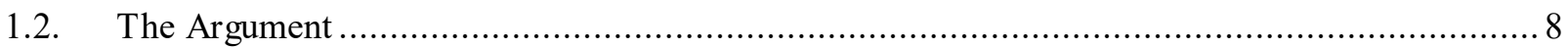

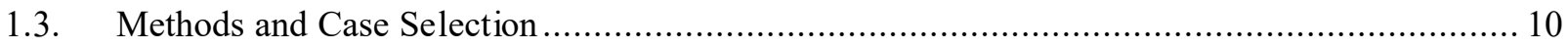

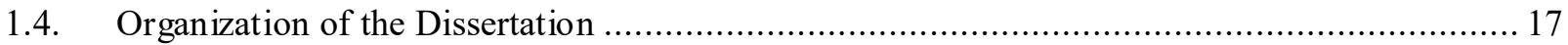

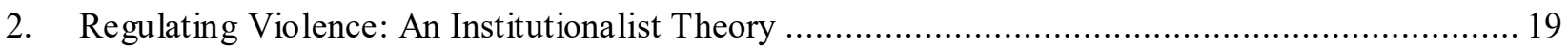

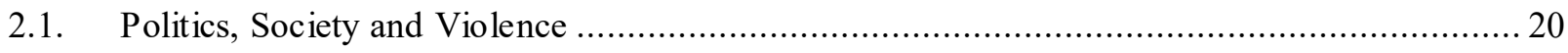

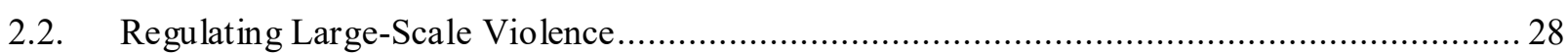

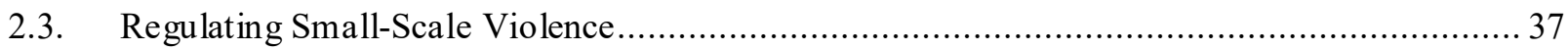

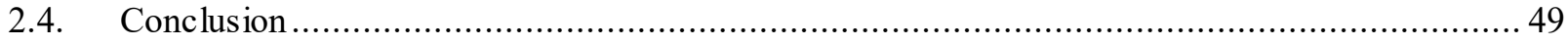

3. Liberal Statebuilding Interventions and the Regulation of Violence .................................... 51

3.1. Statebuilding Intervention and Large-Scale Violence .............................................. 53

3.2. Statebuilding Intervention and Small-Scale Violence .................................................... 64

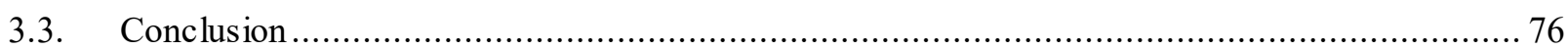

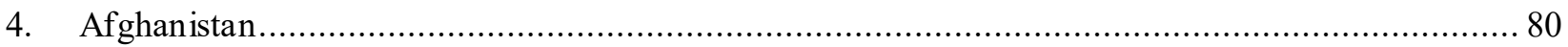

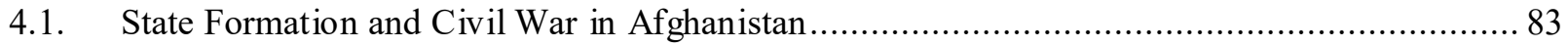

4.2. Statebuilding Intervention and Large-Scale Violence Regulation ................................. 90

4.3. Statebuilding Intervention and Small-Scale Violence Regulation .................................. 110

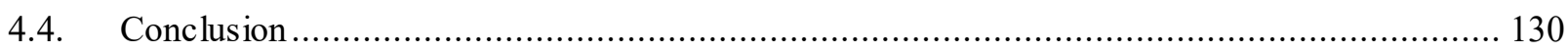

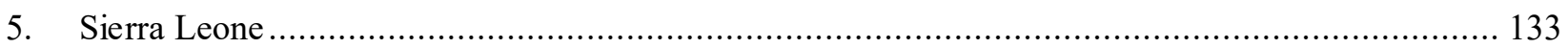

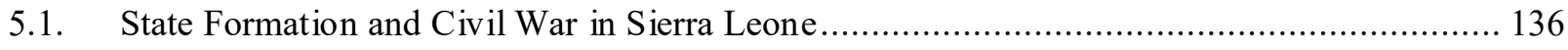

5.2. Statebuilding Intervention and Large-Scale Violence Regulation ............................... 144

5.3. Statebuilding Intervention and Small-Scale Violence Regulation ................................ 163

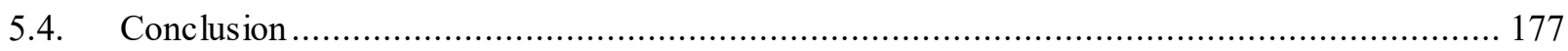

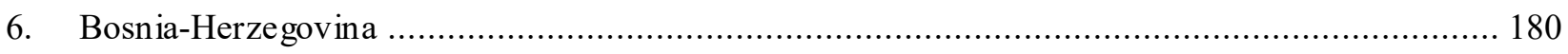

6.1. State Formation and Civil War in Bosnia and Herzegovina ......................................... 183

6.2. Statebuilding Intervention and Large-Scale Violence Regulation .................................. 189

6.3. Statebuilding Intervention and Small-Scale Violence Regulation .................................. 205

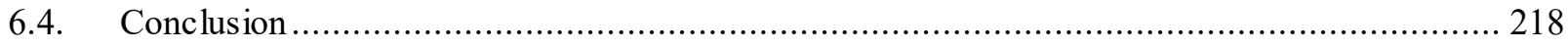

7. Conclusion: What Future for Statebuilding and State Formation? ........................................ 220

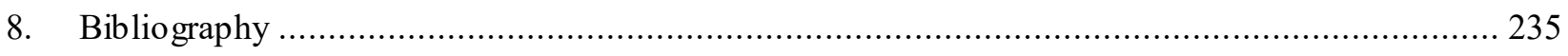

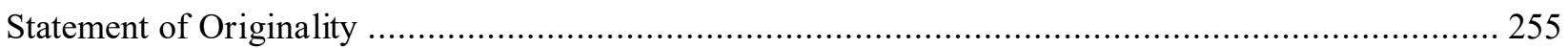




\section{List of Figures}

Figure 1: Battle-related deaths, Uppsala Conflict Data Set (UCDP 2014a).

Figure 2: Tax revenues as percentage of GDP ten years after the onset of statebuilding intervention

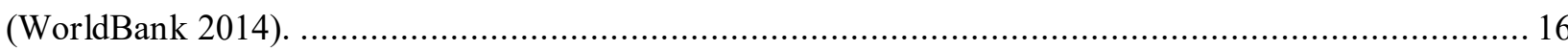

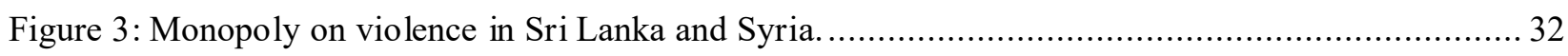

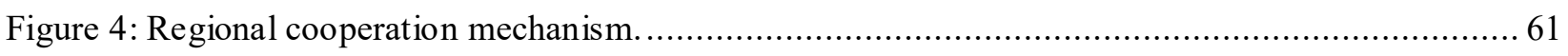

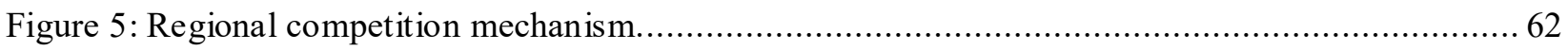

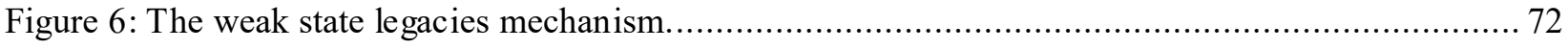

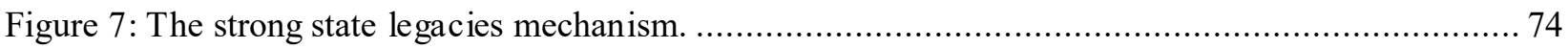

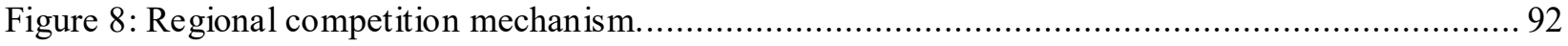

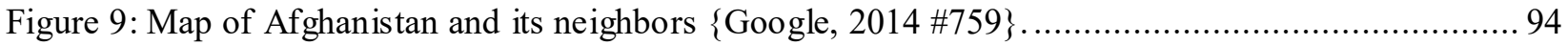

Figure 10: Number of Afghan National Security Forces, Afghan Local Police and IS AF troops. .......... 106

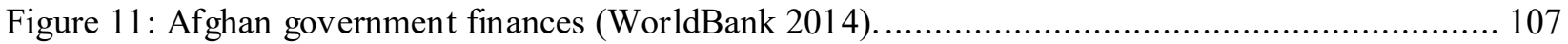

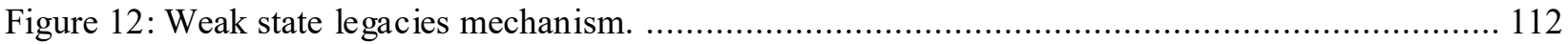

Figure 13: Answers to the question "Who did you report the crime to?". Figure reproduced from Afghan

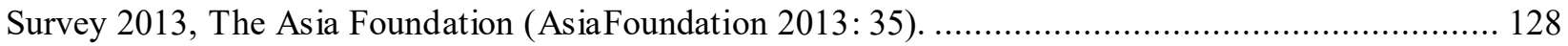

Figure 14: Question on attitude towards the ANP in 2013, item from Northeast Afghanistan Longitudinal

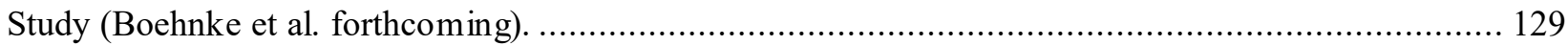

Figure 15: Question on attitude towards the ANP, item from Northeast Afghanistan Longitudinal Study

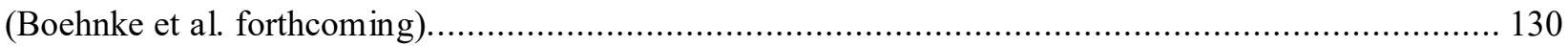

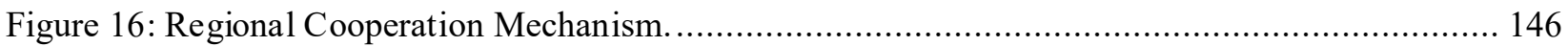

Figure 17: Map of Sierra Leone and the wider West African region (Google 2014). ........................ 149

Figure 18: Military expenditures of the Sierra Leonean state (WorldBank 2014). ............................ 160

Figure 19: Official development assistance for Sierra Leone in relation to government expenses

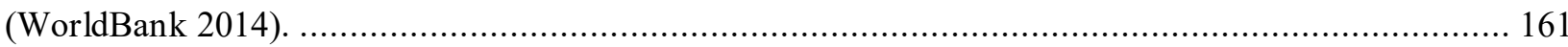

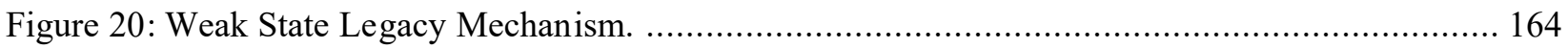

Figure 21: Demand for institutions of small-scale violence regulation in Sierra Leone (Afrobarometer

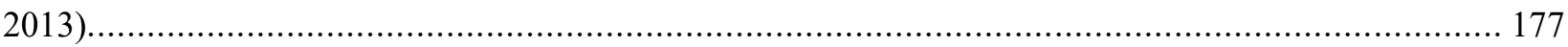

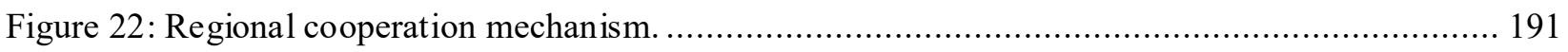

Figure 23: Map of the Western Balkans and its European neighborhood (Google 2014)................... 193

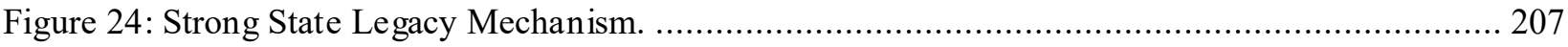




\section{List of Tables}

Table 1: Complete list of liberal statebuilding interventions. .................................................. 5

Table 2: Actors, resources, strategies and outcomes of statebuilding interventions. ............................ 15

Table 3: Statebuilding intervention and measures of small-scale violence monopolization. .................. 17

Table 4: "Monopoly on Violence" score of 129 countries in transition (BTI 2014a).......................... 25

Table 5: Actors of large-scale and small-scale violence regulation. ........................................... 27

Table 6: Institutions of large-scale and small-scale violence regulation. ....................................... 27

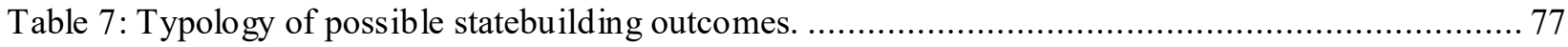




\section{Acknowledgements}

In accordance with the doctoral degree regulations of the Universität Bremen, preliminary results of this dissertation have been published in Brast, Benjamin (2015): "The Regional Dimension of Statebuilding Interventions", International Peacekeeping 22(1): 81-99. 


\section{Introduction: Violence, the State and Statebuilding}

\subsection{Context and Research Question}

Since the end of the Cold War, liberal statebuilding interventions have become an important practice in international politics. In statebuilding interventions, a liberal model of statehood is exported to societies governed by weak states. Among policy-makers and scholars alike, the dominant view of the state is still shaped by Max Weber's (Weber 1972: 824) classic definition of the state as the "[..] organization which successfully claims the monopoly on legitimate physical violence as means of political rule within a territory [..]"1. Although the modern state has many more characteristics, the regulation of violence is a core element of statehood (Pierson 2011). Thus, by definition building states entails the monopolization of the means of violence. The goal of this dissertation is to examine why some statebuilding interventions succeed in building a monopoly on violence while others fail. Before I provide an answer to this question, it is necessary to get a basic understanding of the issue at hand: Why do states and international organizations intervene militarily to export specific types of institutions of violence regulation?

Across developed states, it is taken for granted that the state controls violence. Violence has become a rare phenomenon in Europe and North America. While homicide and violent crime rates have reached historically low levels across the 'Western World' (Eisner 2001, 2003), war within or between Western states has become unthinkable (Dafoe 2011; UCDP 2014b). In an increasing number of these countries, the state has prohibited violence not just in public places such as schools but also in the private sphere of the family (Bussmann et al. 2009: 2-3). Scholars have argued that this demise of violence is not just a snapshot of recent developments but part of a long-term process that has unfolded over centuries. They have described the pacification of Western societies in emphatic terms as a 'Civilizing Process' (Elias 1939[2000]) that enables us to free 'The Better Angels of our Nature' (Pinker 2011). In contrast, civil wars and violent crime are much more prevalent in many parts of Africa, Asia and the Americas (UCDP 2014b; UNODC

\footnotetext{
1 '[..]daß der moderne Staat ein anstaltsmäßiger Herrschaftsverband ist, der innerhalb eines Gebietes die legitime physische Gewaltsamkeit als Mittel der Herrschaft zu monopolisieren mit Erfolg getrachtet hat $[. .]^{\prime}$
} 
2013: 22-27) ${ }^{2}$. In short, from the perspective of developed countries the world appears to be divided into violent and non-violent areas.

Against the backdrop of this gap between pacified societies in the West and a perceived omnipresence of violence in large parts of the rest of the world, the idea of liberal statebuilding has gained traction in foreign policy circles since the end of the Cold War (Wesley 2008: 376379). The logic behind statebuilding is simple: If the liberal, Western state has managed to clear society from the evils of war and violent crime, then exporting this institutional model could solve the violence problem in other countries, too (Richmond 2005). Since 1989, developed states and international organizations have increasingly identified state weakness as a key cause of poverty and violence. To address the problem, these actors have developed a set of strategies that can be broadly subsumed under the label external statebuilding: External support for "[..] the creation of new government institutions and strengthening of existing ones" (Fukuyama 2005: xvii). Statebuilding measures can be placed on a continuum ranging from minimal interference to highly intrusive policies. On the one side of the spectrum are instruments such as conditional loans by the International Monetary Fund that are meant to provide political elites with incentives for 'good governance' reforms. On the other side, there are large-scale military interventions that aim at the complete overhaul of state-society relations. This dissertation deals with the latter phenomenon: Liberal statebuilding interventions.

I define liberal statebuilding interventions as substantial military transgressions of a state's jurisdictions by other states or international organizations with the goal to establish a liberal state ${ }^{3}$ (Berdal and Zaum 2012; Call and Wyeth 2008; Reus-Smit 2013; Richmond 2005). Liberal statehood is characterized by a monopoly on violence, democracy, the rule of law, and a market-based economy. This model of statehood has the backing of Western ministries, international organizations, and a great number of social scientists alike (Wesley 2008: 376-379). The theory behind liberal statebuilding is that there are several ways in which liberal statehood

\footnotetext{
${ }^{2}$ In fact, the self-perception of Western societies is biased. A look at different world regions shows that Eastern Asia has also achieve comparatively low levels of both civil war and violent crime. What North America, Europe and parts of Asia have in common are strong states that have monopolized violence to historically unprecedented levels.

${ }^{3}$ The definition is a reformulation of Reus-Smit's definition of intervention: "International intervention is the transgression of a unit's realm of jurisdiction, conducted by other units in an order, acting singly or collectively. Interventions are always transformative; they are transgressions to reconfigure identities, institutions, and practices. And they are always justified. Interventions violate established principles of differentiation, and their legitimacy requires a normative defence" (Reus-Smit 2013: 1058).
} 
promotes peace and wealth (Paris 2004: 41-42 ; Richmond 2006: 291-293). First and foremost, the actors who intervene in weak state societies are usually liberal states. Policymakers have been socialized in this type of state, and they are accountable to an electorate that would hardly tolerate the export of illiberal institutions. In a nutshell, the rational-legal, liberal type of institution is the only one that is seen as legitimate in Europe and North America (Lake 2010b: 33-35). Furthermore, this ideology is underpinned mainly by two causal arguments of how weak and illiberal statehood leads to war. Scholars of civil war have found that weak governments and noninclusive institutions make violent conflict more likely (Fearon and Laitin 2003; Goldstone et al. 2010; Hegre et al. 2001). More indirectly, economists have emphasized the importance of 'good governance' (i.e. liberal institutions) for economic development (Acemoğlu and Robinson 2012; North 1990; North et al. 2009). Since poverty is one of the strongest predictors of civil war (Collier and Hoeffler 1998, 2004; Fearon and Laitin 2003), the logical conclusion is that liberal statehood will prevent a recurrence of war not only directly through strong and fair institutions, but also indirectly through economic development. Consequently, policymakers have accepted the creation of liberal institutions as the appropriate response to situations of 'state fragility'. The statebuilding consensus of the post-Cold War era is reflected by documents released by international institutions such as the UN (UN 2008b: 25-29), OECD (OECD 2007b), or the European Union (EC 2007: 8) as well as many governments ${ }^{4}$. A representative example of the view of European and North American governments is offered by the OECD that argues for a

Focus on state-building as the central objective. States are fragile when state structures lack political will and/or capacity to provide the basic functions needed for poverty reduction, development and to safeguard the security and human rights of their populations. International engagement will need to be concerted, sustained, and focused on building the relationship between state and society, through engagement in two main areas. Firstly, supporting the legitimacy and accountability of states by addressing issues of democratic governance, human rights, civil society engagement and peacebuilding. Secondly, strengthening the capability of states to fulfil their core functions is essential in order to reduce poverty. Priority functions include: ensuring security and justice;

\footnotetext{
${ }^{4}$ See for example the British Department for International Development (DFID 2010: 24-27), or the US Agency for International Development (USAID 2005: 7-8).
} 
mobilizing revenue; establishing an enabling environment for basic service delivery, strong economic performance and employment generation. (OECD 2007b: 2)

While the paragraph exemplifies the highly ambitious nature of liberal statebuilding, none of these ambitions can be achieved without the establishment of a monopoly on violence. A state monopoly on violence is a necessary condition for the more elaborate goals of liberal statebuilding. As long as non-state actors can use force to achieve their aims, democracy and the rule of law cannot properly function (Møller and Skaaning 2011). The official focus on the creation of 'security first' in post-war societies testifies to the importance of the monopoly on violence for statebuilding mission (BMZ 2012; DFID 2010: 28-29 ; USAID 2005: 3). A monopoly on violence is thus the most basic element of what statebuilding is supposed to achieve, yet a brief look at the outcomes (table 1) of interventions reveals great variation. Some interventions have resulted in a robust monopolization of force, while others seem to have no (positive) effect at all. This disparity of outcomes poses the major puzzle that my dissertation tries to solve. 


\begin{tabular}{|c|c|c|c|c|}
\hline Country & $\begin{array}{c}\text { Intervening } \\
\text { Actors }\end{array}$ & $\begin{array}{c}\text { Peak Troop } \\
\text { Deployment (per } \\
1,000 \text { capita) }\end{array}$ & Duration $^{5}$ & $\begin{array}{c}\text { BTI } 2014 \\
\text { Monopoly on } \\
\text { Violence } \\
\text { Score }(1-10)\end{array}$ \\
\hline Afghanistan & NATO & $150,000(5.9)$ & $2001-2014$ & 3 \\
\hline $\begin{array}{c}\text { Bosnia- } \\
\text { Herzegovina }\end{array}$ & UN, NATO, EU & $60,000(15.9)$ & $1995-2007$ & 8 \\
\hline $\begin{array}{c}\text { Central African } \\
\text { Republic }\end{array}$ & AU, UN & $10,000(2.3)$ & 2014 - ongoing & 1 \\
\hline Côte d'Ivoire & UN & $6,900(0.3)$ & 2004 - ongoing & 6 \\
\hline DR Congo & UN & $22,000(0.3)$ & 2004 - ongoing & 2 \\
\hline East Timor & UN, Australia/NZ & $11,000(10.3)$ & $1999-2012$ & $\mathrm{n} / \mathrm{a}$ \\
\hline Iraq & US-led coalition & $176,000(5.2)$ & $2003-2011$ & 4 \\
\hline Kosovo & NATO, EU & $50,000(27.5)$ & 1999 - ongoing & 6 \\
\hline Liberia & UN, ECOWAS & $15,000(3.5)$ & 2003 - ongoing & 8 \\
\hline Mali & UN & $9,132(0.6)$ & 2013 - ongoing & 3 \\
\hline Sierra Leone & $\begin{array}{l}\text { UN, UK, } \\
\text { ECOWAS }\end{array}$ & $17,500(2.8)$ & $1999-2005$ & 8 \\
\hline Somalia & AU, UN & $22,126(2.1)$ & 2007 - ongoing & 1 \\
\hline South Sudan & UN & $12,500(1.5)$ & 2011 - ongoing & 5 \\
\hline
\end{tabular}

Table 1: Complete list ofliberal statebuilding interventions.

Given the importance of violence regulation for statebuilding, my goal is to narrow down my analysis and focus on how liberal statebuilding interventions affect the regulation of violence in a given society. Hence, the main question this dissertation seeks to answer is: Under which conditions do statebuilding interventions succeed or fail to create a state monopoly on violence? There is a broad consensus among social scientists that the monopoly on violence is a core element of statehood (Migdal and Schlichte 2005: 15 ; Pierson 2011: 7). Among scholars of statebuilding interventions, there is agreement that statebuilding aims at the creation of a

5 "Ongoing" marks cases that were ongoing as of writing the dissertation, i.e. at the end of 2014. 
monopoly on violence ${ }^{6}$. Yet, they have neither clarified the concept nor have they offered systematic explanations for the varying outcomes of international attempts at monopolizing the means of coercion. In order to provide both an analytical framework and an explanatory theory, this dissertation adopts a neo-institutionalist view on violence regulation in which institutions are sets of rules that constrain and enable human action (Mayntz and Scharpf 1995: 43 ; North 1990: 3-6). Institutions are generally the outcome of bargaining between actors and therefore reflect the power relations at the time of institutional design. By locking in these power constellations, institutions create stability, but they can also preserve inefficient rules for long periods of times (Pierson 2004). Institutions that regulate violence are a core element of every social order. The natural urge to avoid becoming subject to violence gives violence a deterrence effect (Trotha 1995: 130-131). This deterrence effect makes violence an important source of power for those actors who are better at organizing means violence. In order to tame these powerful actors and to make violence productive for society, the access to and application of violence need to be regulated by institutions.

What do statebuilding interventions do to monopolize the means of coercion? In order to build liberal states with strong monopolies on violence, the 'international community' has developed a rather uniform set of statebuilding intervention strategies during the last two decades. Disarmament, Demobilization and Reintegration (DDR) and Security Sector Reform (SSR) have become the key strategies of monopolizing the use of force. Initially, interveners have experimented with different styles of intervention. In Namibia, complex peacekeeping meant that external actors would support a peace and democratization process that was implemented by local actors. This institution-building exercise proved highly successful (Paris 2004: 135-141). A subsequent large-scale mission in Cambodia which monitored elections in the aftermath of civil war largely failed. After the UN had withdrawn, the conflict continued. During the trial and error phase in the 1990s, the interveners developed strategies of how to conduct their interventions, among them DDR and SSR. By making DDR a standard approach to statebuilding, the international community acknowledged that in order to achieve peace, armed groups needed to be disarmed and former combatants had to be reintegrated into society (Knight and Özerdem 2004: 499-501 ; UN 2014: 1). Hence, DDR can be seen as the first step towards a monopoly on

\footnotetext{
${ }^{6}$ The monopoly on violence is accepted by scholars of all stripes as a key feature of statebuilding (Bliesemann de Guevara 2012: 7 ; Lake 2010b: 31 ; Mac Ginty 2010b: 580-581 ; Paris and Sisk 2009: 1).
} 
violence. SSR is a more complex concept and combines several elements that taken together are meant to create a liberal security architecture. Security sector reforms entail two core features. First, they endow governments with organizational capacities in the form professional armed forces and police forces. Second, SSR creates institutional frameworks that are meant to regulate the coercive apparatus and make it democratically accountable (Jackson 2011: 1085-1090). Since the mid-1990s, the combination of DDR and SSR has become the typical strategy for external statebuilders who seek to build a monopoly on the use of force.

What answers does existing research on statebuilding offer us for explaining the variation in outcomes? ${ }^{7}$ The phenomenon of statebuilding has attracted a lot of scholarly attention, and there has been a first 'great debate' on statebuilding and peacebuilding in which 'problem-solving scholars' and 'critical scholars' were pitted against each other (Bliesemann de Guevara 2012: 24). The problem-solvers have sought to produce scholarly work that is useful to practitioners. Hence, they have focused on the strategies and resources employed by intervening actors to analyze statebuilding. Their arguments have thus focused on how to increase statebuilding effectiveness by improving these external factors (Chesterman 2004; Dobbins 2007; Paris 2004). If the problem-solvers were right, we should expect that statebuilding interventions have performed better where external actors have committed more resources and have conducted wellplanned DDR and SSR campaigns. Furthermore, statebuilding should become more successful over time as the actors learn from past mistakes and adjust their strategies. A brief glance at the cases reveals that the exclusive focus on external factors cannot account for the great variation in intervention outcomes. Well-resourced interventions have produced vastly different outcomes, as have interventions with sophisticated DDR and SSR strategies. Furthermore, failures in the latest statebuilding endeavors (e.g. South Sudan) indicate that the (actually occurring) learning process had little impact on the ability of intervening actors to establish monopolies on violence.

'Critical scholars' have questioned the very assumptions behind interventions and have criticized the problem-solvers for ignoring the social structures in the countries where statebuilding took place (Mac Ginty and Richmond 2007; Pugh 2004; Richmond 2005). The introduction of local actors and structures into the debate was important as these factors help understand why statebuilding is much more difficult than policymakers and scholars had

\footnotetext{
${ }^{7}$ For a detailed literature review, see chapters 3.1 and 3.2.
} 
anticipated in the 1990s. However, the literature focused largely on failure. If strong local actors prevent the monopolization of violence, how can variance across cases with strong local actors be explained? In sum, while this first debate was extremely fruitful and serves as a foundation for any further research on peacebuilding, both sides have largely failed to provide systematic explanations for the outcomes of statebuilding interventions (Zuercher et al. 2013: 4-5). In recent years, a new generation of scholarship has put a stronger focus on explaining statebuilding outcomes by adopting a more comparative perspective ${ }^{8}$. My dissertation aims at contributing to this new generation of comparative statebuilding research.

\subsection{The Argument}

This dissertation offers one conceptual innovation and makes one major causal argument. First, I offer a theoretical clarification of the concept of 'monopoly on violence', arguing that the modern state has monopolized two different types of violence: Large-scale violence and small-scale violence. A state has a monopoly on violence when it has monopolized large-scale violence and small-scale violence regulation. Second, based on this distinction I develop an explanation for why statebuilding interventions succeed or fail at monopolizing the means of violence. My argument is that liberal statebuilding interventions lead to a state monopoly on violence when the intervention is supported by key regional actors and when the target society had a history of strong statehood prior to civil war. The following paragraphs will briefly summarize my argument.

Large-scale violence denotes organized violence. The means of large-scale violence thus consist of any type of organization that is able to wage war. A state has a monopoly on largescale violence when the government is the only actor on the territory of the state that controls organizations capable of waging war (i.e. armed forces). As the literature on state formation shows, the modern state has developed within a regional state system. Statehood as an institution of large-scale violence divides a region into clearly demarcated territories in which only one actor (i.e. the government) is allowed to control the means of warfare. Therefore, I argue that liberal statebuilding interventions are highly likely to succeed in establishing a state monopoly on large-

\footnotetext{
${ }^{8}$ For a detailed discussion of the literature, see chapter 3.
} 
scale violence when key regional actors support the intervention. Statebuilding interventions supply the government of a state with organizational capacities of large-scale violence for a limited period of time: They provide troops as long as the state is too weak, they train and equip armed forces, and they provide the government with the money to fund this coercive apparatus. However, their ability to eventually monopolize the means of warfare depends on whether they succeed at disarming non-state armed groups. Where these armed groups have access to sanctuaries across borders, they can sustain their operations, evade disarmament, and drive up the costs of statebuilding. Given the time constraints of interveners, a withdrawal without monopolization becomes highly likely.

Small-scale violence describes the application of violence at the inter-personal level. Every human being can be violent, and applying small-scale violence requires only minimal organizational capacities at the local level. Small-scale violence can never be fully monopolized, but actors can have a monopoly on small-scale violence regulation. A state has a monopoly on small-scale violence regulation when it is the only actor with the ability to make and enforce collectively binding rules. In order to fulfill this function, the modern state has developed an institutional framework of legal monism and a bureaucratic police to enforce rules. The alternative to state order are self-help communities, i.e. local non-state institutions which provide a set of rules (such as customary or religious laws) and (violent and non-violent) enforcement mechanisms. Since self-help communities are highly resilient institutions, this dissertation argues that liberal statebuilding interventions will only lead to a state monopoly on small-scale violence regulation in countries which had a history of strong statehood prior to civil war. The rationale behind this line of argument is that the monopolization of small-scale violence is a complex bargaining process between the central government and local elites. Governments have to build bureaucratic institutions of local government (administration, police, etc.), but they also have to deal with the local elites that owe their power to self-help communities. Often times, the central government depends on the support of these local elites for maintenance of order. As a result, many interventions create para states in which both self-help communities and state institutions regulate small-scale violence. In contrast, interventions in societies that have experienced a history of strong statehood are likely to succeed in monopolizing small-scale violence regulation because the state does not have to compete with self-help communities. 
After having presented my argument in a nutshell, the following section discusses the methods I applied in my dissertation and elaborate on the case selection.

\subsection{Methods and Case Selection}

\section{Methods}

In order to increase transparency, it is necessary to make my basic social scientific assumptions explicit before discussing specific methods. When I put my explanations to the test, I am following a Bayesian view of truth. Unlike Popper's logic of falsification where a hypothesis can only be refuted (i.e. falsified) through empirical tests, "[..] Bayesian logic posits that we can both confirm and disconfirm our confidence in the validity of a theory - although given the uncertain nature of empirical observation, we can never be 100 percent confident about either confirmation or disconfirmation" (Beach and Pedersen 2013: 83). Both my explanation and other explanations might be plausible. The question is how likely it is to find certain evidence given that either my explanation or rivalling explanations are correct (Beach and Pedersen 2013: 83-85). One could thus liken a specific explanation (i.e. a model) to a map: It is useful because it helps us navigate the world through simplifications even though it leaves out large parts of reality. Some maps are better suited than others for specific purposes (Clarke and Primo 2012: 12-14). Therefore, the strongest possible conclusion I can reach is that my explanation is better suited than existing theories to understand and to explain the effects of statebuilding interventions on violence regulation.

The dissertation is conceptualized as a comparative historical analysis, a type of research that is "[..] defined by a concern with causal analysis, an emphasis on processes over time, and the use of systematic and contextualized comparison" (Mahoney and Rueschemeyer 2003: 6). I assess my theoretical explanations within and across three case studies. Comparing several cases in a most similar systems design increases the confidence with which I can rule out alternative explanations before entering the case studies (Rohlfing 2012: 133-136). In order to conduct causal analysis within the case studies, I make use of the latest advances in qualitative social scientific methods (Beach and Pedersen 2013; Goertz and Mahoney 2012; Rohlfing 2012). Within each case I apply process-tracing, a method that entails the formulation of causal 
mechanisms which are then put to the test in case studies. Process-tracing allows researchers to make stronger claims about the causal connection within single case studies, because they can show how the initial cause translated into the observed outcome step by step (Beach and Pedersen 2013). Throughout my research, I have combined deductive and inductive elements: I have constructed basic theoretical expectations about the relation of violence, actors and institutions by deducing them from the state formation literature and research on statebuilding. These expectations (or priors) were then combined with empirical material from the cases and updated accordingly. Through this theory-building process-tracing, I was able to develop a novel theoretical explanation for the effect of statebuilding interventions on violence regulation (Beach and Pedersen 2013: 60-61). Additionally, each case study (as well as this introductory chapter) further incorporates congruence analysis. In congruence analysis, the researcher compares the explanatory power of his own hypothesis to rivalling (or complementary) explanations (Beach and Pedersen 2013: 4-5). In the case studies, I especially look at case specific explanations that have been advanced by other scholars.

The data I analyze in both the comparison and process-tracing is a combination of official documents, leaked documents, datasets, newspaper articles, and a large body of secondary literature that has been conducted on the specific cases at hand. As the types of data indicate, the goal of this dissertation is not to provide new data or insights from the field, but to develop a theory that can explain phenomena in a strictly limited population.

\section{Universe of Cases - What is a liberal statebuilding intervention?}

For the purpose of this dissertation, I narrow down the focus to interventions with wide-ranging statebuilding goals and a strong military component. By doing so, my research design takes only those cases into account in which external actors were strongly committed to intervention and liberal statebuilding. Most peacebuilding activities are conducted by the UN, EU, NATO or any OECD member state are conducting contain some elements of liberal statebuilding. With respect to peacebuilding, Berdal and Zaum (Berdal and Zaum 2012: 2) argue that "[out] of a total of 49 UN-led peacekeeping operations established between 1989 and 2011, 29 had some form of statebuilding mandate". However, the great variance of these statebuilding activities, from monitoring elections to all-out institution-building, makes comparisons across cases difficult. 
Therefore, I only classify missions as a statebuilding interventions when they meet certain criteria with regard to resource input (troops), strategy (liberal institution-building) and duration (in years). In table 1, I have summarized all cases that qualify as statebuilding interventions (SBIs). In order to be counted as an SBI, the intervention has to aim at building a liberal state through institution- and capacity-building (SSR), and there needs to be a military deployment of at least 5,000 troops 9 . Furthermore, interventions should at least last three years in order to have an impact (and as a further signal for serious external commitment).

While these thresholds are somewhat arbitrary, they are useful to distinguish statebuilding interventions from less intrusive forms of external state support (like conditional aid, peacekeeping, or election monitoring). For example, the UN mission in Cambodia encompassed a military component of 15,900 troops, but it only monitored elections and was not geared towards building a stronger state. UNSOM II in Somalia was a 28,000-strong intervention with statebuilding goals, but it was aborted after only two years due to the premature withdrawal of US forces. Similarly, UNMIH in Haiti (6,000 troops, SSR-component) was too short-lived to count as a genuine statebuilding intervention, and its successor mission MINUSTAH does not seek to build a monopoly on large-scale violence ${ }^{10}$. In contrast, the newly established missions in the Central African Republic ( 10,000 troops) and Mali ( 9,000 troops) are highly likely to become part of the universe of cases as they fit the pattern of long-term peacekeeping commitment in Africa. However, as of 2014 it is too soon to count them as cases. Nevertheless, I have chosen to include ongoing missions. While it could be argued that it is inappropriate to assess inconclusive interventions, excluding them would lead to a massive selection bias. Unsuccessful missions tend to last longer as interveners face a sunk cost problem and therefore often postpone withdrawal. However, only by including them is it possible to get a realistic picture of success and failure in statebuilding interventions.

Table 1 lists all relevant cases and reveals several important aspects. First, the set of actors is rather homogenous. Most interventions were UN peacekeeping missions that entailed a strong statebuilding component. While most other interventions were conducted by NATO states or the US (often in cooperation with the UN), the AU has established itself as a major player in

\footnotetext{
${ }^{9}$ As brigades have become the largest operational unit of many armed forces, the approximate size of one brigade could be seen as a minimum threshold for meaningful military operations.

${ }^{10}$ The Haitian army has been abandoned.
} 
peace- and statebuilding. Second, many interventions did not start out as statebuilding interventions but actually developed into such through a series of UN mandates. For example, UNOCI, the UN mission in Côte I'Ivoire, had been initially tasked with monitoring the implementation of a 2003 peace agreement. After the 2010 Presidential elections, however, DDR and SSR components were added. Thus, statebuilding interventions are often the result of 'mission creep'. Third, a strong troop presence or SSR programs are apparently not sufficient to guarantee a monopolization of violence. Fourth, despite debates about the demise of the statebuilding paradigm and an increasing reluctance of Western states to directly participate in statebuilding, several missions have only commenced in recent years. Statebuilding seems to continue to be a viable policy option, especially for UN missions. Fifth and finally, the outcome varies widely, from cases where immense external commitment fails to create minimal statehood to cases where weak states are provided with solid coercive capacities. How can we explain the wide disparities in outcomes? The next section presents the case selection criteria and probes into some of the more general explanations that are offered in the literature.

\section{Case Selection}

My case selection seeks to include similar cases with varying outcomes on both large-scale violence and small-scale violence. Furthermore, my argument will be strengthened by selecting cases where the statebuilding intervention has officially ended. I select Afghanistan, BosniaHerzegovina and Sierra Leone for my case studies. These three cases are all cases of liberal statebuilding interventions, but their outcomes differ. The creation of a monopoly on large-scale violence succeeded in Bosnia-Herzegovina and Sierra Leone. The monopolization of small-scale violence regulation has succeeded only in Bosnia-Herzegovina. In order to clarify my choice, the following paragraphs briefly compare the cases. However, it is difficult to find quantitative data that measures the two concepts of violence I develop in this dissertation. As George and Bennett remind us, "[c] ase studies allow a researcher to achieve high levels of conceptual validity, or to identify and measure the indicators that best represents the theoretical concepts the researcher intends to measure. Many of the variables that interest social scientists, such as democracy, power, political culture, state strength, and so on are notoriously difficult to measure" (George 
and Bennett 2005: 19). With that caveat in mind, I present rough proxies of my two outcomes for illustrative purposes.

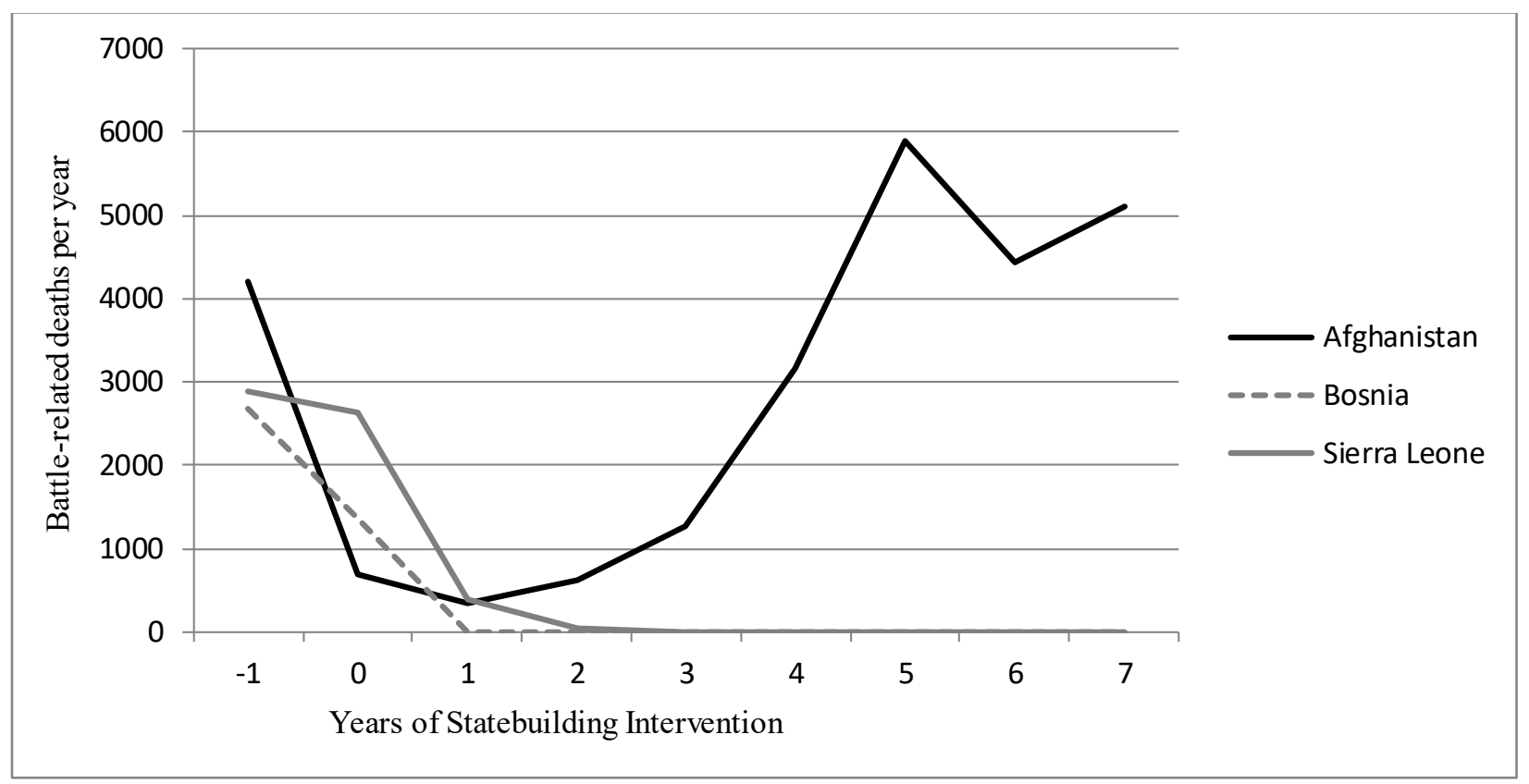

Figure $1^{11}$ : Battle-related deaths, Uppsal a Conflict Data Set (UCDP 2014a).

The number of battle-related deaths could be used as a rough proxy for the existence or absence of a monopoly on violence (see figure 2). At first glance, the figure seems to confirm my assessment of the cases. However, the measure is problematic as it conceals the fact that BosniaHerzegovina was divided among two major armed actors. There was no open conflict, but also no state monopoly on large-scale violence. Similarly, the number of armed actors can be misleading as the case of Afghanistan shows. At the beginning of the statebuilding exercise, the Afghan state relied on the Afghan Military Force. While formally the AMF was one military organization under state control, it consisted of an alliance of several militias and their political control was questionable. Nevertheless, the number of battle-related deaths reflects the degree of institutionalization of violence control to a certain extent. As the case studies show in detail, Bosnia-Herze govina acquired a monopoly on large-scale violence in 2005 when the armed forces of the two constitutive entities were merged into a new Bosnian army. In Sierra Leone, the defeat

\footnotetext{
${ }^{11}$ As the starting year, I chose the year in which the international mission officially started (ISAF 2002; IFOR 1995; UNAMSIL 1999).
} 
of the RUF paved the way for a reconstruction of the Sierra Leonean Armed Forces, enabling them to control the territory and deter the formation of new armed groups. In contrast, Afghanistan was mired in civil war throughout the twelve years of statebuilding.

This great variation cannot be fully accounted for by existing explanations. The focus of 'problem-solvers' on the intervening actors would suggest that the statebuilders had different goals or have used greatly differing sets of strategies across the three cases. As table 2 illustrates, a very similar set of actors was involved in the three interventions. The $\mathrm{UN}$ always played a role, although its involvement differed from case to case. Furthermore, in all cases Western-dominated institutions or Western states also played a major role. In terms of resources, all cases saw large troop deployments. However, both the biggest and smallest per capita deployment were successful cases (Bosnia-Herzegovina and Sierra Leone) whereas the case in between was a failure (Afghanistan). The critical scholars' emphasis on the misfit between liberal SSR policies and the local context also remains unsatisfactory. While Bosnia-Herzegovina is an industrialized society, both Afghanistan and Sierra Leone share factors that are commonly identified as problematic: Poverty, strong traditional and local institutions, long-term violent conflict and ethnic heterogeneity. Thus, existing explanations fail to account for the variation in outcome.

\begin{tabular}{|c|c|c|c|c|}
\hline Case & Actors & $\begin{array}{lr}\text { Resources } & \\
\text { (Peak troop } & \\
\text { deployment per } & \\
1,000 \text { capita) } & \end{array}$ & Strategies & Outcome \\
\hline Afghanistan & $\begin{array}{l}\text { NATO, UN, } \\
\text { USA }\end{array}$ & $\begin{array}{l}5.9 \\
(150,000 \text { in total })\end{array}$ & $\begin{array}{l}\text { Delayed DDR } \\
\text { program, long- } \\
\text { term SSR }\end{array}$ & $\begin{array}{l}\text { Dispersed } \\
\text { Means of } \\
\text { Large-Scale } \\
\text { Violence }\end{array}$ \\
\hline $\begin{array}{l}\text { Bosnia- } \\
\text { Herzegovina }\end{array}$ & $\begin{array}{l}\text { EU, NATO, } \\
\text { UN }\end{array}$ & $\begin{array}{l}15.9 \\
(60,000 \text { in total })\end{array}$ & $\begin{array}{l}\text { Delayed DDR } \\
\text { program, long- } \\
\text { term SSR }\end{array}$ & $\begin{array}{l}\text { Monopoly on } \\
\text { Large-Scale } \\
\text { Violence }\end{array}$ \\
\hline Sierra Leone & UK, UN & $\begin{array}{l}2.8 \\
(17,500 \text { in total })\end{array}$ & $\begin{array}{l}\text { Immediate DDR } \\
\text { program, long- } \\
\text { term SSR }\end{array}$ & $\begin{array}{l}\text { Monopoly on } \\
\text { Large-Scale } \\
\text { Violence }\end{array}$ \\
\hline
\end{tabular}

Table 2: Actors, resources, strategies and outcomes of statebuilding interventions. 
Finding a good proxy for the regulation of small-scale violence poses an even greater challenge. The number of police officers tells us nothing about the importance of non-state institutions for small-scale violence regulation, as both can co-exist. Furthermore, output data such as homicide rates could indicate the effectiveness (or lack thereof) of both state and non-state institutions. A potentially helpful indicator is the capacity of a state to tax its population. In the study of state formation, 'extractive capacity' has often been used as a proxy for the capability of the state to police its population (Hendrix 2010; Thies 2010; Thies 2004; Tilly 1992). Where non-state institutions regulate small-scale violence, local elites are either officially tasked with collecting taxes or have many opportunities to use public offices for rent-seeking. Hence, taxation is highly inefficient in para states. In contrast, where the state has a monopoly on small-scale violence regulation it can tax its population directly. This allows for much more efficient taxation. A look at the three cases reveals that a decade after the onset of the statebuilding intervention, there is a clear divide between the case of Bosnia-Herzegovina where no self-help communities existed compared to those cases with strong local elites. These values are also remarkably stable over time, indicating the stability of social order at the local level.

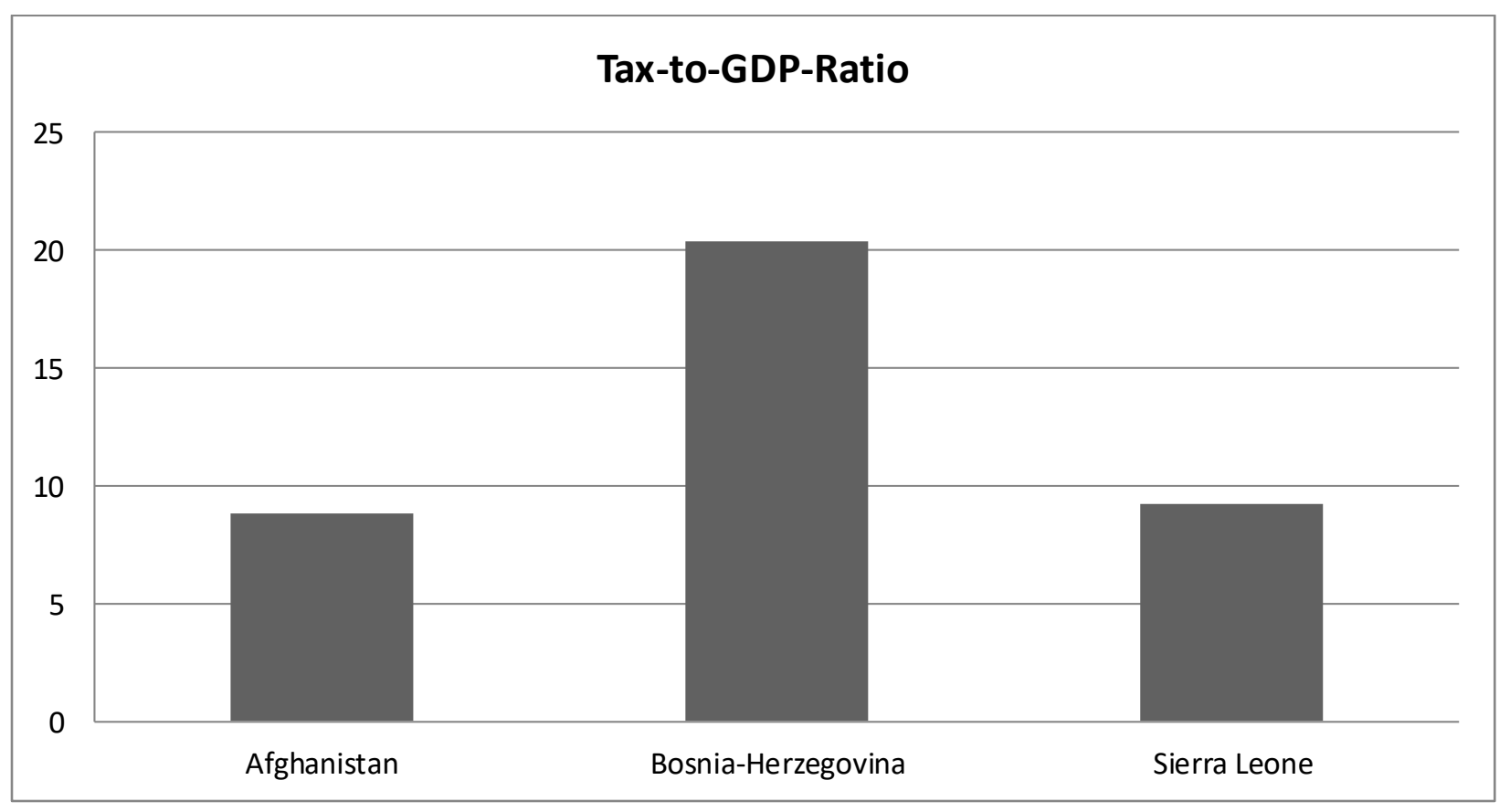

Figure 2: Tax revenues as percentage of GDP ten years after the onset of statebuilding intervention (WorldBank 2014). 
Assumptions about a power vacuum were false in all three cases. While the Bosnian policing institutions proved robust throughout the war (and were instrumental in ethnic cleansing), Afghanistan and Sierra Leone had strong self-help communities when the interventions began. As table 3 illustrates, the interventions all pursued similar trajectories in terms of institutional reform and capacity-building. Thus, the adopted strategies cannot fully explain the variation in outcomes. Nevertheless, existing research offers some helpful clues for explaining the effects of statebuilding interventions on the regulation of small-scale violence. As the case studies will show, the local institutions of small-scale violence and their relation to the central government are the crucial variable for explaining the outcomes.

\begin{tabular}{llll}
\hline Case & $\begin{array}{l}\text { Institutional } \\
\text { Reform }\end{array}$ & Capacity-Building & Outcome \\
&
\end{tabular}

\begin{tabular}{llll}
\hline Afghanistan & $\begin{array}{l}\text { New constitution, } \\
\text { reform of local } \\
\text { government }\end{array}$ & $\begin{array}{l}\text { Newly established } \\
\text { Afghan National Police } \\
(150,000)\end{array}$ & $\begin{array}{l}\text { Dispersed } \\
\text { Regulation of } \\
\text { Small-Scale } \\
\text { Violence }\end{array}$ \\
Bosnia-Herzegovina & $\begin{array}{l}\text { New constitution, } \\
\text { entity-based } \\
\text { policing system }\end{array}$ & $\begin{array}{l}\text { Police reform, training } \\
\text { for entity police forces } \\
(16,000)\end{array}$ & $\begin{array}{l}\text { State Monopoly } \\
\text { on Small-Scale } \\
\text { Violence }\end{array}$ \\
& Constitutional & Reconstruction of Sierra & $\begin{array}{l}\text { Regulation } \\
\text { Dispersed } \\
\text { reform, reform of }\end{array}$ \\
& Leone Police $(9,300)$ & Regulation of \\
local government & & Small-Scale \\
& & & Violence \\
\hline
\end{tabular}

Table 3: Statebuilding intervention and measures of small-scale violence monopolization.

\subsection{Organization of the Dissertation}

The dissertation consists of two major parts: The first part develops the theoretical argument in two chapters. The introduction is followed by a chapter that distills the core theoretical 
assumption about the relations of social order, institutions and violence regulation from state formation theory. It examines what we know about the role of violence in politics and society and develops an institutionalist perspective on violence regulation, arguing that two types of violence exist: Large-scale violence and small-scale violence. It then proceeds to take stock of what we know about the monopoly on violence and its historical emergence. Eventually, it builds a typology of state types based on their institutions of violence regulation.

Chapter three takes this basic theoretical framework and applies it to statebuilding interventions. The chapter both discusses existing theories and presents findings from my case studies. I examine common strategies of monopolization and review the literature in order to extract the knowledge we have about the effects of statebuilding interventions on both large-scale violence and small-scale violence regulation. By combining these inductively gained insights with my theoretical framework, I develop two causal mechanisms for each type of violence regulation.

The second part of the dissertation focuses on the empirics of statebuilding and the monopolization of violence. It consists of three chapters, each of which contains a case study that will test the causal mechanisms. Afghanistan is the case in which the intervention failed on both outcomes, intervention in Sierra Leone has led to a monopoly on large-scale violence but not on small-scale violence regulation, and monopolization in Bosnia-Herzegovina succeeded entirely. The case studies broadly confirm the hypotheses but also highlight important differences between cases with similar outcomes. The dissertation concludes by probing the plausibility of the theory for other cases of statebuilding intervention and by putting the findings into its broader political and scientific context. 


\section{Regulating Violence: An Institutionalist Theory}

This chapter develops a theoretical perspective on the social regulation of violence. In order to explain why some statebuilding interventions fail or succeed to build a monopoly on violence, it is necessary to first clarify the basic concepts of my analysis. In particular, this chapter examines the relation of political institutions and violence. Based on the literature on state formation, I argue that there are two types of violence that larger societies need to regulate: Warfare (largescale violence) and violence at the inter-personal level (small-scale violence). The unique feature of the modern state is that it has monopolized the regulation of both types of violence. In the following sections, I develop a theoretical framework that shows which actors, institutions, and processes are involved in the regulation of violence at the macro and micro level.

In the first part of the chapter, I argue that modern statehood is a regional institution which regulates large-scale violence. It regulates large-scale violence by limiting the means of warfare to governments, and by limiting each government's monopolistic claims to a clearly defined territory. It is widely accepted that governments need to develop organizational capacities to maintain a monopoly on large-scale violence: a strong army, and the extraction of resources from society (Thies 2004; Tilly 1992). Where governments fail to monopolize large-scale violence, outcomes can range from power-sharing arrangements among warlords to outright civil war. It is often assumed that a government has achieved 'statehood' once it has established these coercive capacities. However, without territorial borders there could never be a monopoly on violence (except on a global scale). Political elites that control means of large-scale violence and rule over populations need to reach agreement over the rules of statehood, i.e. that borders are fixed, that the rule within these borders is exclusive, and that only states can legitimately enter 'inter-unit' political relations. While the norm of sovereign statehood as defined by a monopoly on violence within a given territory has become globally accepted (Migdal and Schlichte 2005: 15-19), this has not translated into a world of strong states; state weakness tends to cluster in certain regions (Gleditsch 2007: 295). What sets the regional level apart from the global level is the spatial proximity: Political actors do not have to interact on the global level (although they increasingly do), but they necessarily interact at the regional level. Thus, the monopolization of large-scale violence necessitates both coercive organizational capacities and a regional institutional setting. 
The second part of the chapter argues that there are two possibilities to regulate smallscale violence: Self-help communities and state orders. I adopt the distinction between these two types of order from Trutz von Trotha (1995: 131) ${ }^{12}$. All societies have developed institutions that regulate small-scale violence at the local level. The state regulates small-scale violence through bureaucratic structures that are ultimately backed up by the enforcement capacities of the police. In state orders there is no room for non-state rules, and private actors are only allowed to enforce rule when the state delegates the task (Trotha 1995: 132-133). However, this form of state regulation is a fairly recent phenomenon. Self-help communities are the historic norm. These institutions can assume very different forms as they have developed in specific local contexts, but they always entail a system of rules as well as elites which guarantee rule enforcement. Today, many states are para states; these societies regulate small-scale violence through a combination of self-help institutions and state policing (Trotha 1995: 141-146).

On a cautionary note, the application of existing state formation models to other world regions has to be conducted carefully because the literature is mostly based on the European experience. I reduce the potential bias in part by including the small but growing body of research on state formation in Africa, Asia and the Americas. However, I hope to convince the reader that the basic needs and challenges of violence regulation are universal, and that building the most successful institution of violence regulation (i.e. the modern state) is always accompanied by a basic set of problems. Thus, many insights from state formation scholars are of great value for the study of statebuilding interventions. The chapter will develop the argument by first discussing the role of violence regulation for society in general and politics in particular. Building on a neoinstitutionalist framework, it will then proceed to theorize first the issue of large-scale violence regulation followed by small scale violence regulation.

\subsection{Politics, Society and Violence}

This section argues that all societies seek to regulate violence because all humans are capable of being violent while also fearing to be subjected to violence. This dual nature is a distinguishing feature of violence: Violence itself is destructive while the threat of violence can be productive,

\footnotetext{
${ }^{12}$ In contrast to von Trotha, I apply the distinction exclusively to small-scale violence regulation.
} 
for example by deterring people from breaking the law. The second part of the section argues that the modern state has evolved as an institution that is highly successful in regulating violence. Finally, I introduce the distinction between large-scale and small-scale violence.

\section{Violence and Institutions}

All human societies have developed sets of rules that regulate under which circumstances specific actors are allowed to use violence. Violence is an important research object for social scientists, and there is no shortage of studies on violence. These range from explanations of domestic violence (Collins 2008) to explanations of inter-state war (Bremer 1992). With regard to intervention, scholars have analyzed whether interventions can end ongoing violence (Fortna 2004), and why violence resumes during or after interventions (Berdal and Suhrke 2012). While this wide range of violence scholarship seems to be only loosely connected, there is a general tendency in the social sciences to treat violence as a phenomenon that is an exception from the norm and, thus, heeds explanation (Koloma Beck and Schlichte 2014: 22-25). Violence is rarely seen as an ubiquitous condition of human existence, and few contemporary authors have concerned themselves with the ordering effects of violence (North et al. 2009). What complicates the matter is that there is a variety of social scientific concepts of violence, and some of these conceptualizations are very broad and encompassing (Kalyvas 2008: 19). However, concepts such as 'structural violence' or 'cultural violence' (Galtung 1990) make it difficult to determine where violence ends and other related phenomena such as coercion, inequality, or power begin. Furthermore, these structuralist approaches leave only scant space for agency and, thus, change.

This dissertation will adopt a very simple definition of violence as "[..] the deliberate infliction of harm on people" (Kalyvas 2008: 19). The effects of violence on the victim are immediate and irreversible (Popitz 2004: 43-46). Since people do not want to become subjected to violence, the threat of violence can have a strong impact on their behavior (Tilly 1992: 70-71). Because "[..] violence performs a communicative function with a clear deterrent dimension [..]" (Kalyvas 2008: 26), threatened individuals are likely to do what they would not do otherwise. The threat of violence with the goal to alter other actors' behavior can be conceptualized as coercion. Thus, the fact that individuals or organizations can coerce others' behavior into certain directions makes control over the means of violence one of the most potent sources of power 
(Dahl 1957: 202-203 ; Weber 1972: 28-29). Since the ability to control means of violence is a primary source of power, the regulation of violence is essential to all societal orders. Without institutions that regulate violence, there could hardly be any stable social relations as all individuals would constantly live under the threat of being harmed by others (cf. North et al. 2009). As Popitz (2004: 190) argues: "No encompassing social order is built on the premise of nonviolence. The power to kill and the powerlessness of the victim are latent or manifest determinants of social structures" ${ }^{\prime 13}$.

The social regulation of violence necessitates the creation of institutions. Following North (North 1990: 3) "[institutions] are the rules of the game in a society or, more formally, are the humanly devised constraints that shape human interaction". Institutions can fulfill their ordering function because they are stable; they "[..] reduce uncertainty by providing a structure to everyday life" (North 1990: 3). Importantly for this study of violence regulation in weak states, North's definition encompasses informal institutions. Comparative politics has strongly favored the study of formal institutions over informal ones. While such a bias might have few distorting effects for the study of highly bureaucratized OECD politics, such an approach fails to grasp the workings of many weak states in which informal institutions dominate politics (Bratton 2007: 9697). In the context of state formation, it is clear that prior to the establishment of formal state institutions there must be informal institutions in place.

By institutionalizing the control over means of violence, the power that flows from violence and coercion is stabilized. These stable power relations thus take on the form of political rule and, when they are perceived as legitimate, authority (Weber 1972). They provide both the ruler and the ruled with certainty about the exercise of violence as it is clear who controls means of violence and under what conditions these means are applied. By doing so, they structure the distribution of a great amount of political power among societal actors. However, the institutional stability that makes the use of force predictable also makes change even more difficult than in non-violence related institutions. Most institutional change in politics occurs ei ther incrementally over longer periods, or through exogenous shocks. Consequently, institutions do not always reflect optimal solutions to social problems, but rather the distribution of powers among those actors who create and reproduce them (Pierson 2004: 44-48). Institutions that regulate violence

\footnotetext{
${ }^{13}$ My own translation from German.
} 
create a strong lock-in effect. What distinguishes institutions of violence regulation from other institutions is that in order to tame violence, they need to have the capacity to apply violence (Popitz 2004: 62-64). Therefore, changing these institutions is very difficult for actors who do not have access to means of violence.

To be clear, violence regulation is not the only foundation of social order and political rule: It is a necessary condition, not a sufficient one. Other aspects of the social such as the distribution of wealth or control over symbolic meanings also have strong ordering effects (Earle 1997: 6-10 ; Elias 1983). Nevertheless, the regulation of violence is at the heart of all political order.

\section{Statehood as an Institution of Violence Regulation}

The state is the most important political institution of contemporary world society (Schlichte 2005a: 62-63). In many ways, states are defined by the fact that they are expected to regulate violence (Migdal and Schlichte 2005: 15-16). Theories of political coercion and actual state practice developed hand-in-hand, and theories that see the state as the most important regulator of violence date back to early modern philosophers like Bodin and Hobbes (Krasner 2001: 20). Perhaps the most famous justification for the need to regulate violence by concentrating it in the hands of a sovereign is Hobbes' claim that otherwise man's life would be "[... solitary, poor, nasty, brutish, and short" (Hobbes 1991). Today's conception of the state is strongly influenced by the works of Max Weber. According to Weber, although a state can perform all kinds of functions, what distinguishes it from other organizations is its ability to claim a monopoly on the legitimate use of force (Weber 1972: 29-30). He therefore defined the state as "[..] a human community that (successfully) claims the monopoly of the legitimate use of physical force within a given territory". The state is an institutional solution to the problem of violence regulation. In order to fulfill this function, modern states have developed armies and police forces as organizations that have means of violence at their disposal. While armies defend the state against both other states as well as armed uprisings, the police enforces law at the level of individual citizens.

If the goal of violence regulation is to reduce the occurrence of violence, the modern state has been a highly successful institution. Historically, the increased monopolization of means of 
coercion in the hands of governments has been accompanied by a drastic reduction in societal violence (Pinker 2011). Within European societies, the incidents of homicide have drastically dropped during the process. Eisner shows that between the $13^{\text {th }}$ century and the early 1990 s, homicide rates per 100,000 inhabitants have decreased in England from 23 to 1.2, in the Netherlands and Belgium from 47 to 1.2, and in Germany and Switzerland from 37 to 1.2 (Eisner 2001). Violence has become a rare phenomenon in the developed state, and when it occurs it generates massive outrage. The state in the developed world has disarmed its competitors as well as (to a certain extent) its citizens, and it has also largely delegitimized the private use of violence. Internationally, the record is mixed. The state has initially created some of the most deadly wars in human history. However, since World War Two, the ever increasing destructive potential of states has not translated into increased global violence. For several decades now inter-state war has been in decline and large-scale violence erupts mostly where the state is weak or absent (Fearon 2004; Fearon and Laitin 2003; Sarkees et al. 2003). The strongest reduction of inter-state war has been achieved through the combination of statehood with democratic regimes. Peace between democratic states has become a law-like regularity in international politics (Dafoe 2011). Nevertheless, the monopoly on violence has enabled states to both wage some of the most brutal wars in human history as well as massive violence against its own citizens. The German genocide of the European Jews is but the starkest example of what states can do to (parts of) their populations with their coercive capacities. Given the immense capacity of monopolists of violence to harm their own citizens, how did developed states tame their governments?

The access to control over means of violence needs to be regulated, and the exercise of state violence needs to be constrained. One source of recurring instability for states is the lack of a non-violent mechanism to dispose of incompetent rulers. States with a monopoly on violence might be stable for decades, but if the government is not responsive to popular dissatisfaction, civil war is a likely outcome. The disposition of government through elections has evolved as the default option in developed states and thereby mostly resolved the problem of large-scale internal violence (Przeworski 1991). In contrast, protection against government violence is a constant political struggle, but has been greatly furthered through the rule of law. Through institutions that create checks and balances, or veto points, state repression has been tamed in Western democracies. All of these regulations of state violence are, however, secondary to the establishment of a monopoly on violence. Where political parties are also armed groups, 
accepting electoral defeat is dangerous for each actor and the resulting lack of trust will undermine democracy. Where people have the choice between different organizations of rule enforcement, the rule of law will not work properly. The monopoly on violence is the necessary condition for both democracy and the rule of law (Møller and Skaaning 2011).

If a monopoly on violence can reduce outbreaks of violence and if it can also enable polities to develop democracy and the rule of law, one could expect it to be a highly successful model on the global level. Indeed Weber's ideal type has shaped global expectations of what a state should look like (Migdal and Schlichte 2005). However, even this most basic feature of statehood seems to be missing in many sovereign states. A great number of internationally recognized states have either a weak monopoly on violence or none at all. These entities have received labels such as quasi-states or failed states (Jackson 1993). As the Bertelsmann Transformation Index (BTI 2014a) dataset shows, in 2014 only half of the 129 countries in transformation had a full monopoly on violence ${ }^{14}$. About $42 \%$ had a partial monopoly, while ten countries had no monopoly on violence at all (see table 4 ).

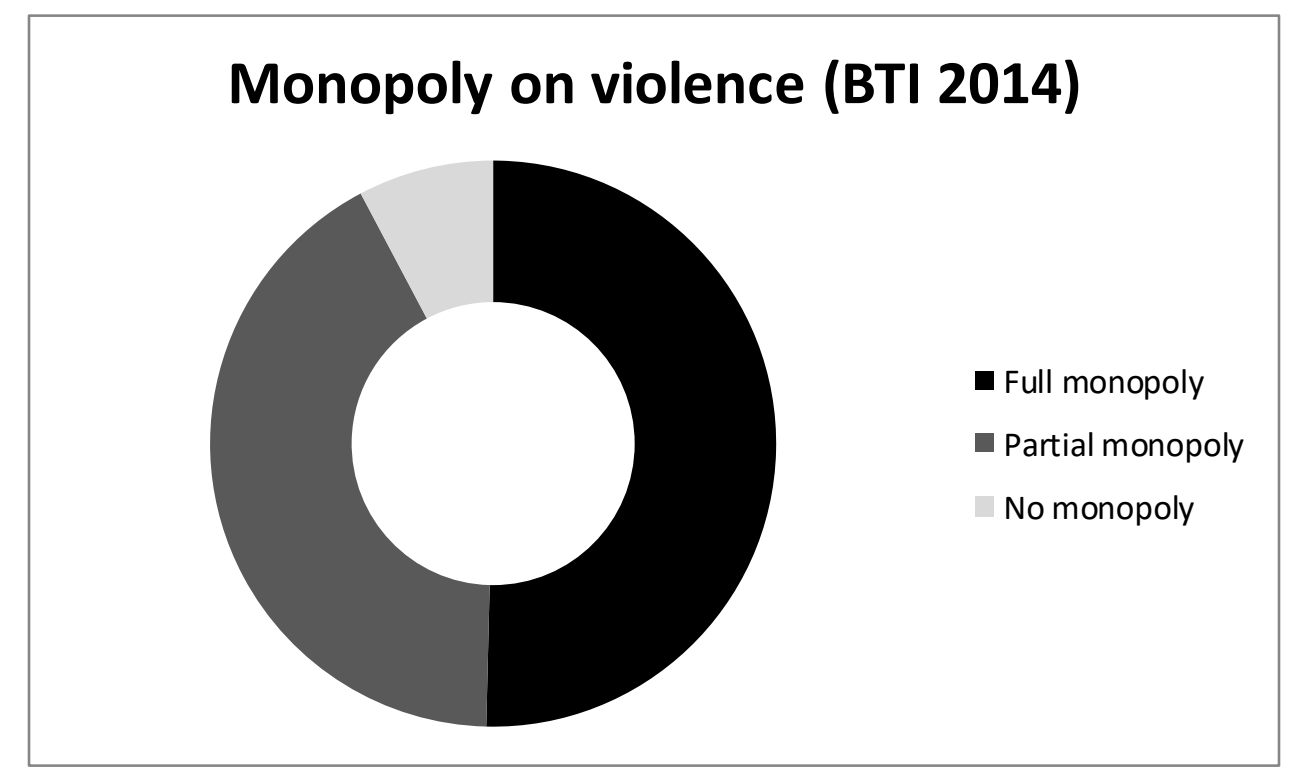

Table 4: "Monopoly on Violence" score of 129 countries in transition (BTI 2014a).

\footnotetext{
${ }^{14}$ The scale ranges from 1 to 10 . I coded 8 and above as a full monopoly on violence, 3 and less as no monopoly on violence, and everything in between as a partial monopoly on violence.
} 
While such data is helpful to get an idea of broader global trends, it remains unclear what exactly a monopoly on violence entails. For example, to my knowledge the BTI data is the only data set that actually has a 'monopoly on violence' variable. Its coding is based on how much of the state's territory is controlled by armed actors, ranging from rebels to organized crime (BTI 2014a). However, many more constellations are conceivable in which the state regul ates violence to different degrees. A government could be the only actor who controls means of warfare, while all other forms of violence might be controlled by non-state actors. In a more strict definition, a state would actually have to monopolize violence at all societal levels. Here, many questions do arise: Does it affect the monopoly on violence if individuals are allowed to own guns? Does it matter whether there is organized crime on the territory of the state? What does the federalization of policing tell us about the state's monopoly on violence?

\section{Regulating violence, large and small..}

In order to clarify the concept of monopoly on violence, I propose to distinguish between two forms of violence: Large-scale and small-scale violence (cf. Giustozzi and Isaqzadeh 2013: 2-3). A state with a monopoly on violence regulates both types of violence. Large-scale violence is organized violence, i.e. any type of warfare. Hence, a government with a monopoly on largescale violence is the only actor on the territory of the state that controls organizations capable of waging war (i.e. armed forces). In contrast, small-scale violence is the everyday inter-personal violence that ranges from domestic violence to rule enforcement. Governments have the monopoly on the regulation of small-scale violence when the state is the only actor to make and enforce collectively binding rules. Table 5 and table 6 provide overviews of the actors and institutions that typically regulate violence. 


\begin{tabular}{lll}
\hline Actors & State & Non-State \\
& & \\
\hline Large-Scale Violence & Government & Armed Groups \\
& (Military) & (Rebels, Warlord Polities, etc.) \\
Small-Scale Violence & Government & Local Elites \\
& (Police) & (Tribal Leaders, Elders, \\
& & Chiefs, etc.) \\
\hline
\end{tabular}

Table 5: Actors of large-scale and small-scale violence regulation.

\begin{tabular}{lll}
\hline Institution & State & Non-State \\
& & \\
\hline Large-Scale Violence & Regional Statehood & Empire, City State, City \\
& (Monopoly on warfare in & League \\
& clearly delimited territory) & \\
Small-Scale Violence & Bureaucracy & Self-Help Community \\
& (Legal framework, local & (Chiefdoms, Tribes, Villages, \\
& administration) & etc.)
\end{tabular}

Table 6: Institutions of large-scale and small-scale violence regulation.

The analytical distinction of these two kinds of violence is empirically reflected by the historical development of modern states in Europe. In the first centuries of monopolization, governments have centralized the means of warfare. The organizational tool to achieve this was the standing army. After this process was largely completed around 1800, states have monopolized the regulation of small-scale violence in the hands of another organizational innovation: Modern police forces. In Europe, this process was only completed in the $20^{\text {th }}$ century, when local elites were deprived of their last privileges to use force against their constituent populations (Tilly 1985: 173-175 ; 1992: 25). Having established the distinction between large-scale violence and small-scale violence, the next two sections will discuss the two forms of violence and their regulation through institutions in detail. 


\subsection{Regulating Large-Scale Violence}

This section provides a theoretical discussion of the regulation of large-scale violence. It presents the institutions and actors of large-scale violence, and briefly summarizes historical trends of monopolization. Subsequently I examine the state formation literature to find existing explanations for the rise of the state as a monopolist on large-scale violence. The section concludes by arguing that the modern state has developed as a regional institution of large-scale violence regulation.

Large-scale violence denotes organized violence between at least two groups. It encompasses all types of war including inter-state war and civil war. Large-scale violence is not simply the result of a large number of individuals coordinating their actions in order to harm another group. In order to exercise large-scale violence effectively, it takes organizational capacities (Malešević 2010: 4-7). Hence, the regulation of large-scale violence is always a regulation of armed organizations. Whether they are armies or rebel groups, armed organizations usually have a leadership, a certain hierarchy, and a (however loosely) defined membership (Lichbach 1998: 17 ; Schlichte 2009). Sustaining these types of organizations is very resource-intensive. Soldiers need to be fed, equipped, supplied with ammunition and fuel, and taken care of when they get injured (Hazen 2013: 22). At the same time, armed organizations absorb large numbers of young men (and increasingly women) who would otherwise be involved in productive economic activities (Levy and Thompson 2010: 1). Overall, the establishment and maintenance of means of large-scale violence is very costly; but it can pay off.

Regulating large-scale violence offers great rewards for the elites who control armed forces as well as for society as a whole. The regulation of large-scale violence usually entails either a monopolization of the means of warfare, or power-sharing arrangements in which elites refrain from making use of their violent capacities (North et al. 2009: 59-61). In Olson's (1993: 568) famous formulation, those who control the means of warfare become 'stationary bandits'. Political actors who control the means of coercion in a certain area will extract resources from the population (Tilly 1992: 70-71). While the population is subjected to taxation and sometimes military service, the security generated by those who control the means of warfare makes 
investment into a social order worthwhile for individuals (Lake 2010b). Thus, the establishment of a basic social order enhances both security and welfare, thereby generating benefits both for the elites as well as the population (Olson 1993: 567-570). This constellation is nevertheless one of power asymmetry where elites rule over a population not because of mutual consent or some prior social contract, but simply because they have the means to do so. There are several ways in which the control over the means of large-scale violence can be institutionalized, and the state has historically proven to be the most successful one.

\section{Institutions of Large-Scale Violence Regulation: The State and its Alternatives}

Statehood has become the dominant institution that regulates large-scale violence in society. Large-scale violence is regulated in modern states through a complete monopolization of the means of warfare by the government within a clearly delimited territory. It has accumulated an unprecedented capacity to exercise large-scale violence through the establishment of standing armies, but only its territoriality has enabled the state to monopolize the means of large-scale violence. A monopoly on violence only makes sense if it is spatially delimited. Thus, the monopolization of the means of warfare necessitated clearly defined borders. This combination of clearly defined territory and a monopoly on warfare distinguishes states from other historical forms of large-scale violence regulation.

Prior to the emergence of the modern state, there was a variety of political orders that regulated large-scale violence. These included city states, city leagues, and empires, all of which had multiple actors who controlled the means of violence and/or lacked clearly defined borders (Ruggie 1993: 149-152 ; Spruyt 1994: 3-5). One of the most complex arrangements is arguably medieval Europe, where means of large-scale violence were controlled by the Empire, by kings, by dukes, and by the church in overlapping jurisdictions. Often times, elites did claim rule over a set of people instead of ruling within a certain territory (Spruyt 1994: 36-41). Other imperial orders such as the Chinese or Roman Empire were comparable to concentric circles of large-scale violence control. In these cases, there were no clear boundaries of empire but rather different frontiers and zones of control (Giddens 1985). What all empires had in common was their claim of universality; there were not two neighboring empires with clearly defined borders. Empires show that statehood is not the only viable answer to the problem of large-scale violence 
regulation. The great achievements of the Roman and Chinese Empires in terms of economic and cultural development are a case in point. In the contemporary international system, quasi-imperial orderings still exist where governments of powerful states do not accept the borders of their weaker neighbors, but transgress the borders to establish further zones of control.

While many states in current world society strive for a monopoly on large-scale violence, they often fail to achieve it. Their borders are formally fixed, but internally the government lacks the organizational capacity to monopolize means of warfare (Jackson 1993). In these cases, other actors also possess the means of large-scale violence. These armed groups can use their warfare capacities for varying goals. They can fight for control over the state, or they can strive for secession from the state. In such cases of civil war, large-scale violence regulation occurs only in zones exclusively controlled by one party of the conflict (Kalyvas 2008). Some armed groups might not strive for monopolization but rather seek power-sharing arrangements with the government, or they want to control a certain area and extract resources from the population (Staniland 2012: 253-254). Such orders could be described as oligopolies of violence. Given the incentives to resist central government's efforts to monopolize the use of force, the next sections will deal with the question of how and why the state could triumph over its competitors.

\section{Actors of Large-Scale Violence: Organizing Means of Warfare}

For statebuilders, the process of monopolizing the means of large-scale violence is mainly an exercise in organizational capacity-building. Government needs to build armed forces, and it needs to disarm competitors. The key challenge with regard to the creation of a strong army is to fund the expensive organization. Taxing the population to extract the necessary resources has historically been one of the main challenges for rulers because too much 'resource extraction' could cripple the economic foundations of their realm (Olson 1993). In contemporary world society, these problems are still present but have been greatly reduced due to two contextual changes. First, the world market allows many governments to sell natural resources and use the revenues to fund their armed forces. Second, there are many international sources of funding from military assistance by Great Powers (e.g. the US Counterterrorism Partnership Fund) to multilateral development assistance (e.g. through UN institutions). While these sources have made it easier for central governments to build security forces, they have also decoupled 
governments from their populations (Bliesemann de Guevara 2012; Ross 1999). Whatever their source of funding is, more resources make it easier to build means of large-scale violence. However, the same is true for any non-state actor controlling means of warfare. Armed non-state actors, or armed groups, have been able to capitalize on economic globalization. Access to global markets allows them to fund their activities by selling the same resources as the governments they fight (Le Billon 2001). Furthermore, these groups can make profits from drug trafficking or human trafficking (Ross 2004). World markets also offer the possibility to buy arms, although most armed groups are only able to acquire small arms. Many armed groups have received support from states that had an interest in disposing the incumbent government (Gleditsch 2007; Salehyan 2007).

The stronger the central government becomes, the better is its bargaining position vis -àvis competitors. Armed groups competing with the government can be either co-opted or defeated (Tilly 1992: 84). Given the possibility that warlords or rebel groups can form alliances against the central government, monopolization efforts always pose risks for the ruler (Migdal 1988: 24-32). "States and insurgents are not simple-minded maximizers of monopoly but instead are optimizers of authority in complex, often counterintuitive, interaction with other armed actors" (Staniland 2012: 244). As a result, state formation is a rather discontinuous, step-wise process in which periods of rapid monopolization can alternate with longer periods of accommodative strategies towards internal competitors.

Monopolies on large-scale violence can be volatile arrangements. Even if they have lasted for decades, they can collapse within weeks. It is easy to imagine how a monopoly on violence can crumble once opposition groups manage to form hierarchical organizations and acquire weapons. However, not only can armed challengers appear quickly, governments can also defeat them in surprisingly short time periods. A monopoly on large-scale violence disappears when opponents of the existing order manage to create an armed group, i.e. when they establish the organizational means of large-scale violence. Setting up such an organization within an existing state is difficult, but once the armed group is established it can become very durable. Figure 3 shows the monopoly scores of two extreme examples, Syria and Sri Lanka. In Syria, protests that were sparked after the Arab Spring Movement emerged across Arab states were countered with brute force by the ruling regime in 2011. As a consequence, the movement radicalized and turned into an insurgency. The resulting civil war has devastated vast parts of the country, leaving the 
government with a small zone of control while various rebel groups have their own territories. At least two areas, the Sunni dominated East (controlled by the armed group Islamic State) and the Kurdish North now even threaten the territorial integrity of Syria (TheEconomist 2014). Thus, a seemingly stable state monopoly on violence has fallen apart within months. In contrast, the Sri Lankan government has established a nearly complete monopoly on violence. After decades of civil war, in which the LTTE rebels build a shadow government in their areas of control, the state resorted to massive violence in 2009. Although the military actions led to horrendous casualties among the civilian population, the outcome was the total defeat of the rebel movement and the monopolization of coercive means by the central government (Pinney 2014). As these examples show, monopolization processes can be extremely violent, and the state monopoly on large-scale violence itself is a volatile constellation that needs other institutional features to stabilize.

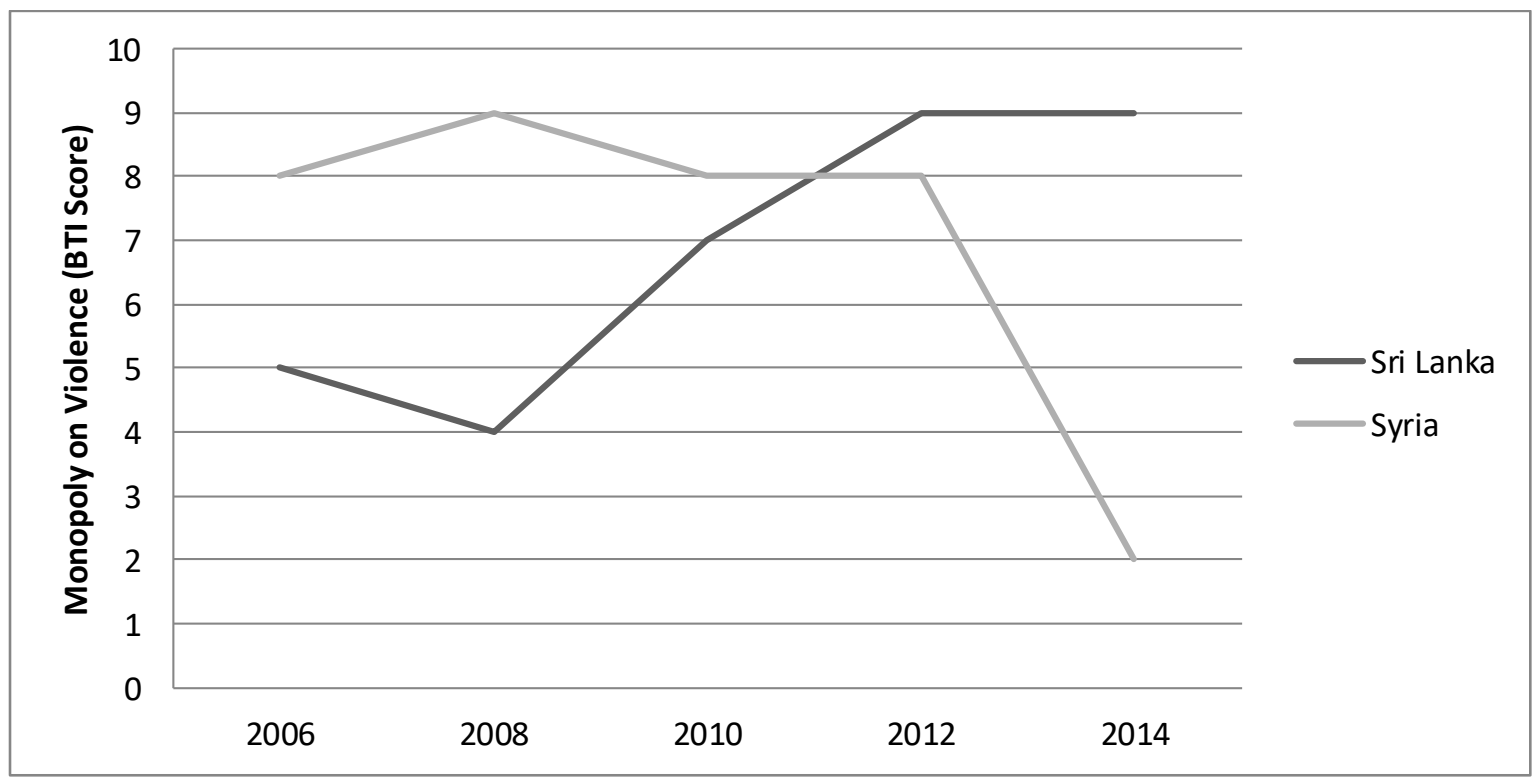

Figure 3: Monopoly on violence in Sri Lanka and Syria.

\section{The Process of Monopolizing Large-Scale Violence: A brief history}

There have been many historical attempts at accumulating the means of large-scale violence, but only early modern Europe eventually experienced the emergence of the modern state system. Prior to the Neolithic Revolution, humans lived in groups too small to sustain a class of people 
solely concerned with coercion. However, with the economic surplus produced through agriculture, elites could tax these surpluses and pay specialists for violence. There are two world regions in which monopolies on large-scale violence have endogenously emerged in history: China of the Warring States Era and Early Modern Europe. In China, the process of state formation ended with the victory of one unit over the others, eventually leading to a reemergence of an imperial order. In Europe, statehood was institutionalized.

In China during the Warring States period ( $5^{\text {th }}$ century $\mathrm{BC}$ ), several political units have developed the trademarks of statehood. As Hui (2005: 3) notes, the regional system consisted of "[..] sovereign territorial states [..]". They monopolized the means of large-scale violence, introduced conscription, and effectively taxed the population (Hui 2005: 180-184). Armed forces were expanded to the size of several hundred thousand soldiers, and the organization of largescale violence became more complex and bureaucratic. Especially the entity of Qin developed to an astonishing level of statehood. However, Qin succeeded in defeating the other states and unified China under one empire (Hui 2005: 170-177). Therefore, in China the state disappeared after a few hundred years of state formation.

In Europe, the monopolization of large-scale violence was more sustainable. The region's feudal order was highly fragmented, but this began to change at around $1500 \mathrm{AD}$. Certain rulers succeeded in slowly and steadily defeating their 'internal' competitors while also incorporating an increasing number of formerly independent dominions. In France, the king was initially a primus inter pares. However, since the $15 \mathrm{~h}$ century the central government started to systematically weaken the nobility of the Estates General. Local elites were either inc orporated into the central government ('the court') or defeated. Thus, by the late $17^{\text {th }}$ century the French monarchy had become 'absolute' (Ertman 1997: 125-139). Whereas France was the statebuilding entrepreneur, others followed suit. The British crown relied on mobilizing its nobility in times of war until the $17^{\text {th }}$ century. Then, in 1661 , it created a standing army for the first time, thereby beginning to monopolize large-scale violence (Ertman 1997: 187-207). As a third European example, Prussia managed to achieve a monopoly on large-scale violence around 1700. Despite being a rather poor and rural state, the Prussians effectively extracted resources and built armed forces. Thus, "[in] 1786, it was the thirteenth largest European state in population and the tenth largest in area, yet boasted the third largest army. With a population of 5.8 million, Prussia sustained an army of 195,000" (Clark 2007: 215). These processes of accumulation and the 
diffusion of innovations in organizing large-scale violence were mostly finished around 1800, when Europe consisted of states with clearly defined borders and governments that had completely monopolized the means of large-scale violence. During the $20^{\text {th }}$ century, this European model of statehood has developed into a global norm: The Correlates of War data set (CoW 2011) counts 42 states in 1900, whereas there were 195 states in 2011. Until 2014, South Sudan has joined the club of recognized states, and several entities such as Kurdistan in Iraq or Somaliland in Somalia had developed de facto state capabilities.

\section{State Formation Theory and Large-Scale Violence}

If the state has become a globally accepted model of large-scale violence regulation, then what are the conditions under which states could emerge? State formation scholars have developed two seemingly competing explanations: Some have argued that the state is the result of competition and warfare, while others see it as the result of cooperation. I argue that these approaches are complementary as both competition and cooperation were crucial for the development of states. In contrast, classical European state theory which has focused on the relation between rulers and ruled fails to explain the process of large-scale violence monopolization. It posited that the rules of state authority need to be established between elites who control the means of violence, and the population which is being disarmed. The people trade in their ability to use violence against the protection by the elites. Thus, a social contract is concluded that is based on reciprocity and mutual consent (Haldén 2013: 35-37 ; Olson 1993: 568-569). However, scholars of state formation have time and again pointed out that this contract has empirically never been concluded. They show that actors who were best at organizing violence became the rulers over a population (Olson 1993: 568). Only thereafter did the relation between the ruler and the population change as the subjects demanded citizen rights in return for ever increasing taxation and state interference with their lives (Tilly 1992: 115). The original institutionalization of statecontrol over large-scale violence thus has preceded the 'bargaining' between government and population.

The literature on state formation has offered several explanations for the emergence of states with monopolies on large-scale violence. While they all focus on certain explanatory variables, they are also mostly compatible with each other. The classical monopolization 
mechanism has been drawn out by scholars such as Hintze (1906) and Elias (1939[2000]). In its most abstract version, rulers of political entities are in security competition with each other and each fears being eliminated by the others through war. Thus, the rulers begin building stronger armed forces and defeat 'internal' opponents. The theory has been further specified and popularized by Tilly, who put greater emphasis on the capability of states to extract resources from its population and, thereby, fund an ever more sophisticated war machinery (Tilly 1975, 1985, 1992). Tilly (1975) famously remarked: "War made the state, and the state made war". Several scholars have built on this war-centric explanation to show that a lack of inter-state competition has caused state weakness in Latin America and Africa (Centeno 2002; Herbst 2000; Thies 2005). Hui could show that the same mechanism was at work in ancient China. However, in China the competition ended when one state defeated all others. Thus, the re-establishment of Empire eventually ended this period of state formation (Hui 2005). Later, these explanations were amended as to explain why the competition has created different types of states, for example by highlighting the impact of pre-state institutions on the capacities of states (Ertman 1997).

Other authors have challenged the purely competition-based approach to state formation. They tried to show that constant warfare did not suffice to make the state. Instead, statehood itself is a set of rules that had to be accepted by those actors who controlled means of large-scale violence (Ruggie 1993; Spruyt 1994; Thomson 1995). Some authors have highlighted the importance of new social alliances between internal elites, in particular between central government and a bourgeoisie class that was spawned by capitalist development (Hechter and Brustein 1980; Spruyt 1994). However, arguably the most important elite cooperation has been the one between those actors who controlled the means of large-scale violence. Scholars of International Relations have shown that state formation had a strong regional dimension. The core elements of statehood (territoriality, control over means of warfare, law making) were combined in the legal norm of sovereignty (Thomson 1995), which emerged through a string of international treaties that are frequently cited by IR scholars as hallmarks of the international system: Augsburg 1555, Westphalian Peace 1648, Peace of Utrecht 1713, and the Vienna Congress 1815 (Ruggie 1993). "If institutions are defined as 'persistent and connected sets of rules, formal and informal, that prescribe behavioural roles, constrain activity, and shape expectations' then sovereignty is an institution" (Sørensen 1999: 591). Furthermore, as Spruyt (1994: 6-7) has pointed out, the state enabled European political elites to credibly commit to 
agreements because each ruler knew that the others ruled over a similar political system in which they were the final authority.

To sum up, state formation was driven by several factors: War, capitalism, social alliances, and regional developments. However, the two key features of state formation are the military capacities of political elites and the regional consensus on statehood as an institution. These two elements, organizations (governments, armies) and institutions (sovereignty, international law), are of central importance to understand the emergence and stability of statehood as the dominant form of large-scale violence regulation.

\section{Conclusion: Statehood as a Regional Institution}

What connects both competitive and cooperative approaches to state formation is their systemic dimension (Haldén 2013). States have not developed in isolation but as part of a broader European state system. Every accumulation of means of warfare could always threaten other political entities, and a lack of clear delimitation of these entities exacerbated this security dilemma. Without rules that regulate who is allowed to control means of large-scale violence, and where these means can be deployed, the order is likely to either fragment again or lead to imperial accumulation processes (Hui 2005).

Thus, in order to explain the creation of monopolies on large-scale violence it is not sufficient to focus on the organizational capacities of governments, although they are a necessary condition for statehood. Only the establishment of territoriality transforms a strong coercive capability into a monopoly on large-scale violence because the zones of control need to be clearly specified through borders. In other words, statehood is a regional institution in which a multitude of spatially separated monopolies on large-scale violence exist. If institutions are defined as the rules of the game, then what is the game in the case of statehood? The rules governing the existence of states as monopolists of large-scale violence need to be accepted by the political elites of a region. It is elites who control the means of large-scale violence, and only their consensus makes statehood work as an institution. There needs to be a general agreement among regional elites on the principle of territoriality so that states can be clearly distinguished from each other. There also needs to be a norm that the means of large-scale violence can only be 
legitimately controlled by state governments, whereas armed non-state actors are not legitimate participants in regional politics. Armed groups or individual governments may deviate from the norm, but as long as most key actors (regional hegemons, governments) are committed to a system of sovereign states, it can be seen as institutionalized. The need to have a basic agreement over the type of political entity that is allowed to control means of large-scale violence (i.e. the state), and the shared basic rules of interaction (i.e. norms and international law) have led some scholars to argue that what evolved in Europe was not just an international system but an international society (Bull 2002: 31-36).

Does this mean that governments do not need to be legitimate in the eyes of the population? Tilly has argued that for the establishment of a monopoly on large-scale violence, the source of legitimacy is not primarily the population but that "[legitimacy] is the probability that other authorities will act to confirm the decisions of a given authority" (Tilly 1985: 171). However, while regional acceptance is an important source of legitimacy, reducing it to this elite consensus would take the argument too far. Nevertheless, when combined with the basic legitimacy that governments receive from the population for ending large-scale violence, i.e. providing a minimum of security, the regional institutionalization is a strong source of a government's authority (Lake 2010b: 36-39 ; Trotha 2000: 260). Therefore, statehood as the regional institution of large-scale violence regulation is based on an elite consensus where powerful actors agree on the unit and its basic polity characteristics.

\subsection{Regulating Small-Scale Violence}

This section argues that small-scale violence regulation is either conducted by the state or by selfhelp communities. I will discuss both of these institutional arrangements as well as important actors of small-scale violence regulation in detail. Afterwards, I provide an overview of the historical monopolization process that has led to a state monopoly on small-scale violence regulation and investigate which explanations have been offered for this phenomenon. Eventually, I show that while a monopoly on small-scale violence regulation is highly beneficial for governments, the process of monopolization is very risky. As a result, many states accept the existence of self-help communities and cooperate with local non-state elites. Before going into 
the details of institutions, actors and processes, the following paragraphs explicate the concept of small-scale violence.

Small-scale violence is violence at the individual level. It can entail criminal violence as well as the use of violence to enforce rules. All societies in human history had to manage the potential of people to harm their fellow human beings (Trotha 1995: 131). Definitions of what constitutes criminal acts of violence vary across societies. Domestic violence might be accepted by many societies while murder is accepted almost nowhere. As most people put a high value to being secure from other people's violence, they have sought ways to regulate these instances of small-scale violence. The result of this search for stability are institutions that included rules that prohibited certain types of inter-personal violence as well as enforcement mechanisms that would deter others from deviant behavior. With these institutions emerged elites that would interpret the rules, judge whether individuals had breached the law, and who would ultimately control means to punish deviant behavior. In contrast to large-scale violence, small-scale violence regulation does not depend on a single large and expensive organization. Instead, it requires a more constant process of policing, i.e. of "[..] the creation of systems of surveillance coupled with the threat of sanctions for discovered deviance - either immediately or by initiating penal processes" (Reiner 2010: 5). Put differently, small-scale violence regulation requires knowledge about the community in which it operates as punishment for deviant behavior needs to be applied to individuals. As Kalyvas points out, the effectiveness of coercion against individuals depends on its selectivity. Indiscriminate violence fails to ensure compliance. In order to apply violence selectively, the ruler needs information about the population (Kalyvas 2008). Thus, there is a strong bottom-up element in small-scale violence institutions as the communities have to accept the rules and the authority claims of elites in order to make the institutions effective.

The institutions and organizations that regulate large-scale violence cannot effectively regulate small-scale violence. Armed forces are not effective in monitoring the population as they are usually hierarchical organizations with weak ties into local communities, and their use of force is most likely disproportional. Civil wars in which armed forces have resorted to the collective punishment of villages in response to the attacks of individual insurge nts are a case in point. Instead of achieving their aims, those who use force indiscriminately produce (armed) resistance against their arbitrariness (Kalyvas 2008; Schlichte 2009). Thus, although standing armies were for a long time a tool of domestic order, they have been incrementally 
complemented, and eventually replaced, by police forces (Giddens 1985). The next section will discuss the institutions that regulate small-scale violence. The regulation of small-scale violence always entails institutions that set and enforce rules. Two basic forms of regulating institutions have emerged historically: Self-help communities and states (Trotha 1995: 131).

\section{Institutions of small-scale violence regulation: Community or State?}

\section{Self-Help Communities}

Self-help communities are social units that regulate small-scale violence among its members by setting rules and enforcing them. Self-help communities can take the form of villages, clans, chieftaincies, or similar small units (Elias 1978: 151 ; Gerdes 2013a: 14-15). While it is common to characterize these institutions as 'traditional' or 'kind-based', these attributes are not necessary for a self-help community to exist (Khoury and Kostiner 1990: 5-6). What they convey, however, is that the evolution of such an institutions takes time. Nevertheless, many of the so-called traditional institutions such as African chiefdoms have only been created by the colonial powers (Trotha 1996: 80-82). Accordingly, the rules regulating small-scale violence can be codified or informal, and their source can be religion as well as custom; however, their source is not the constitutional order of the state. Whatever their source, rules need to be enforced in order to be effective. Hence, every institutional setting has its elites which judge whether individuals have violated the rules, and these elites also control the means to punish misbehavior. Elites of selfhelp communities can become very powerful, as the community is usually based on personal relations. "The term personal relations designates a structuring principles characterized by social organization around persons or personified forces [..]" (Gerdes 2013a: 15). Over time, these institutions can become deeply entrenched as the population internalizes the rules, and successful elites can become strong authorities. The legitimacy of these local institutions is not of a legalrational character. Instead, they derive basic legitimacy from the provision of everyday order. Further, these relations of authority are stabilized by legitimacy derived either from tradition or from the charismatic leadership of local elites. For example, Pashtun tribal leaders in Afghanistan's East can invoke the centuries-old Pashtunwali codex as a traditional source of their

legitimacy. In contrast, mujahedin commanders that came to power in North Afghan 
communities during the 1980 s often times base their rule more on coercion, but at the same time their history of fighting infidels (both Soviets and ISAF) can bestow them charismatic legitimacy.

States have become the globally dominant form of political order. Thus, local institutions that regulate violence will do so in a context of (weak) statehood. In many rural regions of the developing countries, self-help communities remain the dominant (or even sole) regulator of small-scale violence (Trotha 1996: 90-91). Where the government has a monopoly on large-scale violence, self-help communities can be either be ignored, co-opted, or suppressed by the state. Khoury and Kostiner note that "[..] as their level of stateness changes over time, states accommodate tribes in varying degrees of social integration and political participation" (Khoury and Kostiner 1990: 7). Local elites can exert power over the center by threatening to form alliances against the government. Indeed, many self-help communities form political platforms to further their interests. For example, in Afghanistan the former mujahedin parties and the Pashtun meta-tribes fulfill the function of connecting the local elites to the center. These 'neopatrimonial' networks may entail all sorts of exchanges, but at the heart of the matter is a basic deal: Local elites are granted autonomy, the right to use small-scale violence, and to tax the population. In return, they deliver stability to the central government by staying loyal and keeping in check potential rivals of the central government. As De Waal (De Waal 2009: 103-104) notes: "Provincial elite members seek to maximize the price they can obtain for their loyalty from metropolitan elites (mostly governments). They do this using the tools at their disposal, which include votes, extending or withdrawing economic cooperation, and the use of violence". Police forces do exist in these countries, but they are scant outside the major urban agglomerations and co-exist with self-help communities. The simultaneity of self-help community and state generates a situation of legal pluralism in which great parts of the population can choose between different legal systems (Merry 1988: 875-882).

Where the government has no monopoly on large-scale violence, self-help communities often times have to guarantee the security of their members in a context of armed conflict. In civil wars, governments and armed groups often try to secure their gains by arming loyal self-help communities (Ahram 2011: 8-11). However, it is also possible that a number of self-help communities join forces to overthrow a government, thereby transforming themselves into an armed group. One of the most recent examples of this phenomenon is the Tehrik-e Taliban (TTP) 
in Pakistan, which was created in 2007 as "[..] an umbrella organization of dozens of Taliban groups throughout Pakistan [..]” (Mahsud 2013: 169).

\section{State Order}

In contrast, state-centered orders of violence are characterized by a monopoly on small-scale violence and legal monism. Small-scale violence is regulated through agencies such as bureaucracies, courts, and, most importantly, police. The rules that govern society are state law, while customary rules or religious law are either abandoned or integrated into the legal framew ork of the state (Griffiths 1986: 2). State-centered orders usually expand their claims to regulate inter-personal violence into all areas of life (Trotha 1995: 133-134). While the state can delegate the means of coercion to non-state actors, for example private security contractors, it reserves itself the right to withdraw these privileges at any time. The most important element of state regulation of small-scale violence is state policing. "The distinctiveness of the police lies not in their performance of a specific social function, but in being the specialist repositories for the state's monopolization of legitimate force in its territory" (Reiner 2010: 8). Modern police are highly specialized organizations that embody the state monopoly on violence at the local level. Unlike soldiers in armed forces, even the lowest ranking police officers need a comparably high level of skills as they often act with a high degree of discretion. As Marenin (1982) has argued, policing always entails "parking tickets and class repression." A well-functioning police provides security, but it also always stabilizes the political regime of a country. Where the government is still weak and struggles to control local populations through policing only, they have developed gendarmerie or paramilitary police organizations (Giustozzi 2011a: 9-10). Despite the often invoked strict separation of the tasks of armies and police forces, these organizations work at the intersection of small-scale violence and large-scale violence regulation.

For central governments, the benefits of regulating small-scale violence are immense. Once the state controls violence at the local level, it can implement its rules instead of tolerating legal pluralism. When its local competitors are gone, the state can exercise what Mann (Mann 1984: 189) has called infrastructural power: "[..] the capacity of the state to actually penetrate civil society, and to implement logistically political decisions throughout the realm". The greatest payoff in terms of actual violence is the ability of the state to replace local elites that could 
organize rebellions, to constantly monitor local communities, and to act preventively to maintain order (Tilly 1992: 114-115). Direct rule over the population also improves the state's capacity for taxation (Gerring et al. 2011: 383-384). However, as a brief discussion of the relevant actors shows, monopolizing small-scale violence is a risky endeavor for governments.

\section{Actors of Small-Scale Violence Regulation}

Every institutional setting produces elites that have privileged access to resources, better information about the rules, and sometimes even the possibility to foster or block institutional change. This power differential is even greater in institutions that regulate violence, as they always have an enforcement component. In the case of small-scale violence regulation, the main actors are the government of the state, and the elites of local self-help communities.

Local elites can occupy a wide range of specific positions within their institutional settings. In early modern Europe, these actors were the landed nobility that ruled over the countryside of the absolutist state. Today, local elites are chiefs in chiefdoms, elders in village communities, tribal leaders in tribes, 'commanders' in smaller warlord polities, or bosses of drug cartels. Their power is often derived from different sources that include the power to interpret and enforce 'custom' (non-state) rules and from their ability to tax the population and distribute resources (Earle 1997; Giustozzi 2011a: 25-28). In addition, the authority of local elites often follows from their adherence to traditional values or personal attributes ranging from age to combat experience ('charismatic leadership') (Schmeidl and Karokhail 2009: 329-331 ; Weber 1972: 122-124). Finally, as self-help institutions are usually in some type of relation with both, each other and the central government, local elites can offer their communities access to resources from the state. Taken together, local elites have strong ties with their self-help communities and derive their power mostly (although not exclusively) from these local roots. Thus, the power asymmetry between local elites and their constituency is rather small (Abrutyn and Lawrence 2010: 421-422). This aspect is important but often overlooked by scholars who focus on local elites: Local elite are powerful not simply because they own certain resources, but because they have a position of authority in local institutions. 
Any central government that expands its control into rural areas will face the dilemma of how violence regulation at the local level should occur. There are two options: The government can co-opt the local institutions, or it can attempt to replace them (Gerring et al. 2011: 377-378). Cooptation has several benefits: Coopting existing institutions into the state is cheaper, since they already provide governance at the local level. Additionally, coopting local institutions will buy the state the loyalty of local elites. However, there are also downsides to this approach. Cooptation means that the state cannot properly monitor local communities and, thus, might not be able to notice if local actors mobilize against the state. Furthermore, local elites will control resource extraction and demand a sizable share in form of patronage. This reduces the government's revenues (De Waal 2009: 102-104). Overall, cooptation can be described as a form of indirect rule in which the means of small-scale violence remain in the hand of local non-state actors who deliver stability in exchange for autonomy.

Replacement is the second option, and it is the riskier one for central governments. The benefits are clear: Once a state controls society through police and justice, it can monitor the population and recognize potential threats early on. Furthermore, it can effectively tax the population and hugely increase its revenues (Tilly 1992: 114-116). However, local institutions are deeply entrenched and thus may not be easily removed. Since they often work informally, the local population might simply opt out of the state system and continue to seek informal security. Thus, it can be difficult for state agents to stop these practices. Additionally, the creation of professional police forces and efficient justice are demanding organizational tasks for any state (Giustozzi 2011a: 200-206). What makes replacement even more costly is the fact that there are usually dozens or hundreds local institutions across the country's territory, and the replacement of one will make disloyalty by others much more likely. Put differently, the state would need to destroy an existing social order even if there is violent resistance, and it would have to offer adequate replacement in form of well-organized state bureaucracies. The radicalness of such an approach indicates that central governments will most likely opt for either co-optation or an incremental replacement of local institutions. 


\section{The monopolization process: A brief historical overview}

Across Europe during the $18^{\text {th }}$ and $19^{\text {th }}$ century, self-help communities regulated most of smallscale violence. While the state increasingly became a monopolist of policing in cities throughout the $19^{\text {th }}$ century, the rural areas where most of the population lived were ruled by landed nobility. The army was regularly used when local elites resisted demands of the central government, or when the local population did not obey their local rulers (Reinhard 1999: 363-364). There is a tendency in the literature to focus on the differences between policing systems across Europe, for example by arguing that there is an Anglo-Saxon tradition of democratic policing and a continental tradition of autocratic policing (Reiner 2010: 7). However, more important for this study is the fact that across all countries there has been a development from a decentralized regulation of violence through non-state institutions to an integration and eventually assimilation of these institutions through the state. This process was by no means a foregone conclusion, as local institutions and elites were extremely powerful in early modern Europe. "The magnates collaborated with the government without becoming officials in any strong sense of the term, had some access to government-backed force, and exercised wide discretion within their own territories: junkers, justices of the peace, lords. Yet the same magnates were potential rivals, possible allies of a rebellious people" (Tilly 1985: 174). A brief discussion of the examples of Britain and Prussia will help to illustrate this development.

In pre-industrial England, local elites (Justices of Peace) were the prime regulators of small-scale violence. They would also tax the population and pass revenues on to the central government. While these local institutions where efficient and mostly stable, they could not handle the rare occasions of mass unrests. In these situations, London had to send in the army to restore order (Knöbl 1998: 108-119). When unrest became more frequent due to the effects of industrialization, the government first reacted to this with a strengthening of paramilitary forces instead of the expanding modern policing to the whole of the country (Knöbl 1998: 166-171). Modern policing evolved first in London in 1829 when a 3,300-strong police force was set up in the capital country (Knöbl 1998: 182). Modern state policing expanded slowly but steadily across the UK, starting in the biggest cities. Nevertheless, by the beginning of the $20^{\text {th }}$ century the state controlled a police force of over 50,000 (Knöbl 1998: 291). Overall, the expansion occurred mostly to deal with the threat of riots as well as during times of war or terrorism. Local elites were bereft of their strong autonomy in an incremental process. 
Whereas Britain is usually seen as an example of strong local institutions, Prussia is seen as the typical case of top-down statebuilding. In this narrative, the Prussian government created a centrally-controlled police force that was early on able to suppress resistance and safeguard the monarchs rule. However, a closer look at the power structures of Prussia reveals that the government had much less control than is commonly assumed. The landed nobility, or Junkers, was a major pillar of the state's rule. Local elites had the right to enforce their own custom rules without state interference (Knöbl 1998: 74-78). After the defeat against Napoleon had laid bare the deficiencies of the absolutist order, attempts were made by dedicated reformers to expand police and justice to rural areas and to introduce a centrally-controlled gendarmerie force. These reforms were opposed by conservatives in the government whose power dependent on the support of local elites. Despite the diminishing importance of non-state law, the Junkers even managed to expand their right to punish their subjects, for example through corporal punishment and imprisonment (Knöbl 1998: 206-207). It would take another major crisis half a century later to decidedly weaken the position of the Juncker. Prussia only embarked on the creation of a modern police force in Berlin after the revolution of 1848, and in other cities since the 1870s. At the beginning of World War I, Prussia had a police force strong enough to control all of its territory (Knöbl 1998: 340-343). Thus, in Prussia (i.e. the largest part of Germany) the eventual collapse of the local institutions that had regulated everyday violence for centuries paved the way for the eventual breakthrough of a state-centered order in the early $20^{\text {th }}$ century.

In large parts of the contemporary world society, states have not monopolized the regulation of small-scale violence. Some of these para states are obvious, as the state is either too weak to be present outside its capital, or it has created institutions that co-opt self-help communities. In sub-Sahara Africa, the chieftaincy has developed from a colonial institution (built on older power structures) into a pillar of many weak states (De Waal 2009; Trotha 1996). In the Arab world and other parts of the Middle East, nationalist statebuilding has often created the impression of bureaucratic statehood, while tribes remained in a strong position at the local level (Khoury and Kostiner 1990). Even emerging markets such as Latin American countries have not fully monopolized the regulation of small-scale violence (Bailey and Taylor 2009). The fact that the Brazilian government had to deploy its armed forces to take control of favelas hitherto controlled by organized crime attests to these struggles. Overall, a lot has been written about state failure in places where violence is regulated by non-state institutions. However, the 
more appropriate view would be to view states that regulate small-scale violence as the exception. In most state-like entities most of the time, there were some forms of local elites which had to be integrated into the polity (North et al. 2009). With this historical overview in mind, the next section will probe the existing state formation literature for theories that could explain the emergence of state monopolies on small-scale violence regulation.

\section{State formation theories and the regulation of small-scale violence}

Scholars of state formation have been much more concerned with large-scale violence than with the regulation of small-scale violence. Thus, it is difficult to distill specific hypotheses from the literature. However, two important aspects are worth mentioning. First, the state had to develop organizations that were more effective and legitimate than the existing order. And, second, the population had to internalize this state order.

One important school of thought has argued that the replacement of local elites through state police, justice, and administration is part of a bargaining process. The ratcheting up of state revenue extraction has been briefly delineated in the discussion of the state formation literature above. As the state increased revenues from taxation and drafted its male population for service in the armed forces, the population increasingly demanded something in return. Tilly argues that rulers conceded an increasing number of rights to their subjects, thereby turning them into citizens. Furthermore, the state had to deliver public services including the provision of security and justice. This process of statemaking disempowered local elites over time. Thus, it became easier for central governments to either buy-off or eliminate local elites and, thereby, local institutions (Tilly 1985: 173-175). Overall, state formation scholars see the 'statemaking' as driven by the same process as the monopolization of large-scale violence: The state needed resources to wage war, and resource extraction could be improved by establishing direct policing of the population.

A second strand of scholarship places a greater emphasis on the social embeddedness of the state. Instead of seeing the replacement of non-state institutions as a product of bargaining between central governments and the population, some scholars have argued that it took the socialization of individuals into a state order. By expanding state bureaucracies to the local level 
in both urban and rural settings, the state had not yet disempowered local elites. However, these state institutions changed the citizens' expectations over time. Mandatory schooling and conscription made it possible to subject all of the population to state institutions (Schlichte 2005a: 100-101). Here, people were disciplined and instilled with new beliefs about what constitutes legitimate political rule. Elias (Elias 1939[2000]) has termed this 'taming' of the population as the civilizing process. Over time, subjects of state rule developed into citizens who saw the rule by government as the only legitimate form of political order: State order became the natural order (Foucault 1991; Mann 1993: 730-731). Thus, not only did state institutions make non-state institutions redundant, they also delegitimized them in the long run. To sum up this line of argument, the growth of state institutions has over time turned subjects into citizens that accept state rule as the only legitimate form political order.

There is an important sequence in the development of the modern European state. The monopolization of large-scale violence was largely detached from the question of legitimization through the population. Until the French Revolution, European rulers saw no need to justify their rule and, in particular, the fact that they had monopolized large-scale violence. After 1800, the expansion of the state into the regulation of small-scale violence and the replacement of local elites went hand in hand with the expansion of citizen rights. The $19^{\text {th }}$ century saw both a massive expansion of state power and a process that Elias called the Vergesellschaftung des Gewaltmonopol (Elias 1997: 230-231). Control over the means of violence went from being a personal attribute (of the king) to being a public office. Hence, whereas the appropriation of the means of large-scale violence by the central government seems to have had little need for legitimization practices, the establishment of local state policing turned subjects into citizens. As the state imposed a tough regime of monitoring, taxation, and sanctioning, people increasingly demanded to be protected against misuse of state power (Tilly 1992). Taken together, the regulation of large-scale violence seems to be normatively less demanding than the regulation of small-scale violence.

As this discussion shows, the institutionalization of a purely state-centered order of violence in Europe took centuries. During this time period, the existing non-state institutions were gradually incorporated and substituted by the state. Local elites who benefitted from these institutions lost their autonomy in the face of increased bureaucratization, and their authority waned as the state offered better services to its citizens. Individuals were socialized into a state- 
centered order where the private use of force became a taboo. The result was a new institutional arrangement to which both elites and the broader population were committed.

\section{Conclusion: Direct or Indirect Rule}

As this discussion tried to make clear, small-scale violence regulation is ubiquitous in human societies. While in practice, many institutional forms of regulation exist, they can broadly be categorized into self-help communities and state orders. Self-help communities can exist with or without a state. Monopolizing the regulation of small-scale violence offers huge rewards for statebuilders, but the process itself is highly risky. The modern, developed state has managed to monopolize the regulation of small-scale violence. This was again achieved through a combination of organizational and institutional innovation. Whereas bureaucratized police forces are the organization that provides states with a tool of small-scale violence regulation, this only works in an institutional environment that includes local administration, courts, and the absence of competing institutional arrangements.

The key insight of this approach towards small-scale violence regulation is that a government that aims at monopolization will have to confront existing institutions. Thus, the chance of success depends on the relative strength of the self-help communities and the local elites that would need to be replaced. A stronger central government will have greater bargaining power vis-à-vis local actors. However, given the high durability of these kinds of institutions, we should not expect governments to monopolize small-scale violence in short time periods even if other conditions are highly favorable. Instead, the monopolization process will occur incrementally, and for long periods, non-state and state institutions will exist in parallel. Worse for statebuilders, efforts to monopolize can lead to counter-reactions and setbacks. In sum, the monopolization of small-scale violence regulation is a slow, protracted, and non-linear process. As a consequence, governments will often refrain from taking the risk of monopolization and opt for managing the status quo (Staniland 2012). Nevertheless, central governments will need to find ways to incorporate local elites if they want to succeed in the long run. 


\subsection{Conclusion}

This chapter has developed a neo-institutionalist outlook on the relationship between violence and politics. Violence needs to be regulated in human societies, it is a major source of power, and different forms of regulation have developed in history. As I have argued, drawing a distinction between large-scale violence and small-scale violence is analytically fruitful because these forms of violence require different forms of regulation. The modern state has monopolized the regulation of both types of violence, and thereby achieved a great decline in actual violence.

One question needs to be settled before advancing to the analysis of statebuilding interventions: What is the relation between large-scale violence and small-scale violence? Do institutions that regulate large-scale violence and small-scale violence affect each other? The answer to this is that it depends on the type of state formation we are dealing with. Historically, both types of violence regulation were often very much intertwined. The historical development of the state monopoly on violence followed a clear sequence. Around 1800, European states had completed the monopolization of large-scale violence and began to monopolize small-scale violence regulation (Tilly 1992: 103-107). As a result, by the beginning of the First World War, Western European states had full monopolies on violence regulation. The sequence of monopolization had three main reasons. First, state formation did not occur according to any long-term plan (Tilly 1992: 25-27). For example, the fact that military conscription tied the population closer to the state was a byproduct of the simple need to mobilize large numbers of troops to survive as a sovereign entity in European politics. Second, it took a powerful central government to take on the nobility (Tilly 1985: 173-175). Governments could not afford challenging local institutions in a context where local elites could ally up to fight the state or seek the support of other armed actors. Third, all of the necessary institutional and organizational innovations from standing armies to modern policing and bureaucratic administrations were very expensive (Tilly 1992: 87-91). Governments had either to increase taxation or to borrow from domestic capitalists (and increase taxation later) in order to pay for all statebuilding measures. Taken together, the undirected development, the relative weakness of central governments, and the necessary increases in resource extraction made the establishment of both monopolies a protracted process spanning several centuries. In sum, large-scale violence monopolization was the prerequisite for a monopoly on small-scale violence. 
The context in contemporary world society has greatly changed. A full monopoly on violence is no longer a random outcome of an undirected process, but a goal that can be intentionally pursued. Capital and weapons have become more readily available through global markets on which emerging states can sell commodities. Additionally, a host of international organizations interfere in the internal affairs of weak states (Migdal and Schlichte 2005: 32-34). The capacities of states vary widely, both when it comes to large-scale and small-scale violence (BTI 2014a). In many parts of Africa and the Middle East, states lack a monopoly on large-scale violence. Most of these states clearly also lack a monopoly on small-scale violence regulation and can thus be considered as weak or para states. In contrast, there are cases of secessionist wars in the Balkans or Ukraine where small-scale violence had been monopolized by the state. State police forces often times kept operating and enforcing state law even though their city had been conquered by an armed group. As a result, small-scale violence can be regulated in a bureaucratized, state-centered way while the state itself is separated into different 'zones of control' (i.e. has no monopoly on large-scale violence). However, these are cases of fragmentation of existing states. Overall, although the world historical context has greatly changed, the basic sequence remains largely intact. Similar to early modern Europe, current states need to monopolize large-scale violence first, and these state formation processes lead to both intra-state and inter-state wars. As the next chapter shows, statebuilding interventions diverge from this pattern as they display a stronger disconnect between large-scale violence and smallscale violence regulation. 


\section{Liberal Statebuilding Interventions and the Regulation of Violence}

Why do liberal statebuilding interventions sometimes succeed but often fail to establish a state monopoly on violence? By combining the insights from the state formation literature with the findings from the three case studies ${ }^{15}$ this chapter provides an answer to the main research question of the dissertation. Based on the distinction of large-scale and small-scale violence developed in chapter two, I argue that statebuilding interventions will result in the creation of a state with a full monopoly on violence when two conditions are in place: First, the statebuilding intervention is supported by key regional actors, and, second, the target society had a history of strong statehood prior to the crisis that triggered intervention. If one of these conditions is missing, the second-best outcome is a partial monopoly on violence (i.e. on either large-scale or small-scale violence).

The first argument is that statebuilding interventions lead to the establishment of a state monopoly on large-scale violence when the intervening actors and key regional actors have a common interest in statebuilding. Where intervening and regional actors cooperate, the borders of the target state can be secured either because neighbor states directly support the intervention, or because a regional alliance can force neighboring states into compliance. Making borders effective will forestall a transnationalization of the conflict, thereby depriving armed groups of access to markets and zones of retreat. Since the intervention strongly improves the coercive capabilities of the central government, it will be able to monopolize the means of large-scale violence once territorial integrity is (re)established. However, when major regional powers oppose the intervention, a monopolization of large-scale violence becomes highly unlikely. In such a constellation, the opponents of statebuilding will resort to transnationalization strategies. Where key regional states grant armed groups access to transnational spaces, the statebuilding intervention will fail as the armed groups manage to survive the externally induced expansion of state power.

The case studies in the following chapters provide ample evidence for these causal mechanisms. In Afghanistan, the armed group that resists the government's monopolization efforts enjoys the direct and indirect support of a neighboring country. The analysis of the

\footnotetext{
${ }^{15}$ See chapters $4-6$.
} 
Taliban insurgency shows that the group could resist disarmament because it could use Pakistani territory as a sanctuary that offered access to global markets and protection for the organization's leadership. In Sierra Leone and Bosnia-Herzegovina, the regional constellation was much more favorable for the intervening actors. The Sierra Leonean armed group Revolutionary United Front (RUF) was highly dependent on access to Liberian territory. When a regional alliance supported the UN in its statebuilding effort and succeeded in cutting off the RUF from its Liberian sanctuaries, the intervention built a stable monopoly on large-scale violence. Bosnia-Herzegovina is a useful case at it displays variance in regional politics. In the first five years of intervention, Bosnia's neighboring states Croatia and Serbia were hostile to the statebuilding effort. Due to radical reforms around the year 2000, their support for the Bosnian-Croat and Bosnian-Serb groups dried up and they accepted Bosnia's sovereignty. By 2005, the statebuilding intervention succeeded in monopolizing the means of large-scale violence.

The second argument is that statebuilding interventions will establish a state monopoly on the regulation of small-scale violence if the country had a history of strong statehood prior to the crisis that triggered intervention. Where the state had completed the monopolization of smallscale violence regulation prior to the crisis, people will continue to expect the state to fulfill this function, and they lack alternative institutions that could offer them everyday security. If there was a weak state beforehand, self-help communities will be well institutionalized across the country. Statebuilders train police forces but cannot change the institutional structure at the local level, where local elites resist monopolization by the center. Thus, statebuilding interventions in countries that never had a strong state will lead to 'para statehood' in which state and non-state institutions of small-scale violence regulation co-exist.

The case of Bosnia-Herzegovina highlights the importance of a history of strong statehood. Although it has not been a sovereign state for centuries, Bosnia has been exposed to statebuilding efforts by Ottoman Empire, Austria-Hungary and Yugoslavia. Since the mid-19 century, the self-help communities were slowly replaced by a state that policed, educated and indoctrinated its society. Thus, the intervention occurred in a society that had been exposed to a strong state and readily accepted the re-establishment of a state monopoly on small-scale violence after the war. Afghanistan and Sierra Leone provide stark contrasts. In these cases, the state has never been strong enough to replace self-help communities, and these institutions proved resilient enough to outlast the civil wars that devastated both countries. At the outset of intervention, 
governments had to rely on local elites so as to create a basic order after war. Therefore, when the statebuilding interventions embarked on the creation of formal institutions and bureaucratic policing, local elites were in a position to either block the monopolization efforts or capture them. As a result, in both cases the outcome was a para state in which self-help communities and formal policing exist in parallel.

The following sections develop the argument in detail. In each of the two sections, I provide the reader with a brief overview of common monopolization strategies in statebuilding interventions. Afterwards, I discuss what we can learn from the literature about the effectiveness of these statebuilding approaches. Finally, I combine my theoretical assumptions, the knowledge derived from the literature, and insights from the case studies to construct the causal mechanisms that can explain the outcomes of statebuilding interventions.

\subsection{Statebuilding Intervention and Large-Scale Violence}

This section develops an explanation for the effects of statebuilding interventions on the regulation of large-scale violence. The argument put forward is that regional politics are the main condition that determines whether statebuilding will succeed or failure to regulate large-scale violence. I develop two causal mechanisms by first summarizing the major strategies of largescale violence monopolization in statebuilding: Disarmament, Demobilization, and Reintegration (DDR), and parts of Security Sector Reform (SSR) such as the creation of a professional army. The literature review finds that external statebuilding is generally effective in supporting the establishment of new formal institutions and in providing the government of the new polity with the organizational capacity to wield large-scale violence. However, whether this support also leads to a monopoly on large-scale violence depends on those actors who oppose monopolization. If they are able to organize sustained armed resistance, the intervention will most likely be

aborted. New research on civil war suggests that the ability of armed groups to resist depends on their access to transnational spaces. Therefore, whether regional actors allow or deny armed groups this kind of support is crucial for the success or failure of large-scale violence 
monopolization in statebuilding interventions. I begin with an overview of intervening actors' strategies of monopolization.

\section{Monopolization Strategies}

In order to establish a state monopoly on large-scale violence, intervening actors have spent large amounts of time and resources in post-conflict societies. The challenge for statebuilders is to provide the government with means of warfare while taking these means from all non-state actors. Interveners have developed two major strategies to foster the monopolization of violence in statebuilding missions: DDR and SSR (McFate 2011:214).

Disarmament, Demobilization, and Reintegration is aimed at armed non-state actors and mostly concerned with organizational capacities. As the name suggests, the DDR strategy is meant to defuse the threat from armed groups by orderly dissolving them. Without armed competitors, the state only needs to rebuild armed forces to obtain a monopoly on large-scale violence. DDR operations first disarm non-state actors: "Disarmament is the collection, documentation, control and disposal of small arms, ammunition, explosives and light and heavy weapons of combatants and often also of the civilian population" (UN 2014: 1). Afterwards, measures are taken to separate these (ex-) fighters from their combatant networks and offer them opportunities to find a civilian occupation. However, when armed groups resist disarmament, DDR cannot be conducted. Instead, interveners increasingly use force to coerce armed groups into compliance. This is illustrated by the spread of counterinsurgency (COIN) strategies from NATO missions in Afghanistan and Iraq (U.S.Army 2007) to current UN missions such as the one in the D.R. Congo (UNSC 2013).

Compared to DDR, Security Sector Reform is a much more encompassing concept. Whereas armed actors have to be disarmed in all violence monopolization processes, SSR gives them a distinctive liberal character. In a nutshell, SSR aims at providing governments with means of violence that are embedded in a liberal institutional framework. With regard to large-scale violence, SSR aims at the creation of armed forces that are supposed to be effective, politically controllable, and economically sustainable. The use of force should be regulated according to the

principles of democratic accountability and rational-legal authority, and be constrained by the 
rule of law (UN 2008a: 6-7) (Schröder and Kode 2012: 33). Institutionally, this means establishing Ministries of Defense that can actually control the army.

Their support comes in the form of training and professionalization, funding, and by providing a security umbrella as long as the state's armed forces are not strong enough to secure a monopoly on large-scale violence. Training and professionalization are mean to make the army both effective and politically controllable. At the level of rank and file soldiers, external actors assist recruitment and basic combat training. Professionalization occurs at all levels as the army leadership is reduced to a small core of capable officers (Dobbins 2007: 34-35). A central goal of army-building is thus to build a de-politicized officers corps that works according to an ethos of subordination to political elites. SSR tries to overcome this politicization by professionalizing armed forces, mainly by shifting the focus of recruitment and promotion from loyalty to meritocracy (Giustozzi 2011a: 45). The funding of the army is arguably the most crucial help for governments of that struggle to regain control over their territory. Support can range from the provision of basic equipment to paying for the personnel costs of the new army (Dobbins 2007: 35-36). The inflow of resources enables governments to fund substantial armies without first engaging in the laborious process of building taxation capacities. However, this also makes SSR one of the most expensive components of statebuilding. In Afghanistan alone NATO spends 3.5 billion dollars per year to fund the Afghan National Army (TheAtlantic 2012).

If SSR would work according to plan, a monopoly on violence and democracy would be created at the same time. Control over the armed forces would thus be regulated through elections and the constitution would limit the power of governments to abuse its means of violence. The state would not only be strong but also legitimate. Critics have argued that democracy is seen as legitimate by external actors and the $\mathrm{UN}$ in general, but might not be the type of institution that is seen as legitimate by the people of the intervention society (Lake 2010b: 35-36). Nevertheless, democratic access to the monopoly on large-scale violence appears to be a widely accepted procedure to give authority to the state. Surveys in developing countries frequently show great support for democracy, although sometimes the meaning of democracy might differ somewhat from that in the US or Europe (Bratton 2007). One crucial problem with democracy, however, is the fact that it only works in states that have a monopoly on large-scale violence (Møller and Skaaning 2011). In combination, the regulation of large-scale violence and the establishment of an electoral democracy provide a sound source of authority for the newly established polity. 
Where competitors are armed or parts of the country are under rebel control, elections can result in renewed conflict. Thus, "[..] current state-builders are putting the proverbial cart before the horse by emphasizing democratization over security [..]" (Lake 2010b: 47-48). This does not imply that it does not matter whether external actors build democratic or authoritarian institutions, but it implies that the democratic institutions will only become effective once the monopoly on violence is established.

Taken together, liberal statebuilding interventions make extremely costly efforts to create state monopolies on large-scale violence. Their focus is on providing the central government with the organizational capacity to establish and sustain a monopoly on large-scale violence. In order to constrain the ability of the government to abuse these new coercive capabilities, statebuilders create formal democratic institutions. With this in mind, the next section will discuss the scientific literature on interventions and draw some broad conclusions about the effects of liberal statebuilding on its target societies.

\section{State of the Art: Interventions and large-scale violence}

When do statebuilding interventions succeed in monopolizing the means violence? In this brief literature review, I look at existing research with the aim to distil important factors that might help to explain the outcomes in terms of violence regulation. The literature review reveals that there has been a great debate between 'problem-solving' and 'critical' scholars who have focused on either external or domestic factors. In recent years, new scholarship on civil war and democratization has pointed out the importance of regional factors for domestic politics.

Research on the question of how large-scale violence regulation is affected by interventions can be broadly categorized according to its level of analysis: International, domestic/local, and regional. Much of the initial scholarship on statebuilding dealt with the international level and focused on strategies to improve the outcomes of international interventions. These authors argued that statebuilding can be successful if interveners apply the right strategies and the appropriate amount of resources (Lake 2010a: 259 ; Paris and Sisk 2009: 13-14), thereby implying that these are the key variables to explain the outcomes. One influential argument was that the monopolization of the means of large-scale violence requires a large 
foreign troop presence. In this perspective, by first monopolizing violence in the hands of the foreign military and then handing it over to the new government, a 'security vacuum' could be avoided (Chesterman 2004: 99-101). Dobbins (2007: 41) argues that troop size for interventions requires "[..] an average of 13 soldiers per 1,000 inhabitants for peace enforcement operations, and two soldiers per 1,000 inhabitants for peacekeeping operations". Others have put more emphasis on well-planned DDR or SSR campaigns. First, former combatants should be systematically disarmed and reintegrated into society. Second, the security sector should be built according to principles of democratic accountability and subjected to the rule of law. The assumption is that if the according formal institutional framework is created and when professional armed forces are being trained, then the monopolization of violence will succeed (Hänggi 2004; Rubin 2008: 28-31 ; Sedra 2013).

The strategies and resources of external actors certainly play an important role in statebuilding interventions. For example, recent research indicates that large troop deployments increase the chances of successful peacebuilding (Hultman et al. 2014; Ruggeri et al. 2013). Under the conditions of ongoing or simmering conflicts, a strong troop presence and DDR as well as SSR policies might be necessary for success in terms of monopolization of violence, but they are not sufficient. Leading actors of statebuilding, among them the UN, the US, and the EU have all adopted intervention policies that revolve around the above cited 'lessons learned'. There have been several statebuilding missions with more than 10,000 troops deployed (Afghanistan, Bosnia, DR Congo, East Timor, Iraq, Kosovo, Liberia, Sierra Leone). Among them, there have been successful cases (in terms of monopoly on large-scale violence) with less than 3 soldiers per 1,000 inhabitants (Liberia, Sierra Leone), as well as failures with comparatively high levels of 5 or more soldiers per 1,000 inhabitants (Afghanistan, Iraq). In almost all cases, the international actors have conducted DDR and SSR strategies. Thus, purely focusing on the external actors and the variables they can control does not suffice to explain the wide differences in outcomes.

Accordingly, the 'problem-solving' approach received stark criticism for ignoring the politics and social structures of those societies where intervention took place (e.g. Chandler 2007; Mac Ginty 2010a; Richmond 2005). Across the field, the level of analysis has moved to the national and then local level. For example, SSR, the main tool for regulating large-scale violence, is often seen as a technical fix for security-related problems. Critics have argued that, far from of being an apolitical technical solution that can be applied in any given context, SSR touches upon 
highly political issues: "[at] the heart of SSR are the core values of democracy, good governance, gender equality, transparency and accountability, as well as a desire to propagate universal human rights" (Jackson 2011: 1810). Thus, what sounds like a reasonable policy for a seemingly limited aspect of statehood and peace in fact easily amounts to far-reaching social engineering. Such dramatic societal changes are likely to create opposition by those who lose out, resulting in (armed) opposition to statebuilding (Mac Ginty 2012; Richmond 2010: 21-25). On the side of those who benefit from statebuilding, the investment of interveners into a monopoly on largescale violence might create incentives that undermine the monopolization effort in the long run. According to Giustozzi (2011a: 175-177), statebuilding has a 'crowding out' effect. Since foreign troops can bear the brunt of security provision, there is little incentive for central governments to genuinely invest into armed forces. Thus, the army built by externals remains a weak, artificial organization. Overall, the biggest contribution of critical scholars was to show that statebuilding is not just a technical exercise of constructing institutions, but a highly political endeavor that will trigger resistance.

However, as I have argued in the introduction, the focus on the national-internationalnexus fails to account the variation in outcomes. Interventions always create winners and losers, so why do some of them organize violent resistance while others accept the newly created polity? Recent progress in the study of civil wars and intervention offers a clue, as the focus of attention has shifted to transnational and regional factors that affect statebuilding. Until recently, statebuilding and peacebuilding research has suffered from what Haldén (Haldén 2010) has called 'endogeneity bias'. In this account, the problem of statebuilding is one of regional state formation. The emergence of a regional state system has to precede the creation of the single state. Thus, whereas statebuilding is solely focused on building domestic institutions, these efforts cannot succeed as long as there is no strong regional norm of statehood (Haldén 2010, 2013). This systemic view is supported by empirical works on civil wars that show that conflicts in which armed actors have access to transnational spaces last longer, and that conflict clusters in regions (Gleditsch 2007; Pugh et al. 2003). Furthermore, this clustering effect can also be seen in the study of democratization, where the direct neighborhood of a state affects its regime type (Zuercher et al. 2013).

To sum up, the literature has offered important insights for a theory that seeks to explain the variation in outcomes of external monopolization. Mobilizing larger amounts of resources and 
staging well-planned DDR and SSR are conducive to statebuilding, but they are not sufficient on their own. Any statebuilding intervention will always create political winners and losers. Therefore, resistance by certain political actors is likely. Whether this resistance is violent will greatly depend on oppositional groups' access to transnational supply networks.

\section{The Regulation of Large-Scale Violence in Statebuilding Interventions}

This section combines the insights from the literature on state formation and statebuilding interventions with the findings of my case studies. My argument is that statebuilding interventions can succeed in monopolizing the means of large-scale violence in the hand of the government. However, statebuilding interventions will only establish a state monopoly on warfare if it is supported by key actors in the region. This constellation will trigger what I call the regional cooperation mechanism. In contrast, where important neighboring states oppose the statebuilding intervention, the monopolization of large-scale violence is almost impossible to achieve in the short time span of a statebuilding mission. Such a set up will trigger a regional competition mechanism in which outside actors opposing statebuilding actively undermine monopolization efforts. In the following paragraphs, I will briefly summarize the broader theoretical insights with which I approached the empirical material.

At the beginning of statebuilding interventions, the means of large-scale violence are dispersed among two or more actors. The state is not strong enough to disarm armed groups either through bargaining or through force. External military forces instantly shift the balance of power in favor of the central government. Statebuilding interventions support governments in building specific (liberal) formal institutions and in developing organizational capacities of largescale violence (armed forces). Thereby, the intervention further strengthens the central government vis-à-vis armed competitors. At the same time as the state increases its capacity to control large-scale violence, the statebuilders press for DDR. Whether armed groups give in to these demands or resist disarmament will depend on their capacity to successfully resist the statebuilding effort until external actors depart from the country. As the research on civil wars has shown, armed groups can greatly enhance their organizational capacities if they have access to transnational markets and cross-border sanctuaries. 
In the case of statebuilding interventions, regional actors must decide whether their interests are best served by supporting the statebuilding effort or by supporting the armed groups. There are two important differences between regional actors and interveners: First, regional actors have strong interests in their neighboring states because it directly affects their security, while intervening actors have usually less stark motivations and their intervention is rather optional ('war of choice'). Second, the regional actors have very long time horizons as they have to live with the outcomes of intervention. They can thus apply long-term strategies, while interveners will eventually withdraw from the region after a limited period of time. This asymmetry makes sabotaging statebuilding easier for regional actors even if they are not as materially powerful as the intervening actors.

From this follows that statebuilding interventions will be limited by the social structures that exist in any given region. The last chapter has argued that statehood is a regional institution that requires that political elites in the region mutually accept the territorial integrity of neighboring states. States are built from the inside as well as from the outside. Interveners strengthen the organizational capacity of the government, but they cannot change the fundamentals of a region. The relations of political actors in these regions can be characterized by cooperation as well as conflict. Since statebuilding interventions will change the status quo, regional actors such as great powers and neighboring states are affected by the outcomes. Depending on how they assess the changes, they will either support statebuilding or fight it.

The case studies show that regional support for statebuilding led to an isolation of nonstate armed groups. External support shifted the balance of power to the central government, and without transnational supply networks, the armed actors had to yield to monopolization. The actual monopolization process took very different forms in the cases of Bosnia-Herzegovina and Sierra Leone. Whereas Bosnia experienced a peaceful bargaining process between armed actors, monopolization in Sierra Leone was conducted forcefully until the RUF accepted disarmament. Nonetheless, in both cases the monopolization enabled the statebuilding mission to consolidate the monopoly through institutional reform and capacity building. In contrast, statebuilding in Afghanistan was actively undermined by Pakistan. Pakistan's support allowed the Taliban to transnationalize their activities and evade defeat in Afghanistan. Their ability to survive major monopolization efforts enabled them to prolong the conflict. Eventually, the international actors withdrew without establishing a monopoly on large-scale violence. Figure 4 and figure 5 show 
abstractions of the causal chains that could be observed in the case studies. The next paragraphs will present the mechanism in detail.

\section{The Regional Cooperation Mechanism}

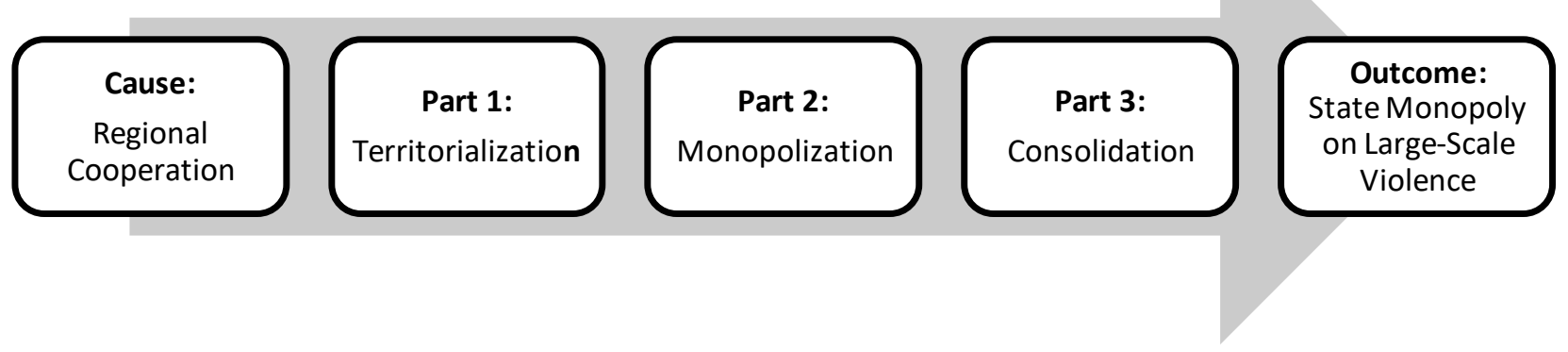

Figure 4: Regional cooperation mechanism.

The mechanism is triggered by key regional actors supporting the statebuilding intervention. Key regional actors are political elites both in neighboring countries and in the major regional powers. While additional support for the intervention is helpful, the minimum of support is that these elites have to accept the territorial integrity of the state where intervention takes place. Such a consensus allows for the institutionalization of statehood in the region. In such a situation, the government of the intervention state only needs to acquire the organizational means of large-scale violence.

(1) Territorialization: Regional cooperation allows for an enforcement of the border regime. The conflict is transformed from a transnational into a national one. Establishing territoriality is crucial, as control over borders cuts off armed groups from access to safe havens in neighboring states and prevents them from supplying themselves on global markets. Where individual actors (armed groups, governments of small states) support opponents of the monopolization efforts, they can be pressured into compliance by concerted efforts of intervening actors and regional governments. 
(2) Monopolization: The second step of the mechanism concerns the dismantling of armed groups. Once they lack access to transnational spaces, they are unlikely to withstand the material superiority of international statebuilding missions. The combination of lack of supplies, military pressure through foreign troops and, increasingly, growing domestic armed forces eventually leads to a collapse of the organizational capacity for large-scale violence: The armed group is being disarmed.

(3) Consolidation: The third step concerns the organizational capacity of the government. As the means of large-scale violence have been monopolized with the disarmament of nonstate actors, the monopoly needs to be institutionalized. Without the military pressure of an ongoing insurgency, the armed forces can be professionalized, put under political control, and reduced in size that is economically sustainable.

A full state monopoly on large-scale violence is achieved when there are no more armed groups on the state's territory, the central government controls capable armed forces, and the intervening actors have withdrawn their troops from the country.

\section{The Regional Competition Mechanism}

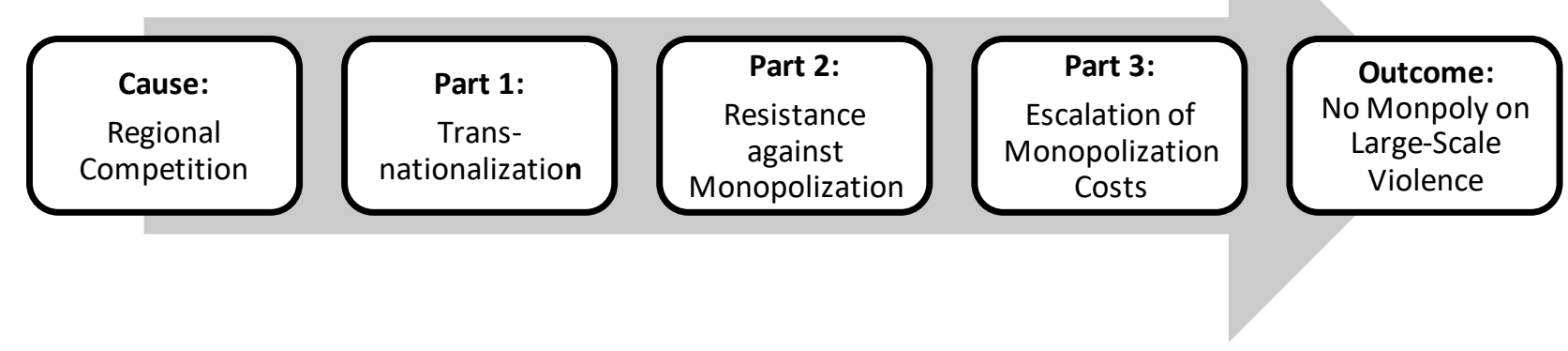

Figure 5: Regional competition mechanism.

In contrast, the regional competition mechanism is triggered when key regional actors oppose the goals of the statebuilding intervention. In these cases, the regional actor will support the armed groups that oppose the new government. The power of regional actors derives less from their 
material capabilities than from the fact that they can undermine the territorial integrity of the state to be built. Such policies lead to the following causal mechanism:

(1) Transnationalization: The first step of the mechanism is the transnationalization of conflict. Neighboring states that do not accept the state's territorial integrity allow armed groups to freely cross borders. Access to this transnational space offers armed groups sanctuaries as well as access to global markets.

(2) Resistance against Monopolization: Step two of the mechanism is the organizational consequence of the lack of territoriality. The interveners foster the monopolization process by supporting the creation of security forces and by expanding the government's area of control. At the same time, sanctuary and access to markets greatly enhance the organizational capacities of armed groups and shield them from disarmament through the central government.

(3) Escalation of Costs: In reaction to the growing strength of armed groups, external actors will invest more into the armed forces of the government. Armed groups keep evading their elimination by accessing transnational space. Eventually, the costs of statebuilding escalate and eventually lead to a withdrawal of international actors.

There are two possible outcomes, neither of which is a monopoly on violence. The failure to monopolize can lead to (continued) civil war, thus creating something akin to a market of violence. Alternatively, government and armed groups might consolidate their control over territories and form something closer to an oligopoly of violence.

\section{Conclusion}

To sum up the insights of this section, the establishment of a monopoly on the means of warfare is a major goal of statebuilding interventions. In order to achieve this goal, external actors can greatly enhance the organizational capacities of governments through funding, training, and equipping modern armed forces. However, as the section made clear, these efforts are on their own not sufficient for successful monopolization. If powerful regional actors oppose the statebuilding intervention, their support for armed groups can undermine the efforts. Armed 
groups with access to trans national spaces are likely to outlast the intervention and challenge the central government in the long term.

If the regional institutional setting is crucial to monopolization efforts, can intervening actors change the regional constellation? The answer is a qualified no. Regional political constellations are often times highly complex and have grown over long time periods. If neighboring states see it as vital for their national security to transgress national boundaries, changing their preferences is likely to be beyond the capabilities of external actors such as the UN and the US. Nevertheless, there are circumstances in which interveners still have great leverage over regional politics. As the case study of Bosnia-Herzegovina will show, the fact that the Balkans are located directly in the sphere of influence of the European Union eventually contributed to a change of preferences in Bosnia's neighboring countries Croatia and Serbia. However, across the globe the regional spaces in which intervening actors enjoy such superiority are becoming rarer.

\subsection{Statebuilding Intervention and Small-Scale Violence}

When do statebuilding interventions create a state monopoly on small-scale violence regulation? This section provides causal mechanisms that can explain the observed variation in outcomes. The central argument is that the long-term state formation creates legacies that affect the ability of statebuilders to monopolize small-scale violence regulation. Societies that have been governed by a strong state prior to the conflict lack self-help communities that could effectively regulate small-scale violence. Thus, in these societies the expansion of formal policing can lead to a successful monopolization of small-scale violence regulation. In contrast, societies that have never developed a strong state prior to the intervention have developed strong self-help communities. The existence of these local institutions and powerful local elites blocks efforts of international actors to foster the monopolization of small-scale violence regulation. The result is a form of para statehood in which state police and self-help communities co-exist in large parts of the country.

The section develops the argument in three steps. In a first step, I present the most common strategies applied by interveners to achieve their goal of creating a bureaucratic state 
order across the territory. Again, SSR is the most important tool as it includes the creation of an institutional framework (law, local government, courts, ministries, etc.) as well as the capacity to enforce rules by building a modern police force. In a second step, I review the literature on smallscale violence regulation through intervention. Whereas researchers initially thought about postconflict societies in terms of anarchy and 'power vacuums', there has been a 'local turn' in recent years. There is now a consensus that weak states often have very strong non-state institutions at the local level, but there is no agreement on what this means for statebuilding. While some authors see local elites as spoilers of peace that need to be weakened, others have argued for an inclusion of these actors. Despite this local turn, research on policing in statebuilding interventions remains scarce and focuses largely on technical aspects of training and organization. By bringing together research on local institutions and police-building, I argue that statebuilders neither create powerful enough governments nor last long enough to successfully challenge self-help communities. Before presenting my causal mechanisms in detail, I will briefly present common strategies of small-scale violence monopolization in statebuilding interventions and review the corresponding literature.

\section{Monopolization Strategies}

Statebuilding interventions aim at the monopolization of small-scale violence regulation in the hands of the government as part of a wider effort to create a liberal, state-centered security architecture. International actors make use of Security Sector Reform to achieve these goals: "Two related central themes have emerged. The first is that security, human rights and development are interdependent and mutually reinforcing conditions for sustainable peace. The second is the recognition that these fundamental elements can be achieved only within a broad framework of the rule of law" (UN 2008a: 3). However, a necessary condition for liberalization is that small-scale violence is regulated through bureaucratized state institutions. Therefore, intervening actors support the government in establishing formal state institutions (i.e. constitution, administration, courts, etc.) as well as the organizational means of small-scale violence regulation (i.e. police).

The expansion of government control across the territory and down to the district level is pursued through the establishment of formal state institutions. On the macro-level, the 
constitution provides the legal framework in which law enforcement agencies operate (Schröder and Kode 2012: 33). Regarding the justice system, support by external actors usually includes the training of judges in rule of law missions and other material support (McFate 2011: 220). However, all of these formal institutions need an enforcement mechanism to be effective (Trotha 1995: 133-134). Thus, police-building is the core feature of externally-led efforts to create a state monopoly on small-scale violence regulation.

International police-building tries to build bureaucratically organized police forces. Thus, police-building in statebuilding missions resembles in many ways the efforts to build armed forces. External actors provide funds and police trainers to the government, and in return they formulate reforms regarding organizational structures or recruitment procedures (OECD 2007a). In cases where police units have been involved in grave human rights violations prior to intervention, external actors often conduct 'screenings' in order to dismiss officers who were involved in atrocities (Bliesemann de Guevara 2009: 190-191). Part of SSR is also an assessment of how many police forces are needed, so that personnel strength targets are formulated. Furthermore, a focus on local accountability and professionalization aims at making officers less susceptible to corruption (OECD 2007a). Statebuilding missions regularly put a special emphasis on the need to make the police (democratically) accountable, less repressive, and to respect human rights. One concept that is often invoked is that of community policing. Based on AngloSaxon models of police, the idea is to reduce the potential of government's using police for repression by making the police force accountable to local communities (Giustozzi 2011a: 182$183)$.

Overall, the standard statebuilding approach treats small-scale violence regulation as a mostly organizational problem. The assumption is that the state needs to be endowed with a professional, properly sized police force. Corruption and repression are seen as the main problems. Once this force is in place, the state can exercise control over the population. Political considerations deal mostly with questions of local accountability and democratic oversight, but do not go beyond liberal prescriptions for policing. 


\section{State of the Art: Interventions and small-scale violence}

With regard to the regulation of small-scale violence, two important strands of literature can be identified. First, some of the literature on SSR has dealt with police-building by focusing mostly on organizational aspects. Second, there is a growing body of literature on local non-state institutions and actors that regulate small-scale violence. Scholars who deal with non-state actors have highlighted the interaction with formal institutions but have come to diverging conclusions with regard to the effect of local elites on the statebuilding process.

Early peacekeeping and statebuilding studies usually did not account for a 'local level'. Many scholars of statebuilding have operated on the assumption that interventions will occur in an anarchical environment (Kaplan 1994). In this view, civil war destroys almost all social structures of an affected state and, therefore, statebuilding can start from a clean slate. Policebuilding takes central stage in efforts to regulate small-scale violence, and a quick deployment of police is deemed necessary to fill the void of post-conflict societies. "Societies emerging from war face a variety of threats from extremist and criminal organizations. Indigenous capacity to meet these challenges is almost always inadequate and sometimes nonexistent" (Dobbins 2007: 48). In this context, some scholars have argued that SSR was the right strategy to address political issues as it combines policing with liberal institutional solutions. For example, Marenin (2005: 123) argues that "SSR points to the systemic connections of the police to wider security concerns; it stresses the inherently political nature of trying to reform policing systems, especially by the notions of democratic control and good governance; and it points to the importance of rights as a counterbalance to demands for security in a democratic system". However, these approaches have rarely asked whether there is unequivocal support for democracy and good governance at the local level. Manning was one of the first to highlight that the implementation of post-conflict policies at the community-level often depends on the cooperation of local elites (Manning 2003).

As more recent research has shown, the collisions of externally sponsored formal institutions and local structures have led to unintended outcomes. Instead of leading to either the persistence of the local structures or the creation of liberal institutions, the outcomes are hybrid orders that combine both elements (Mac Ginty 2011). "The hybrid peace is a result of a series of distortions and reminds us of the lack of autonomy on the part of actors in peacemaking contexts" 
(Mac Ginty 2010a: 392). Such 'hybrid outcomes' have been criticized on the grounds that local institutions are a source of instability and conflict. In this view, local elites act primarily as spoilers who sabotage the expansion of state powers in order to keep their rent-seeking opportunities (Stedman 1997). The local institutions which empower these actors are seen as illegitimate as their rules are not issued by democratically elected bodies, not everyone has the same rights (or status) within the community, and elites are often not cons trained by formal rules (Gerdes 2013a). For example, Denney (2013: 13-14) argues that "[the] chieftaincy system in Sierra Leone has instituted some highly oppressive practices and maintains a discriminatory justice system that frequently disregards the rights of women, young people and other vulnerable groups". Hence, some have concluded that these institutions will produce grievances that increase the likelihood of renewed conflict (De Waal 2009: 106 ; Richards 1996).

In contrast, others have pointed out that local institutions are usually seen as legitimate by their populations (Lake 2010b). Local elites are in direct contact to their constituency and have to provide security. The power of local elites derives from their ability to take care of communities and also to represent the interests of the community vis-à-vis the central government (Abrutyn and Lawrence 2010). According to Boege et al (2008: 9) "[..] it is the community that provides the nexus of order, security and basic social services. People have confidence in their community and its leaders, but they have no trust in the government and state performance". The legitimacy of self-help communities has often developed over decades or centuries (Boege et al. 2008: 7-8). Autessere (2010: 270) argues that for statebuilding to succeed, "[having] village- or district-level authorities whom local populations accept and consider legitimate will help ensure that state authority extends beyond the provincial capitals". Many of the local institutions that interact with statebuilding can be classified as self-help communities. Compared to these institutions, state policing can appear to be ineffective, detached from the population, and thus unaccountable. Police forces are often the most corrupt of all state institutions, as their position is quite unique: They are armed, enjoy great discretion in everyday operations and are in close contact with the population. Furthermore, despite efforts to reform recruitment, police offices often become bargaining chips for governments that seek the loyalty of local elites. Hence, a patrimonialization of police forces is often the outcome of statebuilding efforts ${ }^{16}$. Thus, central to efforts to reform

\footnotetext{
${ }^{16}$ For example in Afghanistan (Giustozzi and Isaqzadeh 2013: 119-120); East Timor (Radin 2012: 20-21); Sierra Leone (Baker 2008: 140-141)
} 
justice and law enforcement in post-conflict societies is the fact that a change in these societal areas implies a significant shift in power (Berg 2012). For example, Jackson (2011: 1810) argues that "[at] the heart of SSR are the core values of democracy, good governance, gender equality, transparency and accountability, as well as a desire to propagate universal human rights. This not only brings SSR into direct conflict with some proposed local owners who may not want all of these things, it also represents a strong allegiance to the liberal peace-building project". Thus, the insistence of external actors on a specific form of political institutions combined with state policing ignores the de facto political realities in a society. Those actors who would lose power are thus very likely to oppose changes. Hence, Barnett and Zürcher (2009) argue that local elites will seek to retain their autonomy, and they use their power to bargain both with external actors and the central government to defend the status quo.

The bottom line of this review is that the efforts of statebuilding interventions to monopolize the regulation of small-scale violence often collide with existing self-help communities. On the one hand, interventions build police forces according to Western principles of organization. On the other hand, local institutions often remain in place despite the expansion of state policing. The local elites that control small-scale violence regulation make use of their power to influence national politics in order to safeguard their self-help communities against the central government's monopolization efforts. However, while this explains the failure of statebuilding interventions to a certain degree, it cannot properly account for the successful cases.

\section{The Regulation of Small-Scale Violence in Statebuilding Interventions}

Based on combining the insights from the state formation and statebuilding literature with my findings from the case studies, I put forward my main argument with regard to small-scale violence. Statebuilding is an effective way to build modern police forces and to create formally liberal institutions in post-conflict societies. However, a history of weak statehood will trigger the weak state legacy mechanism. Statebuilding interventions will fail to create a monopoly on smallscale violence regulation in societies that never had a strong state. In contrast, a history of strong statehood prior to the crisis will trigger the strong state legacy mechanism, causing statebuilding interventions to succeed in creating a monopoly on small-scale violence regulation. The next paragraphs will detail my reasoning. 
The state monopoly on the regulation of small-scale violence consists mainly of two elements. On the insitutional side, the state is present at the local level across the territory, and society is regulated exclusively by state law. On the organizational side, bureacratically controlled police forces are the major tool to police society and enforce state laws. In countries where the state has not monopolized the regulation of small-scale violence regulation, self-help communities fulfill this task for a great share of the population. Self-help communities provide an atlernative set of rules and rule enforcement at the local level. To achieve a state order, the government has to engage in a monopolization process that entails the replacement of self-help communities by a state policing system under a unitary legal framework. In state formation, this process usually takes decades and entails a habituation of the population to state rule.

These basic theoretical considerations have implications for statebuilding interventions. In the previous sections I have argued that the main focus of statebuilding is on the establishment of formal institutions and the strengthening of organizational capacities in form of professional, bureaucratized police forces. In states with a history of strong statehood, there are no self-help communities and the population has been socialized into accepting state order as the only reasonable way to regulate small-scale violence. Furthermore, the power of local elites does not depend on non-state institutions. Therefore, statebuilders efforts to re-construct the state monopoly on small-scale violence regulation will be met with little resistance.

Traditionally weak states offer a very different picture. In these states, self-help communities have developed that are well-entrenched at the local level and cannot simply be replaced by state institutions. In the following, these existing institutions will be theorized as legacies of the long-term state formation process ${ }^{17}$. The view that the longue durée of history creates structures that can outlast short-term cyclical events is well-established in the social sciences (Braudel 1958). Political institutions that have developed in the long-term process of state formation create strong path dependencies that will structure power relations even during critical junctures such as regime changes or civil wars (Kitschelt 2001: 307-311; Pierson 2004). Through these legacies, the historical state formation acts as a 'remote cause' for the outcomes of statebuilding (Schneider and Wagemann 2006). Since they outlast such events as civil wars, selfhelp communities are in place at the beginning of statebuilding interventions. Any new

\footnotetext{
${ }^{17}$ I borrow the term from Kitschelt who could show that the institutional set up in post-Soviet countries was strongly affected by their pre-Soviet regime (Kitschelt 2001: 299-300).
} 
government will have to rely on those local elites who control local non-state institutions. Therefore, local elites become very powerful in the statebuilding project and have strong incentives to block monopolization efforts. As a result, the statebuilding intervention creates state capacities (especially in the form of police forces) without actually disbanding self-help communities. The result is a para state that is characterized by legal pluralism and competition between police and non-state rule enforcers.

Empirically, Afghanistan and Sierra Leone never had a strong state that could have replaced the self-help communities. Whereas Sierra Leone displayed a rather wellinstitutionalized chiefdom system that regulates small-scale violence in most parts of the country, Afghanistan was more heterogeneous. Especially due to several decades of civil war and internal displacement, self-help communities have developed a great variety of forms (such as traditional tribal communities as well as militarized mujahedeen commander communities). Thus, in both cases the statebuilding efforts were confronted with the existence of self-help communities. At the early stages, local elites captured parts of the statebuilding process. In Sierra Leone, the government depended on the support of chiefs and, thus, the chiefdom system remained in place. In Afghanistan, there were no officially acknowledged self-help communities, but local elites kept in de facto control over small-scale violence regulation. Thus, the statebuilders created new institutions and build modern police forces without abandoning self-help communities. As a result, the outcome of both cases was a para state. In contrast, Bosnia-Herzegovina has a long history of strong statehood during which small-scale violence monopolization already began in

the late $19^{\text {th }}$ century. Thus, at the end of the war there were no well-institutionalized alternatives to bureaucratized policing. The statebuilding intervention demilitarized Bosnia's society and reconstructed a state monopoly on small-scale violence regulation. Figure 6 and 7 show the causal mechanisms developed through the case studies.

\section{The Weak State Legacies Mechanism}

In countries with weak state legacies, statebuilding interventions will most likely fail to monopolize the regulation of small-scale violence in the hands of the state. The overwhelming majority of countries ridden by civil war are post-colonial states that never had a strong central government or sophisticated state infrastructures. Thus, the weak state mechanism is the one most 
likely to be observed in statebuilding interventions. It consists of three parts that are triggered by the initial condition of weak statehood prior to the crisis that triggered intervention.

\section{The Weak State Legacies Mechanism}

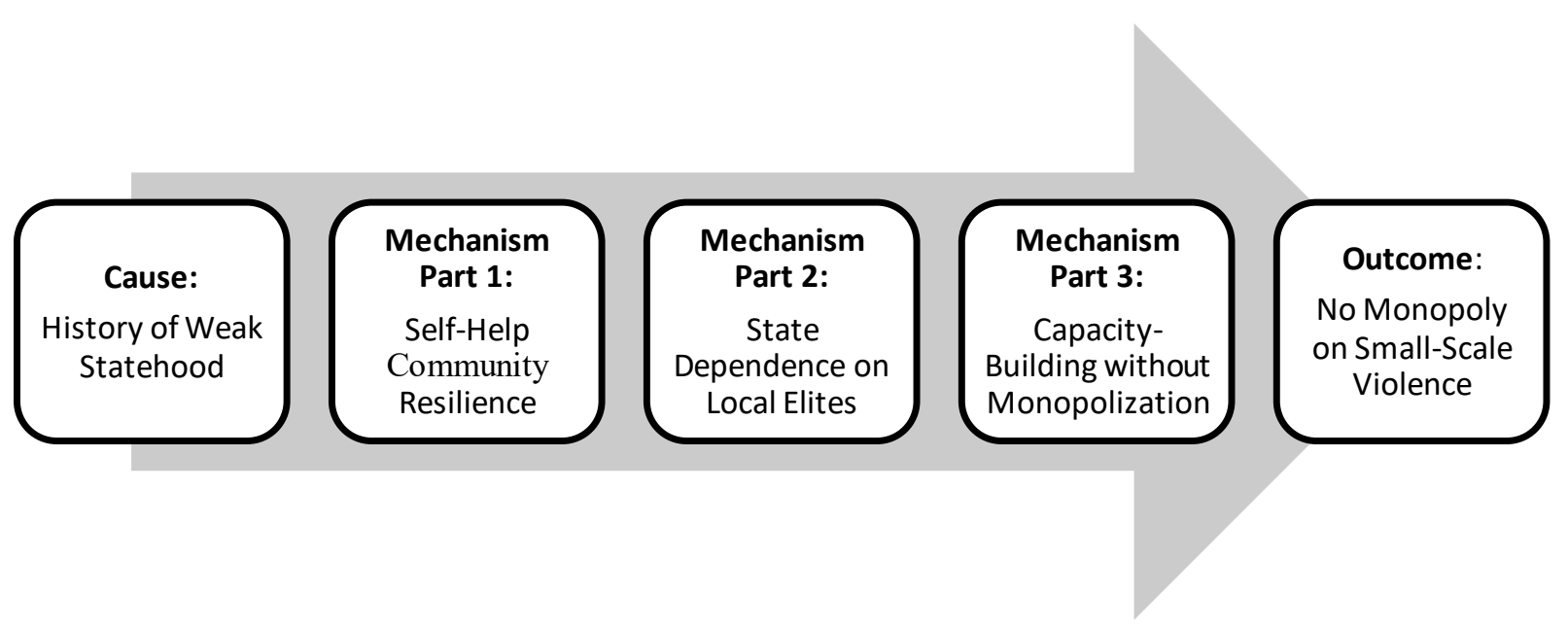

Figure 6: The weak state legacies mechanism.

The long-term absence of a strong state causes local communities to develop their own institutions to regulate small-scale violence. Prior to the crisis that leads to intervention, a large portion of the population is governed by self-help communities, whereas state policing is weakly developed. Local institutions produce local elites which are highly powerful compared to the central government which often lacks the social ties in rural areas.

(1) Self-Help Community Resilience: The first part of the mechanism concerns the resilience of institutions that regulate small-scale violence. When a crisis such as a civil war occurs, self-help communities remain intact during the conflict because they are well-institutionalized and do not depend on the central government. While they might be drawn into the conflict, they mostly continue to regulate small-scale violence at the community level. Thus, at the time of intervention self-help communities and local elites have gained power compared to the government which resides over a greatly weakened state.

(2) Government Dependence on Local Elites: In step two, at the beginning of the statebuilding intervention, the central government is weak while local elites (whose 
power stems on the self-help communities) are strong. At this point in time, capacitybuilding has not started yet and the government depends on the support of local elites which can provide stability and security.

(3) Capacity-Building without Monopolization: Step three of the mechanism entails the main part of statebuilding, namely the capacity-building through SSR. The central government is provided with a strong police force. However, the local elites have entrenched their power either through early formal acknowledgement or by capturing formal institutions at the local level. The self-help communities remain in place.

The outcome is a form of para-statehood in which small-scale violence is regulated by competing institutions. Since the goal of interventions is the creation of liberal statehood, including a full monopoly on violence and governance bound by the rule of law, para-statehood is seen as a failure of intervention by policy-makers. While the effect of deeply rooted social structures on statebuilding makes the limitations of these missions apparent, a failure to liberalize statehood can nevertheless also have stabilizing effects.

In cases where strong local institutions block monopolization efforts, the question will be how the statebuilders deal with self-help communities. Two strategies are conceivable: One approach would be to officially ban local institutions and force the population to accept formal state institutions. Another approach would be to accept the existing of self-help communities and bind them institutionally to the state.

\section{The Strong State Legacies Mechanism}

States that have developed strong institutional structures are less affected by civil wars, but they are not immune to internal armed conflict. Statebuilding interventions in these societies are likely to establish a state monopoly on small-scale violence, because they can reconstruct formal institutions and organizations in a society that has accepted this mode of governance as the norm. While they are very rare, interventions into societies that had strong statehood before the crisis have occurred for example in the Balkans. Under these conditions, the presumptions of SSR (with regard to small-scale violence) are correct and the intervention techniques do work. 


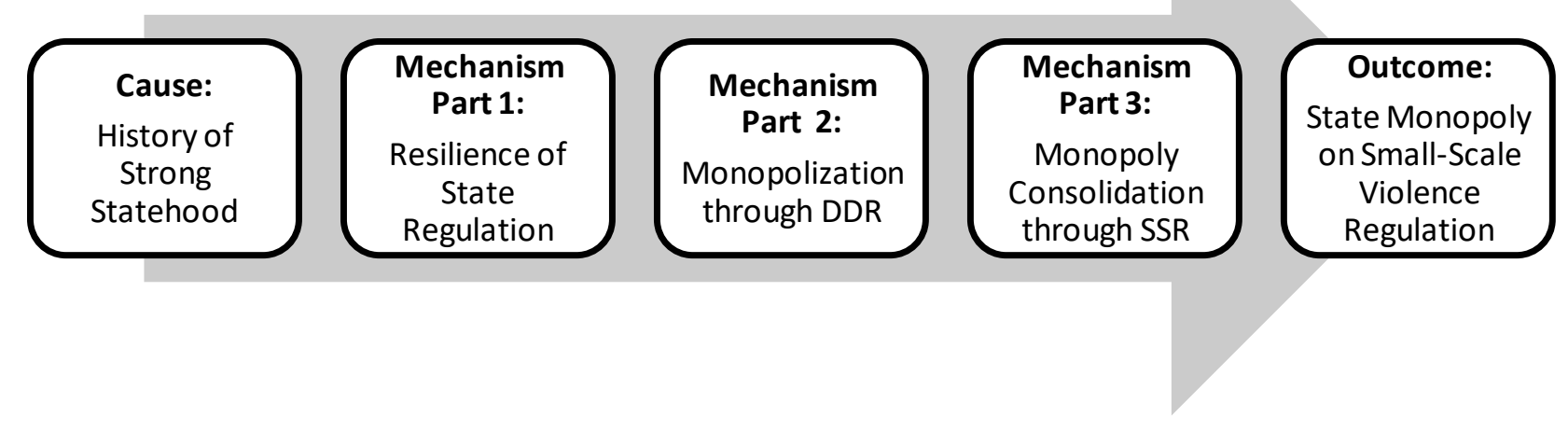

Figure 7: The strong state legacies mechanism.

The strong state mechanism is triggered in cases of statebuilding intervention where there has been a modern state prior to the crisis. In these cases, the country has been governed by bureaucratic state institutions that had monopolized the regulation of small-scale violence. Whether the state as such existed at this point in time, or whether it was part of a larger state, is not relevant for the mechanism. What matters is that in these societies, the state has been present in people's life both by providing public goods as well as by 'disciplining' them in school or the military. Thus, self-help communities have been replaced by state agencies, and local elites (if present) lack a strong local powerbase. Put differently, the state's claim on regulating small-scale violence was well institutionalized prior to crisis.

(1) State Resilience: The first step of the mechanism is triggered when civil war breaks out. As the monopoly on large-scale violence collapses, armed groups take control of different swaths of territory. Where armed groups have zones of control, they leave the bureaucratic structures in place. Hence, 'state' policing continues under the new rulers because it is well institutionalized at the local level. During this period police forces can be militarized and be used for counterinsurgency purposes, i.e. the organizational quality of police forces might deteriorate. Nevertheless, the institution of state(-like) bureaucratic policing remains in place during conflict. 
(2) Monopolization: In step two, the statebuilding intervention monopolizes small-scale violence regulation. Formal institutions are introduced that provide a liberal legal framework for the regulation of small-scale violence. Small-scale violence actors that have spread during conflict are disarmed. The monopolization is effective because there are no strong non-state institutions and, therefore, no non-state elites that would be powerful enough to obstruct the process.

(3) Consolidation: In a third step, the statebuilders consolidate the state monopoly on smallstate violence regulation through the provision of funding, training, and equipment for the police, and they set incentives for the state to reform its police structures. A modern police organization is formed and deployed across the territory.

The outcome is a state monopoly on the regulation of small-scale violence. As the causal mechanism shows, the institution of state policing never completely disappears, although it might be strained during the conflict. There are no self-help communities that could provide the population with alternatives systems of rules and rule enforcement. Hence, there are also no strong local elites that could block the process of reinstating state policing. In cases where the monopolization of large-scale violence did not succeed, the outcome is likely to be the same: Bureaucratic police forces can be rebuilt and strengthened, but ultimately are controlled by two or more macro level entities.

\section{Conclusion}

Statebuilding interventions aim to create liberal statehood, and state regulation of small-scale violence is a core feature of the liberal order. Thus, interveners embark on expensive policebuilding missions embedded into wider institutional reforms. More ambitious goals such as the liberal rule of law are only conceivable once the regulation of small-scale violence is controlled by the state. As the chapter has argued, the template that intervening actors use to achieve this goal is very similar across different contexts. The focus is on formal institutions and organizational capacities, especially in terms of building a professional police force. Yet, the conditions that determine whether a certain strategy will succeed or fail vary starkly across cases. Interventions have occurred in well-developed regions such as former Yugoslavia as well as in 
some of the poorest, weakest states of the world such as Afghanistan or Sierra Leone. As I tried to show, the outcome of statebuilding interventions depends on the long-term institutionalization of small-scale violence regulation in a given country. As institutions create strong path dependencies, neither civil wars nor statebuilding interventions are likely to radically alter these social structures within a short time period.

The implication of this finding is that most statebuilding interventions will lead to the establishment of 'para statehood'. Local elites and non-state institutions will be somehow integrated into the larger state structures but retain a large degree of autonomy. If the benchmark of intervention is the set of goals formulated by those actors who conduct statebuilding, this outcome is disappointing. Instead of liberal statehood, the intervention (re-)creates a neopatrimonial system in which local elites can sustain local institutions that operate non-liberal legal systems and cannot be properly controlled by the government. Furthermore, the strong position of local elites carries the risk of coalitions against the government that could de-stabilize the state in the future.

\subsection{Conclusion}

The monopolization of violence is a fundamental element of statebuilding interventions, but it has produced greatly varying outcomes. Given that the interventions were conducted by a similar set of actors with similar strategies and amounts of resources, the pattern of outcomes is puzzling. Based on the distinction between large-scale violence and small-scale violence, this chapter has forwarded an explanation for the varying outcomes of statebuilding. So far, this distinction has been made by few scholars, and Security Sector Reform approaches have been blind to the distinctive logics of violence at the two levels. Once this analytical distinction is adopted, it is possible to distill the conditions under which statebuilding will succeed or fail to institutionalize state regulation of violence. As this chapter has argued, two conditions need to be met for statebuilding interventions to succeed: First, the intervention needs to be supported by key regional actors. Second, the target society has to have experienced a history of strong statehood prior to the crisis that triggered the intervention. Only when both conditions are in place can statebuilding interventions lead to a full monopoly on violence. 
The argument in the case of the regulation of large-scale violence was that the focus on domestic factors to explain monopolization outcomes is insufficient. Instead, we need to shift attention to the regional level and ask in how far statehood has been institutionalized in the wider region. Where external actors deploy a large number of troops, conduct DDR and SSR programs, and commit themselves for a period of several years (see definition above), the support or opposition of regional becomes the crucial condition that determines whether a monopoly on large-scale violence can be achieved. I argued that the causal chain linking condition and outcome concerns the capacity of armed groups to wage war, as these actors can only resist superior Western interventions when they have the support of regional actors. Where regional actors support the intervention, statebuilding proves to be a successful tool of monopolizing the means of warfare in the hands of a (democratically elected) government.

In contrast, the regulation of small-scale violence hinges on the degree to which local communities have developed the capacity to set out rules that are accepted by their members and enforce them effectively. Given the separate treatment of these two types of violence, the theory of intervention and violence regulation laid out so far begs the question how the two levels interact with each other. There are two answers to this: For state formation in general, the interaction effects are of great importance. For statebuilding interventions in particular, the influence of one dimension on the other is rather limited.

\section{Monopoly on Large-Scale Dispersed Means of Violence Large-Scale Violence}

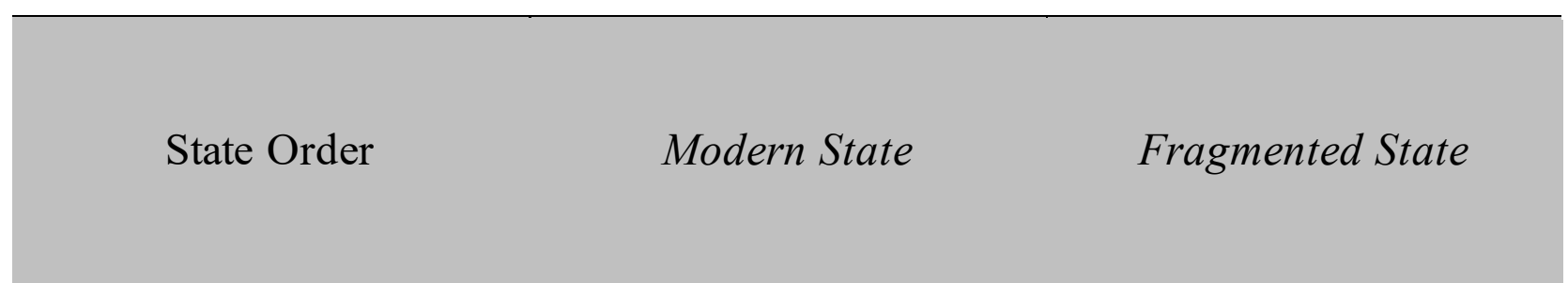


Given the separate explanations I offer for the two types of violence regulation, the question arises the regulation of large-scale and small-scale violence are related. My argument is that they are largely de-coupled in current statebuilding interventions. The last chapter has argued that the two emerged in a sequence but were also highly intertwined in historical state formation. Governments monopolized the means of warfare first, but in order to defend their monopoly against outside threats they had to increase tax revenues and mobilize their populations. Hence, they engaged in statemaking: They built local administrations and bureaucracies, developed modern police organization, indoctrinated the population in schools and through military services and weakened local elites (Tilly 1992: 114-116). Although statebuilding interventions are a very specific form (i.e. a subset) of state formation (Bliesemann de Guevara 2012: 4-6), such a protracted, long-term statemaking process is far beyond the time horizon of statebuilding interventions.

In statebuilding interventions, the creation of a monopoly on large-scale violence does not depend on the monopolization of small-scale violence regulation. As the weak state legacy mechanism implies, neither external actors nor the central government are likely to engage in the aggressive disempowerment of self-help communities. Statebuilding greatly reduces one major difficulty of monopolization, namely the buildup of organizational capacity (Tilly 1992: 68-70). Through an inflow of funding, training, and equipment, the newly established polity can quickly acquire modern armed forces and police. Thus, the newly built state does not need to aggressively expand its tax base and exercise greater control over the local level. These current practices of statebuilding favor an accommodation of local elites. Put differently, the government no longer needs to develop vast extractive capacities to build armed forces and police forces as the necessary resources are provided by external actors (Bliesemann de Guevara 2012: 7-11 ; Schlichte 2005b: 182-221). Therefore, although the resulting para statehood implies reduced revenues and the long-term risk of renewed rebellion by alliances of local elites, a monopoly on large-scale violence can exist without a monopoly on small-scale violence regulation.

While it is easy to imagine that a monopoly on small-scale violence regulation is no necessary condition for a monopoly on large-scale violence, the opposite appears to be more difficult. Small-scale violence regulation is affected by large-scale violence regulation in limited 
spatial areas. As argued above, where either the government or armed groups have full control over territory, the determining condition for small-scale violence regulation will be whether there are strong self-help communities in place or not. For example, during the war in Ukraine in 2014 control over the city Sloviansk changed at least two times between government and rebels. A certain number of desertions notwithstanding, state-centric small-scale violence regulation remained in place throughout the conflict (NYTimes 2014a). However, in fiercely contested areas where large-scale violence actually erupts, self-help communities as well as police forces are often exploited for the broader war effort (Kalyvas 2008: 111-115). In these zones, small-scale violence regulation can collapse temporarily. Nevertheless, in most areas most of the time smallscale violence regulation is not greatly affected by the actors who control the means of largescale violence.

Based on the model presented in this chapter, the following chapters analyze the cases of Afghanistan, Sierra Leone and Bosnia-Herzegovina. They show how statebuilding interventions have succeeded and failed to monopolized violence regulation in post-conflict societies. 


\section{Afghanistan}

The liberal statebuilding intervention in Afghanistan was perhaps the most ambitious statebuilding intervention that was ever conducted. It was the embodiment of mission creep: What began as a light foot print mission in 2002 transformed over the years into the second biggest military interventions of the post-Cold War era ${ }^{18}$. With close to 150,000 troops and billions of dollars of aid money, NATO tried to build a modern state in Afghanistan. It was meant to become secure, governed by democratic principles and the rule of law, and on the track of economic development. Yet, in 2014, while NATO was shutting down its International Security Assistance Force (ISAF), the country performed badly on almost all indicators. Regarding the institutionalized control of violence, the intervention has neither created a state monopoly on large-scale violence nor on small-scale violence regulation. This chapter argues that the intervention failed to create a monopoly on large scale violence because of an unfavorable regional political system, and it shows that the long-term absence of a strong state led to a failure of monopolizing small-scale violence regulation.

With regard to the monopoly on large-scale violence, the argument is that the security competition between two key regional states, India and Pakistan, has prevented ISAF from succeeding. While India supports the pro-Western Afghan government, Pakistan supports the Taliban insurgency. The chapter shows that the regional competition mechanism outlined in chapter three can explain who regional politics caused statebuilding failure in Afghanistan. Since Pakistan granted the armed groups of Afghanistan access to its territory, the Taliban and its allies could resist monopolization efforts. Due to this transnationalization strategy, the armed group could prolong the conflict and drive up monopolization costs to such an extent that the intervening actors aborted the mission despite an ongoing civil war.

In contrast, the cause of ISAF's failure to monopolize small-scale violence regulation is more remote. The long-term absence of a strong state in Afghanistan has created legacies in the form of strong self-help communities and powerful local elites (mujahedin commanders, tribal leaders, village elders, etc.). These communities have outlasted the twenty years crisis that has preceded the Western intervention and were thus able to shape the statebuilding process early on.

\footnotetext{
${ }^{18}$ The coalition in Iraq deployed over 170,000 troops at the height of the occupation.
} 
From its inception the Karzai government depended on the cooperation of local elites who had little interest in letting the state replace their powerbases with formal institutions and bureaucratized police forces. As a result, Afghanistan is a para state, i.e. a state in which self-help communities continue to play a decisive role and where state institutions of small-scale violence regulation (e.g. local government, police offices) have been captured by local elites.

Before going into the detailed case study, it is necessary to check the plausibility of case-specific alternative explanations. A major rival explanation for ISAF's failure of violence monopolization has been the thesis that the intervention has put too little emphasis on inclusion and reconciliation. In this reading, the focus of the US and later NATO on warfare has caused the armed groups to grow stronger and eventually undermine the newly established state (Sedra 2013; Suhrke 2012). Suhrke (2012) sees a major contradiction between the use of force on the one hand and building a peaceful Afghanistan on the other. By concentrating on stability and fighting the Taliban, the intervention squandered good governance and justice, increasingly causing Afghans to turn against ISAF (Suhrke 2012: 485-487). There are several reasons for why this argument cannot explain ISAF's failure to establish a monopoly on large-scale violence. First, the evidence presented in this chapter shows that the Taliban first expanded their military presence and only afterwards did NATO respond. Armed groups were especially successful where there was neither ISAF nor Afghan National Army (ANA) presence. Second, the state formation literature discussed in chapter two shows that the monopolization of violence is itself often a violent process. There is little reason to assume that a promotion of good governance can succeed before the state's monopoly on large-scale violence. Third, in comparative perspective the explanation appears implausible. As the next chapter will show in detail, the UN's coercive disarmament of the RUF in Sierra Leone did not create resentment but became the basis of its popularity in the West African country. Others have focused on the fact that the statebuilding intervention started off as an alliance with the warlords of the Afghan North (Mac Ginty 2010b). However, this chapter shows that the dissolution of the warlord armies (Afghan Military Force, AMF) and their integration into the formal army are one of the successes of the otherwise failed monopolization process. Furthermore, Hamid Karzai's tribal networks also integrated warlords and strongmen of the South into the state and security forces. 
One popular counter-argument is that Pakistan is not able to control its border (Saikal 2006b: 137-138). In such a reading, Pakistan is not a regional power pursuing its interest but a weak state unable to challenge the armed group operating on its soil. However, as I make clear in the discussion of Pakistan's policies, the weak state hypothesis is not convincing. Except for the Federally Administered Tribal Areas (FATA), Pakistan rules most of its provinces bordering Afghanistan directly (including Khyber Pakhtunkhwa ${ }^{19}$ ). Furthermore, the most important Taliban hub is not the FATA but Quetta and the surrounding Belochistan province. While Pakistan has done nothing to confront the Afghan Taliban or the Haqqani Network, it has waged an intense counterinsurgency campaign against the Pakistani Taliban. In sum, the evidence I present throughout the sub-section on the monopolization of large-scale violence strongly suggests that Pakistan actively supported the Afghan Taliban.

The failure of the intervention to create a state monopoly on small-scale violence has been attributed to the paramilitarization of police training after the return of the Taliban (Friesendorf 2011). While it is true that the later recruitment of 'trigger pullers' has undermined the quality of the Afghan police, there are several reasons why this hypothesis does not fully explain the monopolization failure. First, under Germany's leadership police training was focused largely on creating a strong professional leadership that could transform policing in Afghanistan. During this period, no gains were made in terms of replacing local elites with professional ANP forces. Second, the argument does not hold in comparative perspective as the case of Sierra Leone has shown that even a well-planned, quality-oriented police training mission will not replace self-help communities. In a nutshell, the paramilitarization argument focuses too much on the technicalities of policing and ignores the political dimension of small-scale violence regulation.

The chapter will briefly outline Afghanistan's history of state formation and civil war prior to the intervention. Afterwards, it provides an explanation for the failure to monopolize the two types of violence regulation.

\footnotetext{
${ }^{19}$ Formerly known as Northwestern Frontier Province (NWFP).
} 


\subsection{State Formation and Civil War in Afghanistan}

In 2002, NATO entered a country that had been devastated by decades of civil war. Afghanistan had suffered much more than either Bosnia-Herzegovina or Sierra Leone as it has been the scene of two successive civil wars. Between 1979 and 2001 armed factions fought each other at varying degrees of intensity. However, before this period Afghanistan had experienced a long period of relative stability and state formation. This chapter shows that an Afghan state was slowly taking shape since the $19^{\text {th }}$ century. Unlike some characterizations of Afghanistan as a chaotic crossroads where tribes rule and empires die, this chapter shows that successive central governments have succeeded in slowly but steadily monopolizing the means of coercion. Nevertheless, it is also necessary to point out that the eventual collapse of the state and the Soviet intervention were direct consequences of the modernization process that occurred in mid- $20^{\text {th }}$ century Afghanistan.

\section{State Formation before the Civil Wars}

\section{Early State Formation}

The area that is today's Afghanistan was for most of its history part of empires. After a series of revolts against the Persian Empire in the early $18^{\text {th }}$ century, Kandahar became a focal point of Afghan state formation (Schetter 2003: 194-197). In 1747, Ahmed Shah took advantage of the situation created by the murder of the Persian ruler and became the new strongman in Kandahar. He founded the Durrani dynasty by uniting local tribes and conquered large swaths of territory, including most of the areas of modern day Afghanistan (Rubin 1995: 45-46). Ahmed Shah Durrani is still seen as the founding father of the Afghan nation. However, his rule was based on the patronage of tribal elites and the Durrani nobility, and he did little to institutionalize the rule. His main tool to keep his empire together was his personal army (Schetter 2003: 199-204). Under his successor in 1776, Kabul became the capital of the Pashtun kingdom due to civil war that threatened Kandahar (Schetter 2003: 204-205). However, the capital would change several times in the subsequent centuries. Nevertheless, before it fell apart in 1801, the Durrani dynasty was 
arguably central to the emergence of Afghanistan as a state, although there would be no sustainable institution-building until the early $19^{\text {th }}$ century.

Due to the expansion of Russia and the British Empire in Central Asia, the Pashtun kingdom became part of the so-called 'Great Game' between the two great powers during the $19^{\text {th }}$ century. While the Afghans won their first war against the British Empire (1839-1842) in the 1830s, the second war (1878-1880) ended with a deal which gave Britain de facto control over Afghan foreign policy (Schetter 2003: 216-217). While Emir Abdu Rahman accepted this condition during his reign from 1880 to 1901 , he nevertheless tried to build a state within the borders the Empires had forced him to accept. His vigorous efforts to unify and modernize Afghanistan brought him the byname "Iron Emir". He weakened the tribes, built the first modern bureaucracy, and sought the establishment of a nation state. In contrast to earlier monopolization efforts, Abdur Rahmans rule was the first major statebuilding effort (Schetter 2003: 220-223).

\section{Building a Modern State}

During his reign, the British Empire and Russia negotiated and eventually agreed on most of the borders of the Afghan state ${ }^{20}$. As Cullather (2002: 515) argues, "Afghanistan, at its origin, was an empty space on the map that was not Persian, not Russian, not British[..]". Especially the border with British-India, the Durand-Line, was drawn arbitrarily through all kinds of tribal and ethnic territories. This laid the foundation for future border disputes with Pakistan. However, with the shift from ruling over tribes to ruling over the population of a fixed territory, Abdur Rahman began a campaign to unify the country. In over forty military encounters he enforced state rule and tried to dissolve non-state political structures. State administration was extended to the local level, thereby weakening tribal leaders (Schetter 2003: 222-230). Lacking an Afghan national identity, Rahman resorted to Sunni Islam as the one unifying ideology that differentiated Afghanistan from its neighbors. Rahman described his effort in terms that resemble European state formation as much as the challenges Karzai is facing in $21^{\text {st }}$ century Afghanistan:

"I had to put in order all those hundreds of petty chiefs, plunderers, robbers, and cutthroats, who are the cause of everlasting trouble in Afghanistan. This necessitated

\footnotetext{
${ }^{20}$ The border with Persia was delineated in 1904.
} 
breaking down the feudal and tribal system, and substituting one grand community under one law and under one rule." (Schetter 2003: 221)

This statement of a statebuilder captures a central element of Afghan social structure. In this poor, agricultural society, the only resource surpluses were generated in cities such as Kandahar. This allowed for social stratification and, thus, larger scale political rule. However, while there was some hierarchy in the Pashtun macro tribes that ruled Afghanistan, most governance occurred at the local level (Schetter 2003: 214-216). Life was centered on local customary law and (Sunni) Islam, and the latter was arguably the only idea that created something close to a collective identity (Schetter 2003: 230-233). Ethnicity did not play a role until the mid-20 ${ }^{\text {th }}$ century. When the centralization process began, there was no such thing as an Afghan national identity. The decentralized power structure created strong centrifugal tendencies against which Abdur Rahman and his descendants had to mobilize their scarce resources.

His successor Amanullah decided to seek full independence from the British in 1919. While the Afghans were militarily beaten in the Third Anglo-Afghan War (1919), the British wanted to avoid further warfare and thus agreed to sign the Treaty of Rawalpindi, granting Afghanistan full control over its foreign affairs. The signing of the treaty on 20 August 1920 is seen by Afghans as their independence day. A period of radical modernization followed in which Amanullah gave Afghanistan its first constitution (1923) and sought to transform it into a modern nation state. He proclaimed that his power derived from 'the nation' instead of Islam, his constitution sought equal rights for Muslims and non-Muslims, and he wanted to liberalize gender relations. This led to a massive backlash by the tribes, which ousted him in 1929 (Rubin 1995: 54-58).

The first army in a modern sense was created by Nadir Shah after he seized Kabul in 1929, with about 40,000 troops (Cullather 2002: 518). In a somewhat Prussian fashion, the army during Shah Zahir's rule was meant to integrate the national elites into the state. To achieve this goal, "[..] the Afghan army was subordinated to the executive authority through the appointment of aristocrats as generals; since all key positions were controlled by aristocrats, the loyalty of the army should have been ensured" (Giustozzi 2011b: 8). Great steps in enlarging and modernizing the army were taken by successive governments between the 1950s and the beginning of the civil war. Due to the US alliance with Pakistan, Afghanistan sought a stronger partnership with the 
USSR and received large amounts of military aid and training. During this period, the force was for the first time equipped with modern technology. Afghanistan received tanks, helicopters and planes from the Soviets, and a whole generation of officers was trained in Russia (ICG 2010a: 34). The professionalization came at a high price, as it were these Soviet-trained officers who would eventually stage a socialist coup in Afghanistan in 1978.

\section{The Socialist Statebuilding Experiment}

A coup by the communist People's Democratic Party of Afghanistan (PDPA) in 1978 overthrew the young republic and led to a period of radical social reform. Reforms ranged from land reform to a re-definition of gender norms. This revolution from the top was met with fierce resistance from the local level, leading to the development of anti-government forces that rallied behind the banner of Islam. It was the first real test for the Afghan army, and the armed forces largely failed the test. Only one year into the war, and with substantial Soviet backing, the mutiny of one division in Kandahar almost led to a total collapse of the army (ICG 2010a: 4). In order to prevent the collapse of the regime, the USSR militarily intervened in Afghanistan in December 1979 and started a socialist statebuilding intervention. The result was an internationalized civil war in which armed groups who called themselves mujahedin and were supported by Pakistan, Arab states, and the US fought against the central government and the Soviet army. As in many civil wars, the Afghan-Soviet War displayed strong centrifugal forces that led to a decentralization of the means of violence. The government increasingly armed militias in order to contain the spreading insurgency. Young men fought in great numbers in the armed forces, progovernment militias or mujahidin groups. "While an estimated 262,000 had served in progovernment militias or the official army by 1988, mujahidin forces reached nearly 340,000 personnel by 1991" (ICG 2010a: 5).

Militias and mujahedin were incorporated into the armed forces in order to co-opt them into state structures. As a consequence, "[the] Afghan security force, while growing substantially, became increasingly 'tribalized', resembling less of a professional military force and more of a loose coalition of tribal forces brought together by material payoffs and other inducements" (Hess 2010: 179). However, the government could not pay for these expenses and was heavily dependent on Soviet money, supplies and arms (Rubin 1995: 148-149). The Najibullah 
government survived a mujahedin offensive in Eastern Afghanistan in 1989, and two coup attempts by Kalqhi party members and Hekmatyar in 1989/1990 (Rubin 1995: 151-152). Nonetheless, once Russian support was terminated in 1992, the neopatrimonial system collapsed, the armed forces fragmented into regional warlord fiefdoms, and eventually Afghanistan would slide into civil war (Rubin 1995: 269-271).

To sum up, it would be too easy to claim that Afghanistan could never be ruled by a central government. Since the late $19^{\text {th }}$ century, Afghan rulers have embarked on a statebuilding project that accumulated power over decades. As a state emerging in a globalized world, all Afghan rulers had to deal with great powers from the British Empire to the Soviet Union, and they always managed to acquire some external support for their institution-building measures. Before the revolutions, the government had a quite modern army which was instrumental to keeping up internal order. The police force was slowly modernized and often acted rather as a canary in the coal mine. However, the state never played an important role in the life of the great majority who lived in rural Afghanistan. Thus, the state lacked deep roots in Afghan society. With the onset of radical reforms by the socialist government and the interference of the USSR, the US and Pakistan, the fragile achievements of almost a century of state formation were destroyed. When the Najibullah regime collapsed, the institutions of the state fell apart.

\section{Civil War and the Rise of the Taliban}

The Afghan civil war resulted from a power-sharing arrangement in 1992. Different mujahedin factions and former army commanders brought their forces close to the capital as negotiations were brokered by the UN. After the fall of the Najibullah regime in April 1992, the major warlords had agreed on a shared occupation of Kabul (Peshawar Agreement) and declared the Islamic Republic of Afghanistan on 28 April (Rubin 1995: 271-272). Rubin (1995: 272) argues that, "[perhaps] this entity was Islamic, but it was hardly a state, and it certainly did not rule Afghanistan". Within weeks, the agreement unraveled. The resulting war between the different factions led to a wide-ranging destruction of the capital between 1992 and 1994. Among the main combatants were Hezb-i Islami (led by Hekmatyar), Jamiat-i Islami (led by Massoud), and Junbesh-i Milli (led Dostum), networks that should dominate Afghan politics again after the fall of the Taliban (Rubin 1995: 272-274). By the mid-1990s, the state of Afghanistan had ceased to 
exist: There was no centrally controlled army, and the remnants of the state police were controlled by regional warlords (Giustozzi and Isaqzadeh 2013: 32-34).

While Afghanistan was mired in civil war, the rise of the Taliban movement began in 1994. Initially recruited among the millions of Pashtuns who lived at refugees across the border in Pakistan and funded by the Pakistani government, the Taliban quickly defeated almost all mujahedin factions between 1994 and 1996 (Rashid 2000: 26-27). According to Rashid (2000: 97), “[the] Taliban's emergence coincided with a fortunate historical juxtaposition, where the disintegration of the communist power structure was complete, the Mujaheddin leaders were discredited and the traditional tribal leadership had been eliminated". They conquered Kabul in 1996 and, by 2001 they were ruling large swaths of Afghanistan. Only Shura-i Nazar, the armed sub-group of Jamiat which was led by Ahmed Shah Massoud retained control of substantial parts of Northeastern Afghanistan (Schetter 2003: 516-551).

The Taliban system had its center of gravity in Kandahar, and was organized in the fashion of a one state party. They were mainly Pashtuns from the Durrani tribe (Rashid 2000: 9899). In terms of state formation, the Taliban achieved little during their reign from 1996 to 2001. The armed forces of the Taliban regime, numbering approximately 25,000 - 30,000 men, were theoretically structured like a modern army, with a chief of staff and an organization into several divisions. However, there was no clear chain of command. Mullah Omar was the head of the armed forces. Additionally, there was a Military Shura which would work on strategy and tactics. While the Military Shura, chief of staff and head of the armed forces existed as individual offices, Mullah Omar had monopolized most decision-making powers (Rashid 2000: 99-100). He also rotated military commanders at all levels in order to keep them under control and prevent them from developing patronage networks. However, these tactics led to a highly unprofessional military leadership. At the lower levels, most soldiers did not receive regular payments, but were directly supplied by their commanders. Thus, as Rashid has pointed out, the actual fighting force of the Taliban resembled a tribal militia rather than a modern military (Rashid 2000: 99-101).

Soldiers were recruited through a conscription system which put a heavy burden on the population, in particular on the Pashtun tribes who had to bear the brunt of recruiting. This led to all kinds of shirking and resistance on part of the village elders in the south, who had to give away their young men for the Taliban's war in the north (Malkasian 2013: 67-69). However, the 
regime also relied heavily on Pakistanis to fill the ranks of the army. There are estimates that in 1999, for example, about one third of the force consisted of young Afghan men that were recruited through madrassas in Pakistan (Rashid 2000: 100). Overall, the degree of institutionalization and the actual military strength were very low.

However, the Kandahar Shura (headed by Mullah Omar) did not only control all military matters. The Taliban erected the most centralized system of rule that had been created in Afghanistan to that date. The inner circle personally selected leaders at provincial and district levels. Through a system of personal appointment and rotation, the Taliban leadership tried to maximize control and minimize the ability of local elites to build their own power bases. The power of the tribal leaders was broken in many parts of the country, and they were replaced by Mullahs. Hence, Taliban rule drastically changed Afghanistan's power relations, producing clear winners (religious elites) and losers (tribal elites). Tribal leaders and village elders were further weakened by land reform. Local elites were often land owners, and their power depended on the economic advantage that comes with having more land than others in an agricultural society. Taxation was increased and a draft was introduced to keep up the war in the north against the last remnants of Shah Massouds forces (Malkasian 2013: 63-69).

Nevertheless, the Taliban never succeed in fully monopolizing the means of violence. While they gradually conquered parts of the North, they never completely defeated the welltrained forces of Shura-i Nazar (Jamiat) that had defended a small part of territory in the north eastern region. Furthermore, the Taliban build weak armed forces and weak governance structures. Jalaluddin Haqqani supported the Taliban militarily and was rewarded with the position of Minister of Borders and Tribal affairs, but he remained in control over his forces (Dressler 2010: 8-9).

Overall, in terms of state institutions the Taliban did not rebuild what the civil war had destroyed. They were not able to do so, but they were also not interested in building a modern state. Instead, their Islamic Emirate was solely built on the control over an army funded by Pakistan and personal loyalties to a charismatic leader. The army resembled more a militia than modern armed forces, and policing had been devolved either to the army or local institutions. Policing powers mostly emanated from the rule through local religious leaders, which allowed the Taliban to enforce a draft and generate some tax revenue. In the North, the state was unable to 
defeat Jamiat, even though the rebels lacked substantial external support. Hence, when the intervention began in 2001, the weak Taliban polity quickly fell apart.

\subsection{Statebuilding Intervention and Large-Scale Violence Regulation}

In its twelve year statebuilding intervention, ISAF and the Afghan government have failed to create a monopoly on large-scale violence. When the mission was officially ended in 2014 , the civil war between the Taliban, the Haqqani Network and the central government continued. This section argues that the cause of this monopolization failure was the competitive regional constellation in which Pakistan and India are caught in an enduring rivalry. However, before explicating the causal mechanism, I will provide an overview over the statebuilding mission and its components that deal with large-scale violence monopolization.

The statebuilding intervention in Afghanistan was perhaps the most resource-intensive statebuilding effort of all. While ISAF was initially conceptualized as a light footprint mission, it was gradually transformed into a statebuilding intervention (Lister and Wilder 2007: 242-243). At its peak in October 2010, about 149,000 ISAF troops were deployed across the country to fight the Taliban, train Afghan security forces and, thereby, create a monopoly on violence (ISAF 2011). The US alone spent over $\$ 700$ billion between 2001 and 2014 on the intervention in Afghanistan (cf. Cordesman 2012). Yet by 2014, the Afghan state did not have a monopoly on large-scale violence.

Initially, the Taliban were quickly defeated by an alliance of the United Front (i.e. Northern Alliance) and the US. With limited air support and American Special Forces, United Front fighters managed to quickly conquer most of the country (Giustozzi 2009: 88-90). Similar to the case in Sierra Leone, the international intervention in Afghanistan began with relatively modest means. Against the backdrop of the US war on terror, the international community agreed on a plan to transform post-Taliban Afghanistan into a liberal state. At the Bonn Conference in December 2001, international and Afghan actors agreed upon a schedule for the establishment of a transitional government, the drafting of a constitution and elections. In order to support the new Afghan government, the International Stability Assistance Force (ISAF) was set up. About 4,000 
soldiers were deployed to Kabul in the beginning of 2002 (Saikal 2006a: 527-529). Over the following years, the focus shifted modest assistance for the Afghan government to one of the most ambitious and expensive interventions ever conducted. In 2005, NATO ministers agreed to a plan to expand ISAF to the whole Afghan territory, to put ISAF and OEF under one command and to increase the military presence from 9,000 to 15,000 troops (NATO 2005). In January 2006, the international community agreed on the Afghanistan Compact which officially updated the intervention's goals. The compact clarified that the intervention aimed at establishing security, democratic governance, the rule of law, respect for human rights, and economic and social development (Afghanistan Compact 2006: 2). With regard to the monopoly on large-scale violence, the Afghan security forces were meant to be expanded significantly. By 2010, the ANA was supposed to have grown to 70,000 soldiers, while the ANP was set to reach a strength of 62,000 officers. Armed groups were supposed to be disarmed until the end of 2007 (Afghanistan Compact 2006: 6).

\section{The Regional Competition Mechanism}

The statebuilding project in Afghanistan was ambitious, protracted and very costly in terms of lives and money. Yet it ended with a failure to build a monopoly on large-scale violence. While the intervention has created an Afghan state that controls up to 260,000 soldiers and 160,000 police officers, the armed groups who oppose the regime were able to survive both the international military operations and the expansion of national security forces. This section explains how the regional constellation affected the statebuilding outcome by tracing the process with the help of the regional competition mechanism which I have developed in chapter three. 


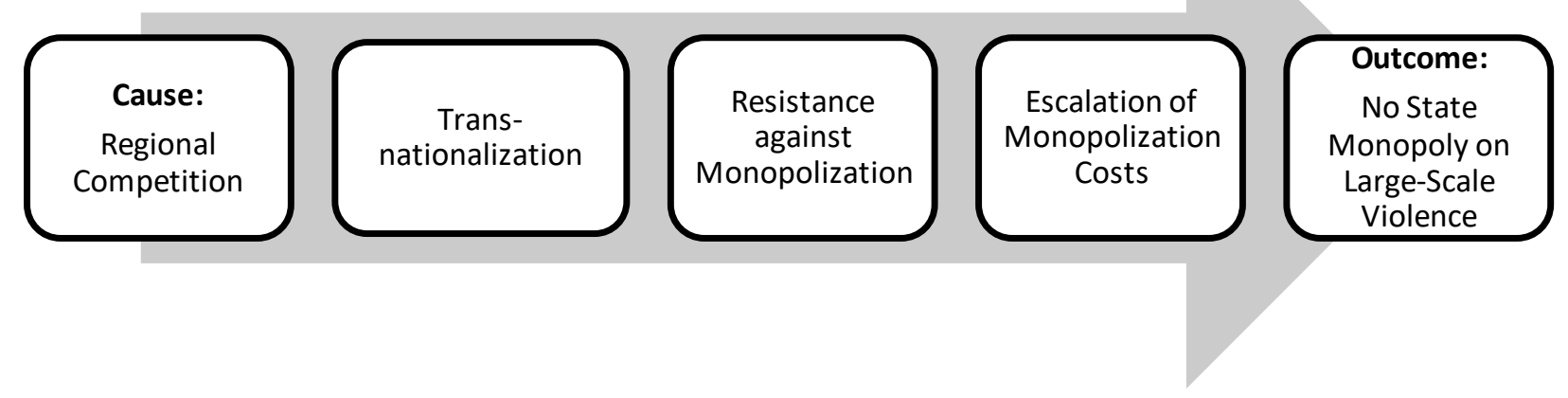

Figure 8: Regional competition mechanism.

This section argues that the cause of monopolization failure in Afghanistan was the competition of two key regional actors. The enduring rivalry between India and Pakistan structures the strategic thinking of Pakistani security elites. In order to ensure strategic depths and to avoid being encircled by India and India-friendly regimes, Pakistan thus supports anti-Indian actors in Afghanistan. Although Pakistan always cooperated with the US in certain areas like counterterrorism, it fundamentally opposed the Afghan state under Hamid Karzai. This constellation triggered the regional competition mechanism that translated regional conflict into an enduring civil war in Afghanistan:

(1) Transnationalization: Step one of the mechanism concerns the transnational dimension of the conflict. Pakistan provided the Afghan Taliban with access to its territory and to global markets. At times, it even supported the Taliban directly. Therefore, the monopolization process always took place in a transnationalized environment without effective or even accepted borders between Afghanistan and Pakistan. As a result of the transnationalization, the armed groups that opposed ISAF's monopolization process could use Pakistan as a safe haven. This allowed them to escape physical destruction, keep their basic organizational capacities and eventually rebuild their capacity to conduct large-scale violence.

(2) Resistance against Monopolization: ISAF starts to build a monopoly on large-scale violence by launching DDR and SSR programs. It invested into a new Afghan army and expanded territorial control. However, due to their sanctuaries in Pakistan, the Taliban 
were able to successfully block the monopolization effort and hold territory in Afghanistan.

(3) Escalation of Costs: Since the armed groups could retain their means of large-scale violence, NATO and the Afghan government expanded the Afghan security forces beyond sustainable size. The costs of intervention increased so that international actors eventually seek to exit the country without finishing the monopolization project.

The outcome is a failure of the ISAF mission to create a state monopoly on large-scale violence. The last year of the statebuilding intervention was also the year with the highest number of casualties among the Afghan security forces: In 2014 alone, over 4,600 ANSF personnel have been killed in the ongoing civil war (Reuters 2014a). This clearly indicates the strong means of large-scale violence controlled by the armed groups.

\section{Cause: Regional Competition in Afghanistan's Neighborhood}

This section argues that Afghanistan is caught in a competitive regional constellation. Of the cases discussed in this book, Afghanistan has by far the most complex neighborhood. The regional security complex is heavily influenced by the great power competition between India and Pakistan. While Iran strives to become a regional power itself, it has a stronger focus on the Middle East, where it sees itself as a patron of the Shia populations of several states. The former Soviet republics in the North of Afghanistan are more oriented towards Russia, although many Afghans are of Uzbek, Tajik and Turkmen ethnicity. Although Pakistan is the crucial actor with regard to the statebuilding intervention, it is necessary to briefly discuss the degree of regional integration and the stance of Afghanistan's other neighbors.

Afghanistan is located at the intersection between three world regions: The Middle East (Iran), Central Asia (the former Soviet Republics Turkmenistan, Uzbekistan, and Tajikistan) and South Asia (Pakistan) (see figure 9). As discussed in the history chapter, Afghan politics have been strongly shaped by its location as a land-locked country in between the spheres of influence of great powers. When compared to Africa, the region is more developed and has stronger states. Its main regional powers are Pakistan and Iran, while the Great Powers Russia and India mark the 
outer fringes of Afghanistan's neighborhood. The region is characterized by 'lower middle income countries' (India, Pakistan, Turmenistan, Uzbekistan), one 'upper middle income country' (Iran) and two poor countries (Afghanistan, Tajikistan) (WorldBank 2014). Thus, while most countries in the region are not rich, they are significantly more developed then most subSahara African states. This is also reflected in the strength of central governments. While most of the countries do fairly well in terms of their monopoly on violence, Afghanistan and Pakistan are the stark outliers (BTI 2012).

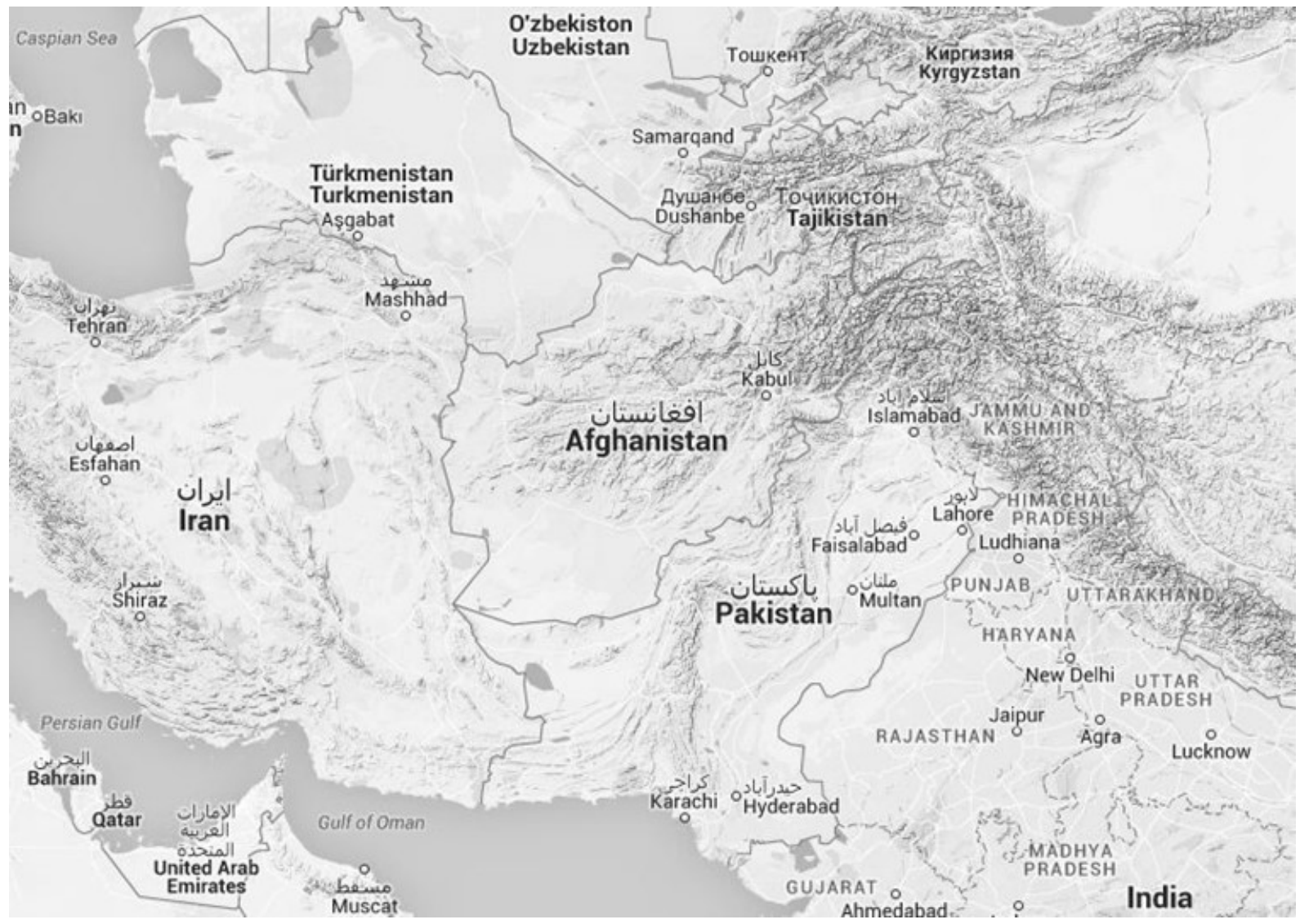

Figure 9: Map of Afghanistan and its neighbors $\{$ Google, $2014 \# 759\}$.

The degree of regional integration is minimal. Regional organizations in Asia are mostly platforms for enhanced coordination of state activities and emphasize a strong norm of sovereignty. Platforms such as the Shanghai Cooperation Organization or the Asian Cooperation Dialogue have a very narrow scope (often times focused on economic cooperation) and are rather 
exclusive (Webber 2010: e.g.). Even if there was more regional integration in Eurasia, Afghanistan would not be a clear member of any sub-region. For example, the post-Soviet states are stronger oriented towards Russia, while Pakistan is more strongly drawn into China's orbit. Overall, there is no regional institution that would have such a strong role as ECOWAS in West Africa or the European Union on the Balkans.

\section{Turkmenistan, Uzbekistan, and Tajikistan}

Until 1991, Afghanistan had only one neighbor in the north: The Soviet Union and, before that, the Russian Tsarist Empire. Since 1991, the former Soviet republics Turkmenistan, Uzbekistan, and Tajikistan share a border with Afghanistan. The three countries have inherited rather strong institutions and autocratic rule from the USSR, and their main interest in the past decades has been to insulate themselves from radical Islamism in Afghanistan. Uzbekistan is the most powerful of the three with a population more than two times as large as those of the other two combined. It is ruled autocratically and operates strong armed forces. Uzbekistan's key interest is the survival of its regime and a strengthening of state rule. The biggest threat to the regime so far was the ascent of Islamic Movement of Uzbekistan (IMU), which started a jihad against the government in 1998. The Uzbek government responded by attacking IMU bases in Tajikistan and Turkmenistan, demonstrating that it is willing to use force across borders to protect its interests (Stein 2012: 76-77). While Uzbekistan backed Junbesh during the civil war in the 1990s, since then it has confined itself to external interference only when directly threatened. Although there is a large Uzbek minority living in Northern Afghanistan, the Uzbek government has no policy to protect 'ethnic kin' abroad (Fumagalli 2007: 107-108). However, Uzbekistan's government sees the Afghan war as a regional conflict and has repeatedly called for a regional settlement, both during the Taliban rule and ISAF's intervention (Stein 2012: 78-79).

\section{Iran}

While Iran is a regional power with aspirations to become a Great Power (e.g. through acquiring nuclear weapons), it has stayed noticeably neutral regarding the intervention in its neighboring country. Iran's population of 77 million consists almost exclusively of Shiite Muslims. This 
contrasts with the Sunni dominated Arab world, especially states such as Saudi-Arabia, but also with Sunni Afghanistan. Iran's foreign policy is strongly shaped by two factors: The Arab world and the USA. Like Pakistan, Iran was subject to the state formation through inter-state war mechanism. In the 1980s, Iran was attacked by Iraq and drawn into a long and bloody war. At the same time, the country has had hostile relations with the US since the Islamic Revolution in 1979. The enduring rivalry with the world's foremost superpower was certainly a major incentive to strengthen its military capabilities as well as to develop nuclear weapons. However, Teheran was always careful to not risk an open conflict with the US. At the same time, it has used its ties to Shia groups (like Hezbollah) and Shia-dominated states (Syria, Iraq since 2003) to manage potential threats from its Arab neighbors (Barzegar 2009).

Historically, Persia was an important actor for the area that became Afghanistan in the modern era (Schetter 2003: 193-197). Hence, Dari (the Afghan version of Farsi) is one of the two official languages in Afghanistan. In modern times, Iran backed the mujahedin against the Soviet Union, and later supported the factions that fought against the Taliban. The Iranian government opposed the Taliban not only because they were radical Sunnis, but also because they were suspected to support anti-regime forces in Iran (Rashid 2000: 189-203). During the reign of the Taliban in the 1990s, tensions between the two states arose that almost led to an Iranian intervention (Rashid 2000: 203-204). Nevertheless, interaction between the modern states of Afghanistan and Iran has been much less intense than Afghan relations to Pakistan.

\section{Pakistan}

Pakistan is arguably the most important and powerful neighbor state of Afghanistan. With a population of over 180 million people, Pakistan is by far the largest state in the direct neighborhood (while at the same time it is dwarfed by its neighbor India's population of one billion). While it is not a rich country, Pakistan is not in the lowest income classification of the World Bank (over 1,000 GDP per capita) (WorldBank 2014).

Pakistan is a major military power. Perhaps its most distinguishing feature is its status as a nuclear power, which it acquired after testing atomic weapons at the end of the 1990s. Its army has a size of over 600,000 active soldiers (plus about 500,000 reserves). The history of Pakistan 
after independence in 1947 was strongly shaped by wars and conflict with India over the Kashmir region. In this sense, Pakistan had a classical state formation experience. Pakistan's security establishment views India as the outstanding threat to national security (Yusuf et al. 2011). Hence, the military strategy is above all shaped by the desire to deter India and to avoid being encircled by Indian allies. In order to achieve these goals, Pakistan has acquired nuclear weapons, sustains a large armed force and supports militants in the border region to India.

Despite these massive military capabilities, Pakistan has not a full monopoly on the use of force. Part of this is by design: The Federally-Administered Tribal Areas (FATA) and the NorthWestern Frontier Province (NWFP) are controlled by local tribes and governed by Islamabad through indirect rule. Many districts have seen little government presence since Pakistani independence in 1947. During the last decade, the Pakistani government had to fight several inconclusive counterinsurgency campaigns against tribal uprisings in the north-western border region to Afghanistan. There is a long-standing dispute between Afghanistan and Pakistan over the Durand-Line, which the Afghan government does not officially accept as the border between the two states. Both states have historically seen themselves as protectors of the Pashtun tribes. However, the tribes have mostly tried to avoid becoming part of either state (Schetter 2003: 263267). Thus, an important step of state formation, the acceptance of borders, has not been taken by the two states.

With regard to Afghanistan, Pakistan's strategic goal has been to avoid encirclement by pro-Indian forces (Yusuf et al. 2011: 38-39). Thus, during the Soviet-Afghan War Pakistan (and the US) massively supported the anti-communist Mujahedin. After the Soviet withdrawal, it has supported the Taliban as a Pashtun force against the warlords of northern and western Afghanistan. While it is not completely clear whether the civilian government or the military leadership dominates Pakistan's security policy-making, the wider foreign policy elite shares certain views regarding the NATO intervention Afghanistan since 2001. A study based on interviews with military officers, politicians and journalists from the Pakistani security establishment has concluded that Pakistan's strategic goals in the conflict are to create a stable Afghan government that includes the Quetta Shura Taliban and possibly the Haqqani network, and which denies India a larger role in development assistance (Yusuf et al. 2011: 12-13). Whether or not this logic is sound, it is true that the Karzai administration has closely cooperated with India. India has been one of the major donors from the beginning. It has supported the new 
Afghan state through a range of development assistance and aid, but has always strayed away from supporting the military aspects of intervention. This has been described as an effective soft power approach by India which has a strong interest in preventing a return to a Taliban regime. In October 2011, the two states signed a strategic alliance agreement (D'Souza 2011).

To sum up, Pakistan is the most important neighboring country for Afghanistan. The region lacks strong institutions that could mitigate conflicts and secure cooperation between all relevant actors. Since the Pakistani security establishment views India as a threat to national security, it has a strong interest in strengthening anti-Indian actors in Afghanistan. The next section shows how this policy preference translated into a transnationalization of the conflict.

\section{Step one: Transnationalization}

The competitive regional constellation caused Pakistan to see the statebuilding intervention in Afghanistan as a threat. As a result, Pakistan allowed the armed groups that opposed the statebuilding intervention in Afghanistan to freely operate across the Pakistani border. The result was that the Afghan rebels had sanctuaries for their leadership, access to global markets to sell drugs and buy arms, and greater populations in which they could recruit their troops.

Pakistan has fought wars against two enemies which continue to be seen as the main threats to national security: India and the Tehrik-e Taliban Pakistan (TTP). While India has been seen as an enemy since independence, TTP is a fairly new threat. However, Pashtun insurgent groups that operate in Afghanistan are not perceived as a threat but as an important tool to retain influence in the neighbor country (Waldman 2010: 4-5). These strategic priorities shape Pakistan's seemingly contradictory strategy with regard to the statebuilding intervention in Afghanistan. Officially, Pakistan supports NATO in Afghanistan and has been one of the signatories of the Afghanistan Compact (2006). However, the relationship between Pakistan and the US is much more complex than simple formulas such as 'allies in the war on terrorism' suggest. After 9/11, Pakistan has fulfilled some of the demands the US had. Pakistani authorities helped to capture or kill a significant number of al-Qaida leaders. One of the most important aspects of cooperation was that the CIA was allowed to use Pakistani air fields to run its drone operations against Islamist militants within Pakistan. In return, the US has supported Pakistan, 
and especially the Pakistani armed forces, with billions of dollars in aid and military equipment (ICG 2013: 1-5). Despite seemingly cooperating, Pakistan has maintained its long-term strategic priorities. Islamabad has supported Pashtun groups who fought against the Afghan state in order to weaken the India-friendly Karzai government (Farrell and Giustozzi 2013; Hänni and Hegi 2013; Waldman 2010). The scale of operations by Afghan armed groups within Pakistan and the ease with which they can cross the border cannot be explained by a weakness of the Pakistani state. Whereas the Federally Administered Tribal areas are ruled indirectly, both Belochistan (from where the Quetta Shura operates) and the former Northwestern Frontier Province (now: Khyber Pakhtunkhwa) are ruled directly by the Pakistani state (Fishman 2013: 340-341). Furthermore, it has restricted the areas in which the US could conduct drone strikes. While drones have attacked a vast number of targets in tribal areas of the Northwest, there have been no attacks in Belochistan where the Quetta Shura is located. The US is allowed to attack TTP and alQaeda targets, both of which are threatening the Pakistani state, but there have been very few instances of drone attacks against Pakistan-based armed groups that operate in Afghanistan ${ }^{21}$ (ICG 2013: 22).

Overall, Pakistani policies had a strong impact on the capability of armed groups to challenge the Afghan government's claim to a monopoly on violence. In order to illustrate the importance of Pakistan's transnationalization strategy, it is necessary to analyze how Afghan insurgency groups re-organized after their initial defeat. However, the insurgency is less homogenous than the term 'Taliban' suggests. It consists of seven armed groups that all fight against the government and its external backers:

Organisationally, the insurgency is segmented and consists of seven armed structures: the Islamic Movement of the Taleban, the networks of the Haqqani and Mansur families in the South-East, the Tora Bora Jehad Front (De Tora Bora Jehadi Mahaz) led by Anwar-

\footnotetext{
${ }^{21}$ At first sight, this should appear to be reason enough for the US to cancel all support for Pakistan and treat it as a Pariah state. However, most likely the US government fears that the radical Islamists of Pakistani Tehrik-e Taliban (TTP), the strongest anti-government force in Pakistan, could overthrow the government and, thereby, establish control over the country's nuclear arms.
} 
ul-Haq Mujahed in Nangrahar (Eastern region), HIG, small Salafi groups in Kunar and Nuristan provinces (Eastern region)28 and, as a new phenomenon, a number of not interrelated local exmujahedin groups that (or whose historical leaders) had been pushed out of power, are taking up arms and starting to adopt Taleban-like language and behaviour. (Ruttig 2009: 10)

However, only two groups are able to effectively challenge the state's claim to a monopoly on violence: The Quetta Shura (QST, or Afghan Taliban) and the Haqqani Network (HQN) (Waldman 2010: 2). These two groups work together under the 'Taliban' umbrella, and formally HQN accepts the Taliban's leadership. While the Afghan Taliban are the biggest group and operate mainly in the South, Haqqani operate in the Eastern parts of Afghanistan. Hence, it is useful to focus on the two major armed groups in the Afghan civil war.

\section{Organizing Armed Resistance - The Haqqani Network}

Jalaluddin Haqqani was a tribal leader from Loya Paktia who started fighting against the Daud government during the 1970s. Already during this time, Pakistan funded Islamist resistance groups in order to prevent Afghanistan from becoming a nationalist or communist state. Since then, the Haqqani network has enjoyed the support of Pakistan. In 1995, Haqqani joined the Taliban movement while retaining control over his military capabilities. He became minister in the Taliban's cabinet, but was excluded from the decision-making process because he was neither a Kandahari nor a Durrani Pashtun. After the US invasion, the Haqqani clan first retreated to Miram Shah in North Waziristan, Pakistan, where they re-established contact to the Taliban in 2003. Since then, Jalaluddin has been succeeded by his son Siraj who has transformed the Haqqani Network into the most professional Afghan insurgent force, and the strongest opponent of the new government in Eastern Afghanistan. While the network remained an autonomous entity, strategic leadership was apparently exercised by the Quetta Shura (Dressler 2010: 7-11).

The Haqqani Network has used North Waziristan as its organizational center. "The Haqqani network maintains its main command and control, training, and logistical node in and around Miram Shah, the largest town in Pakistan's [North Waziristan]. [..] From Miram Shah, the Haqqanis run a parallel administration that includes courts, recruiting centers, tax offices, and 
security forces" (Dressler 2010: 11). From there, it had access to the Loya Paktia region which entails the provinces Khost, Paktia and Paktika in Eastern Afghanistan. Even before the Quetta Shura began its armed resistance in the South in 2003, there were attacks against the new Afghan government in the region between Zabol and Nuristan, indicating that HQN was faster in reorganizing itself than the QST (Maloney 2008: 203). In late 2003, the Haqqanis had established control of half of the mountainous province of Paktika and began to operate in large units of several hundred militants. (Dressler 2010: 21) Thus, due to their access to Pakistani territory, HQN was able to organize a major armed force within less than two years. It took the QST only little longer to recover from their ousting from power in 2001 and return with a vengeance.

\section{Organizing Armed Resistance - The Quetta Shura}

The intervention in 2001 defeated the Taliban in most areas of the country. Even in the South, the Taliban feared a total defeat at the hands of the Northern Alliance and the US and, thus, withdrew to Pakistan (Farrell and Giustozzi 2013: 847-848). Too weak to resist, the organization could have collapsed in the early months of the intervention. However, the leadership managed to escape to Pakistan, from where it could rebuild its organization and reinsert its fighters into southern Afghanistan. The main target areas of this rebuilding phase were Helmand and Kandahar. Kandahar City is the former capital of the Taliban movement, and it is of great strategic importance to anyone who wants to rule Afghanistan. Home to a population of 500,000, it is the second biggest city of the country, located at Highway 1 ('ring road'), and a logistical hub for trade across the Afghan-Pakistani border. After the Taliban's retreat in 2002, neither the government nor the international community had the capacities to control Kandahar province. Instead, a US battalion was stationed at Kandahar Air Field, while an AMF unit was sent into Kandahar City. The rest of the province had to govern itself without support from either the government or the intervention force (Maloney 2008: 203-204).

In 2003, the Taliban started a propaganda campaign in which they communicated (via fax and email) that they still exist, and that Mullah Omar continues to lead the organization. This message was underlined by a very limited guerilla war against the forces in Kandahar (Maloney 2008: 204). "The establishment of Taliban base and support structures in Pakistan of course predates the 2001 intervention but these structures were reactivated in late 2002. By 2003, the 
Taliban was able to mount the first cross-border foray into southern Kandahar Province west of Spinboldak" (Maloney 2008: 204). By 2004, the Taliban set up insurgent cells in several rural districts surrounding Kandahar. Taliban Mullahs were sent to districts to influence local Mullahs, and night letters were delivered to threaten anyone who might be willing to work with the government. In 2005, the Taliban had become so strong that they switched to a war of attrition strategy. The Taliban controlled several districts around Kandahar, started to interrupt traffic flow into the city on the strategic Highway 1, infiltrated the police force and staged high-profile suicide attacks in the city center (Maloney 2008: 206-209). By 2006, Taliban forces had erected conventional defense systems in the districts surrounding the city. They governed much of the province and aimed at controlling the streets that are the lifelines of Kandahar City (Maloney 2008: 212).

The same pattern can be found in Afghanistan's Helmand province, although the capital Lashkar Gar has neither the size (200,000 inhabitants) nor the strategic importance of Kandahar City. Outside the provincial capital and some district capitals, the government had no capacities to govern in the aftermath of the regime change. Thus, it relied instead on warlords and tribal leaders in order to somehow extend its influence into the province.

In 2004 and 2005, the Taliban first send Mullahs to spread propaganda, followed by small teams to assess the situation and to organize political support. These small groups also staged hitand-run attacks against the few pro-government forces (Farrell and Giustozzi 2013: 849 ; Malkasian 2013: 86). As with the central government, there were parts of the population who were against the Taliban, while others supported them. Groups which have traditionally suffered from the tribes (mostly landless 'immigrants'), and those who have benefited from the Taliban regime during the 1990s (the religious elites), embraced the return of the Taliban (Malkasian 2013: 149-155). By 2006, the Taliban operated in groups of hundreds of fighters and openly conquered districts in which only the district center was held by the central government (Farrell and Giustozzi 2013: 849-850).

To sum up, Pakistan allowed Afghan armed groups to use its territory as a sanctuary. This transnational space was decisive for re-organization, both in the cases of the Taliban's strategic center in Quetta and of the Haqqani Network's retreat in North Waziristan. Consequently, their 
defeat at the hands of international and Afghan forces in 2001/2002, and their subsequent disappearance from most of Afghanistan, had no lasting effect.

\section{Step Two: Resistance against monopolization}

The occupation of transnational spaces enabled the Taliban and their allies to resist the monopolization efforts of ISAF and the Afghan government. Whereas the statebuilders expanded the organizational capacities of the government, they were challenged by the Taliban in those areas that bordered on Pakistan.

The Afghan National Army was meant to become a lean and sustainable force that guaranteed that Afghanistan would not again become a harbor for armed groups and international terrorists. At the beginning of the intervention, a true national armed force did not exist anymore in Afghanistan. Instead, warlords commanded a few hundred troops each, while Shura-I Nezar still commanded up to 15,000 troops. The US support for the Northern Alliance warlords since 2001 allowed them to massively expand their armed forces. Within months, the warlord factions could mobilize thousands of fighters who overran the Taliban with the help of US air support (Giustozzi 2009: 87-89). Since the warlords were the only actors allied to the West who controlled means of large-scale violence, these groups were chosen to be the core of the new Afghan security forces. It was envisaged to integrate them into one army and to turn them into a professional force. The different militia groupings were organized into the Afghan Military Force (AMF), which filled out the role of the official military until the creation of the ANA in 2003 (ICG 2010a: 7). "The AMF, which represented the bulk of Afghan security forces, consisted largely of militias that had filled the security vacuum in 2001. Although the number of active militia personnel shrunk from 75,000 in 2002 to 45,000 by the end of 2003, the number of AMF divisions expanded to 40 during roughly the same period" (ICG 2010a: 7). This early incorporation of well-organized militias into the official armed forces laid the foundation for the dominance of Tajiks in the higher command levels of the ANA. At the end of 2002, the Afghan National Army was officially created. The aim was to build an armed force consisting of 70,000 soldiers across all service branches, controlled by a national Ministry of Defense (Younossi et al. 2009: 12-13). However, the recruitment goals that had been initially declared were not met in the first years. The funding for recruitment was increased in 2004, so that the ANA expanded 
somewhat faster. Nevertheless, the modest expansion of commissioned battalions translated into a much slower growth of combat-ready units (Giustozzi 2007: 48-51). As a result, when the government was meant to expand its control over the whole territory in 2005, the ANA had only about 26,000 soldiers at its disposal (NYTimes 2005).

In late 2005, ISAF was expanded to the whole territory of Afghanistan (NATO 2005). With increased troop levels and more resources, the goal was to establish governmental control over the whole country. In order to achieve this, NATO troops (in particular British, Canadian and Dutch) were deployed to Helmand and Kandahar (Malkasian 2013: 91-92). There are several reasons for this focus: These provinces are not only home to about ten percent of the Afghan population, but also to large swaths of arable land (Helmand River Valley), and to the second biggest city of the country (Kandahar City). Furthermore, they border at Pakistan and have historically been important transit areas for trade and cross-border migration. Last but not least, they are the homeland of Afghanistan's biggest ethnic group, the Pashtuns. Any government that wants to exercise authority over Afghanistan has to be in control of these areas. The Afghan government had already started to deploy ANA to Paktika and Kandahar in 2004, facing stiff resistance from the Taliban. Through a combination of soldiers killed in action and wide-spread desertion, these units suffered attrition rates well over 50\% (Giustozzi 2007: 54). When NATO troops arrived in South Afghanistan, they faced armed groups that were not only well organized but had developed proto-state structures across Southern Afghanistan. They had re-erected their own systems of jurisdiction and taxation, and were able to build an army to control the region. Thus, ISAF's efforts to take control of key cities, roads and populations were countered by the Taliban by conventional means. They fought a territorial war, attacking ISAF outposts with battalion-sized combat groups (Malkasian 2013). For several years, southern Afghanistan experienced a symmetric war in which two actors of large-scale violence were caught in a bloody stalemate. Despite the ongoing monopolization efforts of ISAF and the Afghan government, the Taliban had re-built a strong capacity to control and apply means of collective violence. They militarily occupied large parts of Southern and Eastern Afghanistan, where they installed their own system of governance, taxation and recruitment. The political leadership remained in Pakistan, where “[..] since 2007 the Taliban's military structure has been centred on two military commissions [..]: one in Quetta and the other in Peshawar" (Farrell and Giustozzi 2013: 855). 
Overall, the Taliban had recovered by 2003 and were able to resist the military expansion of both ISAF and the Afghan government.

\section{Step Three: Escalation of monopolization costs}

In the final step of the causal mechanism, the resilience of armed groups led to an escalation of the monopolization effort. The statebuilders expanded the Afghan security forces beyond the limits of sustainability. However, the continued access to transnational spaces allowed the Taliban to endure the monopolization offensive until the costs for the interveners were high enough to force them to withdraw.

In late 2005, as NATO realized that the Afghan government would not be able to establish a monopoly on violence if the Afghan National Army did not accelerate recruitment. While the Afghanistan Compact (2006) reaffirmed initial target (70,000 ANA, 60,000 ANP), it clearly articulated that this troop level should be met by 2010 (Afghanistan Compact 2006). However, subsequently the goals were further increased and by 2009, the target was an expansion to 260,000 ANA soldiers and 160,000 ANP officers in 2015. These were supposed to be support by a 45,000-strong militia operating under the label Afghan Local Police (ALP) (Goodhand and Hakimi 2014: 15). Thus, while the original plan so a force of 130,000 as an appropriate force for a country with about 35 million inhabitants, the statebuilders eventually deemed it necessary to triple that number. 


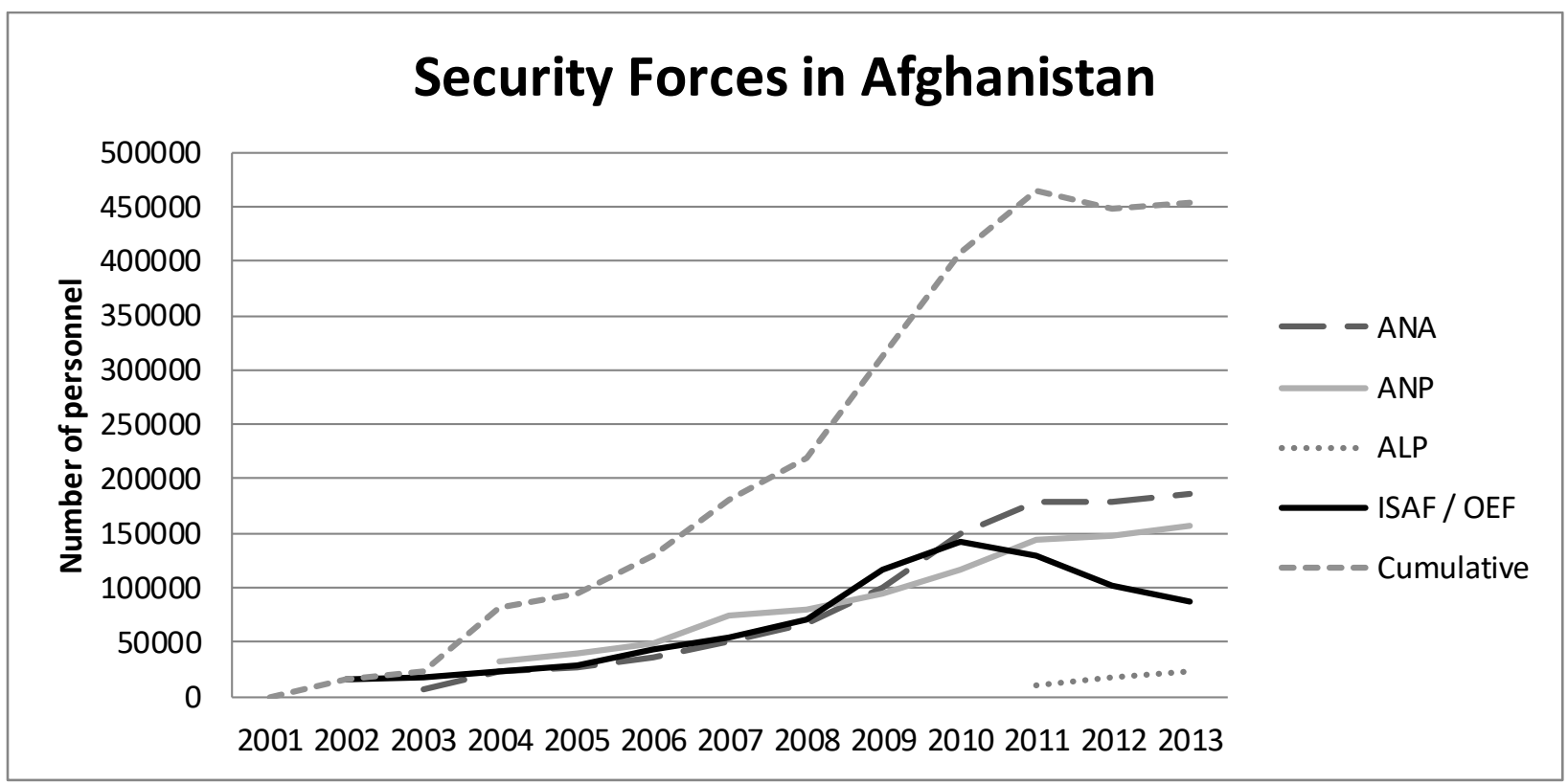

Figure 10: Number of Afghan National Security Forces, Afghan Local Police and ISAF troops.

The expansion of the Afghan Army was accelerated to an extreme pace. Within five years (20062011) the size of the ANA grew from 36,000 to 179,000 soldiers (see figure 10). In order, to achieve the expansion, recruitment requirements needed to be lowered while expenses shot up. While low rank soldiers are easy to recruit, the ANA lacks the officer corps to command these troops because the training of high rank soldiers takes much more time (DoD 2012: 46). Also, the ANA was still heavily dependent on external help for its operations. A report by the U.S. Department of Defense (DoD) assessed the state of ANA's capabilities in 2012. While the army conducted about $80 \%$ of all operations on its own, a great deal of operations was still planned by ISAF (DoD 2012). Even more problematic is the issue of financial sustainability as it is unclear how Afghanistan is supposed to finance its massive security apparatus. According to World Bank data, the annual Afghan security spending (FY 2012-2013) amounts to 10.7\% of GDP. This compares to domestic revenues of only $10.6 \%$ of GDP, while the donor money that goes directly into the state's budget is more than twice as high (WorldBank 2013a). This means the Afghan state is completely dependent on external funding, and is not even close to being able to pay for its security forces (see figure 11). 


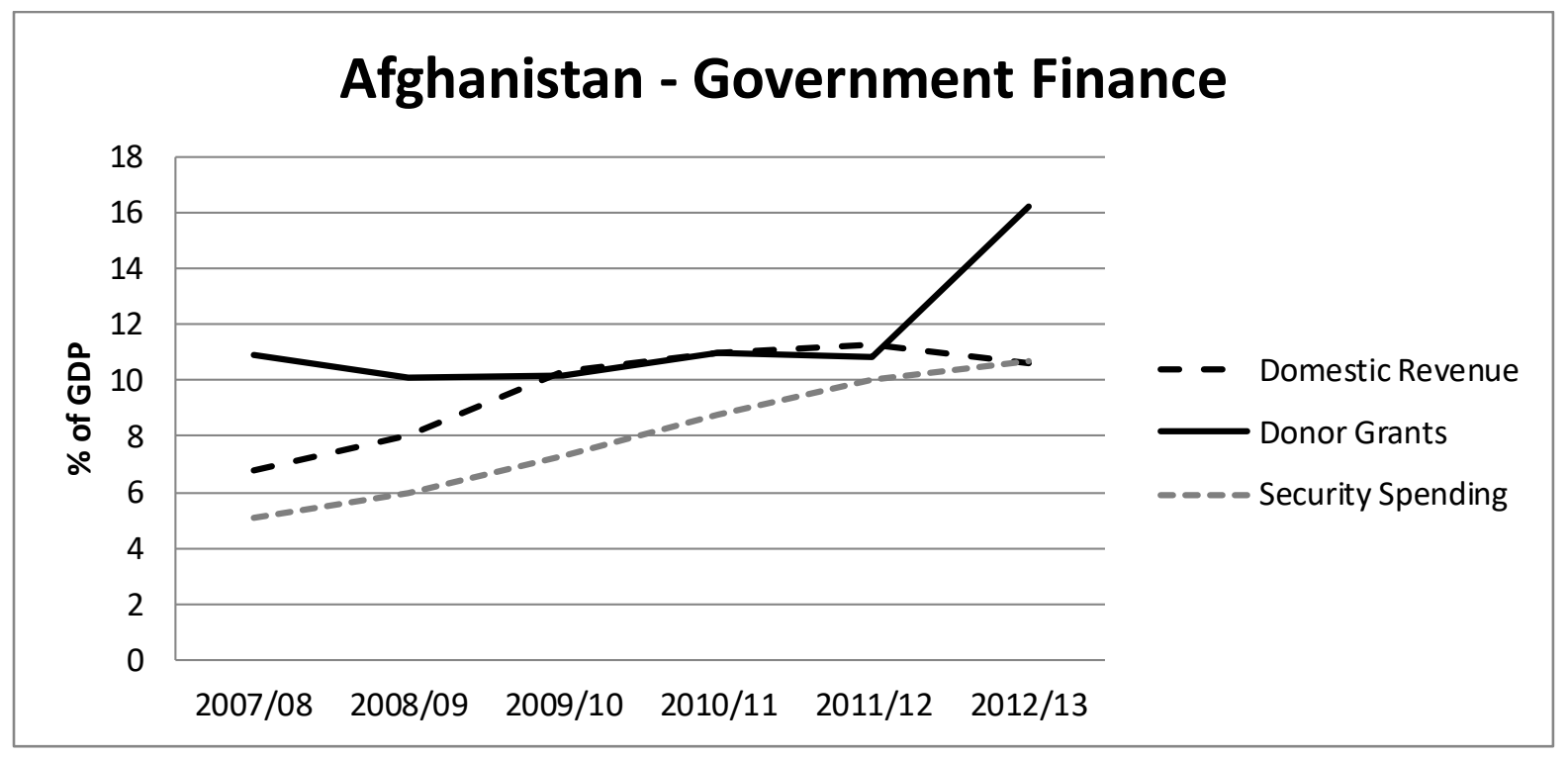

Figure 11: Afghan government finances (WorldBank 2014).

In 2009, the US government decided to shift resources from Iraq to Afghanistan. Large amounts of US troops were deployed to Helmand, the homeland of the Taliban insurgency, and troops in Kandahar were reinforced. US Special Forces began to massively increase raids to capture or kill mid-level Taliban leaders. ISAF troops increasingly conducted joint patrols with Afghan soldiers. Additionally to hiring more ANA and ANP personnel, an attempt was made to create a national militia system along the lines of the Iraqi 'Awakening Councils' (or the Sierra Leonean CDFs). At the same time, civilian assistance to the Afghan government was dramatically increased in order to guarantee that for every district the US conquered from the Taliban, there would be enough Afghan government capacities to fill in the gap (Farrell and Giustozzi 2013: 868-869). Overall, the balance in the market of large-scale violence tipped strongly in favor of the Afghan government.

Initially, the drastically increased pressure on the Taliban in Southern Afghanistan had a strong impact on their organizational capacities. Personal networks that developed between Taliban leaders on the middle and lower levels, and the links between Quetta and the middle-tier leadership, were partially disrupted by the targeted killing campaign (Farrell and Giustozzi 2013: 870). US forces pushed Taliban out of the Helmand River valley region and Kandahar city, and 
thereby deprived them of access to large recruitment areas. One local Taliban commander from Garmser reports:

Before, Garmser was a bridge for traffickers and we got lots of money from the traffickers as zakat [tax]. At that time we didn't need our leaders to support us; we could find the money for everything, weapons, ammunition, food and other necessary stuff. But now it's completely different; we have few villages under our control and collecting zakat from those villages is not enough. Most of our supplies are coming from Pakistan ... Only we can get our food here. (quoted in Farrell and Giustozzi 2013: 869)

Between 2006 and 2010, the situation in Southern Afghanistan, and particularly in Helmand, changed from one in which the Taliban could govern large areas to one in which they were reduced to a regular guerilla force. However, the success of these hugely expensive efforts was limited. First, the offensive focused on southern Afghanistan. Thus, it hit mostly the Qutta Shura, but to a lesser extent the Haqqani network in the East where the pro-government forces were strengthened but were insufficient to control much of the population (Dressler 2010: 37-38). Second, the Taliban could simply evade the pressure, switch to guerilla tactics and wait for the announced withdrawal of ISAF.

Despite the immense military pressure that both the expansion of ANSF to over 300,000 soldiers and police officers, and despite the surge of ISAF, the Taliban kept up their campaign in the years up to 2014. Fighting reached a new peak; while the number of ISAF troops killed in action was in decline due to the ongoing withdrawal, the number of ANSF casualties steadily increased. Of the over 13,000 soldiers and policemen killed in the conflict, over 8,000 were killed between March 2011 and March 2014 (NYTimes 2014b). While there are no reliable figures about the number of casualties for non-state armed actors, the UN estimates that 12,000 Taliban were killed in 2013 alone (Guardian 2013). In addition, civilian casualties peaked at 3,000 in 2013, and over 14,000 civilians have been killed between 2001 and 2014 (UNAMA 2014). There are no official estimates about the strength of the Taliban insurgency, but media reports indicate that NATO assumes that the number of Taliban is high and rising. Whereas the reported estimates were up to 20,000 in 2007 (WashingtonPost 2008), the strength seems to have grown to 35,000 in 2012 (Telegraph 2012). While being vastly outnumbered by ANSF, an armed group (or collaboration of groups) of such size would be a serious threat to any government's rule. 
However, without the safe havens in Pakistan, the logistics of the Taliban insurgency were impossible to protect against ISAF and the government. Paying, feeding, arming, and providing health care for 35,000 fighters demands an infrastructure that could hardly exist in a country in which NATO has deployed up to 150,000 troops. This indicates two things: First, despite massive statebuilding efforts, Afghanistan faces an escalating civil war in which the means of large-scale violence are owned by at least two major factions (government and Quetta Shura). Second, the scale of the Taliban insurgency would be unthinkable without substantial state support.

The effect of the Taliban's capability to resist monopolization and the ever rising cost of the statebuilding project was that the US sought to end the mission independently of whether it would succeed or fail. Presenting the new Afghanistan strategy in 2009, US President Barack Obama announced not only the 'troop surge', but added that "[a]fter 18 months, our troops will begin to come home"(WhiteHouse 2009). By spring 2012, NATO had developed an exit strategy, announcing that "[...] ISAF's mission will be concluded by the end of 2014" (NATO 2012). Subsequently, despite the ongoing civil war responsibility for security was officially transferred from ISAF to the Afghan government in June 2013 (NATO 2013b).

Overall, the Taliban have suffered heavy losses. Nevertheless, their access to transnational spaces secured them the organizational capacity to continue their fight against the central government. With headquarters in Pakistan, the armed groups were capable of coordinating and resupplying their resistance against monopolization.

\section{Outcome: No Monopoly on Large-Scale Violence}

The statebuilding intervention in Afghanistan has failed to establish a state monopoly on largescale violence. Although NATO will leave a supporting military force in the country to assist the government, the major statebuilding effort has ended with the official exit of ISAF. The withdrawal of ISAF occurred against the backdrop of ongoing large-scale violence in Afghanistan's east and south. Due to sustained access to transnational spaces, the Taliban were able to outlast some of the biggest military offensives in Afghan history and managed to continuously challenge the strongest Afghan army the state has ever had at its disposal. 
ISAF has achieved several goals that were necessary for a monopoly on large-scale violence. The warlords of the Northern alliance were largely disarmed and their forces were integrated into the official Afghan National Army. The ANA is widely seen as one of the most competent state institutions, and it can be argued that no Afghan government before had an armed force of this size and quality. It is still possible that Afghanistan will monopolize the means of large-scale violence on its own. However, as the events in Iraq after the US withdrawal in the early 2010s show, it is also possible that the Afghan state disintegrates further.

\subsection{Statebuilding Intervention and Small-Scale Violence Regulation}

As the previous chapter shows, ISAF and the Afghan government have failed to establish a monopoly on large-scale violence. Nevertheless, the statebuilders went at great lengths to consolidate those zones in which the government had broadly established control. In order to build a strong liberal state, the statebuilding intervention aimed at the monopolization of smallscale violence in the hands of the state. As in the case of large-scale violence, ISAF failed to replace non-state actors with state institutions of small-scale violence regulation.

In terms of institution-building, the international community and the Afghan elites had brokered a constitution that establishes an Islamic Republic of Afghanistan. While invoking its Islamic foundations, the constitution is "[..] based on rule of law [..]" (IRoA 2004: preamble) and defines many liberal goals such as "[..] preservation of human dignity, protection of human rights, realization of democracy [..]" (IRoA 2004: §6). With regard to small-scale violence regulation, the constitution states: "Discovery of crimes shall be the duty of police, and investigation and filing the case against the accused in the court shall be the responsibility of the Attorney's Office, in accordance with the provisions of the law" (IRoA 2004: §134). ISAF itself resorted to a standard Security Sector Reform approach that was meant to support the Afghan government in creating an accountable and effective police force as well as a judiciary that operated according to the principles of the rule of law (Afghanistan Compact 2006: 2 ; UN 2001a). Small-scale violence regulation in the new Afghan state was thus meant to be monopolized by the state. 
In theory, Afghanistan was supposed to have one system of rules (based on the constitution) that is enforced by the Afghan National Police. Districts and provinces would each have a governor, a Chief of Police (CoP) and a head of intelligence (NDS) (Murtazashvili 2014: 3-4 ; Saltmarshe and Mehdi 2011: 17-18). However, directly after the fall of the Taliban there was no proper police force and most communities continued to police themselves. In terms of policebuilding, ISAF at first aimed mainly at providing specialized expertise for the re-building of Afghanistan's police force. The lead nation, Germany, helped setting up the Police Academy in Kabul again and provided training for the future leadership of the new police. From 2005, the resources made available for police-building were drastically increased, and a stronger emphasis was put on increasing the number of low rank police officers. It is difficult to come up with precise figures of police advisors as police training after 2005 was conducting not only by civilian police officers (as was the case in the German police training program), but also by the private contractor DynCorp as well as by the US military (Friesendorf 2011: 84-88). Overall, policebuilding in Afghanistan went from an approach where the focus was on training a professional leadership to a stronger emphasis on quantity and paramilitarization.

\section{Weak State Legacy Mechanism}

This section argues that the cause of ISAF's failure to monopolize small-scale violence regulation was Afghanistan's history of weak statehood. It applies the weak state legacy mechanism to the case of Afghanistan, showing how the lack of a strong state prior to intervention has led to an outcome in which the state competes with non-state institutions for control over regulating smallscale violence. The analysis shows that despite creating liberal formal institutions and endowing the state with a strong police force of over 160,000 police officers, small-scale violence is still controlled by self-help communities. Before providing a detailed analysis, it is necessary to provide an overview over the causal mechanism. 


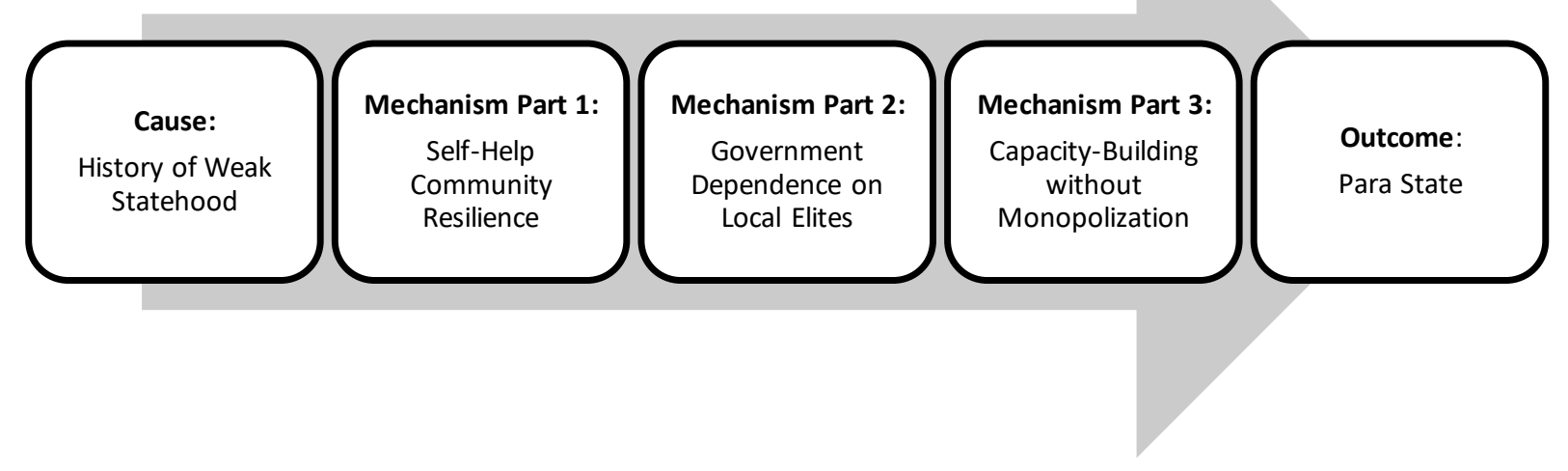

Figure 12: Weak state legacies mechani sm.

The cause of ISAF's failure to monopolize small-scale violence regulation in the hands of the state is the legacy of Afghanistan's history of weak statehood. Prior to the intervention, there has never been a strong central state. The strongest central governments that ruled over Afghanistan did so in an indirect manner, and a bureaucratized rule over local community had never been established when Afghanistan slipped into its three decades of civil war and outside intervention.

(1) Self-Help Community Resilience: When the series of crises that shattered Afghanistan began in the late 1970s, self-help communities were the dominant regulators of small-scale violence. Self-help communities showed resilience in the face of the collapse of the state as well as during Taliban rule. They were thus the mode of small-scale violence regulation when NATO intervention began in 2001/2002: Customary and religious law regulated life for the vast majority of the population at the local level, and these institutions were controlled by elites such as maliks, tribal leaders or mujahedin commanders. The state police had all but dissolved.

(2) Government Dependence on Local Elites: In the first months and years of the statebuilding intervention, there was no more state police that could have been used to rule Afghanistan. In contrast, self-help communities were strong, either in the form of 
tribes in the South or of the commander polities in the North. Thus, the Karzai administration needed to incorporate local elites in order to create a minimum amount of stability and taxation capacities.

(3) Capacity-Building without Monopolization: After a slow start, ISAF's efforts to provide the Afghan government with assistance for police-building and the expansion of state judiciary lead to a great increase in state capacities. However, local elites exercise strong influence over the government through informal networks, capture local police or public offices, and are thereby able to resist monopolization.

The outcome is a form of para statehood in which small-scale violence regulation remains in the hands of local non-state institutions although the state has amassed a large law enforcement apparatus. The following section will present a step-wise analysis of the causal mechanism, beginning with the initial cause: Afghanistan's history of weak statehood.

\section{Cause: History of Weak Statehood}

Although Afghanistan has been a state for about two centuries, it has never succeeded to monopolize the regulation of small-scale violence. The following section shows how successive governments launched attempts to weaken local elites and build policing capacities, but had eventually to acquiesce into the existing of self-help communities. With the advent of the civil wars era in the late 1970s, state policing eventually collapsed.

At the level of small-scale violence, the rulers of the emerging Afghan state were eager to adopt Western policing methods in order to control the population. As in Europe, specialized policing developed in Afghan cities during the $19^{\text {th }}$ century (Giustozzi and Isaqzadeh 2013: 13). First steps were already taken from the 1880s onwards, but only in the 1930s did the government institutionalize a modern police force. A Ministry of Interior was established in the 1920s and was granted control over police forces in the 1930s. In 1935, the government established the first police training center in Kabul, where police officers were trained according to manuals imported from Turkey (Giustozzi and Isaqzadeh 2013: 14). It was the first time that university graduates 
were recruited in order to increase professionalism. Early on, the Afghan government secured external help in order to professionalize its police forces. Thus, it established cooperation with Germany which continued after World War II. Turkey was another partner in building the Afghan police. During the 1950s and 1960s, the police acquired increasingly modern methods of criminal investigation. Overall, the government attempted to bureaucratize policing, make the organization more meritocratic and enforce internal discipline (Giustozzi and Isaqzadeh 2013: 21-24).

However, until the end of the monarchy, the police was led by military generals and, thus, did not develop into a fully autonomous policing organization. It was neither present in the whole territory, nor were rules applied consistently to all citizens. Policing spread uneven from the centers of power outwards, form Kabul to the main cities such as Kandahar and Herat, and only in the 1970s was policing institutionalized at the district levels across the country. Furthermore, Pashtun tribal areas were allowed to police themselves. This differential treatment indicates that early on, the privilege of policing was granted to those local elites who were important for the stability of the central government.

Even in the Republic under Daud (1973-1978), state policing did not enable the state to constantly monitor the whole population or to tax it efficiently, but it was effective in stabilizing the country.

The MoI was able to enforce compliance when needed and with minimal effort. Former police officers and elders agreed that the appearance of a lone policeman armed with a stick was enough to prompt villagers into cooperation and suspects would be handed over without resistance. Even khans could be arrested peacefully, including sometimes in places like Kandahar where even in the 1970s they had retinues of armed men around them. The khans never challenged the police and relied instead on negotiations and political patronage to get out of prison.

However, this was not so much the result of respect or fear of the police per se, but of the knowledge that resistance would lead to the intervention of the army. (Giustozzi and Isaqzadeh 2013: 18) 
Only in 1973, there was for the first time a national Police Law. The number of total police forces varied between 15,000 and 30,000, meaning that at the district level they operated in teams of 3 to 15 officers (Giustozzi and Isaqzadeh 2013: 18-19). Thus, "[..] most villages only saw traces of the police once every several months, if not even less often" (Giustozzi and Isaqzadeh 2013: 20). While the police force was thinly spread, it acted as the eyes of the central government. However, the police' law enforcement capacity was very limited because the state was not strong enough to abolish self-help communities. As a consequence, the Afghan state had developed a form of governance in which the tribes mostly ruled themselves, while the district government sustained a balance of power between the tribes. The power of the tribal leaders was based mostly on tradition as well as on control over land. Policing was done by the communities themselves, either through village elders or tribal leaders, and a combination of tribal customs, Sharia and state law was applied (Malkasian 2013: 8-13). As Malkasian shows for one district in the Afghan south, "[t] he government depended on the tribes. Tribal leaders retained armed guards who helped the police detain criminals" (Malkasian 2013: 9).

To sum up, the state in Afghanistan has never been strong enough to monopolize the regulation of small-scale violence. Thus, when the period of civil war and Taliban conquest began in 1991, the self-help communities were the most important small-scale violence institutions for most Afghans.

\section{Step One: Self-Help Community Resilience}

In the absence of a strong state, self-help communities have remained the main regulators of small-scale violence. Since these institutions have developed over decades and people have been socialized into non-state systems of small-scale violence regulation, self-help communities have displayed great resilience during the civil wars and were thus the dominant form of small-scale violence regulation in the early 2000s. Accordingly, local elites who ruled self-help communities were in a powerful position when the statebuilding intervention began. The following paragraphs will provide illustrations of the how self-help communities

Due to the absence of a state during the last centuries, villages (where today about $80 \%$ of the population lives) had to rely on their self-organizing abilities (Murtazashvili 2014: 4). Self- 
help communities form several layer of governance, and they work differently in various areas of Afghanistan. The smallest social unit is often referred to as qawm and can be a family, a village or some tribal community (Rubin 1995: 25). Across Afghanistan, local jirgas or shuras have become a non-state institution of small-scale violence regulation. Everyday life is to a large extent governed by informal or customary rules (Wardak and Braithwaite 2013: 199-201). Thus, the informal justice system is the dominant mechanism to deal with private conflicts in Afghanistan (Coburn 2013: 12-13). Koehler (2012: 12-13) argues that the degree of governance provided by institutions in Afghanistan diminishes the greater the scope of institutions. The local elites who rule the self-help communities are called maliks, mullahs or commanders, and they are not always 'traditional' leaders. Due to the long civil war in Afghanistan, local rule has been partly militarized and tribal networks have been disrupted. Thus, power and legitimacy have been transformed through the dynamics of civil war. Many tribal or village elders whose legitimacy was based on tradition were increasingly displaced by 'commanders'. These new local leaders derived their legitimacy mainly through their ability to command small groups of armed men and, thus, offer a higher degree of security and order (Wilde and Mielke 2013: 360-361).

As this discussion shows, the local elites in Afghanistan were not leaders of criminal gangs, or ad hoc militias or neighborhood watches (as was the case in Bosnia-Herzegovina). Their power bases were local institutions of small-scale violence regulation that developed over decades (e.g. commander polity) or centuries (e.g. village, tribe). Due to their strong local roots, these actors and their institutions were able to outlast the most ambitious monopolization effort that had occurred prior to NATO's intervention: The Soviet's attempts to build a modern state in Afghanistan. In 1979, the PDPA government had quickly politicized the police by abandoning meritocracy and bringing politically loyal individuals into the leadership. In the face of armed revolt, the police force suffered a wave of defections (Giustozzi and Isaqzadeh 2013: 25). Of the aforementioned police force only 5,000 to 6,000 officers had remained in service at the time when the USSR intervened. Under Soviet supervision, the police forces were rebuilt and reprofessionalized. Its overall size was massively expanded to 96,700 in 1988, and it grew further to over 100,000 in 1991 when the Najibullah regime collapsed (Giustozzi and Isaqzadeh 2013: 32). The Soviet statebuilding project in Afghanistan began with great ambition, but after years of heavy military casualties and hundreds of thousands of dead civilian, the USSR changed its course in 1986. It abandoned efforts to monopolize the use of force and to bureaucratize state 
rule. In 1987, this shift was underlined by a new constitution that went back to traditional institutions such as Islam and the Loya Jirga, and by a change in personnel. Najibullah became the new President, who would subsequently start negotiating ceasefires with various mujahedin commanders (Hess 2010: 177-178). As the example of the Najibullah regime shows, patrimonialism could guarantee a degree of stability as long as the central government had enough funds to pay its clients (Hess 2010: 177-181). By February 1989, the Soviets had with withdrawn. The state they left behind was highly neopatrimonial, relying on the payment of local commanders and other elites to manage of the risk of a coup.

At the end of the socialist experiment, the government had at its disposal the biggest police force the country had ever seen. When the funding from Russia dried up, it became apparent that this large repressive apparatus was not sustainable. The Afghan police completely dissolved with the end of the Najibullah regime (Hess 2010). The Police Academy in Kabul closed during the mujahedins' battles for the city, and police forces either dissolved or came under control of regional warlords. "[...] when the Afghan state collapsed following the Soviet invasion, social order continued to exist in Afghan rural villages, where the overwhelming majority of Afghans live" (Wardak and Braithwaite 2013: 198). Once the Taliban had taken control over most of Afghanistan, the police was further de-professionalized. Policing was mostly conducted by Taliban fighters, and professional policemen were accused of being communists and quit the service. Especially in the South, the Taliban disempowered the village elders and tried to concentrate power in the hands of local religious elites (Malkasian 2013: 72-75) Nevertheless, the Taliban system was effective in creating a degree of stability through the combination of local policing and threats from the central government to use force in case of noncompliance (Giustozzi and Isaqzadeh 2013: 34-35). Summing up the monopolization efforts of both the Soviets and the Taliban, their approaches differed in many respects but the outcome was the same: A return of the elites and institutions that had been in place beforehand.

These patterns can be found across Afghan provinces, although the type of self-help community varies according to the region. In Kandahar and Helmand, social structures are more homogenous than in the north or west, and many traditional institutions are still in place. Major power networks are centered on the two Pashtun 'meta-tribes', the Durrani and Popolzai. In Helmand's 
Garmser district, the ruling (Durrani) tribes traditionally were the Alizai and Noorzai who settled there under Durrani's rule in the $18^{\text {th }}$ century (Malkasian 2013: 2-3). In their short reign over Afghanistan, the Taliban tried to sideline self-help communities by empowering religious leaders. However, once that system had collapsed in late 2001, the same elders and tribal leader who were in power reasserted their control (Malkasian 2013: 72-75). In many Pasthun villages of the Southeast, local shuras controlled policing of the village, which was conducted by tribal police (arbakai). These Arbakai were not permanent organizations like state police or militias, but are convened on an ad hoc basis to deal with conflicts (Schmeidl and Karokhail 2009: 320-322).

In northern Afghanistan, traditional structures had been partly replaced by new self-help communities that were led by so-called mujahedin commanders. Thus, the equivalent to the metatribes of the South is the mujahedin parties. The example of Kunduz province is instructive as its social structure had been in flux since resettlement policies started in the late $19^{\text {th }}$ century (Schetter et al. 2006: 7-9). Compared to their peers in the Pashtun regions, the Northern powerbrokers of the post-Taliban era were important players 'only' for several decades before NATO's intervention. As Schetter et al. (2006: 9) observe:

"[..] a high variety of warlords and 'big men', who differ widely in the scope of influence and power, are controlling the means of physical violence in Kunduz province. Moreover a complete lack of religious, ethnic-tribal or even modern institutions can be observed which are capable to constrain the arbitrary of the rulers. This results in a strong localisation of the 'rules of the game' and varying architectures of the power structure from district to district, and as in Khanabad district from village to village. Additionally, the rentier economy of large landlords strengthens the position of the warlords, makes them independent from the population and further weakens the existing collective institutions."

At the time when NATO intervened in Afghanistan, the most powerful local commander in Kunduz was Mir Alam, who was a member of Shura-i Nazar. He rose to power in Kunduz during the 1990s, when different Jamiat factions battled each other. During the Taliban reign, local offices were given to those commanders who defected, while Mir Alam fought for Shura-i Nazar, and alongside Junbesh, against the Taliban (Münch 2013: 10-11). Thus, "[a]fter 2001, Mir Alam successfully recovered his fiefdom [..] and became the strongest single military commander of 
Kunduz" (Münch 2013: 11). Similarly, the Ibrahimi family, which belonged to the Hezb mujahedin faction and switched sides repeatedly during the Taliban era, were powerful enough to emerge as a major force in the post-2001 period. Their authority rested less on coercive capacities and more on their control over access to markets and water in their district (Münch 2013: 11-12). A third major actor was Daud Daud, who became an important powerbroker under Massoud and, thus, was very well connected within Shura-i Nazar. Thus, the individuals and networks that controlled the North after the fall of the Taliban were the same that already fought against the PDPA government and the Soviets. Consequently, policing in the countryside was conducted by local commanders and their organizations, while the larger warlord polities held greater sway in the cities (Schetter et al. 2006: 8-9).

Overall, despite efforts by the Soviet Union and the Taliban to sideline these institutions, small-scale violence in Afghanistan was regulated by different kinds of self-help communities throughout the decades of civil war. When Karzai became interim President, he used the few resources he had to build a patrimonial central government which relied on power-sharing with major factions. The result was a complex power structure that existed when the statebuilding intervention commenced.

\section{Step Two: Government Dependence on Local Elites}

At the beginning of the statebuilding intervention, a new government and new institutions were created. This section shows that those who became central state elites were highly dependent on local elites. Hence, before the statebuilding effort could engage in monopolization, the actors who controlled small-scale violence regulation had already seized the power in the new state.

As the last section has argued, the mujahedin parties of the north as well as the meta-tribes of the south are essentially macro-level alliances of local self-help communities. When the Taliban were defeated in 2002, the control over small-scale violence regulation shifted back to those who had always been local elites. The powerbase of the Northern Alliance warlords were the many local commanders at the local level: "Until 2005 AMF fighters received a salary, and even though they were part of a national army, they remained de facto under the control of their Jihadi or civil war period commander" (Koehler and Gosztonyi 2014: 236). In the early phase of 
statebuilding in Afghanistan, the government had to rely on these local elites and effectively integrated them into the state. While DDR should have been targeted not only at warlords but also at district level strongmen, "[..] the demobilization of armed mujahedin units. [..] 'pushed' compliant commanders into political and parliamentary positions that permitted them to legally retain armed followers as bodyguards" (Koehler and Gosztonyi 2014: 233).

In the immediate aftermath of the Taliban regime, the new government was characterized by a power-sharing arrangement between former military elites and technocrats. Warlord polities such as Jami'at (Ismail Khan), Junbesh (Rashid Dostum) and Shura-I Nezar (Mohammad Fahim) tried to seize the government, as did those technocrats around Karzai who had the support of foreign donors (Giustozzi 2009). Western support tipped the balance of power in favor of Karzai, but in order to stabilize the country he integrated the warlords by giving them different ministries and granting them great autonomy in their respective regions (Mac Ginty 2010b: 588-589). Among them, Minister of Defense Fahim was the central link between the Northern networks (especially the Panjshiris) and the new government in Kabul. In a form of division of labor, Karzai took care of building up a patronage network into Southern Afghanistan through his good connection with the Durrani tribe(s) and the elites of Kandahar, Afghanistan's second city. Overall, the government could do little to build effective formal institutions and thus created a centralized patronage-based state that disarmed the major militias to a certain degree (Giustozzi 2009: 89-94).

These groups are still structuring much of the local politics in parts of the country. While their means of large-scale violence were appropriated by the state through the dissolution of the AMF, they still have powerful networks at the local and provincial levels, as well as into the central government (Münch 2013). In the South, the large tribal networks have a similar function as the former United Front parties in the North. While they are not cohesive organizations, the (meta-)tribal structures nonetheless facilitated networking between elites on different levels. During the last two century, members of the Pashtun Durrani tribe (Ahmad Shah Durrani, Mullah Omar, Hamid Karzai), and the Durrani-affiliated Barakzai tribe (Abdur Rahman, Mohammad Zahir Shah), have dominated Afghan politics.

Local elites were the crucial links that connected local institutions of small-scale violence regulation to the central government in Kabul after the ousting of the Taliban regime. Especially 
the former mujahedin factions and the warlord polities of the North have created lasting legacies. These institutions emerged during the 1970s and 1980s as resistance movements against the socialist governments. Organized like political parties, they were often led by charismatic leaders such as Ahmed Shah Massoud or Ismail Khan. These proto-states, commanding tens of thousands of troops, and controlling whole regions of Afghanistan, were heavily weakened during the Taliban regime of the 1990s, so that the only significant organization that was left in 2001 was Massoud's Shura-i Nazar (about 16,000 troops) (Giustozzi 2009).

The direct links between the national level and the local self-help communities can be exemplified again by looking at specific districts and provinces. Here, formal institutions were created immediately while it would take several years until ISAF trained and equipped the ANP so that it could be deployed in sufficient numbers to the provinces. In Kunduz province, the office of police chief was given to a Pashtun affiliated with the Ittehad faction in 2002 (Münch 2013: 14-15). In 2004, in the run up to Presidential elections, and with increased government power through the ISAF PRT Kunduz, the office was given to member of Junbesh (Münch 2013: 21). Similarly, the introduction of formal state policing in Helmand province was captured by local politics. Between 2001 and 2005, the office of provincial chief of police of Helmand was held by Abdur Rahman Jan, a warlord from Marjah. Under his rule, the ANP was mainly a tool to extort money from the population. District CoPs were instated by Abdur Rahman Jan and would in return give some of the 'taxes' he collected to his provincial CoP. In return, the ANP would do little to provide safety to the population and, thus, they were seen as tool of mere repression. Worse, the warlords who took over the provincial governor and the chief of NDS posts were fighting each other (Farrell and Giustozzi 2013: 847-848). The next session will discuss in detail how the capacity-building efforts of ISAF affected self-help communities.

To sum up, the intervention defeated the Taliban and led to the creation of formal institutions. However, the central government lacked a police force while local elites could base their power on the self-help communities which had outlived the decades of civil war. As a result, the new state had to rely on the local elites for the maintenance of order. 


\section{Step Three: Capacity-Building without Monopolization}

This section shows how ISAF helped the Afghan government to build a large police force. However, due to the power of local elites, the statebuilders were unable to replace self-help communities. Thus, the state capacity-building was not accompanied by a monopolization of small-scale violence regulation.

The creation and expansion of the Afghan National Police was one of the central pillars of ISAF's statebuilding efforts. From the very beginning of the new Afghan polity, the international community supported the establishment of a modern police organization that would be accountable and bound by the rule of law. In 2002, police training started in Afghanistan as a small-scale effort by Germany to train a new police leadership in Kabul. A small team of German police officers trained Afghan police officers in order to establish an ANP leadership that can live up to Western standards of professional and accountable policing. The German approach put strong emphasis on historic continuity, as it was centered around the re-launch of the Kabul police academy and the continuation of the decade-old (though repeatedly interrupted) AfghanGerman police cooperation. This very modest program was increasingly accompanied by US training of rank-and-file police officers in regional training centers (Giustozzi and Isaqzadeh 2013: 48-49). Two problems arose from this approach. First, the number of police officers increased very slowly, which deprived the state of personnel to be active in all areas of Afghanistan. Second, the police quickly became a major target for the Taliban insurgency. Since police forces are the local face of government, and because they are only lightly armed, they represent a very valuable target for insurgents.

With the increasing expansion of the intervention, the approach shifted from low numbers and leadership training towards greater numbers and paramilitarization. The US slowly took over from Germany (and the European EUPOL), and "[..] transferred responsibility for the Afghan police assistance program from the Department of State to the [Department of Defense]" (Planty and Perito 2013: 2). Thousands of US soldiers and PMCs were mobilized to train police officers, and the ANP pay system was improved in order to combat corruption (Murray 2007: 113). "By early 2010, the ANP was present in all 34 provinces, six of which were deemed medium-threat and ten high-threat areas" (Friesendorf 2011: 88). Thus, fielding the police force into all provinces took about eight years, and this does not mean that the police had been deployed into 
every district, let alone every village. Overall, the number of police forces has increased from about 60,000 in 2005 to over 150,000 in 2013 (NATO 2013a).

In response to the problems of corruption, state-capture and high attrition rates on the level of local policing, ISAF re-arranged its police-building mission in 2007 by introducing the Focused District Development (FDD) program. The idea behind the program was that training single police officers and reinserting them into their deficient units would do little to change the organizational culture. Hence, in the FDD program ANP units were taken out of their district as a whole in order to form local police units that were less corrupt und less prone to desertion (Giustozzi and Isaqzadeh 2013: 50-51). However, FDD also had a very strong focus on paramilitary training.

Seven out of the eight weeks of the FDD curriculum were devoted to military tactics, with basic police skills given a one-week slot. Regular ANP officers therefore learned little about policing ethics, criminal procedures, the Afghan constitution or human rights, especially after November 2008, when training on community and democratic policing, as well as domestic violence and women's rights, was removed from the FDD curriculum and replaced by military training. (Friesendorf 2011: 86)

The expansion of state policing was accompanied by efforts to create an effective Ministry of Interior. However, as leadership positions in the MoI are important for the balance of power between the different factions in the country, reform of the MoI has been difficult. Unlike in the MoD, there was very little continuity in MoI in terms of leadership. Between 2001 and 2014, eight different ministers were in charge of the department. Ambitious ministers like Ali Ahmad Jalali or Hanif Atmar, whose reforms threatened the patrimonial network of the Karzai government, were blocked by the president (Giustozzi and Isaqzadeh 2013: 135-136; 141-142).

Given the power of non-state actors in the provinces, the Minister of Interior had to constantly balance reform efforts that aimed at bureaucratizing the police and centralizing internal security with the need to accommodate local elites. One of the actors most aware for the need to satisfy all factions is President Karzai, who sacked MoIs whose anti-corruption efforts could threaten the broader ruling elite alliance. The ANP leadership of many provinces and districts is staffed by local strongmen who have worked for regional warlords in the past. A survey by Giustozzi and Isaqzadeh (Giustozzi and Isaqzadeh 2013: 119-120) shows that out of 
the police chiefs of the ten most populous provinces in April 2011, seven were former mujahedin commanders. Five of these provincial police chiefs were affiliated with Jamiat, the former mujahedin group that fought both against the Soviets and the Taliban. At the same time, the central government is very active in assigning and rotating police chiefs both at the provincial and district level. In order to balance the different factions on the local level and secure support in elections, Karzai frequently reshuffles offices among the local elites (Giustozzi and Orsini 2009: 10-13).

However, eventually the statebuilders came to the conclusion that they needed the local elites to create a modicum of social order. In order to strengthen them and bind them to the state, a large militia program was initiated. The inability to deploy a sufficient number of police officers to remote rural areas and, crucially, to control them, has led the Karzai government to reconsider its stance towards militias. In order to relieve the ANP and to reduce the sway of the Taliban, the government has created the Afghan Local Police (ALP). The ALP program funds local-level militias that declare themselves willing to work with the government. It was set up in August 2010 and is controlled by the MoI. Within only three years, the number of ALP fighters has surpassed the 20,000 threshold, and the goal is to arm forty-five thousand militiamen by 2015 (Goodhand and Hakimi 2014: 14-15). While initially a skeptic, President Karzai and his MoD increasingly saw the ALP as a cheap tool to extent both state power and personal patronage networks into rural and contested areas (Goodhand and Hakimi 2014: 16). The creation of the ALP was a compromise that was struck in the hope that a greater official role for self-help communities would increase their loyalty to the state. While ALPs are formally commanded by the district's Chief of Police, they enjoy in fact a great degree of autonomy (Koehler and Gosztonyi 2014: 240-241). Compared to regular ANP, the ALP personnel receives only a very limited training. Their main task is not to enforce national law, but to defend local communities against Taliban infiltration. Hence, the ALP is the cheapest form of increasing manpower against an insurgency. However, the government has little control over these units, and there are widespread reports about abuse of their power by taxing and harassing the population (Goodhand and Hakimi 2014: 40). The whole strategy underlines that the central government is well aware of the power of local actors, and tries to tap into their authority by creating patron-client relationships on a grand scale. 
Politically, the growing power of the local elites has been accompanied by a return of the Loya Jirga. National level jirgas had not been summoned after the Emergency Loya Jirga 2002 and the Consitutional Jirga 2003. However, since 2009 Karzai has gathered two Loya Jirgas. The purpose of the first one in 2010 was to discuss the potential for reconciliation with the Taliban. Crucially, he invited Taliban leaders themselves to join the Jirga. The second Jirga was consulted to make a decision on the Bilateral Security Agreement which was supposed to regulate the status of foreign forces after ISAF. By gathering tribal leaders and other informal elites in Loya Jirgas, Karzai weakens the formal institutions of the state and strengthens non-state actors. It is thus a turn away from externally supported parliaments to traditional sources of power. As Schetter (2003: 214-216) argues, these gathering should not be mistaken for true democratic participation of local elites. Since the formation of the Afghan state, national leaders have used Jirgas to legitimize their decisions. Overall, Karzai has used the traditional assemblies to distance himself from external actors and to accommodate both rural elites and the Taliban.

A look at the provincial and local level helps to understand the dynamics at play. Both in the North and in the South, local elites retained a strong powerbase. When state institutions expanded to the local level, non-state actors did not give up their power over small-scale violence regulation but would either compete with the state or capture public offices. In Helmand, the tyrannical rule of the warlord and provincial Chief of Police Abdur Rahman Jan was ended when ISAF deployed to the region and public offices were reshuffled in 2005. Later that year, governor Sher Mohammad Akhundzada was dismissed due to NATO pressure on the central government. However, replacing the provincial chief of police and the provincial governor meant that "[..] the de facto powerbrokers in the province were replaced in their de jure provincial positions" (Martin 2011: 52-53). Abdur Rahman Jan kept his militia and took advantage of the growing drug market. Attempts by ISAF to eradicate poppy in 2008 were thus met with stiff resistance. "Through his patronage network, [Abdur Rahman Jan] still controlled most of the police in central Helmand. He retaliated by allowing the Taliban to enter and take control of Marjah" (Farrell and Giustozzi 2013: 852). After being released from the office of provincial governor, Sher Mohammad Akhundzada responded in similar fashion. In a newspaper interview he later claimed that: "When I was no longer governor the government stopped paying for the people who supported me. [..] I sent 3,000 of them off to the Taliban because I could not afford to support them but the Taliban 
was making payments" (Telegraph 2009). Hence, attempts to take out local elites and replaced them with a small-scale violence regulation regime that is centered on formal policing and professionalism in public offices had strong implications for local politics. Due to the availability of the Taliban as an alternative patron, local elites could retaliate against the monopolization attempts of the statebuilders.

In the North, the German-led police-building had greatly expanded in line with the broader ISAF approach: "in 2009 the three German Police Training Centres of the north-east (located in Mazar-e Sharif, Kunduz and Fayzabad) trained a total of 4,000 police" (Koehler and Gosztonyi 2014: 239). In Kunduz, after an internationally-led Rank Reform Commission suggested that the current police chief was too corrupt, Karzai replaced him with more professional personnel in 2006. However, while the two police chiefs between 2006 and 2010 enjoyed the legitimacy of (German) ISAF forces because they were seen as professional and less corrupted, they were also ineffective in reducing the Taliban infiltration of self-help communities across the province (Münch 2013: 31). When the control over public police offices in the North in general and in Kunduz in particular was given back to powerful local commanders from Shurai Nazar in late 2010, these new police chiefs used their connections with the Ministry of Defense to request more personnel. At the same time, they proved much more effective in organizing control of insurgency-threatened areas and were able to increase the state's presence (Münch 2013: 40-41). There were also powerbrokers in the province who had rarely access to public offices, but still commanded small groups of armed men and controlled substantial economic resources. The most influential of these was Mir Alam of Shura-i Nazar, who clashed with ANP several times. Ironically, he was later accommodated by receiving money from a joint program by US forces and the NDS, which channeled money and weapons towards 'community defense' forces in order to fight the Taliban (Münch 2013: 36-38). Mir Alams militia was thus strengthened vis-à-vis the official forces in a program that became one of the forerunners of a nation-wide militia-building effort. "In the case of the north-east, the setting up of these militias was supported by the governors of these provinces, the National Directorate of Security (NDS) and the police (ANP). They were mostly organized along former Jihadi party lines" (Koehler and Gosztonyi 2014: 238). In sum, the constant wrestling between the government and the Taliban has further increased the leverage of local elites who hedge their bets by supporting those actors of large-scale violence that appear to be stronger. 
To sum up, the expansion of formal policing across the state territory has not replaced informal policing. The government lacked the leverage to take the privilege of policing from local powerbrokers. Instead, it had to tolerate the existence of non-state policing institutions, and it also used formal police offices as rewards for those local elites who cooperated with the central government. Thus, instead of monopolizing the means of small-scale violence, the interaction of local elites and the central government led to a fragmentation of policing.

\section{Outcome: Para State}

At the end of ISAF in 2014, there was no state monopoly on small-scale violence regulation in those areas that were not under Taliban control. While the ANP has grown to be the biggest police force Afghanistan has ever seen, self-help communities have persisted. At the same time, the local elites that control these institutions have strong influence on the central government. Furthermore, due to the lack of formal integration of local communities into the state apparatus, local elites have taken over formal police and governor offices. While this has increased the police effectiveness in some cases, it has also made the police a partisan tool in the hand of local powerbrokers.

For Afghans, the simultaneous existence of state and non-state institutions of small-scale violence regulation has created a complex situation at the local level. A study by the Asia Foundation in 2013 asked respondents whom they report crimes to. People did report crimes to a variety of state institutions such as the ANP (26\%), district governor (11\%), ANA (10\%), provincial authority $(3 \%)$, public prosecutor $(3 \%)$, or courts $(2 \%)$. Overall, $55 \%$ of crimes were reported to these various state institutions. However one has to keep in mind that many officeholders are also informal powerbrokers. The same survey shows that many people still turn to the shura/elders (18\%), tribal leader (12\%), or Mullah Sahib (5\%) (AsiaFoundation 2013: 35). Furthermore, in the broader category of dispute settlement, people rely on the local state courts $(36 \%)$ as well as on the courts of self-help communities (36\%), and many issue are brought before both court systems (24\%) (AsiaFoundation 2013: 84). 


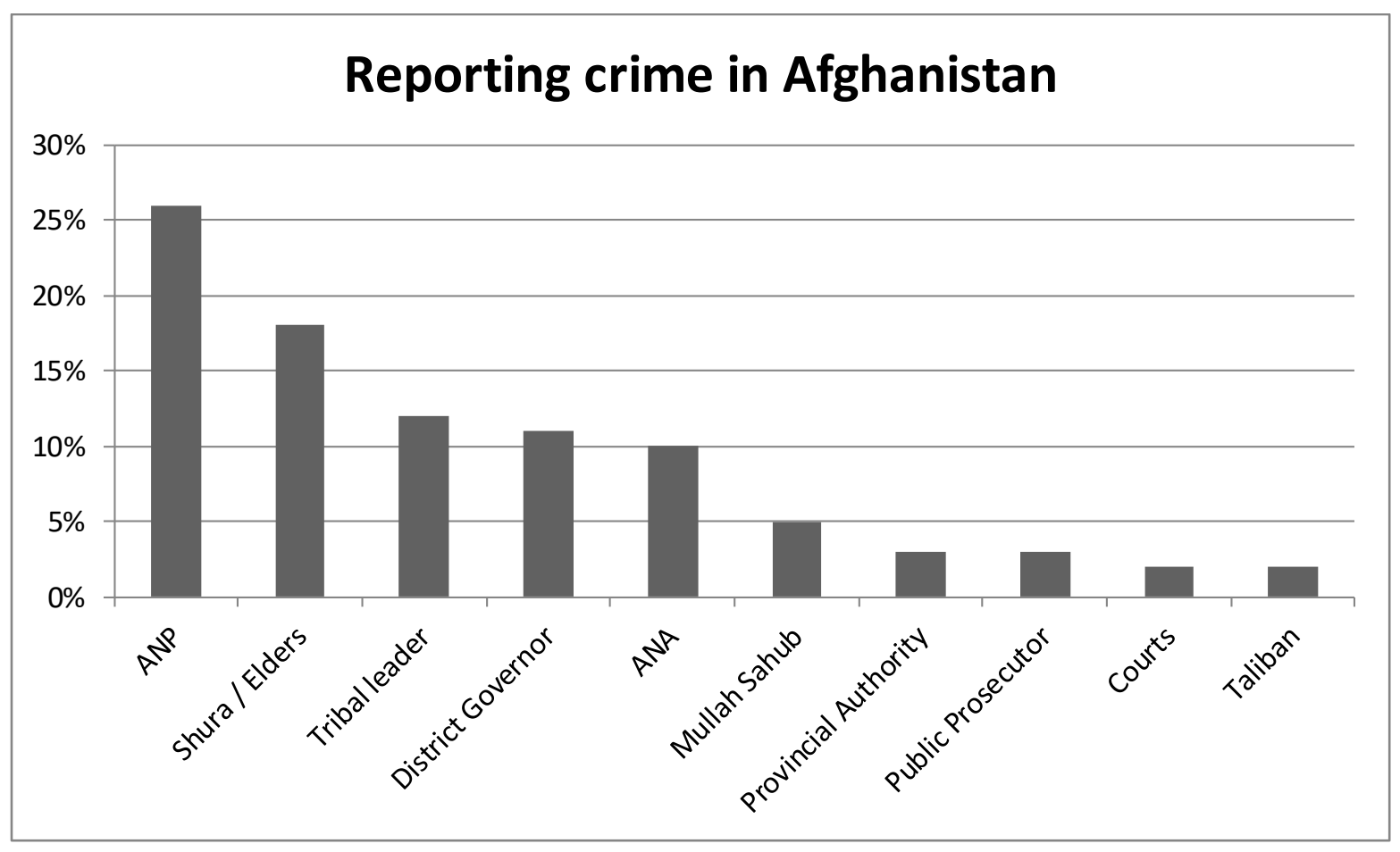

Figure 13: Answers to the question "Who did you report the crime to?". Figure reproduced from Afghan Survey 2013, The Asia Foundation (AsiaFoundation 2013: 35).

Given the common criticism by scholars and international organizations who see the police as too corrupt and too paramilitarized, the population has a rather positive view of the ANP. A representative survey conducted by Boehnke, Koehler and Zuercher (Boehnke et al. forthcoming) in 2007-2013 shows how North-Eastern Afghan ${ }^{22}$ s evaluate the ANP. Although the results of surveys from war zones have to be taken with a grain of salt, the data helps to get a sense of the relation between police and population. Overall, the study shows that the population embraces the ANP despite all its shortcomings as a policing organization (fig. 14). This indicates that it is not the weakness of the Afghan police but the strength of its competitors that has prevented the state from monopolizing small-scale violence regulation. Furthermore, the data shows a dip in favorable views in 2011 (fig. 15). Since 2010 was the peak year of ISAF's counterinsurgency campaign in the north, the data might reflect public sentiments against the aggressive style with which the security forces hunted down Taliban in the North. At the same time, many people (54\%) still believe that local commanders will provide security if ANSF retreat and fear of

${ }^{22}$ The survey was conducted in the districts Aliabad, Imam Sahib (both Kunduz), Taloqan, Warsaj (both Takhar), Yaftal and Jurm (both Badakhzan). 
militias has been declining since they were integrated into the ALP (Koehler and Gosztonyi 2014: 244-247).

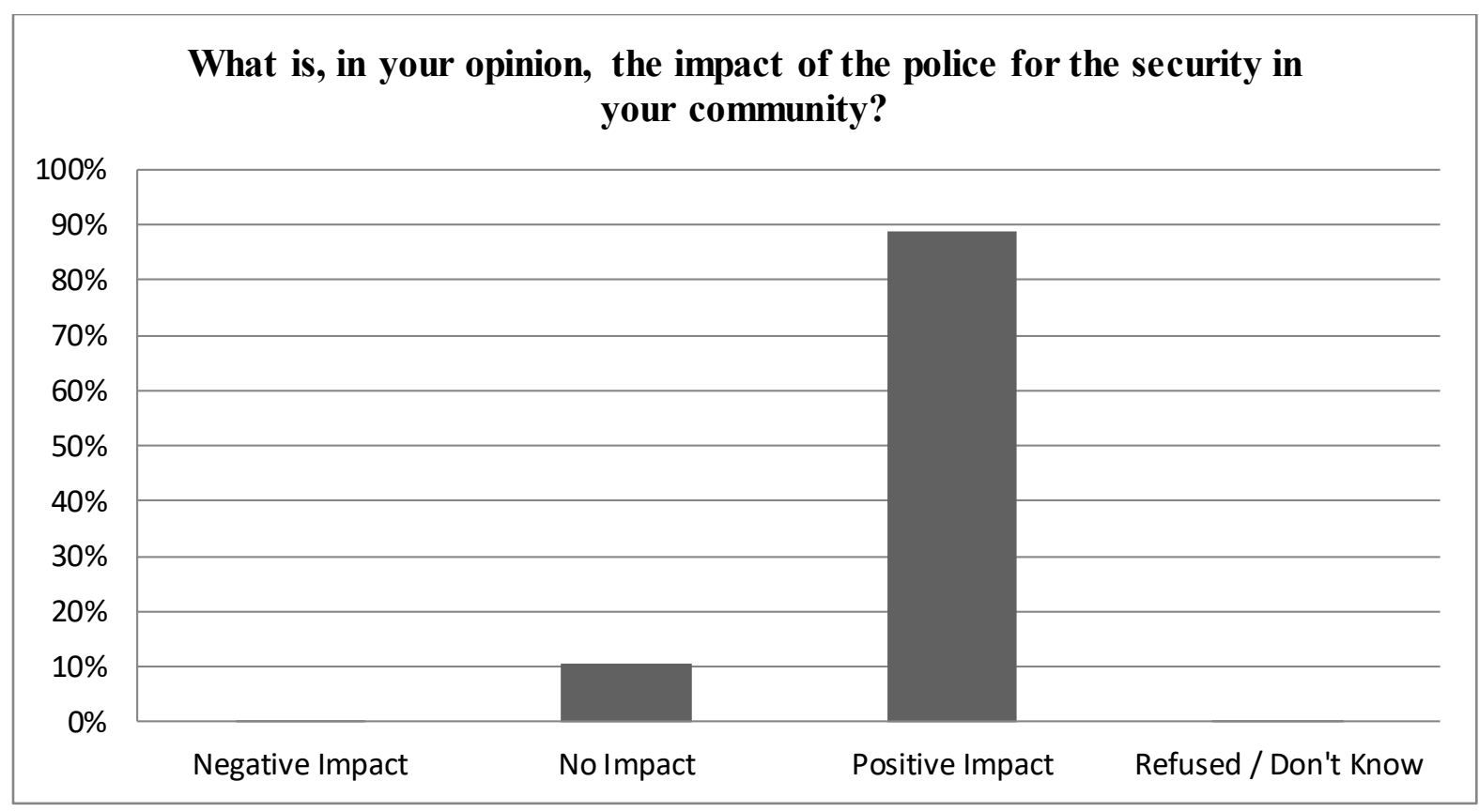

Figure 14: Question on attitude towards the ANP in 2013, item from Northeast Afghanistan Longitudinal Study (Boehnke et al. forthcoming). 


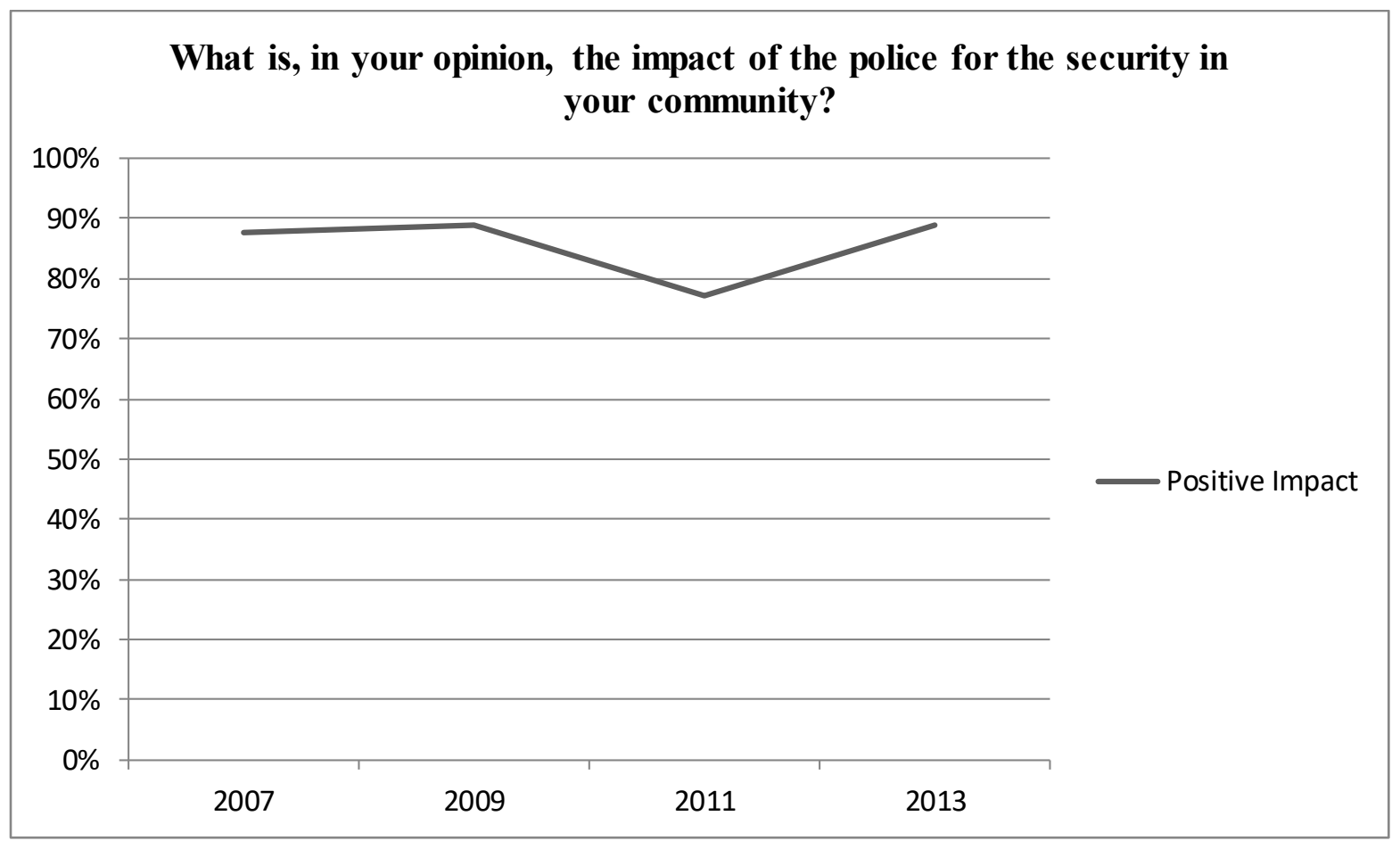

Figure 15: Question on attitude towards the ANP, item from Northeast Afghanistan Longitudinal Study (Boehnke et al. forthcoming).

As the case study also shows, the introduction and strengthening of police forces tends to shift the balance of power at the local (district) level. Where several strongmen compete for control over the population, the central government can generate leverage from distributing police offices. At the same time, this form of patronage undermines professionalization and turns police districts into local fiefdoms. Furthermore, the links between local and national elites is often more fluid than the distinction between these levels suggests. Networks such as tribes or former mujahedin parties connect local policing powers directly to the national elites in the Ministry of Interior and to the President. Last but not least, this type of divide-and-conquer politics opens up spaces for armed groups who can become more reliable partners of local elites.

\subsection{Conclusion}

ISAF has failed to create an Afghan state with a monopoly on violence. If we take the gap between the situation in 2001 and the postulated goals of ISAF, the intervention in Afghanistan 
can be seen as the most ambitious statebuilding mission so far. However, great ambition can lead to great failure. Despite immense efforts to build a strong liberal state, Afghanistan was neither at the end of NATO's ISAF mission. The attempt to monopolize violence regulation has failed despite the fact that the Afghan state today has the strongest organizational capacities in its history. Nevertheless, at the level of large-scale violence, the Taliban and its allies have demonstrated their capability to inflict casualties to the Afghan National Security Forces at a rate that must be described as open warfare. The result has been a fragmented state whose territory is partly under government and partly under armed group control. At the level of small-scale violence, self-help communities have shown great resilience towards monopolization as local elites have captures the state or have worked with the Taliban. Thus, where the government rules it does so through a form of para state.

The chapter has offered explanations for these outcomes. The failure to create a monopoly on large-scale violence stems from the competition of key regional states over influence in Afghanistan. India and Pakistan have both invested a lot in Afghanistan, but due to their decadeold rivalry, their goals are highly divergent. As the process-tracing analysis has shown, there is a clear causal link between this regional competition and the resulting failure to build a monopoly on large-scale violence. Pakistan's (indirect) support for the Taliban insurgency enables the rebel group to sustain their organization. The Taliban's continued resistance has driven up the costs of monopolization to a point where NATO members decided to retreat in the absence of a state monopoly on large-scale violence.

There seems to be little that can be done about the regional constellation. There is no regional institution that could facilitate cooperation between key states in Central and South Asia, and NATO is not powerful enough to fundamentally alter Pakistan's stance towards Afghanistan. The findings of this case study do not implicate that Afghanistan will not succeed in monopolizing the means of large-scale violence. After all, it is possible that the central government will defeat the Taliban at some point in the future with external assistance and against the will of Pakistan. What the chapter has demonstrated is that it's implausible to assume that Pakistan is just unable to secure its borders. After all, the main operations of the Quetta Shura Taliban are conducted not from the tribal areas but from Baluchistan. At the same time, Pakistan conducted warfare against some of its tribes (TTP) while sparing the Haqqani Network. 
With regard to the creation a state monopoly on small-scale violence, the legacies of a long history of weak statehood have prevented the statebuilding intervention from succeeding. Afghanistan has been an independent state for about a century, but it has never had a strong central government. As the chapter argued, this resulted in strong self-help communities regulating the lives of most Afghans. With strong institutions come strong local elites who have a lot to lose from a state seeking to replace self-help communities with formal government structures. Thus, despite massive investments by the international actors to strengthen governments and police at all levels, the old elites have managed to capture the formal institutions with their personal networks. As a result, a combination of corrupt police forces and self-help communities regulate everyday life in Afghanistan. What distinguishes Afghanistan from the case of Sierra Leone is the ongoing civil war. Not only do local elites use their self-help communities as powerbases and sources of revenue. In areas that are contested between the government and the Taliban, strongmen can bargain for more resources by threatening to shift support to the other side in the civil war. Hence, the absence of a state monopoly on large-scale violence only increases the power of small-scale violence actors.

Overall, the Afghanistan shows the clear limitations of what statebuilding interventions can achieve. The case lacked both conditions that would have been necessary to turn the intervention into a success. In the following chapter, I will analyze a case in which statebuilding has resulted in a para state: Sierra Leone. 


\section{Sierra Leone}

The statebuilding mission in Sierra Leone began in 2000 when the UN decided to transform its peacekeeping operation into a more ambitious peacebuilding effort. At this point, Sierra Leone had become a synonym for concepts such as 'state failure' and 'new wars' due to its civil war that had begun in 1991. The globally broadcasted pictures of machete-wielding, drugged child soldiers shaped a picture of Africa as a place where Hobbesian anarchy prevails and life is 'nasty, brutish and short' (Keen 2005: 3). Given the scope conditions, including an ongoing and devastating transnational civil war, a history of weak statehood, ethnic heterogeneity, and extreme poverty, prospects for successful statebuilding were bleak. Peace treaties were regularly violated, and a wide range of actors (army factions, militias, PMCs, regional forces) had become part of a complex conflict. Nonetheless, Sierra Leone turned into a showcase of externally-led statebuilding. In 2000, when the UN sent troops to enforce peace in Sierra Leone, the state institutions had mostly ceased to exist. However, within few years, the RUF insurgency was defeated and the government regained control over the state's territory. By the end of 2005, the UN Mission in Sierra Leone (UNAMSIL) had completely withdrawn its troops and the state enjoyed a monopoly on large-scale violence. This monopoly was further stabilized by elections in 2007 and 2013, one of which saw a peaceful transition of government from the Sierra Leonean People's Party (SLPP) to the All People Congress (APC). The statebuilding intervention in Sierra Leone not only succeeded in creating a monopoly on large-scale violence, it even transformed the country into an electoral democracy. At the same time, small-scale violence in most parts of the country is still mainly governed by chieftaincies, with local governments and police only complementing self-help communities. In sum, the intervention has failed to create a full monopoly on violence. This case study explains why the statebuilding intervention in Sierra Leone succeeded in creating a monopoly on large-scale violence, while failing to establish a state monopoly small-scale violence regulation.

The explanation for the success in monopolizing the means of large-scale violence can be found in the support for UNAMSIL by key regional actors. As this chapter will show, the intervention succeeded in creating a monopoly on large-scale violence because it had the support of ECOWAS, specifically of Ghana, Guinea, and Nigeria. Their support for the statebuilding intervention made it possible to cut off the Revolutionary United Front's (RUF) supply routes 
which ran through Liberia, thereby forcing the armed group to seek a political settlement. As a result, the intervention led to the complete disarmament of the RUF within the following two years. Meanwhile, the external actors supported the government in disarming militias and rebuilding its national security forces. The re-establishment of the army as a small but professional force made an institutionalized monopoly on violence possible and, thus, led to the complete withdrawal of external military. The civil war was declared over in 2002, and UNAMSIL withdrew in 2005.

Despite the major success, UNAMSIL and the UK-led security sector reform did not lead to a state monopoly on small-scale violence regulation. This outcome was caused by Sierra Leone's weak state legacies. Prior to both intervention and civil war, Sierra Leone never had a strong central state. Outside of larger cities, the chiefdoms were the major regulator of smallscale violence as they provided people with customary rules and enforcement mechanisms. Thus, these self-help communities outlasted the crises of the 1990s. The statebuilding intervention created government capacities in the form of formal institutions and a competent police force, but the chiefs could capture the statebuilding process early on. As a result, Sierra Leone today is a parastate in which small-scale violence is regulated both by state institutions and by self-help communities.

Before testing the proposed causal mechanisms, it is necessary to deal with major alternative explanations. The end of the civil war in Sierra Leone has so far been explained by variations of two arguments. First, in the common narrative on UNAMSIL and the war in Sierra Leone, the British intervention led to an instant defeat of the RUF (Bah 2012: 106-107). In this explanation, it was the determined and overwhelming military commitment of the UK that left no choice for the rebels but to surrender their arms. A closer look at the empirics reveals that there is little evidence for this interpretation. British forces intervened but were not part of many military engagements with the RUF. Furthermore, the UK withdrew most of its troops within few weeks (Olonisakin 2008: 63-64). The RUF was not completely defeated until over a year after the major military intervention began in May 2000. While Britain certainly played a crucial role in providing support for UNAMSIL and training Sierra Leonean security forces, its direct contribution to defeating the RUF was marginal. Lastly, it is not clear why UK should have 
succeeded easily in Sierra Leone and only shortly afterwards would fail in both Afghanistan and Iraq.

The second explanation that has been provided by several authors is that of the weakness of the RUF as a rebel group. In this line of argument, the RUF was simply a very poorly organized armed group and it took little external pressure to make it collapse. Its weakness is seen as a combination of bad leadership, a lack of legitimacy (Gberie 2005: 11-16) and poor supply networks (Hazen 2013: 73-75). While all of these points might be valid to a certain extent, they have little explanatory value. The RUF shares many of these features with other armed groups around the globe. More importantly, however, the Sierra Leonean rebel group was able to fight a civil war for eleven years. Their opponent was not just a weak government, but they also managed to resist ECOMOG with up to 15,000 troops as well as the strong PMC Executive Outcomes. Furthermore, the group was able to resist UN forces for another 2-3 years. Like all rebel groups, the RUF suffered military defeats, but it was always capable of recovering and resuming the war. The organization was institutionalized well enough to compensate for the absence of its charismatic leader, Foday Sankoh, from 1997 on. Because of the RUF's resilience, the international community hesitated to intervene and feared that Sierra Leone could become the next Somalia. All this indicates that the RUF was not a particularly weak group and, thus, its demise must have other reasons.

At the level of regulating small-scale violence is Sierra Leone, the intervention has failed to create a state monopoly. While there is a general consensus on the strength and autonomy of the chiefdoms, there have been few attempts to explain the monopolization failure. Instead, several authors have focused on the peacebuilding aspect of intervention. They criticize the illiberal character of chieftaincy, arguing that the re-establishment of the institution has recreated the causes of war (Acemoğlu et al. 2013; Hanlon 2005; Jackson 2005). In general, it is plausible that the exclusionary practices of the chieftaincy system have contributed to the slide towards civil war in the 1990s. As the case study will show, the strength of the post-war chieftaincy has several negative effects for statebuilding (like social exclusion or a lack of tax revenue). However, there are three aspects that should be considered when criticizing the interveners for return of chiefs. First, as this chapter will show, the alliance between the national elite and the chiefs preceded intervention. When the statebuilding mission began, the local elites were already in a powerful position vis-à-vis the central government. Second, as the theory chapter has argued, 
confronting self-help communities is very likely to lead to armed resistance. Despite external capacity-building, it is doubtful whether the central government would have been strong enough to risk such a strategy. Third, not every para state is the same. Under Stevens, the Sierra Leonean polity was highly centralized and chiefs had strong incentives to ignore their constituencies in favor of pleasing the central government. In contrast, the institutional set-up of post-war Sierra Leone has become much more inclusive as the central government is elected and local councils have been established. Chiefs increasingly have to compete with these democratic institutions. Overall, the accommodative strategy of the Kabbah administration might have undermined liberal statebuilding but was perhaps the most promising approach towards peacebuilding.

Statebuilding always occurs in the context of long-term state formation processes. Thus, before presenting the analysis, the next sub-chapter will set out the context by briefly describing the history of state formation in Sierra Leone, the main developments of the civil war and the regional political setting. Thereafter, it will analyze the mechanisms that produced the outcomes in monopoly scope and depth.

\subsection{State Formation and Civil War in Sierra Leone}

The effects of the UN statebuilding intervention in Sierra Leone cannot be properly understood without a basic idea about the historical context. State formation in West Africa is closely intertwined with colonialism and imperialism, as France and the United Kingdom have colonized the area for several centuries. The legacies of British colonization have affected state formation after independence, as Sierra Leonean government's struggled for about thirty years to create a stable state. In 1991, the struggle had been lost and a civil war began that destroyed the state and

turned Sierra Leone into one of the poorest countries in the world. This chapter discusses the origins of the Sierra Leonean state, its post-independence era and its eventual drift into civil war. 


\section{State Formation}

\section{Colonial Rule}

The history of modern day Sierra Leone began in 1787 when the 'St. George's Bay Company' with 400 'black poor' from London founded a settlement called 'Province of Freedom' in the region. This first settlement did not survive, however, and was followed by the Sierra Leone Company in 1792. 1,100 settlers founded Freetown, Sierra Leone's current capital. However, the company controlled the settlers' access to land, which led to revolts. The Sierra Leone Company was replaced by the African Institution after slavery was abolished in England in 1807. While these settlements were far from constituting a nation state in the modern sense, they laid the foundation for the state formation in the following two centuries. The early settlement did not extent much beyond the borders of Freetown and, hence, there was little interference with the indigenous Mende and Temne population. Within the Mano River region, many 'indigenous' people had only arrived there at the time of colonization, and the overall social landscape had been in flux even before the colonization of the coast had begun (Gerdes 2013b: 15-16). Compared to both Bosnia-Herzegovina and Afghanistan, Sierra Leone experienced very little endogenous state formation, and the process itself began historically late.

By 1896, the UK began to expand its territory and declared the hinterland to be part of its protectorate. Under British rule, Sierra Leone did not have an army in the modern sense. Instead, the British had created the so-called Sierra Leone Frontier Force (SLFF) in the 1890s to strengthen their grip on the hinterlands. However, these areas were ruled by local chiefs in these areas rebelled against British claims to taxation in the so-called Hut Tax War (Acemoğlu et al. 2013: 9-10). The SLFF had been re-named Sierra Leone Battalion in 1901, and the British Empire integrated the battalion into a regional West African Frontier Force. During the Second World War, the SLB was expanded to regiment size and its strength remained about the same well into the era of independence. Under British rule, the military's two major goals were to

maintain the internal colonial order and to defend the colony against other colonial powers (Rashid 2009: 93). Overall, Sierra Leone had little state infrastructure, had no national army, and was built upon a system of indirect rule up to its independence. 


\section{Independent State}

In 1961, Sierra Leone became an independent state. As was the case with many (if not most) former colonies, the colonial structures had a great impact on the shape of the state. Infrastructure had been built for the sole purpose of mining diamonds or planting cash crops, and exporting them overseas (Peters and Richards 2011: 378-380). Thus, there was a stark divide between urban Freetown and the rural hinterland. In rural areas there was little public infrastructure and the state was mostly absent form people's lives. The state was confined mostly to the tax collections chiefs had to conduct for the central government.

On becoming a sovereign state, Sierra Leone had to take care of its own defense policies for the first time. However, the government was reluctant to transform the colonial army ${ }^{23}$ into a proper national army. The slow transformation process, combined with an increased politicization of officers, resulted in several coups during the 1960s. After one term under the Sierra Leone People's Party (SLPP), the second free elections were won by Siaka Stevens and his All People's Congress (APC). Once he became President, the political situation was drastically de-stabilized by three consecutive coups in 1967/68 (Rashid 2009: 93-94). At the end of this period, Stevens was re-instated as President. Stevens was to become one of the key figures of Sierra Leone's post-independence statebuilding effort. Under his leadership Sierra Leone slowly transitioned into authoritarian rule, and this process was finalized by the transformation of the APC into the official state party. In 1985, Stevens handed over his Presidency to the head of the Armed Forces, Joseph Saidu Momoh, while staying chairman of the APC (Olonisakin 2008: 10-11).

Stevens' approach to building security forces was similar to that of many rulers of weak post-colonial states (Migdal 1988: 208-213). Under the impression of further coup attempts in the 1970s and 1980s, Stevens concluded that a strong army would be a threat to political stability. His regime made several institutional choices that paved the way for the future weakness of the armed forces (Rashid 2009: 94). The two major goals were to make the army leadership loyal and to weaken the military's capabilities. Loyalty was guaranteed through a patrimonial recruitment and payment system in which officers were promoted on the grounds of political allegiances. By

${ }^{23}$ At this point named West African Royal Regiment of Sierra Leone (Rashid 2009: 93). 
transforming Sierra Leone into a one-party state, Stevens could also utilize membership in the APC as a way to bind military leadership to his personal rule (Rashid 2009: 94). Additionally to these measures, the personnel strength was decreased and the armed forces were split. With international help Stevens built the Internal Security Unit (ISU), which was meant to act as a Praetorian Guard of the one party state. Its members were recruited on the basis of loyalty to the regime. Despite this recruitment procedure, Stevens took his divide and conquer tactics to the extreme by dividing the ISU into two separate units. One unit was trained by the British and Israelis, while the other unit was trained by the Cubans. However, the split led to internal tensions. Stevens eventually decided to merge the ISU parts into one coherent organization called Special Security Division (SSD) in 1979 (Krogstad 2012: 274). Due to all of these policies aiming at weakening the armed forces, the army consisted of no more than 3,000 soldiers at the beginning of the civil war in 1991 (Gberie 2005: 60).

At the eve of the civil war, Sierra Leone was a weak state that exercised little control outside the main cities. Within the short period between independence and civil war, the small country had not succeeded in overcoming the colonial design of its state institutions. Political elites competed for wealth and did little to strengthen the state's capabilities. Given the two-tier structure of its weak armed forces, the monopoly on large-scale violence was extremely fragile. The government oversaw a fragmented security sector consisting of the SLPF, the SLA, and the SSD. Against the backdrop of an economic crisis that started in the mid-1980s, there had been growing dissatisfaction with the one party system (Keen 2005: 25-32). Stevens successor Momoh started a process of political opening in the early 1990s, but these policies came too late to prevent armed conflict.

\section{Civil War and Intervention}

In March 1991, the government's claim to a monopoly on violence collapsed when the Revolutionary United Front (RUF) started its campaign in eastern Sierra Leone (Hazen 2013: 7677). The rebels' origins can be traced back into the 1980s. The likely reason for the rebellion can be found in the patrimonial structures formed by the APC one-party-rule. As long as the economy of Sierra Leone grew strongly, the state could pay the neopatrimonial network as well as food subsidies and public services. However, the economic downturn of the 1980s made the 
neopatrimonial political system more exclusionary. While Momoh cut public spending, he kept paying political elites for their loyalty (Keen 2005: 25-32). In the rural areas, the chiefdom system with its strong regulation of land ownership and agriculture made it difficult for young man to become economically independent members of society (Peters and Richards 2011: 379380). As Richards (1996: 161) argues, "[...] the war in Sierra Leone is best understood as a drama of social exclusion. The rebel leaders are energetic, determined people who feel strongly about being excluded from the networks of patrimonial support under the APC one-party regime". Hence, at the end of the 1980s, disgruntled Sierra Leonean students living in exile in Liberia, started to form an oppositional organization. These developments eventually led to the formation of the RUF.

The RUF was led by what could be considered a charismatic leader, Foday Sankoh. When the rebels started the war, they expected a quick victory and thus were ill-prepared to fund a sustained guerilla war. In the first years, the group relied on looting, weapons it captured from the SLA and direct support by Charles Taylor (Hazen 2013: 79-80). Only gradually did the organization shift its funding towards diamond smuggling. In 1995, it gained full access to important diamond mines for the first time (Hazen 2013: 94-95). It sold the diamonds from Sierra Leone to Liberian or Burkinabe traders who would then sell these diamonds on the world market. The RUF gained further strength through equipment captured after the 1997 coup, and further diamond mines captured in 1998 (Hazen 2013: 80). In general, "[the] RUF shared the same suppliers and supply routes as Charles Taylor's NPFL. Arms purchases were arranged from Eastern Europe by Libya, shipped to, and then through, Burkina Faso, Côte d'Ivoire and Liberia before reaching the RUF" (Holtom 2007: 7-8).

When the RUF started its campaign against the government of Sierra Leone in March 1991, it was not taken seriously by political elites. At the time when the civil war started, the government controlled only a small army of about 2,000 - 3,000 soldiers (Gberie 2005: 60). Once the threat to the regime became more obvious, the Momoh administration rapidly expanded the army to 6,100 soldiers. However, the army leadership became increasingly frustrated due to a perceived lack of political support for the armed forces (Kabia 2009: 109). This led to a military coup in April 1992, through which the 25-year old Captain Valentine Strasser became President of Sierra Leone (Gberie 2005: 67-69). The new National Provisional Ruling Council (NPRC) used diamond exports to pay for new military personnel. The army was quickly inflated from 
about 6,000 to 15,000 soldiers. This was almost a sevenfold increase compared to the size the armed forces had at the time the war began. Quick recruitment necessitated extremely low requirements for new recruits, and, therefore, many illiterates or criminals were enlisted. The command and control structures were outpaced by the military build-up (Hazen 2013: 93).

An important strategy of the government to regain control over the country was the deployment of local militias. Local hunters, in particular the 'Kamajors' of the south east, defended their local communities as early as 1992. The government made an effort to train and equip these militias, and several hundred of Kamajor fighters were deployed by the government in 1994 (Gberie 2005: 83-85). While they proved effective in keeping the RUF out of certain areas, they were also extremely hard to control for the government. In 1996, the local militias ${ }^{24}$ were brought under a nation-wide institution called 'Civil Defence Councils' (CDFs) and formally acknowledged by the government in 1998 (Wlodarczyk 2009: 203-204).

Another strategy to monopolize the use of force was to resort to mercenaries. When a greatly expanded army and local militias failed to deliver the expected results, the NPRC hired a private military contractor from South Africa in 1995. The company Executive Outcomes (EO) had two main tasks: On the one hand, it was supposed to directly confront the RUF with its heavy weaponry, especially with attack helicopters and EO's ability to take full advantage of modern combined arms. On the other hand, EO trained the armed forces and the Kamajors militias. Although the EO offensive forced the RUF to the negotiation table, it did not achieve a lasting defeat of the rebel organization. Later experiments with PMCs (notably Sandhurst) did not reach the efficacy of the deal with Executive Outcomes (Hazen 2013: 95-96).

Additionally to rebels, militias, PMCs and the Sierra Leonean government, regional states entered the conflict. Under the leadership of Nigeria, several ECOWAS member states deployed the ECOWAS Cease Fire Monitoring Group (ECOMOG) intervention force. The troops were sent directly from Liberia, where they supported the government against the NPFL uprising (SLTRC 2004: Vol. 3A, Ch. 3, 40). In response to the AFRC/RUF coup in 1997, ECOWAS increased its military presence and started offensive operations in order to regain control over Freetown. Although ECOMOG could keep the RUF from controlling the country, it never

\footnotetext{
${ }^{24}$ While the Kamajors were the largest hunter society, other groups, notably Donsos, Kapras, Gbethis, and Tamaboro, also participated (Wlodarzcyk 2009: 203-204).
} 
succeeded in re-establishing a monopoly on violence. ECOWAS, and Nigeria in particular, increased their troop levels step-wise to 13,000 soldiers in 1999 (Olonisakin 2008: 41-42). Overall, the ECOMOG intervention can hardly be described as a state-building mission, since it almost exclusively entailed fighting the RUF.

The control over government changed several times during the conflict. While the war started under the one-party-state rule of the APC, President Momoh was replaced through a military coup in 1992. Under the name National Provisional Ruling Council (NPRC), the military regime drastically expanded the armed forces in order to defeat the RUF. After another coup (led by General Bio) in 1996, elections were held and the Sierra Leone People's Party (SLPP) won a majority. Ahmad Tejan Kabbah became the new President, but was ousted by yet another coup in in 1997. The new established Armed Forces Revolutionary Council (AFRC) created a powersharing agreement with the RUF, but this constellation was abolished by an ECOMOG intervention which reinstated Kabbah. At the time of the UNAMSIL intervention, the country was thus divided into the parts controlled by Kabbah and ECOMOG on the one side, and those controlled by the RUF and AFRC remnants on the other side (Gberie 2005: 94-95).

Similar to other interventions such as the one in Afghanistan, the intervention in Sierra Leone was initially very modest. It followed a logic of steady escalation from careful attempts to monitor a peace agreement to a 17,500 troops-strong mission that aimed at transforming a whole society. When the UN began to deploy peacekeepers to Sierra Leone, it did so against the backdrop of an ongoing intervention by the regional ECOWAS group. Nigeria, Ghana and Guinea had deployed about 13,000 troops under the label of ECOMOG (Olonisakin 2008: 4142). This force supported the Sierra Leonean government in its fight against the RUF and, later, against parts of the armed forces. However, it was rather a plain combat mission did not seriously engage in building state institutions.

In July 1998, the UN dispatched a group of 30 military observers (UNOMSIL) to Sierra Leone as a reaction to the AFRC coup and the subsequent re-instatement of the Kabbah regime through ECOMOG in March 1998 (Olonisakin 2008: 24-25). The situation is well described by Olonisakin (2008: 25) who writes that "[..] in Sierra Leone, the UN had now joined the interesting mix of actors on the ground, but it was watching from the sidelines as regional troops, remnants of the Sierra Leone Army, and civil militias battled it out with the rebel alliance - RUF 
and AFRC fighters - in different locations in the hinterland". The international community was caught off guard by a major RUF offensive on the capital Freetown in January 1999, which left over 7,000 soldiers and civilians dead (HRW 1999: IV). Only the counter-offensive by Nigerian forces prevented the RUF from 'capturing' a state in which an UN observer mission was taking place. The resulting stalemate led to renewed negotiations and, eventually, to the conclusion of the Lomé Peace Agreement which contained far-reaching concessions to the RUF (Hazen 2013: 96-97).

Compared to other peace agreements brokered by the UN, the Lomé Accord was highly inclusive. It envisioned that theoretically all former RUF rebels, CDF fighters and army personnel were allowed to join the newly established Republic of Sierra Leone Armed Forces (RSLAF) after a basic screening procedure which only focused on criminal record but excluded human rights violations (Nilsson and Kovacs 2013: 4-5). This high degree of inclusivity was arguably driven less by the idea that the rebels have legitimate political goals, but was rather a concession to the military strength of the RUF. However, this power constellation meant that the RUF had little incentive to actually disarm, which in turn created a security environment in which the CDFs would also refuse their participation in DDR.

When the UN finally transformed its mission into a liberal statebuilding itnervention, there was little left of the Sierra Leonean state apparatus. The government did not have the organizational capacities to control the country, and it also lacked the political control over the armed forces. The SLA was widely discredited due to its inability to stop the insurgency and its later collaboration with the RUF. The vastly expanded army could neither be controlled nor was it properly paid and supplied (Rashid 2013: 98). This created strong incentives for soldiers to steal from the civilian population or work for the rebels at night. Among the population, these soldiers were also called 'sobels' (soldier at day, rebel at night). The police was seen as corrupt and more as a threat than a provider of public order. Furthermore, its area of operation was mostly confined to Freetown (Albrecht and Jackson 2009: 33-35).

To sum up, Sierra Leone had a very short history of state formation that did not lead to a strong central government. The coercive apparatus was then destroyed by the war of the 1990s, which also led to a drastic diffusion of the means of violence to rebels, militias and other private 
actors. By the late 1990s, the country was economically and politically devastated. In short, Sierra Leone was unlikely to become a statebuilding success.

\subsection{Statebuilding Intervention and Large-Scale Violence Regulation}

The statebuilding intervention in Sierra Leone lasted only about five years (2000-2005). Nevertheless, the interveners succeeded in ending the civil war, disarmed non-state armed groups, built a sustainable army and created a democratic institutional framework that stabilized the monopoly on large-scale violence. As pointed out in the last section, this success occurred despite the fact that Sierra Leone displayed many unfavorable conditions. The argument of this section is that the regional cooperation mechanism laid out in chapter three can explain the puzzling outcome of UNAMSIL. Before engaging with the causal mechanism, I provide a brief overview over the statebuilding intervention's design.

The United Nations Mission in Sierra Leone (UNAMSIL) was created in October 1999 as part of the Lomé Peace Agreement. Initially mandated with a troop limit of 6,000, this number was quickly tripled to 17,500 by March 2001 (UNSC 1999b: 3 ; 2001c: 1). Among other issues, UNAMSIL's initial mandate was to help in the conduct of democratic elections, and to foster the implementation of the peace treaty which already included the (re-)establishment of a monopoly on violence. However, the mission only received a robust chapter VII mandate in February 2000, thereby enabling it to actively monopolize the means of large-scale violence (UNSC 2000d: 3 ). The DDR process was delineated in Art. XVI of the Lomé Peace Accord in 1999 (UNSC 1999a: 20), and the restructuring of the Sierra Leone Armed Forces was delineated in Art. XVII of the Lomé Peace Accord in 1999 (UNSC 1999a: 20-21). UNAMSIL's tasks were summarized by the UN Secretary General as "[...] to assist the efforts of the Government of Sierra Leone to extend its authority, restore law and order and stabilize the situation progressively throughout the entire country, and to assist in the promotion of a political process which should lead to a renewed disarmament, demobilization and reintegration programme and the holding, in due course, of free and fair elections" (UNSC 2001a: §58). Thus, UNAMSIL can clearly be classified as a liberal statebuilding intervention. 
At the beginning of the UN intervention, ECOMOG still played a crucial role. It protected the UN force against the RUF while the international intervention slowly grew and took shape. At the time UNAMSIL was established, ECOMOG had about 13,000 troops deployed in Sierra Leone (Olonisakin 2008: 41-42). UNAMSIL was designed planned to be complementary to ECOMOG. The idea was to share the burden of warfare by splitting the military tasks between Nigeria and the UN contingent. However, due to mounting domestic pressure on the newly elected Nigerian government to end the decade-long intervention in Sierra Leone, Nigeria announced the end of ECOMOG in December 1999 (Kabia 2009: 126-127). Against this backdrop, the UNSC decided to strengthen UNAMSIL's mandate by increasing the envisioned troop level to 11,000 (Olonisakin 2008: 48). However, when all 13,000 Nigerian ECOMOG soldiers had left the country by May 2000, UNAMSIL had reached a troop level of only 9,000 soldiers. Nevertheless, Nigeria (and other regional states) continued to contribute troops to UNAMSIL. In mid-May 2000, UNAMSIL had a strength of 9,178, of which were 3,217 'rehatted' Nigerians, 776 Ghanaians and 776 Guineans (UNSC 2000b: 18).

For the RUF, the ECOMOG withdrawal meant a significant change in the balance of power. Up until May 2000, the RUF had tried to circumvent disarmament mostly in a passive fashion. Once ECOMOG was dissolved and troops had left the country, the RUF changed its tactics from passive denial to offensive actions against the UN. At the beginning of May 2000, RUF fighters attacked a central pillar of the UNAMSIL plan: The DDR camps where fighters were meant to be disarmed and handed over their reintegration packages. Rebels attacked the DDR camps in Magburaka and Makeni (Olonisakin 2008: 55). Days later, the RUF managed to publicly embarrass UNAMSIL by taking about 500 Zambian UN soldiers as hostages (Kabia 2009: 127). Rumors emerged that the RUF planned to attack the capital, Freetown. The events of May 2000 quickly turned into one of the biggest crises for UN peacebuilding. RUF forces controlled about $2 / 3$ of the territory, and the kidnapping of large numbers of peacekeepers as well as the large-scale theft of UN weapons by rebels completely undermined the public confidence in UNAMSIL (Olonisakin 2008: 58-60).

In reaction to the May 2000 crisis, about 1,200 British troops intervened in order to stabilize UNAMSIL and defend Freetown (Olonisakin 2008: 63-64). In the face of the RUF offensive, the interveners adjusted its goals for SSR. Instead of disarming the Sierra Leonean Army the decision was made to simply reform it, thereby creating a greater institutional 
continuity between the old and the new armed forces (Nilsson and Kovacs 2013: 6). Despite this, the remnants of the SLA did not offer much of an institutional foundation. The term security sector reform is somewhat misleading in cases where the security sector had virtually collapsed. SSR in Sierra Leone had to deal with the fact that there was not much left of the security forces, and therefore it "[..] occurred at a very basic level of state-building and peacemaking-cumbuilding in support of one of the primary markers of sovereignty: the monopoly of the means of violence" (Albrecht 2010: 19).

In sum, by early 2000 UNAMSIL had transformed into a liberal statebuilding intervention that aimed for the establishment of a state monopoly on large-scale violence. However, despite a formal peace agreement the RUF chose to resist these monopolization efforts.

\section{The Regional Cooperation Mechanism}

The statebuilding intervention in Sierra Leone had to create a monopoly on large-scale violence against the backdrop of long-term conflict, state failure, poverty, ethnic heterogeneity, and armed resistance by the RUF. Nevertheless, UNAMSIL succeeded to build a sustainable monopoly on warfare and could withdraw its troops from Sierra Leone after less than six years. This section applies the regional cooperation mechanism to the case of Sierra Leone, arguing that the surprising outcome can only be explained by taking the wider regional context into account.

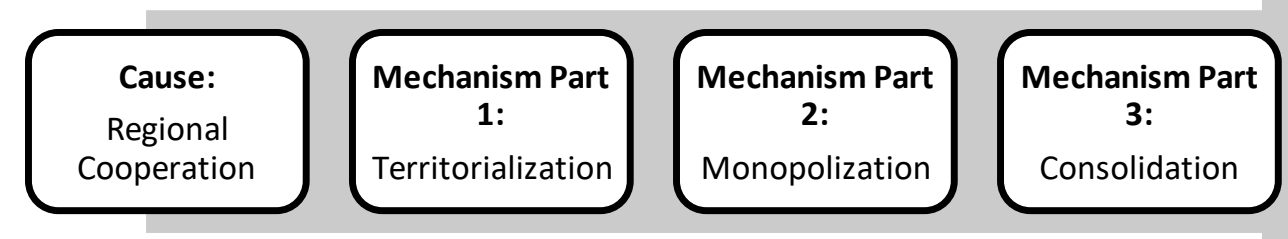

Outcome: State Monopoly on Large-Scale Violence

\section{Figure 16: Regional Cooperation Mechanism.}


In the case of Sierra Leone, the statebuilding intervention was supported by the most powerful regional actors, Nigeria and Ghana. Furthermore, neighboring Guinea supported the UNAMSIL as well as several actors in Liberia. This regional cooperation triggered the regional cooperation mechanism:

(1) Territorialization: As the statebuilding intervention expanded in Sierra Leone, ECOWAS and the UN increased the pressure on the Liberian Taylor regime, thereby weakening the RUF's main ally. At the same time, the RUF's access to the Liberian border region was cut off by Guinean support for Liberian rebels. Eventually, the RUF lost its access to transnational markets and sanctuaries.

(2) Monopolization: The ability of the RUF to challenge the statebuilding intervention was dependent on its (tacit and active) support from Liberia (and Charles Taylor in particular). Without its supply networks in Liberia, the RUF could not recover from military defeats and eventually accepted the UN'S DDR scheme.

(3) Consolidation: The statebuilding intervention supported the government in reforming its security sector and building a professional, sustainably sized army. As a consequence, the Republic of Sierra Leone Armed Forces are comparably small and their political control has been greatly increased.

The result is a state monopoly on large-scale violence. The UN could withdraw its forces in 2005 , and since then, Sierra Leone has been stable and democratic. The following sections will processtrace the case in detail, starting with the regional cooperation that caused the successful monopolization of the means of warfare.

\section{Cause: Regional Cooperation}

The statebuilding intervention in Sierra Leone enjoyed strong regional support. It was supported by the major powers of West Africa as well as the neighboring Guinea. In Liberia, political elites were split: While the Taylor administration supported the RUF, LURD was an ally of Guinea.

Sierra Leone is situated in Western Africa, a poor and instable region. Consisting of about two dozen rather small countries, Nigeria is by far the largest nation and dominates regional politics. With a population of about 170 million, Nigeria is more than six times as big as the 
second country to the region (Ghana). Its dominance renders West Africa a unipolar regional system. The region has been the stage for several civil wars since the end of the Cold War. Major armed conflicts occurred in Guinea Guinea-Bissau, Ivory Coast Liberia and Sierra Leone (Gleditsch et al. 2002) ${ }^{25}$ Additionally, there are recurring crises due to coups or electoral disputes in Guinea, Guinea-Bissau Ivory Coast, Niger, and Nigeria (Powell and Thyne 2011). Many of the civil wars were strongly inter-related. Rebels used territories of neighboring states as sanctuaries or were materially supported by neighboring states. In addition, arms, money or contraband crossed the porous borders and enabled rebels and governments to fight on. In terms of economic development, the region is generally very poor but also shows great disparities across states as well as within states. The GDP per capita of Liberia (\$324), the region's poorest country, is only a tenth of that of the richest one (Cape Verde, \$3,345) (WorldBank 2013b). Despite instability and poverty, West Africa has seen some success in democratization efforts during the $2000 \mathrm{~s}^{26}$. The key regional states for Sierra Leone are its direct neighbors, Guinea and Liberia, and the most powerful state in the region, Nigeria.

\footnotetext{
${ }^{25}$ Data set last updated in 2009.

${ }^{26}$ For example, on the 21-point PolityIV scale (-10 full autocracy, +10 full democracy) for 2010 , nine out of sixteen ECOWAS states score +5 or higher. The most autocratic states are Gambia (-5), Mauretania and Togo (both -2) (Marshall et al. 2013).
} 


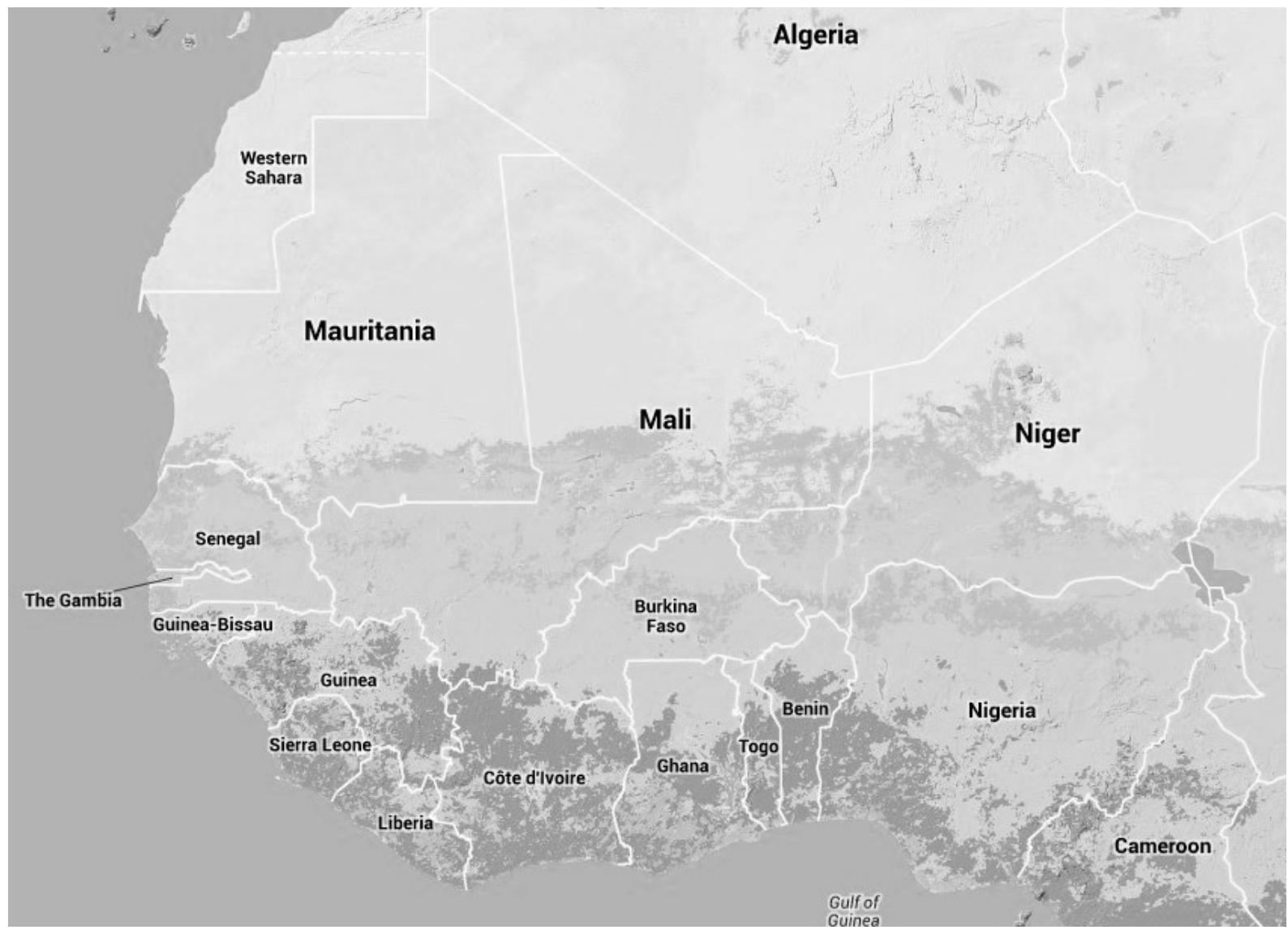

Figure 17: Map of Sierra Leone and the wider West African region (Google 2014).

\section{Guinea}

Guinea is a small country of about ten million inhabitants. It surrounds all of Sierra Leone except for the Liberian border and the sea. Its population is one of the poorest in the world and the UN counts it as a least developed country. Guinea was a French colony and declared its independence in 1958. It has been strongly shaped by its long-term President, Lansana Conté, who gained power through a military coup and would stay in office until his death in December 2008 (BTI 2014b: 3-4). The civil war in Sierra Leone as well as the UNAMSIL intervention took place during Conté's reign.

Guinea's military capacities are small in international comparison. Nevertheless, the government has a functioning military of about 10,000 soldiers at its command. Guinea's armed forces have long been politicized by the ruling elites and are thus difficult to control for any elected government. During the last two decades, the government used the army several times to 
crush protest movements. Among other atrocities, this resulted in the killing of over 150 people in September 2009. The state lacks a coherent national strategy, so that it is difficult for outsiders to understand the priorities of Guinea (ICG 2010b: 23). However, it is possible to derive some of these security priorities from Guinea's recent history of state formation. Next to defending the country against other states, its national interest can broadly be described in terms of regional stability and a strengthening of friendly governments in neighboring states. Consequently, Guinea's main interest in Sierra Leone's civil war was to restore government control over the country and prevent the RUF rebellion from spilling over to its own fragile polity. It thus contributed troops to ECOMOG during the 1990s.

\section{Liberia}

Liberia is the other direct neighbor. Founded by former US slaves and independent since 1847, it is one of the oldest sovereign states in Africa. Originally conceptualized as a land in which black people could finally live free and in self-determination, tensions between the settlers and the native inhabitants of Liberia quickly emerged (Gerdes 2013b: 16-19). As in many colonial African states, early Liberian state-building was shaped by conflict between indigenous groups in the hinterland and the urban (or colonial) elites in coastal regions that had access to the world market. For most of its history, Liberian politics were dominated by the 'Americo-Liberian' elite. This changed with a coup in 1980, in which allegedly pro-indigenous forces came to power (Gerdes 2013b: 39-40).

Liberia descended into civil war in 1989, when the NPFL under Charles Taylor started a guerilla war against the Monrovia government. Taylor became the dominant figure of Liberian politics both as a rebel leader and, from 1997 on, as its President (ICG 2002a: 1-2). Even before he became President, he supported the RUF. Hazen (2013: 87) argues that "Taylor supported the RUF to punish Sierra Leone for providing a base for the ECOMOG operations in Liberia and to relieve the military pressure on his own rebellion in Liberia, not to support the RUF's political aims". Taylor's regime became the major political and economic patron of the RUF, and he used it to further his geopolitical interests in the region (Hazen 2013: 86-87). Taylor (at times supported by Burkina Faso) pursued an aggressive, revisionist foreign policy and supported rebel groups in Guinea, Côte d'Ivoire and Sierra Leone (Gerdes 2013a: 161-165). However, the 
emerging rebel groups in Liberia, Liberians United for Reconciliation and Democracy (LURD) and Movement for Democracy in Liberia (MODEL) opposed not only Taylor, but also accepted the regional status quo and cooperated with Guinea, Côte d'Ivoire and the ECOWAS/UN intervention later on.

\section{Nigeria}

Nigeria, the regional hegemon, is plagued by the same problems as its smaller neighbor states. Although the country has seen economic growth during the last decades, not least due to its oil revenues, large parts of its huge population are still very poor. During the time of the Sierra Leonean civil war, Nigeria faced great regime instability. Following a period of military dictatorship, elections were held in 1993 but the new government was quickly overturned by a military coup. In 1999, a new constitution and elections eventually resulted in a period of prolonged democratization, although many democratic deficits remain (BTI 2014d: 3-4). Nigeria's foreign policy is marked by a contrast between its relative position in the region and its absolute strength. On the one hand, Nigeria is by far the strongest state in the region in terms of demography, economy and military, and it has taken up a leadership position in ECOWAS. Since the 1980s, it defined its national interest in terms of 'concentric circles' around its territory. Thus, Nigeria is openly seeking a hegemonic role in the region (Alli 2012: 11-14). On the other hand, Nigeria is itself a fragile state that struggles with internal violence (especially the Boko Haram insurgency) and often lacks the means to effectively project power across the region. Although Nigeria lacks a coherent national security strategy (Ibeanu and Momoh 2008) most Nigerian governments have seen regional integration as central to their national security (Kabia 2009: 5960). During the 1990s, Nigeria sent troops to civil war afflicted countries in the region, especially to Liberia and Sierra Leone. These interventions were mostly aimed at stabilizing governments and reducing the risks of transnationally spreading conflict (ICG 2002a: 2). Moreover, Nigeria was credibly committed to restore democracy in Sierra Leone, even while it was governed itself by a military dictatorship at home (Olonisakin 2008: 30). 


\section{Regional Integration}

Western Africa displays a high degree of regional integration. The international organization through which this integration is fostered is the Economic Community of Western African States (ECOWAS). ECOWAS was founded in 1975 as an economic union, and its goal was to increase intra-regional economic trade by lowering barriers to trade. At the same time, one major impetus for increased regional integration was Nigeria's desire to deepen its ties with neighboring countries and, thereby, reduce French influence in West Africa. Due to its colonial history, West Africa is traditionally divided into Francophone and Anglophone countries. In the early postindependence years, France tried to keep up its influence over the region and, among other policies, supported the Biafra rebellion in Nigeria (Kabia 2009: 57-59). Hence, "[as] the country is literally surrounded by Francophone neighbours, Nigeria's post-civil war foreign policy was geared towards strengthening economic and political ties with its neighbours so as to prevent them supporting any future secessionists" (Kabia 2009: 59). In 1978, ECOWAS was expanded by including a non-aggression treaty. While this was the first time that security-relevant aspects entered the treaty, it did not exceed the scope of the general international norm of non-aggression that all UN members are supposed to subscribe to (Kabia 2009: 66-67). However, the experience of wide-spread civil wars and political instability during the 1990s led to a transformation of ECOWAS into a security community. The ECOWAS treaties now include a commitment to interventionism and good governance (Rashid 2013: 6-8). Thereby, ECOWAS exceeds the scope of the vast majority of regional organizations. However, economic integration is still lagging behind and the member states have not achieved what was aimed for in the ECOWAS agreements. Nevertheless, the union has become a key player in regional security.

To sum up, Western Africa is characterized by instability and poverty as well as strong regional integration. Key regional states shared the interest of the UN and the UK in building a liberal state in Sierra Leone. As the next section will show, the cooperative regional setting made it possible to deny the RUF access to its Liberian sanctuary during the statebuilding intervention. 


\section{Step One: Territorialization}

By mid-2000, UNAMSIL and the UK had committed themselves to a full-scale statebuilding intervention in Sierra Leone. Regional cooperation with UNAMSIL allowed for the territorialization of the conflict. Due to the pressure that the regional actors put on Liberia's Charles Taylor, it was possible to seal off the border and cut off the RUF from its access to transnational spaces.

Amid the deep crisis and the transformation of the UN mission in mid-May 2000, the UK decided to intervene in Sierra Leone. It had positioned forces at the coast and started a military operation with the initial goal of rescuing British citizens from Freetown. However, the operation developed a dynamic of its own. The British send 1,200 troops and secured the strategically important Lungi Airport (Olonisakin 2008: 63-64). This allowed UNAMSIL troops to shift their emphasis to the city and its surroundings. While the British intervention certainly signaled the rebels that the international community was determined to field more firepower, the UK did not bring much territory under control or directly engaged the RUF (Olonisakin 2008: 63-64). Instead, it was an operation that provided UNAMSIL with relief and a possibility to regain the initiative. The UN Security Council met in May and again in July, raising the troop level to about 12,500. Due to the rapidly growing size of the UN mission and the UK relief operations, UNAMSIL switched to a strategy of 'progressive deployment', i.e. it started offensive operations against the RUF. Throughout the summer of 2000, the UN expanded its presence throughout the territory of Sierra Leone and closer to the Liberian border (Olonisakin 2008: 93-94 ; UNSC 2000a: 4-5).

At the same time that the UN increased the military pressure on the RUF, Guinea started equipping LURD rebels that planned to oust Charles Taylor in Liberia. In July 2000, the Conté administration allowed LURD to attack Liberia from Guinean territory (ICG 2002a: 4). The LURD offensive hit the Liberian armed forces exactly in those western areas that are close to the border with Sierra Leone and hosted crucial supply lines of the RUF (Hazen 2013: 99-101). Taylor reacted by ordering parts of the RUF to attack Guinea in September 2000. Instead of pushing back LURD in the Sierra Leonean border region, Taylor convinced the RUF leadership to attack Guinea from western Sierra Leone in order to threaten Guinea's capital, Conakry. In addition to RUF forces, local dissidents were mobilized and the offensive showed initial success 
(ICG 2002a: 4-5). These gains convinced the government of Guinea to take the threat more seriously. The Conté administration acquired started a broad, conventional military offensive against the RUF and also supported CDFs in Sierra Leone. As a result, by January 2001 the RUF had been pushed out of Guinea (Gberie 2005: 172-173). Against the backdrop of the heavy fighting, there were fears that the RUF in Sierra Leone might re-mobilize in order to conduct attacks against Guinea. Thus, the governments of Sierra Leone and Guinea began to coordinate their efforts against the RUF (UNSC 2001a: 4).

By November 2000, the RUF resorted to its proven tactic of signing a peace agreement when under pressure. Yet despite the Abuja Agreement, which contained a clear commitment to DDR, the RUF still tried to keep UNAMSIL out of its zones of control (Olonisakin 2008: 101102). Nevertheless, the UN started deploying the first 1,800 troops in the border region of Liberia, Guinea and Sierra Leone in December 2000 (UNSC 2001a: 4-5). Simultaneously, Guinea increased its efforts to support LURD. This occurred without approval from the Kabbah administration which feared a backlash should Taylor win the fight against the rebel organization (ICG 2002a: 4). After receiving training and equipment from Guinea, Donso and Kamajor militias entered Liberian territory in mid-November 2000 in an effort to support the LURD offensive. This increased the military pressure on Liberia's armed forces further and left little room for Taylor to support the RUF in Sierra Leone. The fighting lasted throughout 2001, and in April 2002 LURD had established firm control over the border region with Sierra Leone (Hazen 2013: 130).

At the international level, the UN combined its military actions with an effort to stop the trade in Sierra Leonean diamonds, which were the main funding source of the RUF. Prior efforts to let ECOMOG impose an arms embargo against the RUF had been ineffective (Holtom 2007: 14-15). In July 2000, the UN Security Council passed resolution 1306 which banned the worldwide trade in diamonds from Sierra Leone. This was a crucial first step to disrupt the money inflow that enabled the RUF to conduct its war. However, this was not fully effective because many the diamonds were smuggled through neighboring countries and sold under false claims of origin (UNSC 2000c: 18-19). In December 2000, the UN provided its report on the diamond trading network in Western Africa. The report suggested that the RUF has made somewhere between 25 and 125 million dollars per year through selling diamonds (UNSC 2000c: 17). It singled out Liberia as the key trading route, from where diamonds were either sold on the 
world market or smuggled further to the Gambia (UNSC 2000c: 17-19). The report argued that "[..] there is sufficient evidence to prove that this trade cannot be conducted in Liberia without the permission and the involvement of government officials at the highest level" (UNSC 2000c: 19). This was a very important claim, because it showed that the RUF's supply network was not just the result of weak statehood and porous borders. Instead, Taylor enabled the RUF's war by granting it a trading route. After the report was published, the UN Security Council decided to impose a diamond export embargo on Liberia in March 2001. Since Liberia lacked a route through which to sell the diamonds on the world market, its diamond exports collapsed (UNSC 2001b: 76). Thus, by mid-2001, through the combined effect of LURD operations and the international diamond ban, the RUF could not rely on its Liberian network anymore.

It is important to point out that the territorialization of the conflict was not one-off event but part of a broader pattern of regional efforts to stabilize Sierra Leone and, eventually, Liberia. Between 2000 and 2003, while the Kabbah administration was trying to build and consolidate a monopoly on violence, LURD and MODEL conquered ever greater swaths of Liberian territory. In order to prevent a rebel victory and to build a stable, peaceful state in Liberia, ECOWAS deployed thousands of troops to Monrovia in September 2003. The force was transformed into UNMIL in October 2003. Thus, ECOWAS eventually supported those Liberian actors who accepted the territorial sovereignty of its neighbors. Consequently, cooperation between Sierra Leone and Liberia has steadily increased since the wars came to an end. Indicators of this cooperation are the re-opening of the common border (AFP 2007) in 2007 as well as the reactivation of the Mano River Union"27, a small sub-regional IO that "[..] aims to strengthen the capacity of Member States to integrate their economies and coordinate development programs in the areas of peace building [..]" (MRU 2014) in 2008.

Overall, in the short-term regional cooperation helped to cut off the RUF from supply routes and sanctuaries. In the long run, it fostered a regional system in which the sovereignty of Sierra Leone is respected and transnational insurgencies have become unlikely.

\footnotetext{
${ }^{27}$ The Mano River Union consists of Côte d'Ivoire, Guinea, Liberia, and Sierra Leone.
} 


\section{Step Two: Monopolization}

By mid-2001, the RUF could neither sell diamonds on the global market nor could it acquire resupplies for its fighters. As a consequence, the armed group lacked the organizational capacities to resist UNAMSIL's efforts to monopolize the means of large-scale violence. The RUF was disarmed during 2001 and UNAMSIL could expand its control over the whole territory of Sierra Leone. By 2002, the government and UNAMSIL exclusively controlled the means of large-scale violence.

Due to its loss of access to Liberian territory, the RUF's capacity to continue fighting declined and the leadership became willing to negotiate with the government and UNAMSIL (Olonisakin 2008: 103-104). Since the RUF had always negotiated when it was weak only to regroup and continue its war (Hazen 2013: 75), the process of monopolization had to combine political negotiations with sustained military pressure. Hence, UNAMSIL continued its troop buildup and sought to expand its territorial reach. On the political side, the UN was willing to reopen negotiations with the rebels. Half a year after they had agreed to the November 2000 Abuja Agreement, the RUF was weakened to such an extent that it approached UNAMSIL to for new talks. At a May 2001 meeting of the so-called Joint Committee, the UN, the government of Sierra Leone, the RUF and ECOWAS met again in Abuja (UNSC 2001d: 1-2). The resulting Abuja Agreement II can be seen as the first peace deal the RUF leadership honestly accepted, because in the following months its military units were incrementally disarmed. All sides of the treaty agreed on the so-called 'Kambia formula' (Olonisakin 2008: 103-104). In the case of the Kambia district, the RUF had agreed to let fighters who had fled from Guinea's offensive participate in the DDR program. In return, the local CDF militias had to disarm simultaneously. Furthermore, RSLAF units were deployed to the district to re-gain government control over the some of its border with Guinea (UNSC 2001d: 1-2).

Nevertheless, the monopolization process always retained its military component. Given Sierra Leone's recent history of broken peace treaties, military pressure had to be sustained in order to prevent the RUF from opting out of the DDR process. It took until November 2001 for UNAMSIL to finally meet its 17,500 troop level target. Of these, Ghana, Guinea and Nigeria still contributed almost 5,000 troops. Bangladesh and Pakistan were the other major troop contributors, with each having more than 4,000 soldiers deployed to Sierra Leone (UNSC 2001e: 
14). Since the RSLAF were still weak, the government as well as UNAMSIL relied to a great extent on the CDF militias to fight the RUF. In the eastern Kono district, CDF forces conquered large parts of the district and marched toward the capital Koido by May 2001. Facing defeat, the RUF let its local units surrender and they were subsequently disarmed simultaneously with the local CDFs (UNSC 2001d: 3). Throughout the year, the RUF tried to keep the mining areas under its control so that clashes with CDFs continued (UNSC 2001e: 2). Until late 2001, RUF forces were able to hold on to a few areas of the border region from where they supported Liberian forces fighting LURD. Against the backdrop of political pressure from Guinea, Kabbah deployed RSLAF troops to Kailahun and thereby secured the last swaths of the border region (ICG 2002a: 6). Thus, by early 2002 the state had regained control over almost all of the territory and, most importantly, controlled its borders. This combination of political and military measures proved highly effective in an environment where the RUF was unable to either escape the pressure or at least resupply its forces. Confronted with the possibility of being militarily defeated, the RUF chose to join the DDR process. During 2001 almost all former RUF combatants were disarmed, except for a minority that joined Taylor in his fight in Liberia. "By January 2002, 72,490 combatants, both RUF and CDF, had been disarmed and a total of 42,000 weapons and 1.2 million rounds of ammunition collected" (Gberie 2005: 171).

Overall, the territorialization of the conflict proved crucial to the monopolization of the means of large-scale violence by the international statebuilders. The RUF was able to resist a host of actors over a decade: The Sierra Leonean Army, the CDF militias, several powerful private military companies, ECOMOG and, for a certain period of time, the UN itself. Without the ongoing conflict, the statebuilding intervention could support the government in consolidating the hard-won monopoly on large-scale violence.

\section{Step Three: Consolidation}

The defeat of the RUF allowed the interveners to consolidate the monopoly on large-scale violence. Without ongoing conflict, the government and its external supporters could build a new army that was smaller in size, more professional and politically controlled. Democratic institutions were strengthened in order to regulate access to and control over the means of largescale violence. 
In order to understand the importance and difficulty of the consolidation phase, it is necessary to recall the state of the armed forces at the beginning of the statebuilding intervention. After the SLPP re-gained control over the government in 1998 with the help of ECOMOG, it was deprived of almost all means to govern. Due to the 1997 coup, the army was seen as unreliable and part of the army (i.e. the AFRC) had joined forces with the RUF. The rest of the armed forces was dissolved and the goal was to rebuild a more reliable army. In the short-term, the government's most potent means of coercion was its lose control over CDF militias (Kabia 2009: 133-134). However, the CDFs were too decentralized and now long-term alternative to a proper army. Hence, the 'security sector reform' turned into an effort to build a new security sector from scratch. ECOMOG, on which the government was heavily dependent, completely failed at conducting DDR or SSR in Sierra Leone (Kabia 2009: 131-133).

In 1999, the UK and the government considered re-building Sierra Leone as a state without an army. This option was discarded, not least because of the RUF's Freetown offensive and strong political pressure from ECOMOG. Hence, in December 1999, the decision was made to re-build the army (Albrecht and Jackson 2009: 22-23). During the next 2-3 years, the government would expand the new army rapidly from about two battalions in 1999 to about 12,000 at the end of the civil war (Albrecht and Jackson 2009: 23-24 ; Nilsson and Kovacs 2013: 7). While this was probably a necessity given the limited amount of troops deployed by UNAMSIL and the UK, it risked repeating the mistakes of the 1990s when a massive recruitment de-professionalized the army and led to two military coups (Rashid 2009: 95-96).

While DDR and SSR were already delineated in the Lomé Agreement in 1999 (UNSC 1999a: 20-21), the security sector reform did start only slowly. In mid-1999, the UK sent a small group of experts to assess the state of the security sector in Sierra Leone and advice the government. The administrative capacities of the government were so degraded that the MoD consisted of a few dozen of employees which mostly distributed resources to the CDFs and ECOMOG (Albrecht and Jackson 2009: 46). In June 2000, the UK intensified its support for SSR by creating its International Military Assistance Training Team (IMATT), which was tasked with oversight of the internal reform of the armed forces. While there was an overall professionalization of the armed forces, IMATT could not prevent the SLPP from recruiting a number of loyal individuals into leadership positions at the MoD (Nelson-Williams 2009: 124125). Nevertheless, "[by] 2001, the MoD was regarded as leading the way in public service 
reform, setting standards and providing a role model for other ministries in terms of running effectively" (Albrecht and Jackson 2009: 49).

During 2001, the accelerating retreat and dissolution of RUF forces allowed the government to deploy RSLAF troops across the country. For the first time since the start of the war, the army could be deployed to take control over cleared areas instead of being sent directly into an ongoing guerilla war. Starting in May 2001 with the Kambia district at the Western border to Guinea (UNSC 2001d: 1-2), the government took control over its territory in slow but consecutive steps. By the end of 2001, the army controlled "[...] key areas on the borders with Guinea and Liberia, including in the Kono, Koinadugu and Pujehun districts" (UNSC 2001e: 2). At the beginning of 2002, after Kabbah declared the end of the civil war, the Ministry of Defense was inaugurated. This was an important step in institutionalizing the monopoly on the use of force because the $\mathrm{MoD}$ is the administrative structure through which the government can control its armed forces. At the same time, the different branches of the military were bundled under a uniform structure and re-named to Republic of Sierra Leone Armed Forces (RSLAF). Active leadership of the SRR gradually shifted towards the Sierra Leonean government. For example, in 2003 the MoD published its first White Paper and outlined a clear strategic vision of the further reform process (Gbla 2006: 84-85).

Although the goal of SSR was to create a small, reliable and professional army, the Military Reintegration Program (MRP) first led to a further increase in the number of soldiers, while the inclusion of rebels and CDF members further decreased the RSLAF's coherence (Nilsson and Kovacs 2013: 6).

In Sierra Leone, all former ex-combatants who participated in the renewed disarmament and demobilization process were briefed on the existence of the MRP and given the option to seek entry into the armed forces. However, only a small minority of all ex-combatants, about 2,500, of which about two-thirds came from the RUF and the rest from the CDF, decided to do so. At this time, the size of the existing army - consisting of former SLA soldiers, some of whom had only been recruited after Kabbah's return to power in 1998, and former AFRC junta soldiers - was about 12,000. Following the implementation of the MRP, the RSLAF thus expanded to about 14,500. (Nilsson and Kovacs 2013: 7) 
Over the following years, the size of the armed forces was drastically reduced. From its peak of 14,500 troops in 2002, the army has been downsized to 8,500 troops in 2010, a reduction in personnel of about $40 \%$. With the downsizing process completed, the recruitment process has become very competitive. Without an ongoing conflict, recruitment and training can focus on professionalism instead of simply training 'trigger-pullers'. The government aims at recruiting its soldiers proportionally from all four major provinces in order to avoid ethnic imbalances (Nilsson and Kovacs 2013: 7-9). In terms of fiscal sustainability, Sierra Leone is a very poor country, and a decade after the war's end, the government budget still depends on external aid inflows. The statebuilding intervention and external aid have allowed the Sierra Leonean state to sustain armed forces without making cuts in other areas of the budget. Nevertheless the major downsizing of the armed forces has greatly reduced the government expenses for defense. Therefore, Sierra Leone was on a path to become financially independent in the foreseeable future ${ }^{28}$.

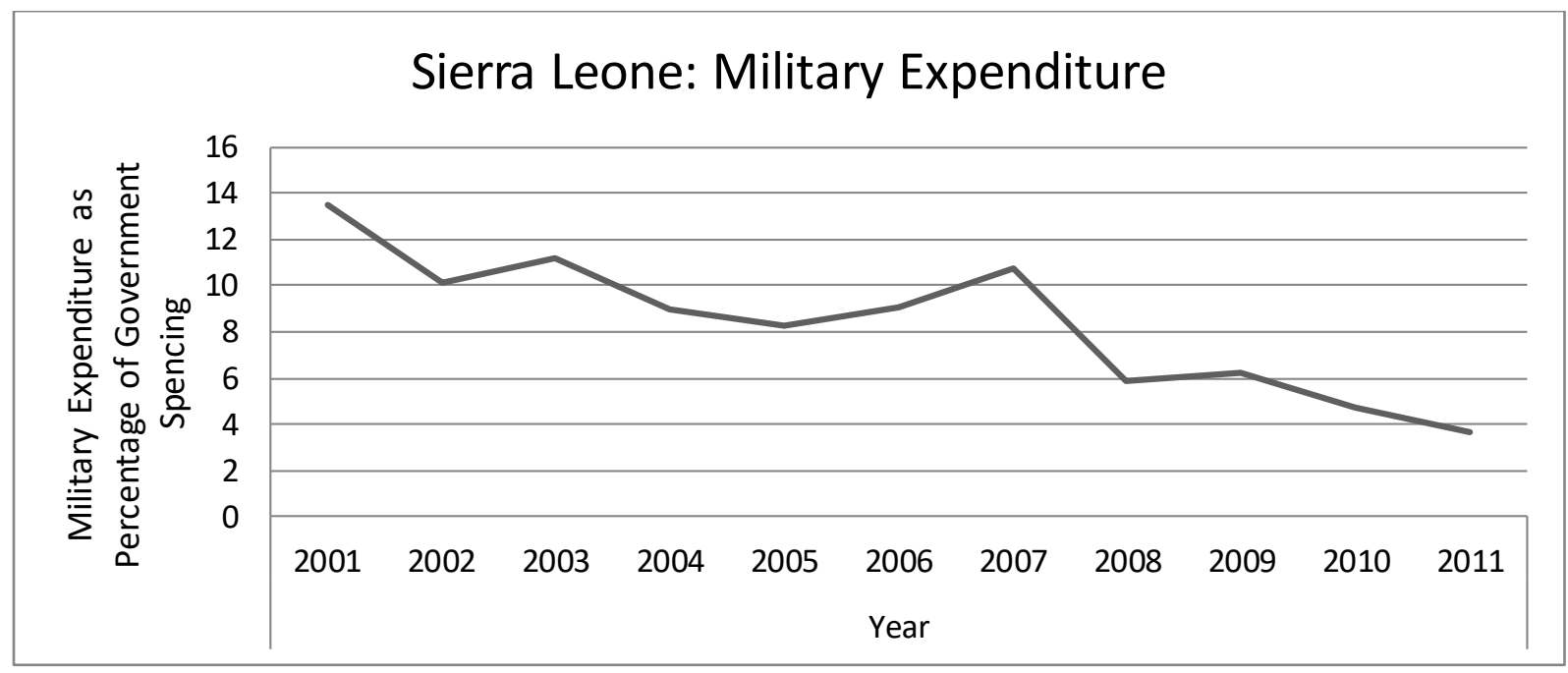

Figure 18: Military expenditures of the Si erra Leonean state (WorldBank 2014).

As World Bank data shows, the government in Freetown has managed to significantly reduce its defense spending as well as its dependence on development assistance.

\footnotetext{
${ }^{28}$ At the time of writing, a large Ebola epidemic in Western Africa poses a major challenge for the budgets as well as the political stability of all affected countries.
} 


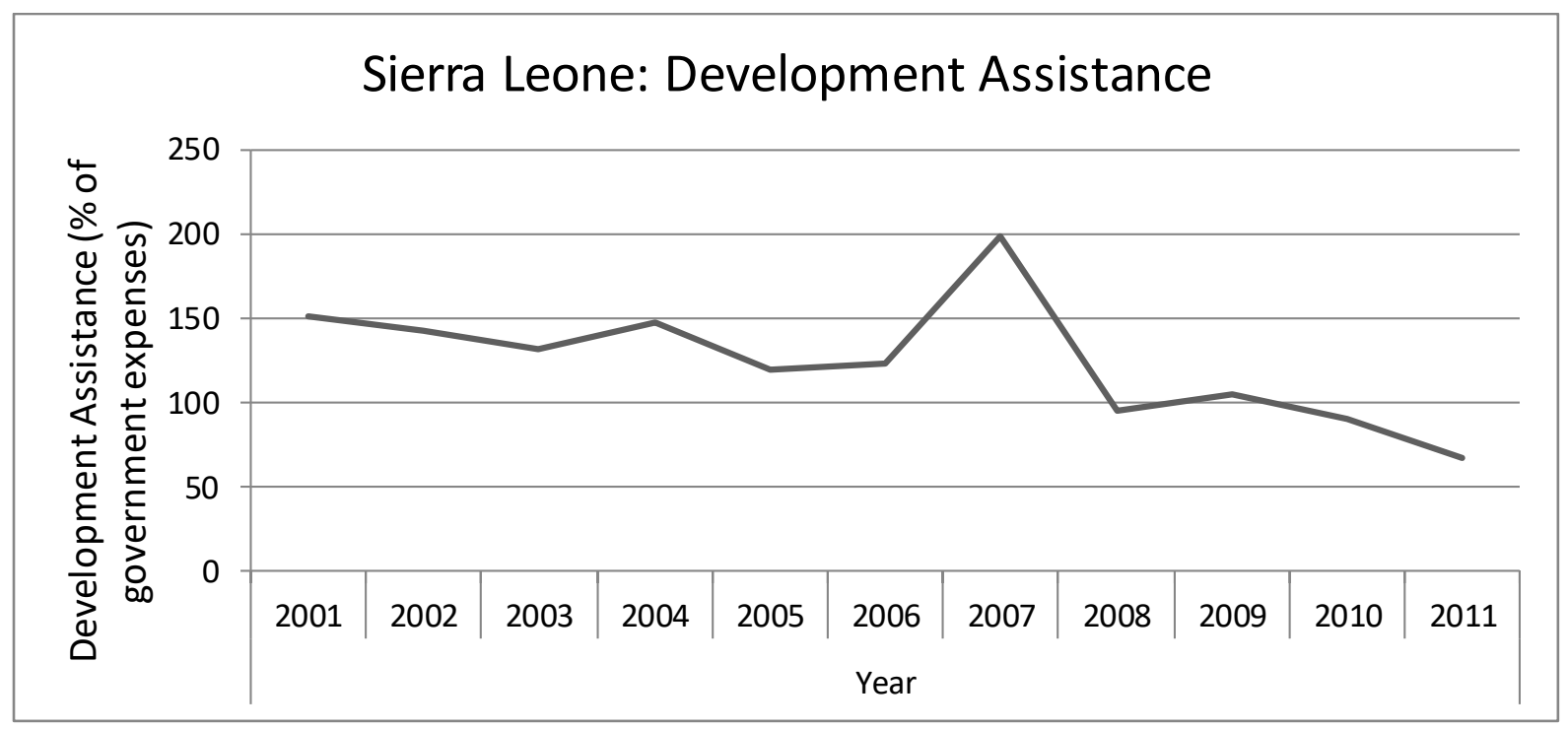

Figure 19: Official development assistance for Sierra Leone in relation to government expenses (WorldBank 2014).

In May 2002, Kabbah's SLPP government could win the first post-war elections. These elections under peace conditions legitimized and strengthened the consolidation process. Due to the progress made by the Sierra Leonean government, the withdrawal of external troops could start early. Already in 2000, the UK pulled out all but 200 soldiers who stayed in the country in order to provide further training and guidance for SSR. UNAMSIL also started to draw down its military component after the end of hostilities. By the fall of 2003, it had reduced its troop level from 17,800 to 12,000 . At the end of 2004 , only 4,100 troops were left in Sierra Leone. The withdrawal was completed at the end of 2005 (Bah 2012: 110-112). The follow-up UN mission, UN Integrated Office in Sierra Leone (UNIOSIL), took place between 2006 and 2008. It supported Sierra Leone in establishing the Truth and Reconciliation Council and in holding the 2007 elections (Bah 2012: 113-114).

To sum up, the Sierra Leonean state's monopoly on large-scale violence could be consolidated through the statebuilding intervention. After the RUF was defeated, the country's democratic institutions were successfully revived and the government was able to build professional armed forces. 


\section{Outcome: State Monopoly on Large-Scale Violence}

By 2005 , the Sierra Leonean state had acquired a full monopoly on large-scale violence. The international troops had been withdrawn, all groups capable of challenging the government's claim to the monopoly on violence were disarmed and had lost their power (RUF and CDFs), and a reliable army had been created. As the successful change of government through elections in 2007 has demonstrated, the monopoly on large-scale violence is well institutionalized: It is not 'owned' by one person or party, but is passed on from one elected government to the next. The RSLAF accepted that control over them was handed over from an SLPP administration to an APC-led government. The two major political actors, the APC and the SLPP, seem committed to the institutionalized monopoly on violence. Neither of them has attempted to repoliticize the security forces. Furthermore, the regional political setting has developed favorably for the Sierra Leonean government's monopoly on the use of force. Key political actors in the region cooperate with Sierra Leone, and this cooperation has been further institutionalized through ECOWAS. Both Guinea and Liberia acknowledge Sierra Leone's sovereignty and are committed to control their borders.

The organizational capacities of the Sierra Leonean government have greatly improved. Unlike in the pre-war era, the RSLAF are well-equipped and professionally organized. They are led by a modernized ministry which assures civilian oversight. Unlike in former times, the Sierra Leonean army is almost exclusively focused on external defense, although it can still assist the SLP if requested. A separation between defense and policing has been mostly established, even though there might still be a certain amount of distrust between the army and the police (Wikileaks 2009). A major weakness is the fact that the government is not able to fund its security forces and, thus, is still depended on ODA. However, as the last section has shown, the fiscal situation of the Sierra Leonean state has constantly improved, and the expenses for the military were significantly reduced. Thus, a development towards independent funding within this decade (2010-2020) is conceivable. Given the success in monopolizing the means of largescale violence, the conditions for the establishment of a state monopoly on small-scale violence regulation were favorable. The next section will analyze why the intervention failed nonetheless to replace self-help communities with state institutions in Sierra Leone. 


\subsection{Statebuilding Intervention and Small-Scale Violence Regulation}

Despite the great success in ending the civil war and building an army, the statebuilding intervention in Sierra Leone failed to create a state monopoly on small-scale violence regulation. Unlike in Afghanistan, many institutional structures in Sierra Leone were created before the UN and the UK started their statebuilding mission. Since the country was nominally a parliamentary democracy, the statebuilders did not foster the writing of a new constitution but instead supported the government in restoring statehood and embark on reforms. In order to create a state monopoly on small-scale violence regulation, the statebuilders wanted to dismantle the CDFs, create democratically elected local governments, democratize the chiefdom system, and build a professional police force. In 2000, far-reaching DDR and SSR programs were launched, and elections were held in 2002. Legitimized by its re-election, the SLPP-led government under Kabbah received strong support from the interveners. In the early phase of external assistance when the war was still ongoing, the British Department for International Development (DFID) supported the Kabbah administration in rebuilding the chiefdom system. After the 2002 elections, the external actors (DFID, UNDP and the World Bank) shifted to a creation of liberal institutions at the local (Thomson 2007: 22-23).

The police was initially planned as a lightly armed force that should operate according to a Local Needs Policing (LNP) approach. LNP is a different label for community-based policing in which there is meant to be a focus on a non-coercive, consensual policing style tailored to the needs of individual communities. The immense violence and destruction of the January 1999 attack on Freetown led to a general shift of the police reform to one in which enforcement capabilities play a bigger role. In particular, the SSD was not abandoned but instead re-named Operational Support Division (OSD). It was meant to become the armed wing of the new police (Krogstad 2012: 272-273). Nevertheless, community-based policing had profound impact on the SLP because it changed its organizational culture. SLP officers outside the OSD are generally unarmed (Baker 2008: 139-140). The SLP was transformed from a highly centralized organization to one that delegated important decision-making powers. "The policy put policing decisions down to the local level, but at the same time ensured that policing was carried out in accordance with national standards and guidelines" (Horn et al. 2006: 116). 
In April 1999, the UK re-launched police-building under the Common Wealth Police Development Task Force, which was re-named into Commonwealth Community Safety and Security Program (CCSSP) in 2000. Baker (2010: 4) argues that at this point, the goal of the 'police reform' was mainly to recruit officers, to provide equipment and to make the organization functional. In November 1999, it came to an agreement with the government that a British police officer should temporarily head the SLP (Fakondo 2010: 161). The idea was to have a strong and neutral police leadership that is not part of Sierra Leone's patrimonial social structure. Keith Biddle, a former British police officer, became new Inspector General Police (IGP) and reformed the organization along Western lines, in particular by introducing strictly meritocratic principles in the police rank and file (Charley and M'Cormack 2011: 18-19).

\section{The Weak State Legacy Mechanism}

Statebuilding in Sierra Leone failed to create a state monopoly on small-scale violence regulation. A long history of weak statehood triggered the weak state legacy mechanism. This failure came about despite the successful monopolization of large-scale violence, a committed SSR program and the UK's well-designed police-building mission. As the analysis makes clear, neither the creation of a 9,300-strong police force nor the introduction of elected local governments could weaken the Sierra Leonean chieftaincy system. Hence, at the end of intervention Sierra Leone was a para state marked by the co-existence of self-help communities and state institutions.

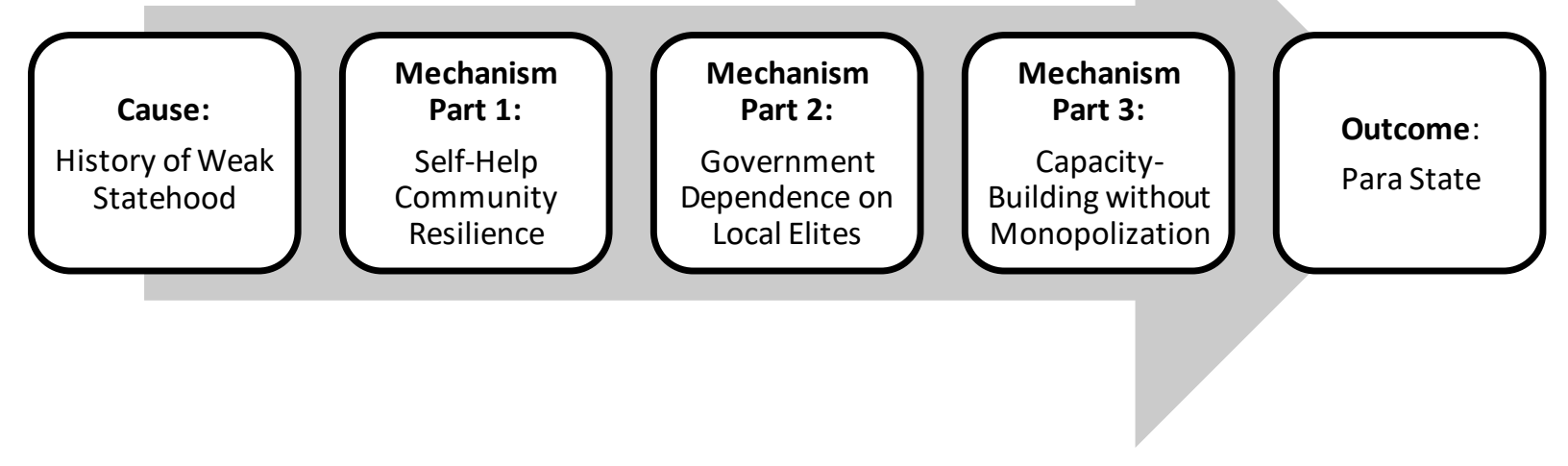

Figure 20: Weak State Legacy Mechanism. 
As in the case of Afghanistan, the cause of the failure to monopolize small-scale violence regulation is Sierra Leone's history of weak statehood. The state always had to rely on the chiefdoms as self-help communities and never managed to replace these institutions with formal local government and state policing. Hence, when the civil war began, Sierra Leone was a para state with police forces in the large cities and self-help communities spread across its territory.

(1) Self-Help Community Resilience: The Sierra Leonean civil war began in 1991. Over the following decade, most of the state police force collapsed. In contrast, the chiefdoms showed great resilience during the conflict.

(2) Government Dependence on Local Elites: When the statebuilding intervention began, both interveners and the central government relied on the support of the chiefs and local militias. In return for their support, the chiefdom system and local government structures remained untouched in the early statebuilding phase.

(3) Capacity-Building without Monopolization: Security Sector Reform in Sierra Leone was implemented early on, and the UK took the lead in training a new police force. At the same time, institutions were reformed in order to create formal democratic institutions at the local level. However, chiefdoms remained in place and their role was even acknowledged by the state.

The result is a constellation in which state police and justice co-exist with self-help communities. The Sierra Leone is a para state that has no monopoly on small-scale violence regulation. In contrast to Afghanistan, the constellation in Sierra Leone is more institutionalized as the relation between state and chiefdoms has been formalized. Nevertheless, the continued authority of chiefs limits the ability of the state to implement reforms and tax the population. 


\section{Cause: History of Weak Statehood}

The state of Sierra Leone has never acquired a state monopoly on small-scale violence regulation. Tracing the creation of state policing back to the beginning of the $19^{\text {th }}$ century, this section shows that the colonial rulers had little interest in establishing a state monopoly on of small-scale violence regulation. Instead they relied on local elites as stabilizers of their rule. After independence, the Sierra Leonean government continued this type of para statehood. Under both regimes, the police was not a tool of direct rule but one to punish unruly self-help communities.

Britain's main interest was to keep the region stable in order to ensure free commercial activity and trade. During most of the $19^{\text {th }}$ century, British rule was focused on Freetown and the policy towards the chiefs of the hinterland was one of mutual acceptance. Freetown had concluded dozens of treaties with chiefs in order to enhance commerce in the colony (Reno 1995: 32). These modest goals were slowly replaced at the end of the $19^{\text {th }}$ century, when Britain started to expand its control over a greater territory. In 1896, the hinterland was declared a British protectorate (Reno 1995). This massive expansion of political control was driven mainly by Great Power competition with France. It changed the relation between most of the elites in the colony and the British from a relation among (formally) equals to one in which chiefs had to subordinate to the colonial masters (Reno 1995: 29-30). The British concluded treaties with kings and other political leaders, which were consequently given the title of 'Paramount Chiefs'. These chiefs could be replaced by the central government at any time, but also received privileges for their loyalty. Chiefdoms became local institutions with their own sets of rules (customary law) and their own enforcement mechanisms (chiefdom policy, access to land, etc). These self-help communities were ruled by chiefs who had to be descendants from noble families. Their status was enshrined in a series of laws under colonial rules (Tribal Authorities Ordinance 1938, Chiefdom Treasuries Act 1938) as well as in the post-colonial order (Tribal Authorities (Amendment) Act 1964) (Jackson 2007: 98-99).

The first police force in Sierra Leone was created in the early colonial period. In order to establish and uphold social order, the Sierra Leone Frontier Police was created in 1808 (Baker 2008: 132). "[..] in 1901 the Governor approved a system of chief-run police (Court Messengers) charged with preserving law and order. These forces, armed with British weapons, strengthened favored chiefs against rivals in the name of the state" (Reno 1995: 37). In the 1920s, the Sierra 
Leone Police Force was created through a merger of the Court Messenger Forces and the Frontier Force. As the colonial rule draw to a close the British embarked on several reforms to prepare Sierra Leone for independence. The police forces of the colony were expanded rapidly during the final decades of colonialism, so that "[between] 1939 and 1960, the size of the police force increased almost tenfold from 290 to 2,019" (Krogstad 2012: 267-268).

Institutionalization of policing progressed in the 1960 s, when the duties of the police were specified and oversight of the force by the Ministry of Interior was further formalized in the 1964 Sierra Leone Police Act (Charley and M'Cormack 2011: 10). These early attempts to build a modern police force were retracted by the one-party-state beginning in 1978. Instead of regulating life at the community level, the police became increasingly politicized (Charley and M'Cormack 2011: 10-11). As Baker (2008: 132) argues, “[..] the police were never simply a crime prevention and crime fighting force. As the coercive arm of the colonial state they had a political role as well [..]". The regular police was complemented by the SSD in 1979. As discussed above, the SSD was located somewhere in between an army and a police force, and it could best be described as a type of paramilitary police or gendarmerie (Krogstad 2012: 274). Overall, the police was not meant to replace the chiefs with formal government arrangements as "[..] the costs of imposing direct rule ensured that this alternative intermediary system would not be scrapped" (Reno 1995: 29). Instead, its task was to keep potential challengers of the central government in check. The government had to rely on the chiefs to stabilize the countryside, to police local communities, and to generate some revenues through taxing the population (Acemoğlu et al. 2013: 9-12). Accordingly, the Stevens regime ran a patronage network that connected the center to the local elites (ICG 2008: 6-7).

In sum, Sierra Leone was a para state in which the small-scale violence regulation was controlled by chiefs in large parts of the country. The state police was mostly tasked with protecting the regime and balancing the power of non-state elites.

\section{Step One: Self-Help Community Resilience}

As discussed in the last section, chiefdoms, Sierra Leone's local institutions of small-scale violence regulation, have developed over centuries and proved stable during several political 
transitions. Hence, they can clearly be classified as self-help communities that provided rules and rule enforcement for the population and were largely accepted a legitimate. This section shows that due to these strong local roots, chiefdoms survived the decade of civil war despite being targeted by the RUF.

Traditional 'hunters' opposed the RUF as early as 1991(SLTRC 2004: Vol. 3A, Ch. 4, 289). In the early days of the conflict, local chiefdoms sporadically organized resistance against the RUF rebels. The groups who fought against the armed group consisted usually of young men from the local area who were members of so called secret societies. These men were deeply rooted in their communities and could be described as hunters who, in addition, often had knowledge of herbs and medicine (SLTRC 2004: Vol. 3A, Ch. 3, 574). The local groups were very similar in their setup, although they had different names depending on which ethnic group they belonged to. Hence, the militias were called Tamaboros (Koinadugu District), Gbethes and Kapras (Bombali, Port Loko, Tonkolili), Donsos (Kono) and Kamajors (South and East of Sierra Leone) (SLTRC 2004: Vol. 3A, Ch. 4, 289). By 1996, the central government (assisted by Executive Outcomes) had realized the great potential of organizing the hunter militia at the level of large-scale violence. The government created a unified national framework in which the militias should be coordinated. Thus, the Civil Defense Forces (CDF) were established and put under the command of Sam Hinga Norman. A chief from the Southeast, Hinga Norman became Deputy Minister of Defense and, by controlling the CDFs, evolved into the real military leader of Sierra Leone. Chiefs were tasked with the recruitment of the fighters (Wlodarczyk 2009: 203204).

Understanding the role of self-help communities during the war necessitates a discussion of the relation between CDFs and chiefs. The Truth and Reconciliation Commission for Sierra Leone has summarized their relation as follows:

The establishment of the civil defence units in the communities had been on the initiative of the chiefs. In the early days, the chiefs selected able-bodied young men from their communities and sent them for "training". With institutionalisation of the movement and the massive numbers that subsequently joined, it became impossible for the chiefs to control the membership. Furthermore, while the chiefs' retained symbolic authority in the communities, the control of men in arms created new levers of power in the communities. 
The CDF was organised both as a military and an administrative entity. Each district and town had administrators who were in charge. The function of the administrator was to ensure the maintenance of law and order, settle disputes among people and encourage the people to continue with their daily lives. The administrators had supplanted the government appointed administrative officers. Increasingly the administrators supplanted the chiefs as points of authority and contact. (SLTRC 2004: Vol. 3A, Ch. 4, 302)

In short, the chiefs retained their legitimacy ('symbolic authority') while the CDFs had acquired the means of violence that allowed them to enforce rules. This led to an uneasy relationship between the two institutions, but collaboration between CDFs and the chiefs was important for the legitimization of the militia system. Hence, the RUF did not only fight the CDF forces but also systematically targeted chief families in order to undermine the powerbase of the CDFs (Bellows and Miguel 2009: 1150).

At the end of the war, the question was whether the CDFs would agree to disarmament, and whether the many local militias would give up their powerful position and let the state or the chiefs retake control over communities. Research on the standing of CDFs indicates that over the course of the war, the militias had departed from their local roots and had developed more into an armed group (i.e. an actor of large-scale violence). The mass mobilization of militias after 1996 had little to do with the initial hunter militias who had to go through traditional initiation ceremonies. Furthermore, CDFs had committed many atrocities against the populations they were supposed to protect (SLTRC 2004: Vol. 3A, Ch. 4, 294-295). Hence, they had lost much of their early legitimacy. The quick dismantling of the CDFs after the war indicates that in Sierra Leone, tradition trumped the war-time prowess of the militias. Once the government and UNAMSIL had become powerful enough to disarm both the RUF and the CDF, the Civil Defense Forces quickly lost their violence-based war-time power in the chiefdoms. By 2001, the chiefs were engaged in the DDR process and thereby de-militarized small-scale violence regulation at their level of governance. CDF fighters acknowledged the authority of the chiefs. For example, in Kono district they did not disarm on the orders of the central government, but only when their local chiefs instructed them to lay down arms (UN 2001b). Consequently, the CDFs did not only lose their capacity to wage large-scale violence but they also disappeared as regulators of small-scale violence (Baker 2008: 153-154). 
On the side of the state, the police force had mostly vanished from Sierra Leone. The remains of the force were unprofessional and suffered from weak moral (Fakondo 2010: 161). Where police forces were still in place, they often had to accept the CDF as superiors. According to the Truth and Reconciliation Commission for Sierra Leone:

The CDF became a law unto themselves in all the districts and communities they controlled. While there were police stations in some of the districts, the police officers were hamstrung and could do nothing in the face of the overwhelming powers of the CDF. Police officers were summarily beaten for not obeying the orders of the Kamajors. (SLTRC 2004: Vol. 3A, Ch. 4, 304)

However, this subordination of the police to non-state actors was of little relevance for most of the country as the police had mostly ceased to exist outside of Freetown. Even in the capital, the SLP had little capacity to police the community. By 1999, the whole Sierra Leone Police had twelve vehicles left in service (Albrecht and Jackson 2009: 34-35). "In some areas, where state presence was limited, the SLP had never been present, and people were only familiar with traditional forms of authority; some areas of the country had been under RUF control for years, while in other communities CDF fighters had taken over the provision of security, and the imposition of law and order" (Charley and M'Cormack 2011: 25-26).

To sum up, during the civil war power in the chiefdoms shifted to the CDFs. The CDF started out as chiefdom fighters but were hard to control during the war. However, chiefs continued to be seen as the legitimate local elites and could quickly regain control over small-scale violence regulation in their communities once the war ended. In contrast, the state police forces had largely dissolved as a result of the war. As the next section shows, this constellation gave chiefs a powerful position in the early days of the statebuilding intervention. 


\section{Step Two: Government Dependence on Local Elites}

When the statebuilding intervention began in 2000, the central government of Sierra Leone had lost most of its army and police forces. Given its weakness, the state had to rely on the chiefs to stabilize the country. As a result, the self-help communities were acknowledged by the state and chiefs were granted great autonomy.

Dependence on the chiefs was the result of a weak state, strong militias and widely accepted local institutions. Early efforts to conduct SSR and rebuild the police date back to 1999. Due to its historical (post-colonial) relationship, the UK was the main actor to train the Sierra Leonean police. Before being ousted by the AFRC, President Kabbah sought cooperation with the British Department for International Development (Charley and M'Cormack 2011: 14). This cooperation was re-established after the SLPP was reinstated by Nigerian forces, but quickly interrupted when the British advisors had to leave the country due to the January 1999 RUF offensive (Albrecht and Jackson 2009).

Lacking both an army and a police force, and seeking to disarm the CDF militias after the war, the government had no capacity to govern Sierra Leone. It thus turned to the chiefs to reestablish control over the population. Already in 1996 newly elected President Kabbah announced that he would re-build the chiefdom system (Labonte 2012: 10). Given that the chiefs and CDFs were his major allies in the civil war, a strong position in the new Sierra Leone was the price for their support. Although many chiefs had been killed or expelled by the RUF, a return to the chiefdom system was possible because the institution with its rules, hierarchies and enforcement mechanisms was accepted by the (rural) population. The chiefs provided cheap and effective order on the local level. "The traditional justice and governance systems, though highly imperfect, are relatively familiar and accessible to the average community members they are meant to serve, most of whom are poor, illiterate, and largely disconnected from both the capital Freetown and the decentralized state institutions located in provincial and district headquarters" (Manning 2009: 2). As self-help communities that provided structure to the local population, the

chiefdoms were also able to absorb young men who fought for the CDFs and were now expected to reintegrated into civilian life (Baker 2010: 11). Furthermore, since the administrative capacities of the Sierra Leonean state were very weak the state lacked tax revenues. In their traditional role as tax collectors, the chiefs provided the government with a way to create tax 
revenues without having a strong local administration in place (Jackson 2005: 53-54). Hence, the chiefdoms regulated small-scale violence in a country devastated by civil war, and in return local elites enjoyed great autonomy.

As a result, "[r] estoring paramount chiefs became an important part of the strategy for regaining control in the countryside and encouraging the return of refugees" (Thomson 2007: 7). "Between 2000 and 2002 [..] 149 paramount chiefs were reinstalled throughout the country" (Labonte 2012: 10). In the re-established chieftaincy system, the paramount chief is the highest 'traditional' authority. Paramount chiefs are elected for life time by a Tribal Authority (see next section), govern underneath the district level and control their own staff. Additionally, they controlled the local court system. Within the paramount chiefdom, petty chiefs govern smaller towns and villages (Manning 2009: 3-6). Chiefs were able to build their patronage network into national politics as they are often members of the two main parties (APC and SLPP). Many members of parliament depend in the support of the chief of their constituency. Due to their land rights, many chiefs control diamond mining and have thus great resources to influence national politics (Jackson 2007: 101-102).

In the period between the Lomé Agreement (1999) and the end of the civil war (2002), the chiefdom system became again a major pillar of the state. Chiefdoms worked as self-help communities because they were well institutionalized and could regulate small-scale violence. The statebuilding intervention as well as the government had to rely on the chiefs in order to stabilize the country. Therefore, the chiefs were in a strong position when external actors started their effort to create a state monopoly on small-scale violence regulation in 2002.

\section{Step Three: Capacity-Building without Monopolization}

Efforts to monopolize the regulation of small-scale violence began in earnest in 2002 after the statebuilding intervention had defeated the RUF. It entailed the creation of formal institutions, but its main focus was on the training of a professional police force. This section shows that while the statebuilders endowed the state with greatly enhanced capacities, the chiefs successfully defended their self-help communities. 
The expansion of formal state institutions to the local level has shown some progress. However, despite international support for the creation of liberal institutions, chiefs had great influence on the institutional architecture of post-war Sierra Leone. A major step of increasing the government's reach was the enactment of the Local Government Act in 2004. For the first time since the local administration was abandoned by Stevens in 1972, Sierra Leone created state institutions at the local level (Labonte 2012: 13-14). Local government thereby became democratically legitimized. Furthermore, local councils have also received the right to tax their constituency. However, the reform was watered down by the Kabbah administration in order to please the chiefs that had supported the SLPP. Since the local councils depend on the chiefs to collect taxes, they de facto depend on the traditional authorities (Thomson 2007: 23). At the same time the law formalized the duality between traditional and state authorities, thereby further institutionalizing the authority of the chiefs (Jackson 2005: 51-52). While the local government reform created democratic local institutions, it did little to enhance the democratic accountability of chiefs. Access to chiefly offices is restricted to few noble families as "[..] paramount chiefs rule for life, and are elected by vote of the 'Tribal Authority', a group comprising the members of the chiefdom elite" (Acemoğlu et al. 2013: 9). Hence, local elites had great discretion and were not democratically accountable to their constituent communities. During the intervention, the chiefs also kept their important role in nominating chairmen for the local court system. The legal foundation for these powers dates back to the 1963 Local Courts Act (Manning 2009: 5). Overall, the formal institutions created by the Sierra Leonean parliament under international supervision have created a form of institutionalized legal pluralism.

While the formal institutional framework has devised roles and powers to the different actors, the external police-building mission has endowed the central government with the organizational capacities to actually enforce political decisions. At the end of the war, the police force consisted of about 6,500 officers who were ill-equipped, ill-trained and confined to the capital; it could be considered one of the war's many militias rather than a proper police force. Nevertheless, police men were reinserted step by step into the districts that had been brought under army control in late 2001 (UNSC 2001e: 4). However, only in 2002, after the conflict was officially declared over, was the government able to field a substantial number of police units in cities outside Freetown. However, the number of police personnel was still the same, and recruitment of qualified individuals remained a problem. "By 2004 police barracks had been 
built and more than 700 vehicles had been provided to the police. Yet at 6,000 officers $(2,400$ of whom were part of the armed wing, the Operational Support Division - OSD) the SLP was still too small to handle a situation where: there were still hostile armed groups present in the countryside; there were combatants yet to be disarmed and reintegrated; and in addition there were rising levels of reported crime and potential political public disorder" (Baker 2010: 4). Nevertheless, over the following three years the police was continuously expanded until it reached its full strength of 9,300 officers in 2005 (Baker 2008: 140).

Internally, the police has become more professional but still struggles with corruption. In a country that is one of the poorest in the world, and in which the government struggles to fund its operations independently of external aid, it is difficult to pay competitive wages to police officers. Regarding this issue, IGP Biddle himself showed some understanding for the SLP in 2001: "There's a certain amount of sympathy from some of the populace to give the policeman 200, 300, 500 leones when he puts his hand out. [..] So it's a question then, is this corruption, begging, or is it really people supplementing a policeman's wages? It's very difficult" (Andersen 2001). In addition, the court system is seen as slow, expensive and inefficient (Baker 2008: 138139). Thus, even when the SLP works properly, people cannot be sure that their claims will be dealt with by the courts in a fair and timely manner.

As a result of the simultaneous existence of state institutions and self-help communities, the relation of police and chiefs was often tense. Police officers had to deal with a complex distribution of responsibilities and powers. As one Sierra Leonean police officer recalls,

At meetings with stakeholders and key decision-makers, I witnessed first-hand how much the locals trusted the Kamajors, which contrasted heavily with my experience of our police station, which was generally avoided. I was able to ascertain that the issue was mostly down to trust: the Kamajors were trusted, the police were not. Years of police corruption had left our reputation in tatters and bolstered that of the Kamajors. This did not change the fact that the Kamajors were not the legitimate body to administer justice but it did show that we needed to work with them. (quoted in Charley and M'Cormack 2011: 26) 
Thus, he describes the process of re-introducing the police to rural communities as a highly delicate endeavor, because the aspiration of the government to enforce national law had to be reconciled with the presence of strong local institutions (Charley and M'Cormack 2011:26-27).

Despite the careful approach of the police, chiefs have felt that the SLP is trying to disempower them. Denney (2013: 11) cites paramount chiefs who argue that they are the 'backbone' of security in local communities, but who feel that the SLP is increasingly interfering in areas that should be ruled through traditional mechanisms. This shows that the biggest challenge for a monopolization of small-scale violence regulation in Sierra Leone is not a lack of organizational capacities on side of the SLP, but the political backlash that any move towards monopolization could produce. Although (or because) their power does not rest on liberal principles such as democracy or equality, field research shows that the chiefs still enjoy a very high degree of legitimacy among the population (Denney 2013: 7-8). For the SLP, the existence of these local institutions creates a bottom-up problem. Individuals who have become victims of crime often times do not turn to the state police. Instead, they seek justice from traditional authorities whom they might see as more trustworthy or efficient. The SLP is approached only in cases of severe crimes (Baker 2008: 141-142).

The bottom line is that the formal institutions and state policing have strongly improved, but they have not replaced the non-state institutions. Instead, chiefs are powerful enough to retain their self-help communities. As a result, a the Sierra Leonean state has both a strong police force and liberal institutions, but is not powerful enough to directly challenge the chief's autonomy.

\section{Outcome: Para State}

As a result of the statebuilding intervention, Sierra Leone is a para state that combines state institutions of small-scale violence regulation with self-help communities. In a strict sense, this outcome is a failure of liberal statebuilding because the chiefdoms effectively block the development of a bureaucratic state that could make laws and enforce them without local elite interference. However, the intervention has created a set of institutions that could enable the state to hollow out chiefdoms in the long run. 
The SLP has made progress since the end of the war. Its organizational capacities have been greatly improved, especially given that there was not much left of the police when the intervention started. The personnel target has been met, and the SLP is comparatively well equipped. Furthermore, a stronger emphasis on meritocracy has entered into the organizational culture of the SLP. The police are seen much more favorable than it has been the case in the past. Nevertheless, police officers are still not paid well and corruption remains wide-spread. In terms of institutions, the introduction of elected local councils could put pressure on chiefs to address the needs of their communities. Due to the effective parliamentary democracy of Sierra Leone, the electorate could also demand institutional changes from the central government if chiefs do not fulfill their expectations or even drift back to their abusive rule of the pre-war era. Since the end of the intervention, the government has made small steps towards increased control over the local level. Most importantly, the role of chiefs in formal justice has been reduced. The 2011 Local Courts Act has abandoned the chief privilege of nominating the chairmen of local courts (Denney 2013: 10-11). Election procedures for paramount chiefs have also been modestly reformed. The 2009 Chieftaincy Act stipulates that the Chiefdom Council should include "[..] Councilors, each representing every twenty taxpayers in the chiefdom [..]” (SL 2009: II, 4, (2)). "Still, however, the Tribal Authority comprises mostly members of the rural elite; they are not elected by these taxpayers and neither is the paramount chief" (Acemoğlu et al. 2013: 10). Furthermore, participation is greatly restricted as many women and poor people are not taxpayers (Jackson 2007: 98).

Despite these incremental steps, the available data provides strong evidence that the chieftaincy system enjoys popular support. A representative survey conducted between 2010 and 2012 shows that the police have been rehabilitated since the civil war, but also that it is still far from being the sole enforcer of the law (Afrobarometer 2013: 9). Asked whom they turn to if they become victim of a crime, the majority (51\%) of Sierra Leoneans name the police (see fig. 21). However, $34 \%$ of respondents still prefer traditional institutions over the official police force. The picture changes further if one compares urban and rural areas. Whereas the urban population has clearly favors the police $(67 \% \mathrm{v} .16 \%$ traditional), people living in rural areas still have more confidence in traditional institutions $(45 \%$ v. $41 \%$ police $)$. This constellation corresponds to the fact that during the war, the SLP was present only in larger cities and, later on, only in Freetown. Given that still about $60 \%$ of Sierra Leoneans live in the countryside, this poll 
shows that even after ten years of peace and capacity building, the state is far from wielding strong infrastructural power.

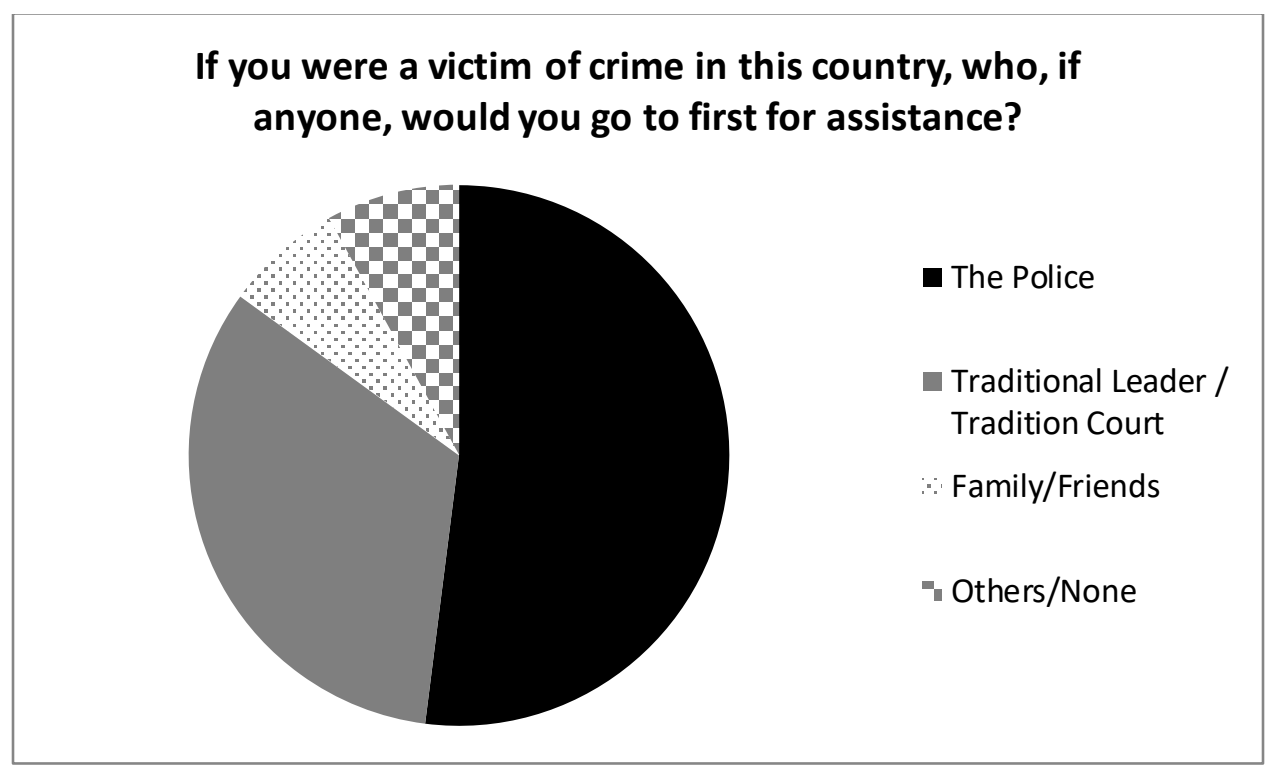

Figure 21: Demand for institutions of small-scale violence regulation in Sierra Leone (Afrobarometer 2013).

\subsection{Conclusion}

The statebuilding intervention in Sierra Leone has failed to build a state monopoly on violence, yet it has succeeded in bringing peace to the West African country. While it has achieved a monopoly on large-scale violence, small-scale violence regulation remains in part with self-help communities. However, the case of Sierra Leone offers some important insights regarding the monopolization of the use of force. With regard to large-scale violence regulation, the case highlights the central importance of regional politics for statebuilding interventions. The combination of a UN statebuilding intervention and regional cooperation proved sufficient for a successful monopolization of large-scale violence. Prior to UNAMSIL, the regional intervention into the civil war failed to defeat the RUF as it lacked both the means (equipment, qualified troops, etc.) and the strategy (DDR, SSR). When the UN intervened decisively, it took about a year to cut off the RUF from its Liberian sanctuary. Subsequently, the armed group collapsed quickly and the statebuilders could create a new, reliable army. The consolidation phase offers a marked difference to the Afghan case, where the armed forces have been inflated to an absolutely 
unsustainable size. In contrast, Sierra Leone's cooperative neighborhood enables the government to rule the country with a small professional force. The case of Sierra Leone also illuminates the old debate over the timing of democratization and monopolization. Civil war, poverty, ethnic heterogeneity, and the presence of resources are usually seen as detrimental to democracy. However, the successful institutionalization of large-scale violence regulation has paved the way for an electoral democracy which has proven robust after the intervention. The RUF transformed into a political party and was defeated at the ballot box.

However, the chapter also offers a stark reminder of the gap between large-scale violence and small-scale violence regulation. Despite the achievements at the macro level, Sierra Leone remains a para state in which small-scale violence is regulated both by state and non-state institutions. While the well-coordinated police-building program and the introduction of local government have clearly increased the state's capacities, the deeply rooted authority of chiefdoms has led to an early (local) elite capture of the statebuilding process. Although they share the same outcome, the relation of state and self-help communities differs greatly in the cases of Sierra Leone and Afghanistan. Whereas Afghanistan has no officially recognized self-help communities, the relation between Sierra Leone's chiefs and the government are well institutionalized. As a result, Afghanistan's local government institutions are controlled by strongmen, whereas Sierra Leone experiences a strong dualism between its formal, democratic institutions and its illiberal chiefdoms. Despite being well regulated, the negative consequences of para statehood are also felt by the Sierra Leonean state. The reliance on chiefdom structures for tax collection and the limited reach of the police negatively affect the central government's ability to effectively tax the population (the so-called 'extractive capability'). This is reflected by the meager tax-to-GDP ratio and especially it's weak development since the end of the war, given that "[..] Sierra Leone's revenue to GDP ratio fell from 12.3 percent in 2003 to 11.9 percent in 2005 and to 11.7 percent in 2009" (Davies and Dessy 2012: 7). Furthermore, the state is often unable to properly deliver public goods in rural areas.

Overall, the statebuilding intervention in Sierra Leone has achieved a lot in terms of peacebuilding. The case shows that even a partial monopolization of violence can greatly improve the quality of life in a given country. It remains to be seen whether UNAMSIL will become the foundation for long-term state formation or whether its achievements will prove 
unsustainable, leaving Sierra Leone with the preconditions for weak statehood and the next civil war. 


\section{Bosnia-Herzegovina}

The international intervention in Bosnia-Herzegovina was conducted to end the gravest violence in Europe since the end of the Second World War. With the dissolution of Yugoslavia, which began in 1991, the Balkan region was politically destabilized. The Bosnian War was the worst outcome of this process of state dissolution and state formation. Whereas Slovenia and Croatia emerged relatively peaceful as new states, Bosnia-Herzegovina experienced a war between its major ethnic groups: Muslim Bosniaks, Bosnian Serbs, and Bosnian Croats. As in most other cases, the intervention escalated slowly from a peacekeeping mission in 1992 to large-scale statebuilding effort in 1995. In 2007, the size of EUFOR was drastically reduced to only 1,600 troops, thereby de facto seizing to be a statebuilding intervention. However, twenty years after the intervention had begun the international community still has veto power over political decisions in the country. However, and in contrast to most analyses of the case at hand, this chapter argues that the statebuilding intervention in Bosnia-Herzegovina was a success in terms of regulating violence: Statebuilding intervention in Bosnia-Herzegovina has resulted in a full state monopoly on violence.

When the intervention began, large-scale violence was the prime issue. Through a combination of military coercion and political bargaining, the parties of the conflict could be forced to sign a peace treaty which subsequently became the constitution of the new state. Until 2000 , however, there was little to suggest that a monopolization of large-scale violence could be possible. Both the former government (Federation of Bosnia-Herzegovina) and the defecting Serb polity (Republika Srpska) had created monopolies of violence in their respective parts of the country. However, the regional structure changed in the case of Bosnia from a competitive to a cooperative environment. Especially since 2000, Croatia and Serbia have begun to cooperate with the EU and NATO. In this context, the international intervention resulted in the unification of the

armies into the new Armed Forces of Bosnia and Herzegovina in 2005. Thus, while the country still suffers from ethnic divisions and institutional blockades, the government has achieved a monopoly on large-scale violence.

With regard to the regulation of small-scale violence, the intervention can also be considered a success. Before the war, small-scale violence regulation was monopolized by the 
state, albeit by the Socialist Federal Republic of Yugoslavia. During the conflict, the socialist police state was increasingly politicized, fractured along ethnic lines, and became a tool for ethnic cleansing. Simultaneously, a large number of local militias emerged and was coopted by the armed groups to defend communities or commit atrocities. However, unlike in Afghanistan or Sierra Leone, these militias did not evolve into deeply rooted self-help communities during the short period of civil war. Instead, the population had been socialized into state rule for decades, and expectations were centered on state agencies controlling small-scale violence. Given the lack of self-help communities, it was possible for the statebuilding intervention to re-build the state's police force. The outcome was a state monopoly on small-scale violence regulation.

While Bosnia is a major case of peacebuilding research, little focus has been put on questions relating the regulation of violence. The most likely reason for the lack of explanations is the fact that the intervention was a success with respect to violence: There was little inter-personal violence after the war, and no more collective violence between the entities. One of the few scholars who tried to explained the positive outcome are Berdal et al. (2012: 76-77), who argue that there are two reasons for the absence of wide-spread post-conflict violence: The intervention accepted the gains of the warring parties, and it deployed an overwhelming military force. However, these explanations are not convincing. With regard to the entities, it is true that the intervention approach was very careful in its effort to monopolize large-scale violence. Nevertheless, it integrated all three armed forces into one national army without any armed resistance. Given the degree of military organization of the factions, especially in Republika Srpska, the non-violent disarmament of war-time actors is rather surprising. In contrast, the argument that the size of the intervention force was the decisive factor does not hold in comparative perspective. After all, UNAMSIL succeed in Sierra Leone although it was rather small compared to either IFOR or to the failed statebuilding efforts in Afghanistan and Iraq.

In the case of Bosnia-Herzegovina, there has been disagreement not only over specific explanations but also over whether the intervention could be considered a success or a failure with regard to the regulation of violence. In terms of small-scale violence regulation, the failure of the EU to centralize the police force and re-order its districts has been interpreted by some as a major failure of international police-building (Ahić 2007: 376-377 ; Muehlmann 2008: 14) . 
Critics are right to point out that the fragmented structure is disproportionally expensive and makes inter- and intra-entity police cooperation more difficult (Ahić 2007: 377 ; ICG 2005: 2 ; Juncos 2011). However, it seems highly questionable to define success in terms of centralization as many OECD member state have decentralized police forces that are controlled by communities or federal states ${ }^{29}$. Another major issue is the high level of corruption in the Bosnian police force (UNODC 2011: 23-27). While this certainly points to a failure in establishing the rule of law, it does not constitute a failure of monopolizing small-scale violence regulation in the hands of the state. The role of the state police in maintaining order in Bosnia-Herzegovina is undisputed. As this chapter will show, the most important aspect of policebuilding is that there is no non-state competitor to the state's law enforcement system: The state has a monopoly on small-scale violence regulation.

With regard to large-scale violence regulation, there have been suspicions that Bosnia's armed forces are only formally unified. Some authors have argued that the structure of the armed forces is still based de facto on the ethnic armed groups it has replaced (Berg 2014: 158). The regiments as well as infantry battalions that are based on ethnic principles, i.e. they are ethnically homogenous. In case of increased inter-ethnic conflict, it is conceivable that these structures are used to re-ethno-nationalize the armed forces. However, in practice this does not seem to play an important role for the armed forces. The regimental structure is symbolic only, and the most important operational unit, the brigades, is of multi-ethnic composition. Most importantly, in contrast to the army of the $\mathrm{FBiH}$ there is only one chain of command in the unified army (Maxwell 2014). Therefore, despite some remaining weaknesses it seems appropriate to classify Bosnia-Herzegovina as a state with a monopoly on large-scale violence.

The chapter will briefly discuss the broader context of state formation and civil war in Bosnia-Herzegovina. It then proceeds by analyzing the processes of monopolization during the statebuilding intervention by presenting a causal mechanism for each type of violence regulation.

\footnotetext{
${ }^{29}$ Examples include the community-based policing approach in Great Britain, and the Länder-based police in Germany in which police forces are controlled by the state governments, not by the federal government.
} 


\subsection{State Formation and Civil War in Bosnia and Herzegovina}

When NATO intervened in Bosnia-Herzegovina and set out to build a liberal state, it did so in a country that had experienced centuries of state formation. Since the long history of state formation distinguishes $\mathrm{BiH}$ from the great majority of intervention cases, it is important to provide this context for the analysis of statebuilding through NATO and the EU. Given that BiH was not a sovereign state since the Middle Ages, the fact that it nevertheless experienced the development of strong state institutions can easily be overlooked. The formation of the Bosnian state has been largely shaped by two political orders. From the Middle Ages to the First World War, it has been part of imperial orders. Since the early $20^{\text {th }}$ century, it was part of Yugoslavia until its breakup in the early 1990s. Compared to most other cases of statebuilding intervention, Bosnia-Herzegovina was part of a comparably strong state with a developed economy. However, the disintegration of Yugoslavia and the declaration of independence by Bosnia-Herzegovina resulted in a civil war that shattered much of the existing order. Eventually, the current polity was shaped by the statebuilding intervention that ended the war in 1995.

\section{Historical State Formation}

Compared to typical intervention cases, Bosnia-Herzegovina has existed as an entity for a very long time. After a brief period of independence in the $14^{\text {th }}$ and $15^{\text {th }}$ century, BiH's social order was strongly shaped by five centuries of Ottoman rule. After a few decades of Austro-Hungarian occupation, the country became part of Yugoslav states for almost another century.

The polity that would become Bosnia-Herzegovina later on can be traced back to the $12^{\text {th }}$ century when Bosnia declared itself an independent kingdom. In 1326, Bosnia conquered Herzegovina, and until the $15^{\text {th }}$ century, the kingdom successfully resisted attempts of its neighbors to bring it under their control. However, in 1463, Bosnia was conquered by the Ottoman Empire (and Herzegovina followed in 1483) (Lampe 2000: 18-20). As a result, a great portion of the population converted from Christianity to Islam. Later on this improved Bosnia's and Hercegovina's position within the Empire because the main geopolitical competitor in the 
region was the Catholic Austrian Habsburg dynasty (Oschlies 2004: 745). Already in this early period, statebuilding took place through the Ottoman Empire. "The Ottomans successfully imposed a centrally controlled regime of land tenure, tax collection, and native religious rights that in practice approached the responsible local government that the medieval South Slav states had failed to establish" (Lampe 2000: 20). With the Congress of Berlin in 1878, the declining Ottoman Empire had to hand over Bosnia to the Austro-Hungarian Empire, which annexed Bosnia-Herzegovina officially in 1908 (Lampe 2000: 83-84). While the empires provided the region with an institutional setting that brought stability and modest wealth, they also hampered the endogenous development of Bosnian institutions. As a result, Bosnia-Herzegovina remained a decentralized agricultural society during the $19^{\text {th }}$ century that consisted of a small landowning elite (mostly Muslim) and a large peasantry (mostly Serb) that lived in a quasi-feudal arrangement. Apart from sporadic peasant revolts and conflicts between landowners and the central authorities, Bosnia-Herzegovina did not experience the type of large-scale wars that boosted Western European state formation (Malešević 2012: 309-310).

State formation on the Balkans, as well as in Eastern Europe as a whole, was greatly accelerated by the collapse of empires. The imperial era in Bosnia ended with a series of wars in the early $20^{\text {th }}$ century. In the First Balkan War 1912, Bulgaria, Greece, Montenegro, and Serbia defeated the Ottoman Empire and pushed it out of most of Southeastern Europe. In the second Balkan War 1913, Bulgaria turned on its allies and suffered a defeat in which the Ottomans captured back some of the lost territory (Hösch 2008: 182-184). The two Balkan Wars of 1912 and 1913 marked a new quality of organized violence for the region and Bosnia-Herzegovina and led to the death of several hundred thousand people (Malešević 2012: 311). The outcome of the wars put Serbia into a powerful position in which it would ultimately be the 'lead nation' of the future Yugoslav state. Thus while $\mathrm{BiH}$ was not actively involved, these wars set the stage for the destruction of the century old order in the region and the unification of the South Slav people.

The defeat of the Austria-Hungary as well as Turkey in the First World opened the path towards state formation in the Balkans. Serbia, after suffering huge losses during the war, became the strongest military player and therefore the leader of statebuilding. Consequently, Bosnia and Herzegovina became part of the first South Slave state: The Kingdom of Serbs, Croats and Slovenes (Glenny 2012: 365-366). The negotiations for a common constitution lasted from 1918 to 1921. Based on a French model of statehood, the kingdom was highly centralized and for a 
brief period, it was governed democratically. Bosnia-Herzegovina had the status of a province, and in 1928 the first provincial elections were held. However, democracy collapsed in 1929 when the king installed a more authoritarian regime at the center of the state. From 1929 to 1941, the government sought to further centralized and bureaucratize the state through reforms that affected among others administrative structures, the legal system, taxation, and education (Lampe 2000: 164-168). The first Yugoslav state ceased to exist when the Axis powers conquered the Balkans.

While the Second World War was a highly destructive catastrophe for Yugoslavia, it also triggered another boost to state formation. Formed through the partisan warfare against the Germans, Yugoslavia was re-established in 1945 under the leadership of Josip Broz Tito. The rule of the Socialist Federal Republic from 1945 to 1991 should become the strongest period of state expansion for Bosnia-Herzegovina. The League of Communists of Yugoslavia (Savez komunista Jugoslavije, SKJ) embarked on an ambitious statebuilding endeavor. All means of coercion were directly answerable to the party, which used these tools to defend its rule both against other states and any internal competitor (Bliesemann de Guevara 2009: 172-174). Nevertheless, the SKJ did not centralized power as strongly as socialist parties in the Warsaw Pact or East Asia did. Hence, during the 1960s and 1970s, the party was decentralized and the federal states were strengthened. An integral part of the communist rule in Yugoslavia was the charismatic leadership of Tito, who remained a focal point of Yugoslav identity until his death in the 1980 s.

In the SFR Yugoslavia, the armed forces played a central role in ruling society. They were divided into the regular Yugoslav People's Army (Jugoslavenska Narodna Armija, JNA) and the Territorial Defense (Teritorijalna odbrana, TO) forces. The large size of the JNA was sustained through conscription. Its generals were selected according to a quota to represent the ethnic groups which made up the Yugoslav population. While the army was controlled by the central government, other parts of the defense system were rather decentralized. Under the impression of the Soviet intervention in Czechoslovakia, the Territorial Defense system was introduced at the end of the 1960s. There was no strict separation between the military and society, but a high degree of societal militarization. Although Yugoslavia was a socialist state, the main reason for the strong militarization was the fear of a Soviet invasion. The system of 'people's defense' was meant to raise the prospect costs of any attempts to seize parts of Yugoslavia's territory. (Bliesemann de Guevara 2009: 172-177). 
To sum up, Bosnia and Herzegovina was a republic in a highly militarized socialist state. The central government of the SFRY had a strong monopoly on violence. It controlled the means of large-scale violence, which in the Yugoslav case consisted of a strong army that was a pillar of the one party system. The state intensively policed the population through regular and secret police, and there was no non-state institution that regulated small-scale violence. The population was socialized into a society that was completely dominated by the state. Despite these strong institutions, the state eventually dissolved and civil war ensued.

\section{Civil War}

NATO intervention in Bosnia-Herzegovina aimed at ending a civil war that had developed into the most deadly conflict in Europe since the Second World War. The civil war was a direct consequence of the breakup of the Federal Socialist Republic of Yugoslavia. Since the death of Tito in 1980, the political elites of the republics were increasingly polarized. With the end of the Cold War, the centrifugal tendencies accelerated and eventually led to the declarations of independence by Slovenia and Croatia in June 1991 (Kalyvas and Sambanis 2005: 192-193). The rise of ethno-nationalist actors was problematic for states such as Croatia that hosted ethnic minorities within their state borders; for an ethnically divided republic like Bosnia it was a disaster. While the Bosniak majority, representing the government of Bosnia-Herzegovina, fought for unity, Croats and Serbs fought either for secession or irredentism.

In the aftermath of Tito's death in 1980, constitutional reforms increasingly devolved power to the level of the states. Reacting to these centrifugal tendencies, Serb elites tried to counteract the fragmentation of power by increasing their control over the Yugoslav institutions. The subsequent split of the communist party and the victories of nationalist parties in most of the federal republics in 1990 opened up the gates for the eventual disintegration of the state (Hösch 2008: 274-277). The SFRY's monopoly on violence fractured; its armed forces were increasingly controlled by the Serbs under Milošević, while other parts of the federation build their own military forces and eventually declared independence in 1991 (Slovenia, Croatia, Macedonia) and 1992 (Bosnia-Herzegovina) (Kalyvas and Sambanis 2005: 192-193). The result was a collapse of the SFRY, and the creation of the Federal Republic of Yugoslavia (FRY), which was later renamed to Serbia and Montenegro. 
The dissolution of Yugoslavia was accompanied by a homogenization of its armed forces. Against the backdrop of Slovenian and Croat demands for independence, the SFRY's elected President Slobodan Milošević began to release all military leaders who were non-Serb. Thus, by 1991 the army had been turned into a Serb-dominated institution. The monopoly on violence in Yugoslavia (and $\mathrm{BiH}$ ) was increasingly controlled by one ethnic group. This only added to the existing tensions between the ethnic parties on the one hand, and $\mathrm{BiH}$ and its neighboring states on the other hand. Against this backdrop, all involved actors began to prepare for war during 1992 (Burg and Shoup 1999: 119).

In Bosnia-Herzegovina, the central government was dominated by Bosniaks and Croats. After contentious debates between Bosniaks and Serbs over the question whether BiH should remain with Yugoslavia or become a sovereign state, President Itzetbegovic opted officially for independence. While he had support of a great majority of Bosniaks and Croats, Serb elites opposed the move towards independent statehood. They preferred $\mathrm{BiH}$ to stay a part of Yugoslavia. However, for Izetbegovic and many of his followers, the rest of Yugoslavia was nothing more than a Greater Serbia. A referendum in February 1992 indicated a majority for independence (62.7\%), and on March 3 1992, in the absence of Serb parliamentarians, the parliament voted for independence (Burg and Shoup 1999: 117-118).

In response, the Serbs began para-military operations and a campaign of ethnic cleansing in order to foster control over their territories. The armed forces of the Republika Srpksa (VRS) were a product of the retreat of the JNA. Those units of the JNA that were stationed in RS were handed over to the newly found republic, giving it a head start vis-à-vis the Croat and Bosnian polities. As a result, the VRS controlled up to 80,000 troops as well as "[..] an estimated 330 tanks, 400 armored personnel carriers, 40 fighter jets, 30 helicopters, and a wide array of artillery in use by mechanized, mountain, and regular infantry brigades" (Christia 2012: 160). Bosniak forces were only created in late 1992. The Army of the Republic of Bosnia and Herzegovina (ARBiH) was initially disorganized, ill-equipped, and consisted of up to 60,000 soldiers. Croats organized in the Hrvatsko vijeće obrane (HVO) and were well organized, but they only commanded 45,000 troops which lacked offensive capabilities (Christia 2012: 153-154). Bosniak and Croat forces were partly built upon the foundation provided by the Territorial Defense system that had prepared Yugoslavia to counter a Soviet invasion (Bliesemann de Guevara 2009: 179-180). Within days after the declaration of independence, the state monopoly on violence had 
collapsed and it was replaced by a market of violence. The Bosnian war had a strong ethnonationalist component. In 1991, police units first resorted to tactics of ethnic cleansing in order to expel members of other ethnic groups from their territory. To varying degrees, all sides sought to ethnically homogenize their polities by expelling other ethnicities from their territories through intimidation or mass-killings.

International intervention began during the civil war. As in most other cases, the intervention was not conceptualized as statebuilding from the very beginning, but displayed the familiar pattern of slow escalation. In 1992, the United Nations Protection Force (UNPROFOR) was deployed to $\mathrm{BiH}$ in order to guarantee the delivery and protection of aid to the civilian population. The mandate was expanded in 1993, when the UN started to designate safe areas to directly protect civilians. Although they lacked a robust mandate, UN troops deployed to those areas where violence against civilians was the starkest (Costalli 2014: 13-15). In 1994, UNPROFOR turned into an actual peacekeeping force in that it now monitored the peace agreement between Croats and Bosniaks. The same year, NATO first got entangled into the war when it enforced the UN flight zone. Increasingly, the UN relied on NATO to protect its safe areas through airs trikes against Serbian forces. Despite initial successes by the well-organized Serbian forces, by early 1994 the war took a turn in favor of their opponents. After all sides had to varying degrees switched alliances, Croatians and Bosniaks signed a ceasefire and subsequently a peace treaty (Washington Agreement), effectively joining forces against the Republika Srpska. This alliance resulted in the establishment of the Federation of Bosnia and Herzegovina, today's second entity. The newly created armed forces were further emboldened by the lifting of the arms embargo through the US. By mid-1995, the Federation forces had gained momentum and could force the VRS into a stalemate (Christia 2012: 162-164).

It can be argued that the culmination point of the war was the occupation of Srebrenica by VRS forces in July 1995. Despite being designated a safe area by the UN, the Serbs could conquer the city and subsequently killed about 8,000 civilians. This genocidal act shamed NATO into action. With the war in a stalemate and Serbian forces committing a string of massacres in contested areas, NATO intervened in August 1995 with an aerial bombardment campaign that eventually forced the RS to the negotiation table (Burg and Shoup 1999: 342-344). The result 
was the Dayton Agreement of November 1995, which paved the way for the statebuilding mission IFOR. The war in Bosnia-Herzegovina was the deadliest conflict in Europe since the Second World War. Recent estimates of war-related deaths in the Bosnian civil war count a minimum of about 100,000 war-related deaths (BBC 2007; Zwierzchowski and Tabeau 2010: 1516). In addition, tens of thousands of women were raped, and the war turned over a million civilians into refugees (Burg and Shoup 1999: 169-171).

The following two sections analyze how the international statebuilding intervention affected the regulation of large-scale and small-scale violence in Bosnia-Herzegovina. While the next section shows that cooperative regional actors enabled the intervention to succeed in establishing a state monopoly on large-scale violence, the section thereafter explains how a long-term state formation in the Balkans cause the intervention to successfully monopolized the regulation of small-scale violence.

\subsection{Statebuilding Intervention and Large-Scale Violence Regulation}

Statebuilding intervention in Bosnia-Herzegovina not only ended a civil war, but it resulted in the establishment of a state monopoly on large-scale violence. This section shows that the cause of successful monopolization was the cooperative behavior of key regional actors. Before presenting the causal mechanism in detail, it will briefly describe the policies with which the statebuilding intervention embarked on monopolizing the means of large-scale violence.

The statebuilding intervention in Bosnia-Herzegovina initially aimed at ending open largescale violence, and then increasingly sought to institutionalize its regulation. The Dayton Peace Agreement (DPA) was the basis for statebuilding in Bosnia. Following the UN Security Council Resolution 1031, IFOR began the deployment of its 60,000 troops to Bosnia in December 1995. "The IFOR mission included ensuring compliance with the cease-fire, ensuring the withdrawal and separation of forces, ensuring the relocation of all heavy weapons and military forces to cantonment areas or barracks and the demobilization of remaining forces, and controlling Bosnian air space" (Burg and Shoup 1999: 377). When the intervention began, there were more than 400,000 Bosnian under arms. Coercive means had diffused to different organizational forms 
and levels: Entity militaries, special forces, police, and larger militias (Bliesemann de Guevara 2009: 186-187). Since the DPA had not been signed by the elites of the Republika Srpska but by the Serbian government, it was unclear how cooperative one of the three warring factions would act.

Compared to most armed groups that operate under conditions of international intervention, the entities (and especially Republika Srpska) had very strong military capabilities. The resulting weaker bargaining position of the international community is reflected in the Dayton agreement. Entities were given the right to entertain their own international relations and they were obliged to "[..] provide a safe and secure environment for all persons in their respective jurisdictions [..]" (UN 1995: 64). The matter of violence is the major contradiction of the Dayton Peace Agreement. On the one hand, the DPA and the international intervention were committed to saving a unified state Bosnia-Herzegovina. Among the stated goals were the (re-)establishment of a central government (with the authority to conduct foreign policy), democracy, and the rule of law. On the other hand, the monopolization of the means of large-scale violence was left out of the DPA. Instead, NATO became the major actor of large-scale violence, keeping in check the two armed factions and brokering institutional arrangements to ease tensions between the entities (Vetschera and Damian 2006: 30-31). In 1997, the agreement on the Bonn Powers for the Office of the High Representative made it clear that statebuilding was the central goal of the interventionists. Eventually, in 1999 the creation of the Common Security Policy Working Group marked the beginning of external attempts to create a monopoly on large-scale violence (Vetschera and Damian 2006: 31).

In summary, the intervention in Bosnia-Herzegovina developed only slowly into a full statebuilding operation. The creation of a monopoly on large-scale violence was seen as a highly contentious issue. Given the military strength of the RS, the goal of unifying the armed factions was only announced after the international community had integrated the Bosniak and Croatian forces. 


\section{The Regional Cooperation Mechanism}

The statebuilding intervention in Bosnia-Herzegovina was one of the longest lasting in history. With an initial deployment of 60,000 troops and a highly intrusive intervention style both by NATO and the EU, it has also been one of the most ambitious. The outcome was a monopoly on large-scale violence, although many problems remain. Bosnia-Herzegovina is not a perfectly sovereign state: As of 2014, there was still a residual force of 600 EU troops deployed. More importantly, the High Representative is still endowed with the Bonn Powers that allow him to veto Bosnian policymaking. Nevertheless, $\mathrm{BiH}$ has a unified army and a national Ministry of Defense, and there are no other national actors who control the means of large-scale violence. As in the case of Sierra Leone, this outcome can be explained only by taking into account the regional context in which the statebuilding efforts took place. Integrating the armed forces of the AFBiH and the VRS became possible because the neighboring states, Croatia and Serbia, proved willing to cooperate with the interveners. Hence, the regional cooperation mechanism can explain the monopolization of large-scale violence in the case of Bosnia-Herzegovina.

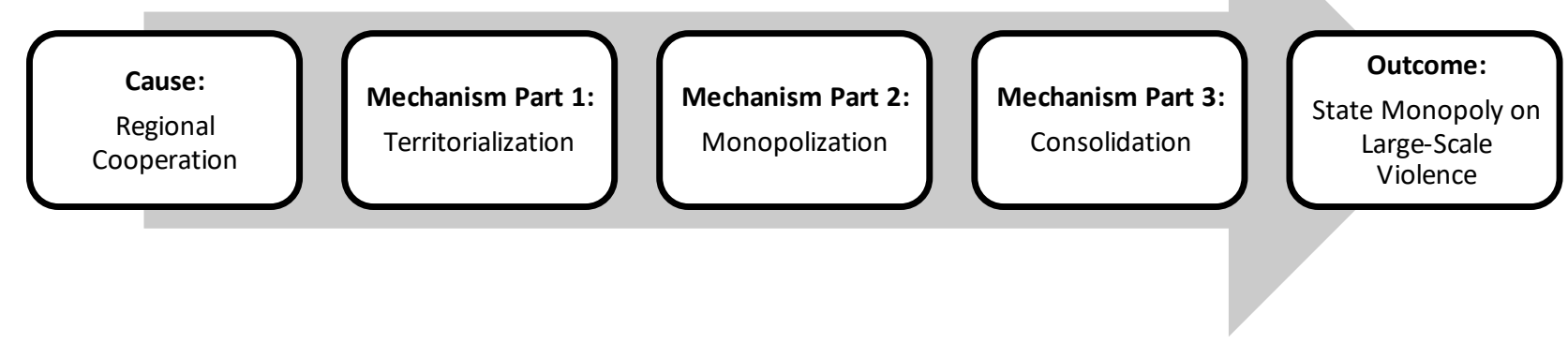

Figure 22: Regional cooperation mechanism.

The mechanism was triggered in Bosnia-Herzegovina by increasingly cooperative behavior of key regional actors. First, Croatia turned towards the EU and eventually became a member state in 2013. Later, Serbia also opened itself for Europeanization and now actively seeks EU membership. Both states are pivotal for the state formation of Bosnia-Herzegovina and have 
experienced a significant transition of their relationships. While in the mid-1990s, both countries saw their environment as hostile and viewed their proxies in Bosnia as necessary tools to enhance their national security, both states experienced dramatic changes beginning in 2000 that eventually redefined their national interest. This change to cooperation made a monopolization of large-scale violence in Bosnia-Herzegovina possible:

(1) Territorialization: The first step of the mechanism entails the territorialization of the conflict. In the case of Bosnia-Herzegovina, the cooperative turn of Croatia and Serbia was accompanied by their official acknowledgment of the borders of $\mathrm{BiH}$. Accordingly, they incrementally reduced their support for the former warring factions of the $\mathrm{FBiH}$ and the RS.

(2) Monopolization: In step two, the means of large-scale violence are monopolized through the statebuilding mission. Without the external support of the neighboring patrons, first the Croats and many years later Republika Srpska are bargained into accepting a unified army.

(3) Consolidation: With the help of the intervener, the government creates a national Ministry of Defense, and eventually builds the Armed Forces of Bosnia and Herzegovina. The army is developed as a professional, affordable force with the main mission of conducting peacekeeping operations.

The outcome of this process was a monopoly on large-scale violence. By 2014, only a small supporting international troop contingent was deployed to Bosnia-Herzegovina. The central government, while weak when it comes to policymaking, controls the unified armed forces of $\mathrm{BiH}$.

\section{Cause: Regional Cooperation}

This section argues that the key regional actors in the case of Bosnia-Herzegovina cooperated with the statebuilding intervention of NATO and the EU. The regional environment of the intervention in Bosnia-Herzegovina has undergone a stark transformation. There are two major dimensions that define the regional context of Bosnia's state formation, civil war, and intervention: First, the Balkans is the close neighborhood of Bosnia-Herzegovina. Second, the 
Balkans itself is embedded into the wider European context. Initially, Bosnia's neighbors Croatia and Serbia found themselves in a competitive constellation and undermined the statebuilding efforts. However, due to changes both in Bosnia's close neighborhood as well as in wider Europe, the regional constellation transformed towards a cooperative environment during the years after civil war. This section will briefly discuss the key regional actors, their preferences and policies.

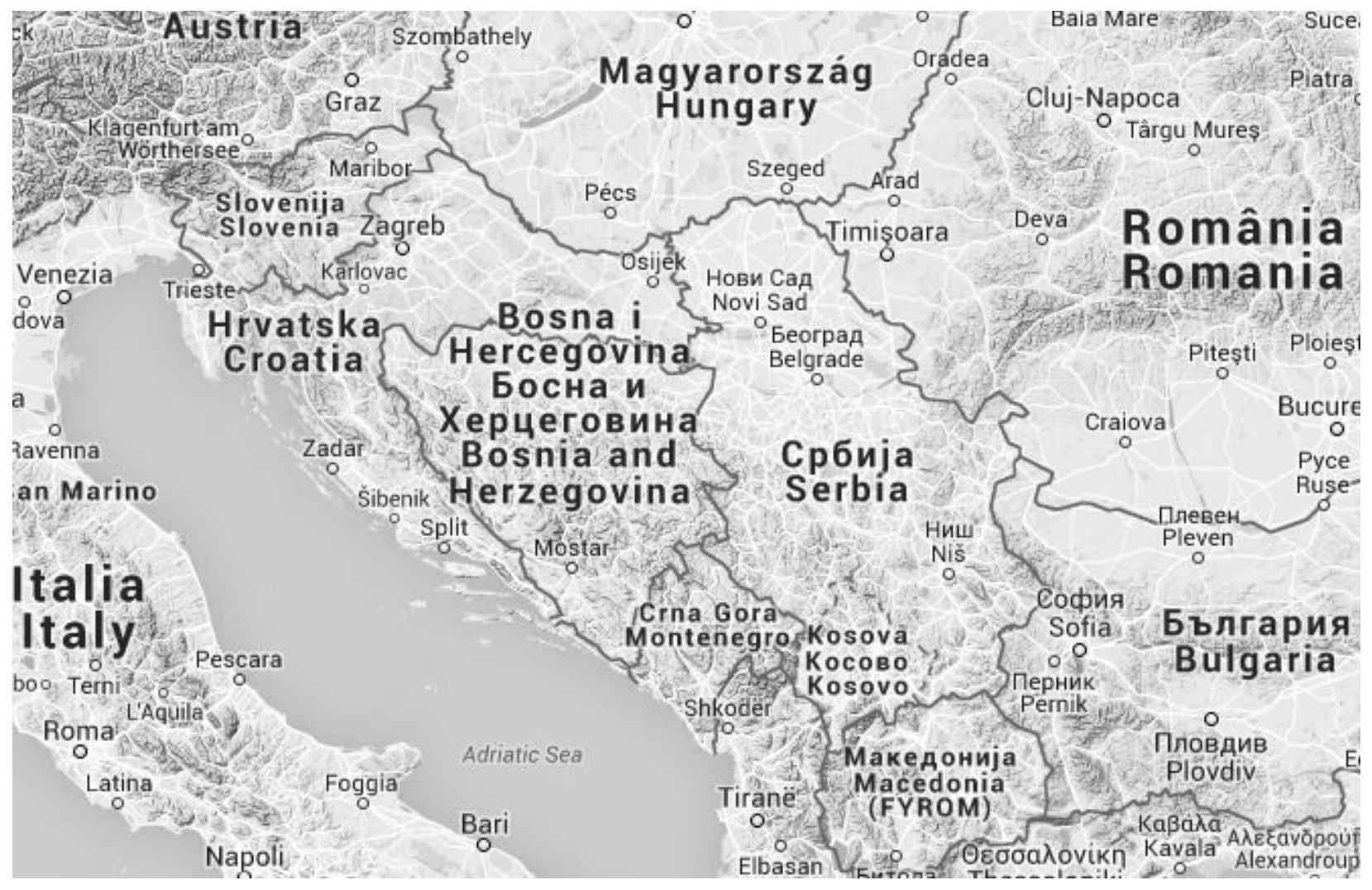

Figure 23: Map of the Western Balkans and its European neighborhood (Google 2014).

After the dissolution of Yugoslavia, BiH had borders with only two neighboring states, Croatia and Serbia-Montenegro. Montenegro eventually seceded from Serbia in 2006. The breakup of SFRY and the subsequent formation of new states meant that the regional constellation changed dramatically. Until 2000, the regional context of the statebuilding effort was informed by the enmity between the former warring factions and states. In order to strengthen their relative positions within the regional constellation, Serbia (FRY) supported the Republika Srpska, while 
Croatia supported Croatian Bosnians. In order to understand the conflictual setting, it is necessary to have a closer look at the positions of the two neighboring states.

The instant international recognition of Bosnia-Herzegovina made it difficult for Serbia to integrate the Republika Srpska into a 'Serb Yugoslavia' as this could have been interpreted as an act of inter-state war. Over time, the gap between the RS elites and the Milošević regime widened. The Serbian leadership had two major goals once it became clear that it could not hold together the old Yugoslav order: Protect its territorial integrity, and protect Serbians across Yugoslavia. Thus, Serbia became heir to Yugoslavia in that it took over many institutions, but lost most of the territory and population to the newly emerging states. The speed with which the old order fell apart made it a priority for Serbian elites to safeguard their territory against any potential alliance against them. Nevertheless, there was a fear in the Serbian leadership that the disintegration of Yugoslavia was part of a Western conspiracy against the Communist regime. This constellation created a foreign policy that was characterized by distrust against Croatia, the EU and NATO (Stroh 2003: 356-357).

Unlike Serbia, Croatia under Tuđman was not the defender of a crumbling order but president of a new state in the international system. From its very inception, Croatia had a closer relation to the European Union as states such as Germany were quick to recognize Croatian independence. In reaction to its secession, there was a brief war between Croatian forces and the JNA. Croatian elites saw the major security threat in attempts by Serbia to use the JNA to create a Serb-dominated Yugoslavia or Greater Serbia. However, the JNA retreated from Croatia already in 1992. The fighting between Croat forces and the Serb minority that lived in the Krajina was more intense. Warfare in the region ended only in 1995 with a Croat victory (Hösch 2008: 281283). Consequently, Croatia was both wary of Serbia as well as the Serbs on its own territory and across the border in Bosnia-Herzegovina. While Croatia was generally susceptible to being part of Europe, Tuđman was not willing to make the wide-ranging reforms that would have been necessary for further integration (Stroh 2003: 357-358).

The conditions in the wider European setting were also not very conducive for statebuilding in Bosnia-Herzegovina. At the onset of the conflict, the European Communities (later European Union) was still mostly confined to Western Europe. Nevertheless, it surrounded the conflict 
zone through Austria in the North, Greece in the South, and Italy across the Adriatic Sea. As mentioned above, individual European countries have partly contributed to the wars by quickly recognizing the independence of the new Balkan states. This undermined the early formation of a unified European stance towards the disintegration of Yugoslavia (Starčević-Srkalović 2010: 112). Initially, the EC made some efforts to mediate in the emerging conflict. However, during the civil war, the UN and NATO were the main international actors intervening in the conflict (Burg and Shoup 1999: 208-211). The crisis made it apparent that the EU lacked mechanisms to formulate common foreign policies and to solve violent conflicts in its neighborhood. Nevertheless, the EU was a signatory of the Dayton Peace Agreement and has since then adopted an ever greater role in the Balkans. Between the end of the war and 1999, the EU increased its footprint in the region through economic assistance, but still remained only a secondary actor in comparison to the US and NATO (Starčević-Srkalović 2010: 114-115). Overall, in the period from 1995 to 2000, Croatia and Serbia were caught in an adversarial relationship. Both states were ruled by war-time elites who viewed Bosnia as a buffer zone between them. While relations were 'normalized' to a certain extent, they would not become friendly in the short term. Instead, the brewing crisis in Kosovo increased tensions between both countries, and by 1998 they were frozen again. The European Union played only a limited role in the regional setup during the decade of war and intervention.

Beginning in 2000, the regional constellation changed dramatically. Two factors were important: First, the war-time elites in both Croatia and Serbia lost their power due to domestic democratization processes. Second, the European Union adopted a new strategy for the Balkans that promised accession to states like Croatia and Serbia if they fulfilled the EU's conditions. In terms of democratization, the year 2000 was a pivotal moment for the Balkans region. Both in Croatia and Serbia, democratic revolutions led to a change in power. War time elites were replaced by elected officials. In Croatia, Tuđman's death in 1999 was followed by national elections in 2000. The nationalist HVO suffered heavy losses, and a center-left coalition formed the new government. In Serbia, protests against Milošević in 2000 led to the formation of a new government (Willenberg 2007: 10). For Croatia, the change in government meant a re-orientation of its foreign relations. Under Tuđman, Croatia had often times adopted isolationist positions and attempted to be neither part of a European nor a Balkan integration process (Jović 2006: 90-92). After the elections, "[ $\mathrm{t}]$ he new narrative was based on the notion that isolation was neither 
desirable nor viable in the long term. In order to survive as a state, Croatia must join European institutions" (Jović 2006: 93). Serbia's shift can be considered even more radical, as its foreign policy was based on the premise that the West is hostile to Serbian interests. ...., this meant a complete overhaul of Serbia's foreign policy, possibly amounting even to a change in national identity. Beginning in 2000, Serbia actively sought participation in the international community and inched closer to the European Union (Stroh 2003: 365-366). Arguably the strongest symbolic act that documents the turn towards Europe was the extradition of former President Milošević to the ICTY.

As a result of this re-orientation, the European Union's power in the region grew significantly. In 2000, the European Union began to offer an accession perspective to the states of the Western Balkans (Stroh 2003: 363). On a broader regional level, the EU vastly expanded eastwards during the 2000s. After the accession of southern European states during the 1980s, the only expansion during the 1990s that had relevance for the Balkans was the accession of Austria. However, between 2004 and 2014, thirteen (mostly Eastern European) countries joined the European Union. Among them were two former Yugoslav republics, Slovenia (2004) and Croatia (2014). Furthermore, with Hungary (2004), Romania, and Bulgaria (2007), direct neighbor states of Serbia joined the union. As a consequence, today the former members of Yugoslavia have been completely drawn into the sphere of influence by the EU. The Balkans have become subject to the EU's external governance mechanisms, particularly through the Stability and Association Process (SAP) which offers the long-term incentive of EU membership (Starčević-Srkalović 2010: 114-116). All former Yugoslav republics are either in the accession process as candidates (Macedonia, Montenegro, Serbia) or potential candidates (Bosnia-Herzegovina, Kosovo), while two states already have acquired membership (Croatia, Slovenia) (EC 2014). While this indicates a growing leverage of the EU over Balkan states' internal affairs, it also implicates that the states of former Yugoslavia have reached a certain consensus about their mutual relations and their place in the regional system.

All these aspects amount to a deep transformation of the regional constellation from a former war zone in which states saw each other as rivals, to a region that is on the verge of completely joining the European Union. The relations of the key regional actors in the case of BosniaHerzegovina have thus become pacified and are characterized by largely cooperative behavior. 


\section{Step One: Territorialization}

This section shows that the capability of the Bosnia-Croat and Bosnian-Serb forces to resist the monopolization of violence strongly depended on the support they received from their patrons, Croatia and Serbia. Once the two neighboring countries started cooperating with the external statebuilders and recognized the territorial integrity of the Bosnia central state, the opponents of monopolization lost their access to transnational spaces. This greatly reduced their bargaining power in relation to the external statebuilders.

The main opponent of the monopolization of large-scale violence in post-war BosniaHerzegovina was Republika Srpska. RS bargaining power resulted from it autonomy which was a direct consequence of Serbia's (FRY's) support: RS had access to the Serbian market, and the SDS nationalist leadership received political and financial support. The most important initial support was the de facto provision of a whole army to Republika Srpska, thereby kick-starting the state formation process (Andreas 2004: 34-35). With the help of the FRY it had access to a real military force early on. After the declaration of independence, the JNA released around 80,000 Bosnian Serbs from its ranks. Additionally, these troops could keep most of their weaponry so that in fact, the FRY consigned the RS a whole army. They would form the core of the new VRS which grew to a force of 100,000 troops by 1994 (Bliesemann de Guevara 2009: 178-179). Financial support was one of the major dimensions of external assistance for the VRS. All of its

officers were on the payroll of the Yugoslav armed forces so that personnel costs were extremely low for the RS (Zahar 2004: 36). The Serb Democratic Party (SDS) in the RS acted as the de facto statebuilder during and after the war, controlling the state apparatus as well as the media (Zahar 2004: 39-41). It is difficult to determine how much autonomy the Republika Srpska had during the war. The ICTY went so far to argue that the FRY controlled the military campaign of the RS. "Such control manifested itself not only in financial, logistical and other assistance and support, but also, and more importantly, in terms of participation in the general direction, coordination and supervision of the activities and operations of the VRS" (ICTY 1999: 69). However, after 1993 Republika Srpska has increasingly developed into an independent polity which was dependent on Serbia, but not completely controlled by it (Zahar 2004: 36). 
The signing of the Dayton Peace Agreement in 1995 was the international recognition that both FBiH and the RS had acquired state-like qualities. They had now clearly demarcated territories in which each of them had a monopoly on large-scale violence. At the same time, the wording 'entity' made clear that there was no international recognition of their statehood, but a commitment to the state Bosnia-Herzegovina as a whole. Nevertheless, the entities were allowed to establish international relations. This meant that the de facto ties to their external patrons, Croatia and Serbia, were legalized. Serbia's foreign policy under Milošević was guided by a strong desire for autonomy, the fear of territorial disintegration, and the belief in Western antiSerbian attitudes and policies. As a consequence, Serbia did not recognize Bosnia-Herzegovina as a sovereign state (Willenberg 2007: 9-10). Besides the NATO occupation of BiH, the Serb elites had two major grievances with Sarajevo. The first was the fact that $\mathrm{BiH}$ was suing the FRY at the ICJ for its involvement in the war crimes committed during the civil war. Milošević wanted these charges to be dropped. The second point was a more general issue, namely the demand that $\mathrm{BiH}$ should accept that the FRY was the sole successor of the SFRY (Stroh 2003: 361-362). While keeping its distance to the central government in Sarajevo, the FRY entertained very close relationships with Republika Srpska. The strong ties with Yugoslavia allowed RS to trade freely with its close neighbor, thereby making it economically independent of the central state. Thus, by 1999 "[..] 43\% of all imports came from FRY, while 75\% of all exports went into FRY" (ICG 1999: 10). In addition, companies were part of a highly interdependent network across the border, and critical infrastructure such as power supplies were shared between RS and FRY (ICG 1999: 10-11). Furthermore, FRY actively undermined the state of $\mathrm{BiH}$ by supporting radically nationalist forces in RS. This further contributed to the deadlock at the national level and secured FRY's influence in RS (Stroh 2003: 362).

The Bosnian Croats also depended on support by the Croat state, but they were militarily weaker and politically less radical than RS. Hence, they were the lesser obstacle to the monopolization of large-scale violence. At the beginning of the conflict, the government of Bosnia-Herzegovina was ethnically mixed but militarily weak. During the course of the war the situation changed. Under Izebtbegovic' leadership, the government side became almost purely Bosniak, while the loosening up of the international arms embargo improved the government's military capacities (Bliesemann de Guevara 2009: 180). At the same time, Croatia was actively arming the Croat Bosnians. Furthermore, it was for several years an active participant in the 
conflict (ICTY 1996). As a result, the Croat HVO could command up to 45,000 soldiers (Bliesemann de Guevara 2009: 179-180). After years of brutal fighting and ethnic cleansing between Bosniaks and Croats, the two sides decided to join forces due to political pressure by the US and military pressure by the RS. Therefore, by 1994 the war had reached a very symmetric constellation (Christia 2012: 162-164). The formation of the Federation of Bosnia-I Herzegovina turned the chaotic three-side-war into a more clearly structured conflict. Whereas the $\mathrm{FBiH}$ represented about $2 / 3$ of the $\mathrm{BiH}$ population, the RS only represented 1/3 of it. However, the RS's armed forces continued to be the most effective force in the conflict. At the same time, the international intervention increasingly supported the $\mathrm{FBiH}$ side, thereby allowing it to form better resourced armed forces (Christia 2012: 165). While Croatia had recognized $\mathrm{BiH}$ in 1992, it continued to undermine the central government by financially supporting its Croat proxies and, to some extent, the FBiH government. These relations were institutionalized in 1998 when Croatia signed a special relations agreement with the Federation (Stroh 2003: 360-361). The support of Serbia and Croatia thus strengthened the individual entities. While the FBiH, and especially the Bosniaks, had a great interest in stronger national integration and the creation of a monopoly on violence, the RS strongly opposed such effort.

The change in the regional relations from competitive to cooperative had a great effect on the autonomy of the entities vis-à-vis the external actors. Directly after its revolution, Serbia (FRY) started formal relationships with $\mathrm{BiH}$ in 2000. It opened embassies and institutionalized cooperation, but it also went further by addressing sensitive issues. Most importantly, FRY's foreign minister Svilanociv acknowledged the aggressive character of SFRY's policy towards Croatia and $\mathrm{BiH}$. The President followed in 2003 by apologizing to the Bosnian people for Serbia's/SFRY's actions during the war (Willenberg 2007: 10). Economic decoupling was greatly accelerated by the NATO war on Kosovo, in which important connections were disrupted. "NATO bombing has all but destroyed economic ties between the FRY and Republika Srpska" (Zahar 2004: 47). After 2000, these connections were not brought back to the state quo ante. The share of imports to the Republika Srpsa originating in Serbia has continually decreased over the recent two decades, and the RS' trading relations have diversified (IRBRS 2014). This indicates a development away from a patron-client relation to one in which trade occurs with many states who have relations with the central government instead of the RS. Nevertheless, Serbia's relationship with Bosnia did not change in an instant, and the process of recognition was 
punctuated by periods of disengagement. In 2002, it signed a special relations agreement with the RS although Croatia had already cancelled its special relations to the $\mathrm{FBiH}$ in 2000 (Willenberg 2007: 11). However, the long-term trend of Croatia and Serbia being increasingly integrated into the European Union makes a relapse into a conflict-prone regional constellation unlikely. In 2014, Serbia's new government has signaled that it deems the federal government of $\mathrm{BiH}$ the legitimate addressee of its foreign policy. Serbian PM Vucic chose Sarajevo as his first foreign destination, and he has clearly articulated Serbia's commitment to a united Bosnia-Herzegovina (Reuters 2014b).

Overall, BiH's key neighbor states have developed a consensus on their foreign policy which includes the acceptance of a sovereign Bosnia-Herzegovina and a strong reduction in special relations to the individual entities. To a large extent, this process is driven by a desire of the political elites to join the European Union.

\section{Step Two: Monopolization}

Once the conflict had lost its transnational character, the statebuilding intervention could engage in a successful monopolization process. This section shows how first the Croat and Bosniak forces were integrated, and how eventually Republika Srpska was bargained into accepting a merger of the two entity armies.

At the time the DPA was signed and SFOR took shape, Bosnia-Herzegovina was a completely militarized society. Although the country has a population of barely four million, over 400,000 men were under arms in 1995. This included somewhere between 175,000 and 227,000 regular soldiers in the three armies as well as militias across the country (Bliesemann de Guevara 2009: 186). However, disarmament in $\mathrm{BiH}$ did not entail disarmament of entities in favor of a state monopoly on violence. Instead, the entities remained capable of waging large-scale violence, albeit with significantly reduced forces (UN 1995: 64). When the interveners began first to engage with the security sector in Bosnia-Herzegovina, the situation was very complex: "In 1996, the concept of unifying the recently belligerent armies into a single command and control structure, radically shrinking the active-duty force to 10,000 , and ending conscription was inconceivable" (Azinović et al. 2011:31). 
Beginning in 1996, the first step of monopolization in Bosnia-Herzegovina was a US program named Train and Equip. Under this program, the US and several allies pledged to invest 400 Million Dollars in the strengthening of the Army of the Federation of Bosnia-Herzegovina. This program had two major intentions: First, the US deemed it necessary to create a balance of power within $\mathrm{BiH}$ between the two entities in order to make offensive action on part of the RS less likely. Second, the armed forces of the federation were split into a Bosniak and a Croatian force. In order to build functioning institutions, $\mathrm{FBiH}$ was supposed to build Armed Forces of the Federation (Burg and Shoup 1999: 379-380). While the program succeeded in making the Bosniaks the militarily strongest group in Bosnia-Herzegovina, the integration of the HVO into the federation remained a formality. In practice, the armies continued to exist as separate forces with their own chains of command, even though a common ministry of defense was established (Pietz 2006: 161-162). HVO troops also kept the Croat areas under its control (Boyle 2014: 116). Nevertheless, the professionalization, resutructuring and equipping of the two forces reduced frictions and made eventual integration into a Bosnian army easier (Pietz 2006: 162). Hence, while efforts to integrate Bosnia-Croat and Bosniak forces did not fully succeed, they paved the way for a future unified army.

With a lack of sponsoring from their external patrons, both the Croats and the Serbs found it increasingly difficult to fund their over-sized armed forces and patronage-networks that were supported through the military (Bliesemann de Guevara 2009: 195; 208-210). In RS, moderate elites became more influential as the war-time elites that had depended on Serb support had been weakened (Berg 2014: 156). At the same time, the European Union and NATO could offer rewards for Bosnian cooperation: The long-term prospect of EU accession as well as the shortterm establishment of a Partnership for Peace between BiH and NATO. Therefore, NATO formulated the creation of a national $\mathrm{MoD}$ and a unified armed force as a condition for entering the Partnership for Peace (Berg 2014: 156). The RS slowly softened up its position and agreed to the creation of a national MoD without a unified army in August 2002 (Bliesemann de Guevara 2009: 208). However, an arms trade scandal in 2003 eventually created a window of opportunity for the external actors to exploit the split of the Bosnian-Serb elite (Morton 2012: 519-520). It had become public that military elites of the RS were selling weapons to Iraq amid the US preparations for war against the regime of Saddam Hussein. The following international outrage and the discrediting of the old security establishment strengthened were utilized by those political 
actors in RS who preferred a centralization of armed forces. When Mirko Sarovic, head of the SDS party, had to resign in the wake of the arms scandal, his party colleague and President of the RS Dragan Cavic took his position and became one of the leading figures of the monopolization effort.

In a dramatic speech to a special session of the RS National Assembly, Cavic accused senior army officers of greater loyalty to Belgrade than to Banja Luka, saying 'it is time for the Serb Republic Army officers to realize that their fate is here in the Serb Republic' (Berg 2014: 156)

In May 2003, the Defence Reform Commission (DRC) was created in order to organize the merger of the two armed forces present in BiH. Subsequently, the Bosnian parliament issued a law that established a national Ministry of Defense in late 2003, and the ministry began its work in 2004 (Bliesemann de Guevara 2009: 202). Finally, in 2005 the parties agreed to merge the armies on 1 January 2006 (NATO 2014).

To sum up, once the minorities had lost their access to transnational support, nationalists were weakened. As a result, it was possible for the statebuilders to merge the armed forces of all three groups, an outcome that had seemed impossible during the 1990s.

\section{Step Three: Consolidation}

After the co-existing armed groups were merged into one national army, the consolidation of the monopoly could occur. In the process, the institutional structure of the monopoly on large-scale violence was created, the armed forces were professionalized and they were reduced to a sustainable size.

The creation of a national Ministry of Defense and of the Armed Forces of BosniaHerzegovina $(\mathrm{AFBiH})$ was a milestone of the statebuilding effort. Whereas at the beginning of the 2000s it was seen as almost impossible to create unified national forces, during the bargaining process a 'minimally centralized' armed force was seen as a likely outcome. However, by 2006 "[the] new AFBiH consisted of a Ministry of Defence with full authority in defense matters and a Joint Staff with full command of all military elements" (Maxwell 2014: 181). A national ministry was of great importance in order to ensure centralized political oversight over the army. Within 
the army, and unlike in the case of the Armed Forces of the Federation of Bosnia and Herzeogvina, the AFBiH had no parallel command chains (Maxwell 2014: 188).

Another center piece of the consolidation process was also the abolition of conscription, which so far had provided the entities with abundant personnel resources. Cancelling conscription made it possible to further reduce the armed forces of all sides and further professionalize the army: "The overall force for all entities has been reduced from a post-Dayton high of somewhere between 175,000-225,000 personnel to its current level around 10,000” (Morton 2012: 521). Reserve forces, which would have allowed a massive mobilization in case of open conflict, were reduced from 60,000 troops to a level of 5,000 (Maxwell 2014: 180). In order to ease inter-ethnic tensions and power politics within the armed forces, the recruitment procedures of the $\mathrm{AFBiH}$ are guided by ethnic quotas. In 2011, the armed forces consisted of 46\% Bosniaks, 34\% Serbis, and 20\% Croats (Azinović et al. 2011:31).

A major pillar of the consolidation of the monopoly on large-scale violence was giving the armed forces a new identity. It was problematic to build this identity around national defense, as $\mathrm{BiH}$ is surrounded by friendly neighboring states. Furthermore, the Balkan region enjoys a 'security umbrella' because it is surrounded by EU and NATO members. Therefore, the new role of the army had to differ markedly from the former JNA as well as from those of the entity forces during the war. Thus, the focal point of the new identity became integration into NATO (Maxwell 2014: 198-190). The modern AFBiH are not meant to operate autonomously or protect $\mathrm{BiH}$ against its neighbors, but to strengthen inter-operability and to eventually fully integrate into NATO structures (Maxwell 2014: 189-190). The Bosnia government applied to NATO's Partnership for Peace program in 2006, and has since pursued a full NATO membership. In 2010, the country joined the Membership Action Plan, and as of 2014 only few obstacles remain to becoming a NATO member. Specifically, the Repulika Srpska still controls army bases and other fixed military sites on its territory. NATO has made it a requirement for BiH's accession that the central government has to have control over these sites (NATO 2014). Nevertheless, the AFBiH have been developed into a deployable force that has participated in peacekeeping missions (Bliesemann de Guevara 2009: 214-217). The first operation of the newly established army was a mission to Iraq that began already in 2005, where Bosnian forces focused on clearing mines and guarding bases. In 2009, Bosnia-Herzegovina also deployed troops Afghanistan where the Bosnian also guarded allied bases (Brljavac 2012: 33-34). Although both missions only entailed 
small units of a few dozen soldiers, they clearly signaled BiH's commitment to becoming part of the Euro-Atlantic security community.

Overall, the newly established monopoly on large-scale violence was consolidated through reforms both of the institutional frame and the inner workings of the armed forces. As in the case of Sierra Leone, the process could succeed because there was no violent resistance to the monopolization process.

\section{Outcome: State Monopoly on Large-Scale Violence Regulation}

The statebuilding intervention in Bosnia-Herzegovina has succeeded in creating a monopoly on large-scale violence. The central government features a Ministry of Defense which oversees the unified Armed Forces of $\mathrm{BiH}$, and there are no more armed groups on the state's territory. The state is in the process of joining NATO, although some minor obstacles remain. Critics of the intervention will view this assessment with great skepticism, as Bosnia-Herzegovina is still not a sovereign state. The High Representative still has wide-ranging powers over Bosnian politics, although the role of international actors has become much less pronounced than in the early stages of intervention. A residual force of 600 EUFOR troops remains stationed in the country.

However, two aspects need to be considered: The first is the fact that a monopoly on large-scale violence is a minimal condition of statehood. It does not indicate that the whole statebuilding effort was successful, but only that one necessary condition for stable statehood has been established. Second, the creation of a unified army was seen as utopian in the early days of intervention. For four years, the armed faction had committed grave atrocities against each other and against civilians of different ethnicity. The fact that Bosnia-Herzegovina today has a national army that participates in peacekeeping missions is a milestone on its way to lasting pacification. If the modest benchmark of regulating large-scale violence is applied, Bosnia must be seen as a successful case. 


\subsection{Statebuilding Intervention and Small-Scale Violence Regulation}

In the case of Bosnia-Herzegovina, the statebuilding intervention succeeded in creating a state monopoly on the regulation of small scale violence. This section argues that this success can only be explained by taking into account the long-term state formation of Bosnia-Herzegovina. Put differently, the cause for success far preceded the intervention. Before presenting the causal mechanism in detail, this section will first introduce the measures taken by the international statebuilders to build a state monopoly on small-scale violence regulation.

In order to achieve their goal of establishing a liberal state in Bosnia-Herzegovina, the international actors needed to establish a state monopoly on small-scale violence regulation. Two main means to arrive at that end: First, the intervention shaped the formal institutional setting which was supposed to regulate small-scale violence, and second, the intervener supported the government materially through training and equipping the police force.

At the broader institutional level, UN and NATO greatly shaped the post-conflict order by brokering the Dayton Peace Agreement (DPA). The DPA has since worked as a constitution for Bosnia, and thus also included the basic structures according to which the regulation of smallscale violence would occur in the post-war society. In article I, the document clearly states that the state "[..] shall operate under the rule of law and with free and democratic elections" (UN 1995: 60). The entities were assigned the task of law enforcement:

The Entities shall provide a safe and secure environment for all persons in their respective jurisdictions, by maintaining civilian law enforcement agencies operating in accordance with internationally recognized standards and with respect for the internationally recognized human rights and fundamental freedoms. (UN 1995: 64)

At the operational level, the intervention in $\mathrm{BiH}$ encompassed one of the most resourceintensive policebuilding missions ever conducted in statebuilding missions. The International Police Task Force (IPTF) was established through the DPA in 1995 (UN 1995: Annex 11, Art. IIII). Initially tasked with monitoring the native police force, it's mandate was later expanded to include training, restructuring and vetting. IPTF encompassed the deployment of 1,721 international police monitors who were deployed to 54 police sites across the Federation 
(Dziedzic and Blair 1998: 272-273). In 1998, the program was expanded to Republika Srpska, and the mandate was strengthened. IPTF acquired the ability to 'de-certify' police officers who had been involved in human rights violations during the civil war, and the focus shifted to a promotion of democratic policing (ICG 2002a: 7). In 2003, the UN-led IPTF was replaced by the European Union Police Mission in Bosnia and Herzegovina (EUPM). EUPM had less personnel and a weaker mandate than IPTF. Instead of de-certifying Bosnian police officers it could only suggest individuals to the OHR who could then dismiss them from service. Its main focus was on the restructuring of the police organization in Bosnia Herzegovina (Muehlmann 2008: 4-6).

To sum up, the means of the intervention in Bosnia-Herzegovina to monopolize the regulation of small-scale violence were typical for liberal statebuilding. The next section applies the strong state legacy mechanism to the case of Bosnia-Herzegovina, arguing that the statebuilding success with regard to small-scale violence regulation can be explained by the country's long-term state formation.

\section{The Strong State Legacy Mechanism}

The argument of this section is that Bosnia-Herzegovina's history of strong statehood prior to the civil war has caused the statebuilding intervention to succeed in monopolizing the regulation of small-scale violence. This clearly distinguished Bosnia from post-colonial cases like Afghanistan or Sierra Leone. The UN and NATO were successful in re-establishing a state-centered order in which police and justice regulate small-scale violence. This outcome was made possible by the fact that Bosnia-Herzegovina has a history of strong statehood, even though it has not been an independent state prior to the collapse of Yugoslavia. Thus, despite the emergence of militias and the politicization of police forces, there were no more survival units in BiH. People had been socialized into a state-centered order during decades of socialist statebuilding. Consequently, state police did not encounter non-state competitors and could be reformed along the lines of democratic policing and the rule of law. 


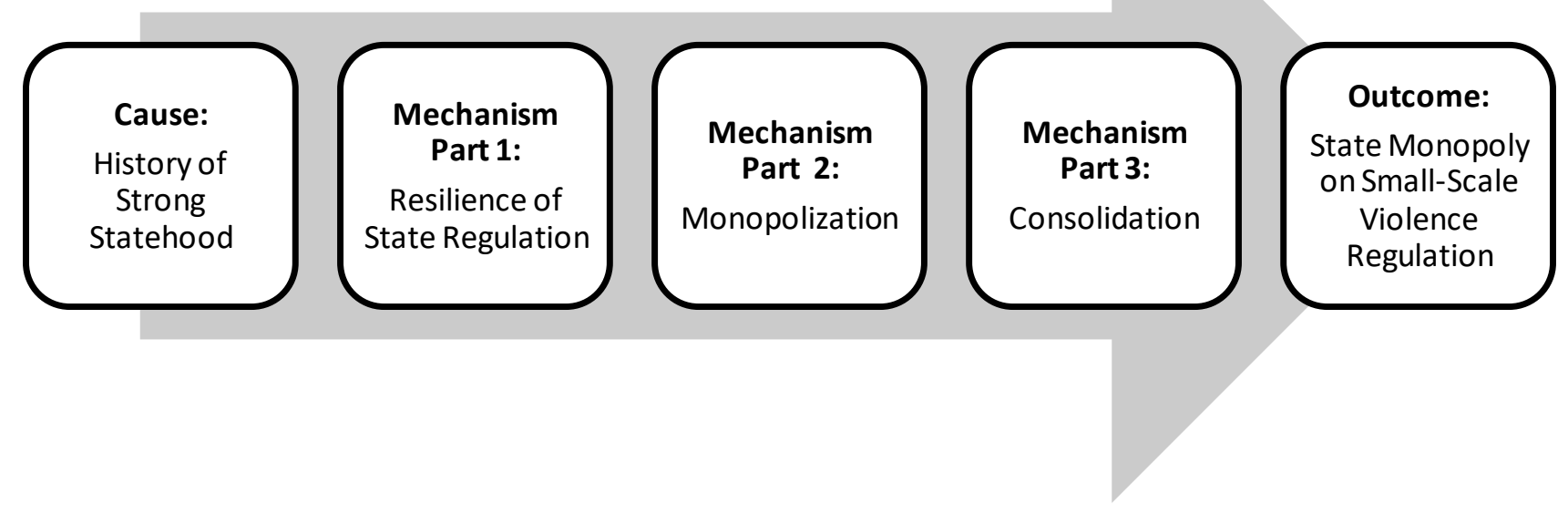

Figure 24: Strong State Legacy Mechanism.

The causal mechanism is triggered by a remote cause, namely the long term state formation that had occurred in Bosnia-Herzegovina since the $19^{\text {th }}$ century. Both the Ottomans and the Habsburger have laid the foundation for a monopolization of small-scale violence regulation through their administrative reforms. After the incremental weakening of local elite throughout the long $19^{\text {th }}$ century, the Kingdom of Yugoslavia and later the Socialist Republic could expand state control to the local level across the territory. Thus, Bosnia-Herzegovina had a state monopoly on the regulation of small-scale violence prior to its declaration of independence and the beginning of the war. This remote cause triggered the causal chain that explains the outcome of the statebuilding intervention.

(1) Resilience: The outbreak of the war led to a fragmentation of small-scale violence actors. Militias, local self-defense groups, hooligans, and criminal gangs proliferated throughout the country. However, state policing only fragmented along the lines of the major armed factions and stayed in place throughout the war. The only small-scale violence regulation that remained firmly institutionalized was the state-centered one (i.e. the Yugoslav legal order and formal policing).

(2) Monopolization: Once the intervention began, the militias could quickly be disarmed. Since these small-scale violence actors were not part of self-help communities but rather 
ad hoc groups, they had little legitimacy with the population and lost their purpose at the end of the war.

(3) Consolidation: Without strong local non-state institutions, the interveners could conduct SSR measures and rebuild the state police forces according to principles of the rule of law and democratic policing. While rule-making occurs at all levels of governance, control over police forces remains at the entity level.

The outcome is a state monopoly on the regulation of small-scale violence. There are no self-help communities in Bosnia-Herzegovina, and the expectation of the population is that the state should make and enforce rules. This is independent from the question of whether the state is Yugoslavia, Bosnia-Herzegovina or one of the two entities. The strongly federalized policing system in $\mathrm{BiH}$ does not contradict the fact that only state institutions regulate small-scale violence. Beginning with a discussion of the evolution of small-scale violence regulation during state formation in Bosnia-Herzegovina, the following section wills process-trace the proposed mechanism in detail.

\section{Cause: History of Strong Statehood}

Bosnia-Herzegovina has not been a sovereign state since the Middle Ages, and only regained its independence in 1991. Nevertheless, it has been subjected to several centuries of state formation during Ottoman, Habsburg, and Socialist rule. In the process, self-help communities have been dissolved and local elites either disappeared or were incorporated into the state. As a result, the state was the only regulator of small-scale violence prior to the outbreak of the civil war.

Until the mid- $19^{\text {th }}$ century, small-scale violence regulation on the Balkans outside the cities was in the hand of self-help communities. Whereas the Ottoman authorities controlled the cities, around $95 \%$ of the population worked in agriculture and were thus located in rural areas. Over several centuries, the Ottomans had sustained a feudal regime in which the ruling class of the Empire, Muslims, would be allowed to own land. These landowners were called Agas and Begs $^{30}$, and they resembled the nobility of Western Europe. Agas and Begs controlled means of small-violence, and in some cases they could mobilize enough men to operate at the large-scale violence level (and thereby threatened central authorities) (Jelavich and Jelavich 2000: 13). The

\footnotetext{
${ }^{30}$ The begs were superior to the agas.
} 
regulation of small-scale violence was further localized by the fact that the (mostly) Christian peasants had their own chiefs. „The Serbs were organized in extended family units, the zadruga. A group of families would elect a representative to the knežina, a kind of district council that in turn elected the knez or chieftain. The knez dealt with the landlords and Ottoman administrators" (Glenny 2012: 7). These chiefdoms had some autonomy as their central obligation was to handover taxes to the Ottoman Muslim elite.

As in current developing countries, the chiefs of Bosnia-Herzegovina managed from time to time to build coalitions and act on the level of large-scale violence. One example is the crisis that shook the Ottoman Balkans at the beginning of the $19^{\text {th }}$ century, during which the knez mobilized up to 30,000 fighters who first fought with and alter against the central authorities (Glenny 2012: 11-16). To sum up, small-scale violence in Bosnia-Herzegovina was mostly regulated by local self-help communities until the mid- $19^{\text {th }}$ century.

The decline of this decentralized form of small-scale violence regulation set in when the Ottoman Empire embarked on an ambitious set of reforms called Tanzimat. First announced in 1839, the Ottoman rulers tried to monopolize the regulation of small-scale violence in Bosnia-Herzegovina from 1850 on. The landowning Muslim elite saw this centralization as a direct threat, and the result were two years of civil war in which the Ottomans were eventually victorious. However, the reforms failed to establish a centralized system of taxation and a system of military conscription. Thus, shortly after the Ottoman commander Omer Paša left Bosnia, "[..] the tax farmers were back in the fields gathering their lucrative harvest while the chief families reestablished themselves and once more refused to send their contingents to the Bosnian army" (Glenny 2012: 83). Such pushes for bureaucratization implied a replacement of traditional elites with professionals who had received training and who would be selected on the base of merit.

After the revolts of 1875, Bosnia and Herzegovina was occupied by Austria-Hungary in 1878. "Habsburg rule shared one feature with the late Ottoman regime that provoked antagonism. Both empires sought to modernize tax collection, military service, and education by bringing them under central control" (Lampe 2000: 65). Bureaucratization was drastically accelerated after the resistance against centralization had been crushed by 268,000 Austrian troops (Glenny 2012: 160-163). Subsequently, the Austrian Joint Minister of Finance for Bosnia, Benjámin von Kállay, 
began to introduce a modern bureaucracy. The number of professional bureaucrats grew from around 100 to over 9,000 within three decades (Glenny 2012: 268). Furthermore, around 1900 Bosnia also experienced a massive expansion of infrastructure and the spread of state schools (Malešević 2012: 311-312). The thrust for formalization, measurement and control affected all areas of society, but the Austrians did not dare to abolish the serfdom of the Serb peasants (Lampe 2000: 57). Overall, while the two Empires failed to overcome local self-help communities, they had severely weakened local elites through a century of constant monopolization efforts. The Empires had unwillingly laid the groundwork for the centralization in the future Yugoslav state.

The next two critical junctures of state formation came in the form of two world wars. Both brought immense destruction for the Balkans, but their cataclysmic effects also created opportunities for political reform. The Kingdom of Serbs, Croats and Slovenes that was officially constituted in 1921 embarked on several reforms that would increase state control over the regulation of small-scale vioelnce. Bosnia-Herzegovina was re-structured into four administrative units (oblasti) (Lampe 2000: 133). In a sweeping land reform, the rural elites were largely expropriated. They received compensations and mostly migrated into an urban bourgeois milieu (Allcock 2000: 179-181).

As one of the previous sections has shown, state formation in Bosnia-Herzegovina accelerated during the rule of the Habsburg Empire and, later, Yugoslavia. For the direct effects of the civil war and the UN intervention, the experience of the Socialist Federal Republic of Yugoslavia was certainly the most relevant period. After the Germans were defeated, Tito officially installed a 'people's government' in April 1945, and Bosnia became a republic of the new SFRY. The socialist statebuilding endeavor in Eastern Europe was strongly shaped by the state's desire to completely monopolize any form of violence and to monitor the population in order to suppress dissent. Unlike many current autocratic regimes in the developing world, many socialist rulers were able to use their party apparatuses to build strong state institutions.

As in Western Europe since the $19^{\text {th }}$ century, people were disciplined by several state institutions. An important tool to 'create citizens' who bought into a state-centered order was conscription. The conscripts would not only learn to defend their country against outside threats, 
but also spend time with people of different ethnicity in varying areas of the republic. Furthermore, the strong Yugoslav state expanded the education system so that ever more citizens were socialized in state institutions (Hösch 2008: 260-261). At the same time, the last set of nonstate laws that had remained in society was abandoned by the state in 1946, when Sharia courts which regulated civil affairs in the Muslim population were banned (Krech 1997: 26).

Under socialist rule, $\mathrm{BiH}$ experienced rapid urbanization. After being designated as an underdeveloped region by the central government in 1958, an emphasis was put on industrialization. Bosnia saw an increase especially in mining and basic metal processing during the post war era. Thus, from the 1970s on Bosnia "[..] has undergone significant industrialization; the urban population tripled, while the agricultural population declined from 60 to only 20 percent" (Filice et al. 1994: 428). The movement of large portions of the population into cities has further increased the capability of the state to monitor its citizens and subject them to its institutions.

Unlike in many Western democracies, policing in SFRY was a heavily top-down operation. While all police forces secure the ruling regime to a certain degree, this aspect was at the forefront of socialist policing. Additionally to regular police forces, the regime created a secret police, the State Security Administration (SDB). SDB centrally controlled six sub-organizations which were responsible for each of the federal republics. Secret polices allowed socialist states to detect and deter the emergence of armed organizations which could have developed into threats for the regime. As such, they were an integral part of the monopoly on violence.

State formation in the SFRY was not only driven by socialist ideology, but also through a competitive regional security complex. Surrounded by NATO and the USSR, Yugoslavia was a neutral state that feared attacks from both blocks. Especially after the Soviet Union cracked down on the uprising in Czechoslovakia, a state-making was fostered in order to strengthen the regimes ability to deter any potential aggressor. Yugoslavia built up its own arms industry in order to reduce external dependencies (Krech 1997: 25). Society was militarized through the principle of Territorial Defense, which envisioned a total (asymmetric) war against invading enemies (Bliesemann de Guevara 2009: 176-177).

To sum up, the state was the only institution in Bosnia-Herzegovina that was able to make and enforce rules. There were no more self-help communities as in the cases of Afghanistan or 
Sierra Leone. When the country declared independence from Yugoslavia in 1991 and civil war erupted, these legacies of long-term state formation proved to be highly resilient.

\section{Step One: State Resilience}

As shown above, small-scale violence Bosnia-Herzegovina was exclusively regulated by the state at the outset of the civil war. While this order partly collapsed during the war, new small-scale violence actors failed to institutionalize self-help communities. Both the legal structures as well as formal policing showed strong resilience in the face of violent conflict.

The onset of the civil war led to a proliferation of means of violence across the territory. Due to the militarization of society under Socialist rule, it was easy for the warring factions to set up militias at the local level. Militias also played a central role both in defending local communities as well as in offensive acts of ethnic cleansing. Across the territory of $\mathrm{BiH}$, up to forty-five armed groups were actively engaged in the conflict (Bliesemann de Guevara 2009: 180-182). Some of the local actors were able to provide peace among the local population. Local JNA commanders or members of the administration sometimes tried to save multi-ethnic communities from falling apart. However, these arrangements could rarely be sustained as violence would spread once a town was conquered by one of the major armed groups (Burg and Shoup 1999: 129-130). Furthermore, the major armed actors used 'special units' which could take the form of anything across the continuum from Special Forces to local militias. These special units such as the Croat HOS, the Muslim Black Swans, or the Serb Arkan's Tigers were strongly involved in war crimes and ethnic cleansing. In Sarajevo, criminal gangs would organize early defenses against the Serb VRS until the government could build up its own capacities (Burg and Shoup 1999). Although militias played a central role during the conflict, they did not reach the status of self-help communities. Local communities did not redevelop the self-help communities that dominated the country until the beginning of the $20^{\text {th }}$ century. Instead, militias in Bosnia-Herzegovina were ad hoc groups that were mostly armed by the major conflict parties. They did not develop their own legal systems nor did they great autonomy vis-à-vis the largescale violence actors. 
Despite this spread of militias, formal police forces remained active during the conflict. The two-tier structure of the Yugoslav police consisted of the municipal police and the Ministry of Interior Special Police (Ministarstvo Unutrašnjih Poslova, MUP). MUPs were paramilitary police forces that could best be characterized as organizations that the government could utilize as either large-scale or small-scale violence actors. This dual-use logic was also institutionally enshrined; for example, the Bosniak MUPs would be controlled by the MoI as long as they were supposed to maintain or restore public order, but they control would switch to the MoD when there was the need to mobilize troops (Dziedzic and Blair 1998: 263-265). Due to the top-down approach of policing in Yugoslavia where the police was integrated into military chains of command, the police forces could easily be used effectively as an offensive tool (Padurariu 2014: 2). When the Yugoslav order collapsed, each of the ethnic groups maintained both their police forces and their MUPs (ICG 2005: 2). One effect of the ethnic conflict was a strong politicization of the police forces.

Thus, they were often involved in ethnic cleansing and other human rights abuses (ICG 2005: 2). During the war, the number of police officers expanded drastically, and an overall trend of para-militarization could be observed. At the end of the war, the small country was divided among three factions that had amassed 44,750 formal police officers: 29,750 in the Bosniakcontrolled areas, 3,000 in Croat-controlled areas, and 12,000 in the Republika Srpska (Dziedzic and Blair 1998: 264). This trend of police expansion stands in stark contrast to the cases of Afghanistan and Sierra Leone, where formal policing was reduced to major cities or had ceased completely after years of civil war. Correspondingly, the legal system of the Yugoslav era remained in place not only during the war but also well into the intervention period (Dziedzic and Blair 1998: 290). This evidence shows that the state collapse in Bosnia-Herzegovina was first and foremost the collapse of the central state and its monopoly on large-scale violence. Where one of the ethnic factions controlled a territory, state law and state police continued to regulate smallscale violence, although the spread of militias created new armed actors who could interfere with this order.

In sum, despite a strong proliferation of militias across the country, the civil war in BosniaHerzegovina has not led to a spread of self-help communities. Instead, local groups were set up and armed in an ad hoc style, police forces remained in place across the territory, and the war 
itself was too short to change the expectations of the population that the state is the only legitimate institution to regulate small-scale violence.

\section{Step Two: Monopolization}

The statebuilding intervention that ended the civil war also succeeded in monopolizing smallscale violence regulation. Without the existence of self-help communities, armed non-state actors lacked the power base to resist monopolization efforts of the state. Thus, even without an orderly DDR scheme, the disarmament of local actors can be regarded as a quick success in BosniaHerzegovina.

The disarmament process in Bosnia-Herzegovina was initially mostly limited to smallscale violence actors, because the entities were officially recognized by the DPA and were allowed to retain their armed forces (Morton 2012: 517). Since Bosnia's society had been highly militarized before and throughout the war, SFOR's task still amounted to a very challenging disarmament campaign. Hence, given the experiences with DDR programs in many weak states in Africa and Asia, one could have reasonably predicted that the proliferation of arms, a culture of violence, and the weakening of the state had created local actors that would successfully resist international statebuilding efforts. The fact that there was no sophisticated DDR program only adds to this expectation (Dziedzic and Blair 1998: 270-271).

About half the up to 430,000 armed persons in the country were not regular soldiers of the armed factions. Instead, they were members of all kinds of groups that could be broadly summarized under header 'militias'. Disarmament of the militias mostly occurred even without much input from the interveners, let alone an orderly DDR scheme. Instead, about 300,000 combatants, both soldiers and militiamen, almost instantly laid down their weapons after the DPA (Bliesemann de Guevara 2009: 186-187). As NATO's emphasis on statebuilding (as opposed to peacekeeping) grew, the disarmament effort was expanded. Disarmament increasingly did not only affect semi-autonomous local militias, but it also affected the small-scale violence capacities of the major conflict parties which still held on to their special police units. "For some 18 months, MUPs in the RS flouted Dayton by carrying long-barreled rifles, grenades, and other weapons and acting as a local enforcement arm of the RS government and the Serb Democratic Party (SDS) under the control of Radovan Karadzic" (Dziedzic and Blair 1998: 300). In 1997, SFOR 
began to directly confront the paramilitary police force in Repbulika Srpska which numbered around 2,000 to 3,000 officers at the time (NYTimes 1997a). Among these police forces were not just those under the command of the RS government, but also contingents which were controlled by wartime leaders. For example, in the August of 1997 NATO troops seized several police stations in Banja Luka that were controlled by police units loyal to Radovan Karadžić who had resigned from his post as President of Republika Srpska one year earlier but still competed with his successor, Biljana Plavšić (NYTimes 1997b). Eventually, cooperation between SFOR and the new RS government led to the demise of the MUPs (Dziedzic and Blair 1998: 299-300).

The disarmament of both militias and paramilitary police eliminated the two actors competing with regular police forces for the regulation of small-scale violence. Unlike in the cases where self-help communities existed, the local actors that controlled means of violence in the Bosnian civil war had no deeply rooted power base which would have supported their ongoing resistance against the statebuilding effort. The quick dissolution of the militias and local defense groups is exactly what we should expect based on the theory of small-scale violence regulation.

\section{Step Three: Consolidation}

The two entities have developed two very distinct approaches to policing. In Republika Srpska, the SDS has early on centralized control over police forces. RS has one Ministry of Interior that controls all of the police forces of the entity. Given its ethnic divisions, the FBiH has developed a much more decentralized system of policing. Each of the ten cantons of the Federation has its own MoI and police force (Ahić 2007: 371). It was this institutional context in which the UN would commence its policebuilding mission.

With the DPA of 1995, the UN established the International Police Task Force (IPTF). IPTF was provided with 1,721 officers who were supposed to be stationed across 109 Bosnian police stations. However, in its early phase the task force had a weak mandate that did not go much further than monitoring police forces, and deploying the complete force took several years (ICG 2002b: 6). In a stepwise process, the entities agreed to major cuts in their police forces while IPTF's mandate was broadened. In 1996, the Federation started cooperation with IPTF, and the Republika Srpska followed in 1998. In the same year, the mandate of IPTF was strengthened 
so that it was able to dismiss officers that were involved in human rights abuses during the civil war (Padurariu 2014: 4). This de-certification process was an important step in depoliticizing and professionalizing the police forces. In line with the overall personnel reduction targets, 18,000 police officers were screened, and 793 of them were eventually dismissed from services (Bliesemann de Guevara 2009: 191-192). From the first IPTF deployment in 1996 to the end of the mission in 2003, the entities reduced the numbers of their police forces from 44,000 to 16,000 . While that number was still seen as disproportionally large, it can be seen as a major achievement in de-militarizing policing in Bosnia (Perdan 2006: 193-194). Next to these reductions in the number of police forces, SFOR also collected 22,600 weapons from individuals, thereby strengthening the position of the police (Perdan 2006: 190).

From 2000 on, the statebuilders shifted their attention from the individual police officers to organizational issues. In order to strengthen the role of the central government, several specialized police organizations were created at the national level. In 2000, a State Border Police (SBS) was established in order to centralize the monitoring of the borders. In order to improve the co-ordination between entities and cantons, especially regarding the fight against organized crime, the State Investigation and Protection Agency (SIPA) was created in 2002. Both of these institutions were set up against the will of Repulika Srpska through the High Representative (Padurariu 2014: 4-5).

However, due to the still politicized nature of the police, attempts to reform broader organizational structures were often times blocked by the ethno-nationalist parties (Bliesemann de Guevara 2009: 196-197). In 2003, the UN passed policebuilding on to the EU. The Europeans deployed a greatly reduced force to policebuilding which also included 119 ex-IPTF personnel (Padurariu 2014: 6-7). EUPM had a less intrusive mandate, especially as it could not dismiss officers for human rights abuses. However, EUPM embarked on a highly ambitious effort to centralize the police system in Bosnia-Herzegovina. While this project was unnecessary with respect to the monopoly on violence, the intention was to strengthen the power of the central government. The restructuring of police districts along non-ethnic lines in particular proved to be extremely contentious and the RS put all its political weight against the reform effort (Muehlmann 2008: 4-6). After two and a half years of intense struggles between the Office of the High Representative and the RS, EUPM had to accept a face-saving proposal that barely 
concealed its political defeat (Muehlmann 2008: 9-11). The international policebuilding efforts ended in 2012 when EUPM officially closed down (Padurariu 2014: 7).

Overall, the statebuilding missions has created a smaller, more professional and more accountable police force, and it has established central state institutions that complemented community policing.

\section{Outcome: State Monopoly on Small-Scale Violence Regulation}

Bosnia-Herzegovina has a state monopoly on small-scale violence regulation. The highly federalized police structure does not outweigh the fact that there are no self-help communities. Bosnian small-scale violence is regulated by a unitary legal system. Legal pluralism does not exist in Bosnia-Herzegovina, as all laws are derived from the constitution and they are enforced by the police forces that have been trained by the international actors. Nevertheless, the fact that the constitution is an international peace treaty weakens its legitimacy, and there have been many calls for the creation of a real constitution. The Bosnian police forces are professional organizations that have been largely de-politicized and down-sized to a sustainable level. Furthermore, polls show that the system is widely accepted and trust in the institutions is on the rise, especially when compared to other Eastern European countries (EBRD 2010: 34). Given existing problems as the asymmetric federalism of police forces, it is easy to overlook the major success that SFOR and EUFOR have achieved. In 1995 when the intervention began, BosniaHerzegovina was controlled by dozens of militias and armed groups. Even a few years later, NATO still had to use large-scale force to seize cities such as Banja Luka from paramilitary control. However, by 2005 when the EU embarked on its centralizing reforms, such

What became clear in the case study is that the monopolization of small-scale violence was arguably not the major obstacles of the statebuilding intervention. Instead, the liberalization of state power and the establishment of a rule of law system were the real challenges. People did not doubt that the state is responsible for regulating violence, but they had different views over what such a state should look like (e.g. centralization v. ethno-federalism). It is important for future analyses of interventions to differentiate between these elements of (liberal) statehood in order to make more fine-grained judgments on success or failure of statebuilding. 


\subsection{Conclusion}

The case of Bosnia-Herzegovina offers several important insights regarding the monopolization of violence through international intervention. Since the UN and NATO got involved in the Bosnian conflict, there has been a lot of criticism for the highly intrusive style of intervention and the perception of disappointing outcomes. However, when the intervention began in 1995, Bosnia was devastated by civil war and fragmented into two entities that saw each other as enemies. Two decades later, the state has a monopoly on large-scale violence and small-scale violence regulation.

This chapter has argued that the monopoly on large-scale violence could be achieved because Croatia and Serbia cooperated with the statebuilders. The case of Bosnia-Herzegovina is especially useful because it shows a within-case transition from a competitive into a cooperative regional environment. When Bosnia's two neighbors transitioned to democracy and recalibrated their foreign policy towards EU integration, nationalist hardliners within BiH lost power vis-à-vis those who favored integration. Hence, whereas a unification of the wartime enemies seemed utopian during the 1990s, the creation of a monopoly on large-scale violence eventually succeeded in 2005 .

The intervention also succeeded in monopolizing the regulation of small-scale violence in the hands of the state. Given the large number of small-scale violence actors during the civil war, this outcome could be seen as surprising. This chapter argued that it was the long-term state formation in Bosnia-Herzegovina that enabled the statebuilders to succeed. Generations of Bosnians had been socialized in an environment in which the state was the only source of law as well as the only agent who controls the means to enforce it. The deeply entrenched acceptance of a state-centered order of violence and a lack of self-help communities enabled the international intervention to succeed in re-establishing a state monopoly on small-scale violence.

The example of Bosnia and the Balkans strengthens the assumptions underlying this dissertation. In statebuilding interventions, the monopoly on large-scale violence can be created quickly if the regional context is favorable. In contrast, orders of violence are deeply ingrained into societies and will determine whether an interventions leads to a state-centered order of violence or a fragmented order of violence. However, the case also shows that a monopoly on 
violence cannot be equated with 'good governance' or even stable statehood. BosniaHerzegovina's political divisions remain strong and the risk of a renewed breakup of the state has not vanished. 


\section{Conclusion: What Future for Statebuilding and State Formation?}

I started out by arguing that liberal statebuilding interventions always involve efforts to monopolize the means of violence because the widely accepted definition of an ideal typical state demands that the state has to have a monopoly on violence. The purpose of this dissertation was to explain why statebuilding interventions succeed or fail to establish a state monopoly on violence. In a first step, I examined the literature on state formation and re-conceptualized the 'monopoly on violence'. There are two types of violence that are typically regulated by institutions: Large-scale violence (i.e. organized violence or warfare) and small-scale violence (i.e. inter-personal violence). The distinction is important for statebuilding because different forms of violence require different institutions for their regulation. Only a state that has exclusive control over both types of violence regulation can be considered to have a monopoly on violence.

Given these considerations, studying the conditions under which liberal statebuilding interventions succeed or fail to create a monopoly on violence needed to be split up into two separate questions:

1. Under which conditions do statebuilding interventions fail or succeed to create a state monopoly on large-scale violence?

2. Under which conditions do statebuilding interventions fail or succeed to create a state monopoly on small-scale violence regulation?

First, I argued that statebuilding interventions are likely to succeed in creating a monopoly on large-scale violence when key regional actors support the intervention. Statebuilding interventions combine large military deployments with massive inflows of funding. Any armed actor that wants to resist such externally-led monopolization processes needs to be wellorganized, protect its leadership and re-supply its fighters. Without an effective transnationalization strategy, armed groups are unlikely to successfully resist disarmament because they cannot sustain the necessary organizational capacities. Whether they can make use of transnational spaces depends on the policy of regional powers and direct neighbor countries. When these key regional actors deny armed groups cross-border sanctuaries, statebuilding will succeed in building and consolidating a monopoly on large-scale violence. However, where key regional actors undermine the monopolization effort, statebuilding will eventually fail to disarm 
armed groups and build reliable armed forces. Under these circumstances, armed groups will be able to sustain the organizational means of warfare. This survival strategy allows armed groups to withstand monopolization efforts and drive up the costs of statebuilding for the external actor. The combination of these high costs and the short-termism of external intervention will cause interventions to end before a monopoly on large-scale violence could be established.

Second, I have argued that statebuilding interventions' effect on small-scale violence regulation depends on the longue durée of state formation in a given society. Statebuilding interventions introduce liberal institutional frameworks (e.g. by drafting a new constitution or reforming existing institutions), and they support governments in building modern police forces. They are likely to succeed in creating a state monopoly on small-scale violence regulation in countries with a history of strong statehood. In these societies, the state has assumed responsibility for rule making and rule enforcement a long time ago. The population has been socialized into a state-centric order for decades or centuries. Where these conditions apply, the expectations that the state should regulate small-scale violence are robust even throughout civil wars. Despite tendencies of militarized policing and the emergence of militias, no local constellation achieves the level of institutionalization that characterizes self-help communities (i.e. strong non-state institutions of small-scale violence regulation). Therefore, the externally-led effort to dissolve militias, de-militarize police forces and introduce liberal elements of democratic policing is accepted by the population and cannot be effectively countered by local non-state elites. In societies where there has never been a strong state, statebuilding interventions will fail to build a state monopoly on small-scale violence regulation. In these states, self-help communities provide the population with rules and rule enforcement at the local level. Before crisis and intervention, these societies often had police presence in the cities while the rural areas were controlled by self-help communities; they were para states. Through civil war or regime change, state policing tends to collapse while the strong local institutions such as chiefdoms, village councils or tribal communities remain in place. At the beginning of statebuilding intervention local elites are in a powerful position as the government depends on them, and they are likely to capture the statebuilding project early on. The replacement of self-help communities is a protracted long-term process of coercion, bargaining, and socialization. Thus, intervening actors will liberalize institutions and build police forces, but they will refrain from engaging in a true monopolization process. As a result, the outcome of intervention is a return to para 
statehood: The state has no monopoly on small-scale violence regulation as state and non-state institutions of small-scale violence regulation co-exist. Overall, the two conditions were analyzed separately in order to increase analytical leverage. However, statebuilding interventions could only lead to a full monopoly on violence where both conditions were present.

In order to develop these causal mechanisms and test them, I conducted three case studies. By providing three detailed process-tracing analyses I sought to present evidence for my theoretical argument and discuss alternative explanations. Each case study first contextualized the intervention by providing a brief history of state formation, and then provided distinctive analyses for each of the two types of violence regulation. Overall, the cases provided strong evidence for my proposed explanation. The two young states with a history of colonization, Sierra Leone and Afghanistan, both had weak central governments throughout their histories. Despite the external actors' great investments into liberal institutions and capable police forces, the existing social structures prevented a successful monopolization of small-scale violence. Selfhelp communities proved too deeply rooted in society, and local elites who gained their power from these institutions continue to dominate the politics of the state. Although the two states have similar social structures, large-scale violence regulation has succeeded only in one of them. Whereas the second biggest liberal statebuilding intervention in history (in terms of troops deployed) has not prevented Afghanistan from entering its fourth decade of civil war, the intervention in Sierra Leone can be considered one of the most successful statebuilding missions. While neither the small differences in intervention-related factors nor domestic structures offered convincing explanations for the variation, there was strong evidence that the regional political constellation greatly influenced the ability of the statebuilders to monopolize the means of warfare. In Afghanistan, the major armed groups all operated across the border with Pakistan. Therefore, they could sustain a rebellion against NATO for over a decade. In contrast, the RUF in Sierra Leone collapsed quickly once a regional coalition and UN forces deprived it of its Liberian cross-border sanctuary.

Compared to Afghanistan and Sierra Leone, Bosnia-Herzegovina appeared to be an outlier. Despite never being a sovereign state until the 1990s, it had a history of strong statehood. The foundations for the successful monopolization of small-scale violence regulation reach back to the tanzimat reforms of the Ottoman Empire in the $19^{\text {th }}$ century. Thus, efforts of the statebuilders to monopolize small-scale violence regulation in the hands of the state were 
successful as they amounted to a reconstruction of institutions that have been unrivalled in Bosnian society. However, as I have argued, when it comes to large-scale violence, Sierra Leone and Bosnia shared a favorable regional setting. Unlike in other regions of the world, the interveners (NATO and EU) were so powerful in the Balkans that they could help transform the regional political context to a certain extent. Thereby, key regional actors changed their stance towards $\mathrm{BiH}$ during the statebuilding intervention. While the monopolization of violence in Bosnia-Herzegovina was overall successful, the case has also shown that a stable state cannot rely solely on its control over means of coercion. Political divisions along ethnic and entity lines remain potential causes of instability. Nevertheless, political integration will be easier under the security umbrella that the state monopoly on violence provides.

\section{Does the theory work for other cases of liberal statebuilding intervention?}

In the beginning I decided to limit my universe of cases in order to control for several potential explanatory factors. Limiting the population should increase the likelihood that the findings of a small-n comparison are generalizable to other cases of the phenomenon. There is of course no room here for further case studies, but it might be useful to check the plausibility of my explanation for other cases. Hence, I will briefly discuss three major statebuilding endeavors in light of my findings: Liberia, Iraq, and Kosovo.

\section{Liberia}

As the case study on Sierra Leone has shown, the Sierra Leonean and the Liberian civil wars were deeply interwoven. Intervention in Liberia began in 2003, at a time when Sierra Leone was already pacified. The statebuilding intervention in Liberia has not yet resulted in a consolidated monopoly on large-scale violence although all armed groups have been disarmed. Hence, whether the state will eventually have exclusive control over the means of warfare is yet to be seen. In contrast, Liberia is a para state and there a few signs that the intervention could result in a state monopoly on small-scale violence regulation. 
In terms of large-scale violence regulation, the outcome of the intervention can best be described as a qualified success. There has been no more fighting in Liberia since the beginning of the intervention. The UN Mission in Liberia (UNMIL) succeeded in quickly disarming the three armed groups; by the end of 2004, over 100,000 combatants had been disarmed (Munive and Jakobsen 2012: 365). The creation of new Armed Forces of Liberia (AFL) was undertaken by the US and began in 2005 with the dismantling of all old defense structures (Nilsson and Kovacs 2013: 6-8). Since 2006, US trainers have rebuilt a small professional army of about 2,000 soldiers. Although the size of the force might raise concerns about its effectiveness, it makes the army much more affordable for a poor country like Liberia (Nilsson and Kovacs 2013: 11). Despite progress in the realms of DDR and SSR, UNMIL still has a substantial troop deployment in Liberia (about 7,000). Thus, it is too early for a conclusive assessment of the outcome. However, it is possible to investigate whether we find evidence for the regional cooperation mechanism in Liberia. Liberia and Sierra Leone are neighbor states and hence are part of the same region. Therefore, many insights from the Sierra Leone case study also apply to Liberia. Major regional actors such as Nigeria and Liberia's neighbors have supported the intervention. ECOWAS militarily intervened in Liberia, mainly with Nigerian troops. Neighboring Côte d'Ivoire and Guinea supported anti-Taylor forces, thereby forcing the government indirectly to agree to the peacekeeping mission (ICG 2003). Taylor's National Patriot Front of Liberia received strong support from Cote d'Ivoire in the early stages of the First Liberian Civil War. In 2003, the new Ivorian government had turned against Taylor and started supporting the armed group Movement for Democracy in Liberia (MODEL) (Hazen 2013: 131-133). By summer 2003, the rebel groups had surrounded the capital. Pressure by regional and international actors led to the signing of the Comprehensive Peace Agreement which included the deployment of a peacekeeping force (Gerdes 2013a: 165-168). Overall, there is some evidence that the regional cooperation mechanism is at work in Liberia, and that the country might be on a path towards a consolidated monopoly on large-scale violence.

At the level of small-scale violence, Liberia also shares many features with Sierra Leone. Although Liberia has never been a colony, it also never had a strong state. Liberia's self-help communities in many respects resemble Sierra Leone's chieftaincies, but they are more informal (and perhaps therefore, they are also less well researched). There are chiefs and elders at different levels of hierarchy, ranging from quarter chiefs to paramount chiefs (Isser et al. 2009: 23). 
Furthermore, different forms of watch groups or vigilante groups have formed (Kantor and Persson 2010: 21-22). Again, as predicted by the weak state legacy mechanism, self-help communities have existed prior to and after the civil war. As Isser et al. (Isser et al. 2009: 25) have pointed out, "[..] customary institutions and practices of justice have clearly survived Liberia's devastating civil war and remain active in virtually all of Liberia's rural communities". In addition to these institutions, many communities were also controlled by local commanders during the war. When the state of Liberia was rebuilt after 2003, many local elites managed to tap into the new institutions and re-establish patrimonial networks between rural hinterlands and Monrovia (Reno 2008: 395-397). When the statebuilding intervention began in 2003, the state police force was in shambles. Since then, UNMIL has sought to rebuild the Liberia National Police (LNP). Compared to its neighbor country, the police-building process in Liberia has proven more difficult. Within its first ten years, the LNP failed to reach the personnel strength that was deemed necessary for the population size of Liberia and over thousand international police trainers are still deployed (Caparini 2014: 11-15). Therefore, the police-building efforts in Liberia were less effective than those in neighboring Sierra Leone (Kantor and Persson 2010: 1617). Overall, Liberia's small-scale violence regulation is conducted both by a deficient police force and by self-help communities. Therefore, even if the monopolization of large-scale violence will eventually succeed, the intervention has not led to a full monopoly on violence.

\section{Iraq}

A major case of international statebuilding was the US mission Iraq Freedom. The Iraq War was no post-conflict peacebuilding mission, but a regime change intervention. Unlike many other cases where mission creep turned light foot print peacekeeping into complex statebuilding interventions, the war in Iraq was followed instantly by wide-ranging reforms that resembled the American occupation of Germany after World War II. Iraq was put under control of a Coalition Provisional Authority (CPA) which governed the country and took drastic measures to build new security forces from scratch (Ricks 2007). Nevertheless, the statebuilding effort failed to monopolize both large-scale violence and small-scale violence regulation. There is some evidence that the same mechanisms were at work as in the three case studies of this dissertation. 
Large-scale violence monopolization has largely failed. At the regional level, the US intervention in Iraq was opposed by all of Iraq's neighboring countries except Kuwait. Regional powers had greatly diverging interests with regard to Iraq. Iran opposed Saddam Hussein's regime as well as the US, and it responded to the invasion by supporting Shia parties and militias. Complementarily, Saudi-Arabia feared a strengthening of Shia Islam and Iran's power in the region (Nasr and Takeyh 2008). Both Syria and Turkey opposed the American war. As a resul t, the three ethnic groups of Iraq were supported by different regional actors and were all able to sustain means of large-scale violence to varying degrees. The Sunni insurgency that was focused mainly on the Anbar province consisted of several elements. In its early phase, Baathists were crucial for setting up the rebellion. However, foreign fighters under the label of Al-Qaida in Iraq took control and became the major armed group of the region (Baram 2005). While there is no conclusive data on the Anbar insurgents, the rate of foreigners in the ranks of al-Qaida was extremely high. Many of the insurgents fighting in the Iraq war were 'foreign fighters' from the region (Guardian 2007b). Syria used its control over the border region as a policy tool by increasing and reducing the flow of resupplies (WashingtonPost 2005). At the height of the conflict, US officials estimated that up to $90 \%$ of foreign fighters entered Iraq via Syria (Guardian 2007a). Meanwhile, the Kurdish autonomous region could defend its quasi-statehood due to its military strength. Unlike in the case of al-Qaida in Iraq or the Shia militias, the statebuilders did refrain from disarming and integrating the Kurds. On the one hand, Kurdistan was very stable in comparison to other parts of the country. On the other hand, the costs of disarming the Kurds would have been immense for the US and the Iraqi government. After informal contacts with the Turkish intelligence apparatus were developed in 2005, Kurdistan has developed increasingly formal relations with Turkey which allowed it to sell oil and become fiscally more independent of Bagdad (Cagaptay and Evans 2012: 15-18). At the time of writing, the war between the armed group Islamic State and a wide range of regional actors underlines the importance of regionally accepted territoriality for the creation of stable monopolies on largescale violence.

At the level of small-scale violence regulation, many have mistaken Iraq under Saddam Hussein for a modern state that could directly rule over its population. In fact, this was not the case as the regime greatly depended on its alliance with various tribes. Although there were attempts at monopolizing small-scale violence regulation at the height of Saddam Hussein's 
power, he had to resort to cooperation with the tribes after lost wars against Iran and the US weakened Iraq's state (Baram 1997: 10-12). The Iraqi National Police remained a militarized and corrupt force with weak ties to local communities (Deflem and Sutphin 2006: 269). However, it took the US interveners several years to recognize the strength of self-help communities. Despite a massive expansion of the Iraqi police force, Sunni tribes remain important self-help communities. Arguably, the tribes have even become stronger since the National Police was used as a tool of ethnic cleansing by the Shia-dominated Ministry of Defense during the civil war of 2006-2007 (Dodge 2012). The case of Iraq also highlights the interaction between self-help communities, armed groups and the state. Whereas the security forces were seen as Shia tools for ethnic cleansing, al-Qaida appeared to be the more bearable option. However, when the US assured the tribes that they would enjoy protection and a greater role in the new state, the tribal leaders joined the US offensive against al-Qaida. When it became clear that after the US withdrawal, the Iraqi government would once again exclude the Sunnis from policy-making, the tribes embraced an armed group that opposed the state (NYTimes 2014c). The example of Fallujah is instructive when it comes to small-scale violence regulation: Since the US invasion of Iraq, the city has been conquered by several armed actors including US forces, the Iraqi government, al-Qaida and the Islamic State. During this period, tribal sheiks have remained the dominant local elites and have constantly tried to secure the safety of their self-help communities by balancing and bandwagoning the large-scale violence actors (Green 2010: 594-598; WashingtonPost 2014) (Christia 2012: 236). The bottom line is that the exclusion of local elites from the statebuilding process makes it easier for armed groups with access to external assistance to expand their territorial control.

\section{Kosovo}

As in the case of Liberia, intervention in Kosovo is still ongoing. Similar to Bosnia-Herzegovina until 2005, the overall outcome of statebuilding in Kosovo can be described as a fragmented state: While small-scale violence regulation is completely bureaucratized, the central government has no monopoly on large-scale violence. In terms of large-scale violence, the intervention of NATO and the UN has so far failed because North Kosovo, which has a Serb majority, still resists the integration into a unified state. Although Kosovo is located in the same region as 
Bosnia-Herzegovina, the Serb government does not cooperate with the statebuilders because it views Kosovo as Serb territory (BTI 2014c: 5-6). Thus, political parties and nationalist hardliners have received strong political and monetary support by Serbia (ICG 2011: 3-5). Outside these territories, monopolization has succeeded by disarming the irregular Kosovo Liberation Army (KLA) and by creating of a 2,500-strong armed Kosovo Security Force (Baliqi 2012: 26-27). As in the case of Bosnia-Herzegovina, there is a chance that the EU eventually transforms the regional constellation. The long-term question for Kosovo's monopolization of large-scale violence regulation will be whether Serbia values EU membership higher than its claims to Kosovo.

However, in most parts of the country a state monopoly on small-scale violence has been achieved. Kosovo has experienced a state formation process that can be compared to BosniaHerzegovina's. It has been subject to the same set of tanzimat reforms as other Ottoman provinces, and since 1912 it has been subject to monopolization processes in Serbia and later Yugoslavia (Glenny 2012: 366-368). However, this process had been partly reversed after the Milosevic government began excluding non-Serbs from state institutions. Wilson (2006: 157) argues that in response, "[..], ethnic Albanians returned to using traditional alternative dispute resolution mechanisms and reconciliation councils, essentially a form of arbitration overseen by village elders". Nevertheless, these provisional justice mechanisms have arguably not achieved the degree of institutionalized small-scale violence regulation that can be observed in cases such as Afghanistan or East Timor. After the war the UN was involved in drafting a liberal constitution (ICG 2011: 2), and UNMIK International Civilian Police (CIVPOL) began to rebuild the police as a democratically accountable force of 4,000 police officers (Baliqi 2012: 27-28). Overall, the police and justice system have been rebuilt as a liberal order that provides public security (Wilson 2006: 167-172). The case of Kosovo thus by and large corroborates my theory, although more research would be needed on the role of traditional justice in Kosovo prior to the intervention.

In sum, the brief discussion of statebuilding intervention cases indicates that the explanation works fairly well for the general population (see table 1). However, the cases also show that the connection between armed groups and self-help communities might be of greater importance in 
some cases than in those I have studied. Furthermore, the case of Kosovo prompts questions about the speed with which self-help communities can (re-)emerge during times when the state is absent as a regulator of small-scale violence. I will now conclude the dissertation by discussing the wider implications of my findings for scholars and policy-makers.

\section{Contributions and Future Research}

What implications do my findings have for peacebuilding research and related fields of study? In recent years, peacebuilding research has experience a so-called 'local turn' (Mac Ginty and Richmond 2013). Scholars have increasingly focused on the local level of conflict-ridden societies in order to explain the outcomes if interventions (Autessere 2010; Boege et al. 2008; Mac Ginty 2010a; Manning 2003; Richmond 2010; Schetter et al. 2006; Wallis 2012). These efforts were highly important as they have uncovered the hitherto hidden local social structures that had been neglected by the first wave of statebuilding research. My analysis of small-scale violence owes much to the theoretical and empirical insights that has been generated by this strand of research. However, there has been a tendency to increasingly depict 'the local' as a micro cosmos that is rather detached from national politics. As Mac Ginty and Richmond (2013: 769) argue, "[a] local peace may be influenced by a formal peace accord, or national political dynamics, but it is designed locally and may buck national or international trends". They criticize 'liberal' approaches that emphasize the embeddednes of the local in wider state structures (Mac Ginty and Richmond 2013: 779-780). In contrast, my dissertation corroborates the arguments of scholars who see local actors as strongly interdependent with both the central government and intervening actors (Autessere 2010; Barnett and Zuercher 2009; De Waal 2009). My contribution to the latter school of thought is a more institutionalist perspective: So far, the existence of local elites (in the form of 'strongmen', 'elders', 'warlords', etc.) has often been taken for granted. A stronger focus on local institutions could illuminate local elites' sources of power and authority, which in turn would improve our understanding of the relation between local elites and central governments. Therefore, an institutionalist approach to small-scale violence regulation will improve our understanding of current patterns of statebuilding and state formation in developing countries. 
Whereas the local has received a lot of attention in recent years, the regional level has oddly been ignored. Despite growing interest in state formation, the centrality of the region for the emergence of modern states has been neglected by statebuilding scholars. To my knowledge, Haldén $(2010,2013)$ has so far been the only one who has taken the effects of regional social systems on statebuilding seriously. This is even more surprising given the fact that other fields have been debating the role of regional politics for over a decade. Since the introduction of the concept of regional security complexes in International Relations (Buzan and Wæver 2003), recent advances in the study of civil war (Gleditsch 2007; Pugh et al. 2003; Salehyan 2007) and democratization (Zuercher et al. 2013) have revealed the strong clustering of certain political phenomena in regions. My dissertation has shown that these insights are of great relevance for peacebuilding and statebuilding. However, my findings also have an implication for the study of civil war. The 'bad neighborhood' argument on which I partly based my argument is a useful but incomplete approach (Gleditsch 2007; Hazen 2013). While the findings from Afghanistan and the early phase of intervention in Bosnia-Herzegovina support the argument that armed groups benefit from cross-border support, the theory needs to be amended by including a 'good neighborhood' aspect: Statebuilding can be greatly accelerated by regional cooperation. Therefore, future research on interventions as well as on civil war has to place a much greater emphasis on the regional actors and institutions that could potentially affect the internal dynamics of statebuilding. Any study that focuses only on the national level runs the risk of omitting crucial variables.

This dissertation aimed at providing a theoretical framework that allows researchers to analyze the relation of statebuilding interventions and violence regulation. It developed a theory and then put it to the test in three case studies. This approach has of course clear limitations. For one, the study could have benefited from data collected specifically for the analysis of violence regulation. However, systematic field work in three (former) conflict zones was beyond the scope of this doctoral project. Furthermore, the generalizability of my findings is limited by the small sample of cases. Finally, I have focused only on a very tightly defined population of cases. From these limitations follow two imperatives for future research. One option for further research is to build and test more generalizable theories based on my analytical framework. For example, expanding the population would make the theory more amenable to large-N studies. However, this would also require amending central concepts by strengthening their operationalization. Do 
the general assumptions hold across all cases of peacekeeping interventions? Are there regions or types of states that work entirely differently than we would expect based on the theory proposed in this book?

Second, detailed field work could improve or alter the causal mechanisms that have been explicated in this study. With regard to large-scale violence, there is still much to be learned about the organization of armed groups as well as about the politics that occur at a regional level. In settings where political elites do not produce as much formalized paperwork as EU leaders in Brussels do, tracing decision-making is much harder without access to the actors involved. Better data on these processes is hard to come by but would immensely improve our understanding of state formation and state collapse. With regard to small-scale violence, there has been very little research on what I have called self-help communities. There are many potential research questions that would require a combination of in-depth field work and comparative methods. What types of self-help communities exist? How do they regulate violence in practice, and what other functions do these institutions fulfill for their constituencies? What are the major sources of authority for local elites in different forms of self-help institutions? Apart from these micro-level issues, another important aspect is the connection between self-help institutions and large-scale violence dynamics. First steps in this area have been taken by scholars of militias in civil wars. As my discussion of these actors has shown, militias often operate at the intersection of micro and macro level violence. Some of them are just well armed self-help communities who defend their local area against a large-scale violence actor. Other militias are alliances of self-help communities and become themselves major actors in civil wars. Militia politics are only one example of the interactions between actors and institutions of micro-level and macro-level violence. Research in these areas is costly and often dangerous, but the field of study has great potential to improve and to alter our understanding of violence, war, and social order.

\section{Policy Implications and Outlook}

For policymakers and weak state societies, my dissertation provides three major practical conclusions with regard to limitations of interventions, conditions for successful statebuilding, and the flexibility of statebuilding. 
First, there are clear limitations to what statebuilding interventions can achieve. I have argued that interveners cannot successfully monopolize the means of violence against the interests of states in the region (large-scale violence) or those of powerful local elites (small-scale violence). Whereas problem-solving scholars have suggested that statebuilding can succeed if only it applies the rights strategies, there appear to be limitations that are beyond external actors' control. This finding implies that policymakers should avoid interventions in regions where powerful neighboring states are hostile to an external statebuilding mission. Furthermore, the importance of regional politics for the monopoly on large-scale violence suggests that intervention policies need to include regional states to a much greater extent. As the example of former Yugoslavia shows, powerful international actors might be able to facilitate cooperation in certain contexts. However, on a global scale there is reason for pessimism as the relative power of Western actors is in decline. Regional powers are increasingly able to position themselves against US or European interests, and the rise of a multipolar international system provides them with potential great power allies such as China or Russia. In contrast to regional states, any compromise with local elites will undermine the establishment of a monopoly on small-scale violence. The best outcome statebuilders could achieve under these circumstances is a wellregulated para state in which the relation between central government and local elites is clearly specified. However, prospects for statebuilding interventions are not as gloomy as this first insight suggests.

The second policy implication gives reason for optimism that statebuilding intervention can build monopolies on violence and thereby spare societies the fate of instability and civil war. In contrast to the general pessimism of both critical scholars and recent political sociology studies, statebuilding has proven to work well when specific conditions are met. Interveners have succeeded in creating stable states that control both the means large-scale violence and smallscale violence regulation. Better analyses of the regional, local and historical context prior to intervention could reduce the number of military missions that fail to monopolize violence. Given how many people were killed in interventions in Afghanistan or Iraq, a reduction of the number of misguided statebuilding interventions could save a great number of lives. However, military interventions are often the result of political compromises in reaction to emergency situations. Therefore, the room for proper investigations into the social context of potential target countries is most likely very limited. 
Third, the case studies suggest that a more flexible approach to statebuilding could be in the interest of both interveners and the affected societies. Some might interpret my findings as yet another nail in the coffin of liberal peacebuilding. Most countries that are prone to civil war and interventions are also likely to be dominated by strong self-help communities. It seems unrealistic to build a consolidated democracy or introduce the rule of law in a country governed by legal pluralism and neopatrimonial networks. However, the creation of a stable para state could be in the interest of both intervening and domestic actors. While one can certainly criticize the Sierra Leonean state in many respects, its combination of an electoral democracy with strong local chiefs has provided the population with stability and economic growth during the last decade. More generally speaking, the bottom line is that intervening actors have to re-learn the art of politics. Building a state is often a series of compromises, and in the realm of violence regulation these compromises can be necessary at all levels from the region to the village. Compromising on basic liberal values is a form of realpolitik that is seen as appalling by Western publics, but in some cases it might be the only way for external actors to help war-torn societies. Overall, the policy implications of my findings can be summarized in the formula: Intervene only where conditions are favorable, and adapt to local context.

All of these insights would be redundant if the age of statebuilding interventions already over (Richmond 2014). So far, research on statebuilding has been the study of an ongoing political process. It is unclear whether liberal statebuilding interventions will stay with us or whether they were the expression of very specific historical circumstances. Western publics have grown tired of protracted interventions that lead to casualties and gruesome pictures of civil war violence. Nevertheless, there are signs that interventionism and statebuilding are here to stay. The most recent Western interventions in Lybia, the Sahel Zone and Iraq have been characterized less by statebuilding and more by military action against Islamists or unsolicited governments. However, this does not mean that liberal interventionism is dead, as UN-led missions in the Central African Republic, Mali, or South Sudan display the typical characteristics of liberal statebuilding interventions. Ironically, liberal statebuilding might have simply shifted away from liberal states to the UN and regional organizations such as the African Union.

While it is possible that the age of statebuilding interventions is over, the possibility of a new era of isolationism seems implausible. World society has become so highly inter-connected that the self-sufficient nation state is at the very least a historic phenomenon (if it has ever 
existed). During the writing of this dissertation, whole regional state systems have collapsed in the Middle East and Northern Africa while the war in Ukraine has brought conflict and state fragmentation back to Europe. The more interdependent the world becomes, the more states will see their interests endangered by instability and conflict in distant places. State formation in the $21^{\text {st }}$ century is likely to be a highly globalized process. Therefore, it would not be surprising if statebuilding interventions, in one form or another, stay with us for the coming decades. 


\section{Bibliography}

Abrutyn, Seth and Kirk Lawrence. (2010): "From Chiefdom to State: Toward an Integrative Theory of the Evolution of Polity." Sociological Perspectives 53(3):419-442.

Acemoğlu, Daron, Tristan Reed and James A. Robinson (2013): "Chiefs: Elite Control of Civil Society and Economic Development in Sierra Leone." NBER Working Paper Series Working Paper 18691.

Acemoğlu, Daron and James A. Robinson (2012): Why nations fail: the origins of power, prosperity, and poverty. 1. ed. Edition. New York, NY: Crown Publ.

Afghanistan Compact, The (2006): "The London Conference on Afghanistan. 31 January - 1 February 2006." London, UK: The Islamic Republic of Afghanistan and the international community.

AFP (2007): "Liberia, SLeone re-open border after 17 years."

2014(04.12.).http://reliefweb.int/report/liberia/liberia-sleone-re-open-border-after-17-years accessed on 04.12. 2014

Afrobarometer (2013): "Afrobarometer Round 5." 2013(21.10.).http://www.afrobarometer.org/ accessed on 21.10. 2013

Ahić, Jasmin (2007): "The Reconstruction of the BH Police Force " In Security Sector Governance in the Western Balkans: Self-Assessment Studies on Defence, Intelligence, Police and Border Management Reform eds. Anja H. Ebnöther, Philipp H. Fluri and Predrag Jurekovic. Vienna and Geneva: Geneva Centre for the Democratic Control of Armed Forces (DCAF).

Ahram, Ariel (2011): Proxy Warriors. The Rise and Fall of State-Sponsored Militias. Stanford, California: Stanford University Press.

Albrecht, Peter Alexander (2010): "Transforming Internal Security in Sierra Leone: Sierra Leone Police and Broader Public Sector Reform." DIIS Report 2010:07.

Albrecht, Peter and Paul Jackson (2009): "Security System Transformation in Sierra Leone, 19972007." Birmingham, UK.

Allcock, John (2000): Explaining Yugoslavia. New York: Columbia University Press.

Alli, W.O. (2012): The Role of Nigeria in Regional Security Policy. Abuja, Nigeria: Friedrich-EbertStiftung.

Andersen, Peter C. (2001): "Interview with Police Inspector-General Keith Biddle." 2013(15.10.).

Freetown, Sierra Leone: Sierra Leone Web.http://www.sierra-leone.org/Archives/newsmaker-061701.html accessed on 15.10.2013

Andreas, Peter. (2004): "The Clandestine Political Economy of War and Peace in Bosnia." International Studies Quarterly 48(1):29-51.

AsiaFoundation (2013): "Afghanistan in 2013. A Survey of the Afghan People." Kabul, Afghanistan: The Asia Foundation.

Autessere, Séverine (2010): The Trouble with the Congo. Local Violence and the Failure of International Peacebuilding. Cambridge, UK: Cambridge University Press.

Azinović, Vlado, Kurt Bassuener and Bodo Weber (2011): "Assessing the potential for renewed ethnic violence in Bosnia and Herzegovina: A security risk analysis" Atlantic Initiative. Sarajevo and Berlin: Democratization Policy Council.

Bah, Alhaji Sarjoh (2012): "Sierra Leone." In Exit Strategies and International State Building, ed. Richard Caplan. Oxford, UK: Oxford University Press. 
Bailey, John and Matthew M. Taylor (2009): Evade, Corrupt, or Confront? Organized Crime and the State in Brazil and Mexico.

Baker, Bruce (2008): Multi-choice policing in Africa. Uppsala: Nordiska Afrikainstitutet.

Baker, Bruce (2010): "Sierra Leone Police Reform: the role of the UK government. Discussion Paper: 10-06." Tokyo, Japan: GRIPS Policy Research Center.

Baliqi, Bekim (2012): "Security Sector Reform in Kosovo: From Institutional Transitions to the Democratic Consolidation ": Available at SSRN: http://ssrn.com/abstract=2421264. Available at SSRN: http://ssrn.com/abstract $=2421264$ accessed on

Baram, Amatzia. (1997): "Neo-Tribalism in Iraq: Saddam Hussein's Tribal Policies 1991-96." International Journal of Middle East Studies 29(1):1-31.

Baram, Amatzia (2005): "Who Are the Insurgents? Sunni Arab Rebels in Iraq." Special Report. Washington D.C.: United States Institute of Peace.

Barnett, Michael and Christoph Zuercher (2009): "The peacebuilder's contract: How external statebuilding reinforces weak statehood." In The dilemmas of statebuilding.Confronting the contradictions of postwar peace operations, eds. Roland Paris and Timothy D. Sisk. London: Routledge.

Barzegar, Kayhan. (2009): "Iran's Foreign Policy Strategy after Saddam." The Washington Quarterly 33(1):173-189.

BBC (2007): "Bosnia war dead figure announced."

2014(02.07.).http://news.bbc.co.uk/2/hi/europe/6228152.stm accessed on 02.07. 2014

Beach, Derek and Rasmus Brun Pedersen (2013): Process-tracing methods : foundations and guidelines. Ann Arbor: University of Michigan Press.

Bellows, John and Edward Miguel. (2009): "War and local collective action in Sierra Leone." Journal of Public Economics 93(11-12):1144-1157.

Berdal, Mats R, Gemma Collantes-Celador and Merima Zupcevic Buzadzic (2012): "Post-war violence in Bosnia and Herzegovina." In The peace in between : post-war violence and peacebuilding, eds. Mats R. Berdal and Astri Suhrke. London ; New York: Routledge.

Berdal, Mats R. and Astri Suhrke (2012): The peace in between : post-war violence and peacebuilding. London ; New York: Routledge.

Berdal, Mats R. and Dominik Zaum (2012): Political economy of statebuilding : power after peace. New York: Routledge.

Berg, Louis-Alexandre. (2012): "Guns, Laws and Politics: The Political Foundations of Rule of Law and Security Sector Reform." Hague Journal on the Rule of Law 4(Special Issue 01):4-30.

Berg, Louis-Alexandre. (2014): "From Weakness to Strength: The Political Roots of Security Sector Reform in Bosnia and Herzegovina." International Peacekeeping 21(2):149-164.

Bliesemann de Guevara, Berit (2009): "Staatlichkeit in Zeiten des Statebuilding : Intervention und Herrschaft in Bosnien und Herzegowina." Frankfurt am Main ;: New York : P. Lang,.

Bliesemann de Guevara, Berit (2012): Statebuilding and state-formation : the political sociology of intervention. Milton Park, Abingdon, Oxon ; New York: Routledge.

BMZ (2012): "Für eine kohärente Politik der Bundesregierung gegenüber fragilen Staaten Ressortübergreifende Leitlinien -." Berlin, Germany: Bundesministerium für wirtschaftliche Zusammenarbeit und Entwicklung. 
Boege, Volker, M. Anne Brown, Kevin P. Clements and Anna Nolan (2008): "On hybrid political orders and emerging states: What is failing - states in the global south or research and politics in the West?" Berghof Handbook for Conflict Transformation Dialogue Series 8:15-35.

Boehnke, Jan, Jan Koehler and Christoph Zuercher (forthcoming): North East Afghanistan Longitudinal Study (NEALTS), 2007 - 2013.

Boyle, Michael J. (2014): Violence after War: Explaining Instability in Post-Conflict States. Baltimore, ML: John Hopkins University Press.

Bratton, Michael. (2007): "Formal versus Informal Institutions in Africa." Journal of Democracy 18(3):96-110.

Braudel, Fernand. (1958): "Histoire et Sciences sociales: La longue durée." Annales. Histoire, Sciences Sociales 13(4):725-753.

Bremer, Stuart A. (1992): "Dangerous Dyads: Conditions Affecting the Likelihood of Interstate War, 1816-1965." Journal of Conflict Resolution 36(2):309-341.

Brljavac, Bedrudin. (2012): "Building a Common State Army Forces in Post-War Bosnia and Herzegovina: Assessing its Peace-Building Perspective." Romanian Journal of European Affairs 12(1):2738.

BTI (2012): Bertelsmann Transformation Index 2012 - Dataset.

BTI (2014a): Bertelsmann Transformation Index 2014 - Dataset.

BTI (2014b): "Country Report - Guinea." Gütersloh, Germany: Bertelsmann-Stiftung.

BTI (2014c): "Country Report - Kosovo." Gütersloh, Germany: Bertelsmann-Stiftung.

BTI (2014d): "Country Report - Nigeria." Gütersloh, Germany: Bertelsmann-Stiftung.

Bull, Hedley (2002): The Anarchical Society. A Study of Order in World Politics. New York, NY; Chichester, West Sussex: Columbia University Press.

Burg, Steven L. and Paul S. Shoup (1999): The War in Bosnia-Herzegovina. Ethnic Conflict and International Intervention. Armonk, New York. London, England.: M.E. Sharpe.

Bussmann, Kai-D., Claudia Erthal and Andreas Schroth (2009): "The Effect of Banning Corporal Punishment in Europe: A Five-Nation Comparison." Halle, Germany: Martin-Luther-Universität HalleWittenberg.

Buzan, Barry and Ole Wæver (2003): Regions and Powers: The Structure of International Security. Cambridge, UK: Cambridge University Press.

Cagaptay, Soner and Tyler Evans (2012): "Turkey's Changing Relations with Iraq. Kurdistan up, Bagdad down." Policy Focus 122. Washington, D.C.: The Washington Institute for Near East Policy.

Call, Charles and Vanessa Wyeth eds (2008): Building states to build peace. Boulder, Colorado: Lynne Rienner Publishers.

Caparini, Marina (2014): "Extending State Authority in Liberia. The Gbarnga Justice and Security Hub." NUPI Report 5. Oslo, Norway: Norwegian Institute of International Affairs.

Centeno, Miguel Angel (2002): Blood and debt : war and the nation-state in Latin America. University Park, Pa.: Pennsylvania State University Press.

Chandler, David (2007): "The state-building dilemma: good governance or democratic governance." In State-building.Theory and practice, ed. Aidan Hehir. London: Routledge. 
Charley, Joseph P. Chris and Freida Ibiduni M'Cormack (2011): "Becoming and Remaining a 'Force for Good' - Reforming the Police in Post-conflict Sierra Leone." IDS Research Report 70. Brighton, UK: Institute of Development Studies.

Chesterman, Simon (2004): You, The People: The United Nations, Transitional Administration, and State-Building. Oxford, UK: Oxford University Press.

Christia, Fotini (2012): Alliance Formation in Civil Wars. New York, NY: Cambridge University Press.

Clark, Christopher (2007): Iron Kingdom. The Rise and Downfall of Prussia, 1600-1947. London, UK: Penguin Books.

Clarke, Kevin A. and David M. Primo (2012): A Model Discipline: Political Science and the Logic of Representations. Oxford, New York: Oxford University Press.

Coburn, Noah (2013): "Informal Justice and the International Community in Afghanistan." Peaceworks 84: United States Institute of Peace.

Collier, Paul and Anke Hoeffler. (1998): "On economic causes of civilwar." Oxford Economic Papers 50(4):563-573.

Collier, Paul and Anke Hoeffler. (2004): "Greed and grievance in civil war." Oxford Economic Papers 56(4):563-595.

Collins, Randall (2008): Violence: a micro-sociological theory. Princeton, NJ: Princeton Univ. Press.

Cordesman, Anthony H. (2012): "The U.S. Cost of the Afghan War: FY 2002 - FY 2013." Washington, D.C.: Center for Strategic and International Studies.

Costalli, Stefano. (2014): "Does Peacekeeping Work? A Disaggregated Analysis of Deployment and Violence Reduction in the Bosnian War." British Journal of Political Science 44(02):357-380.

CoW (2011): "State System Membership List, v2011." 2014(14.08.): Correlates of War Project.http://correlatesofwar.org accessed on 14.08. 2014

Cullather, N. (2002): "Damming Afghanistan: Modernization in a buffer state." Journal of American History 89(2):512-537.

D'Souza, Shanthie Mariet (2011): "India-Afghanistan Strategic Partnership: Beyond 2014?" ISAS Insights No. 142.

Dafoe, Allan. (2011): "Statistical Critiques of the Democratic Peace: Caveat Emptor." American Journal of Political Science 55(2):247-262.

Dahl, Robert A. (1957): "The concept of power." Behavioral Science 2(3):201-215.

Davies, Victor A.B. and Sylvain Dessy (2012): "The Political Economy of Government Revenues in Post-Conflict Resource-Rich Africa: Liberia and Sierra Leone." Working Paper Series: National Bureau of Economic Research.

De Waal, Alex. (2009): "Mission without end? Peacekeeping in the African political marketplace." International Affairs 85(1):99-113.

Deflem, Mathieu and Suzanne Sutphin. (2006): "Policing Post-War Iraq: Insurgency, Civilian Police, and the Reconstruction of Society." Sociological Focus 39(4):265-283.

Denney, Lisa. (2013): "Liberal Chiefs or Illiberal Development? The Challenge of Engaging Chiefs in DFID's Security Sector Reform Programme in Sierra Leone." Development Policy Review 31(1):5-25.

DFID (2010): "Building Peaceful States and Societies: A DFID Practice Paper." London: Department for International Development.

Dobbins, James (2007): The beginner's guide to nation-building. Santa Monica, Calif.: Rand. 
DoD (2012): "Report on Progress Toward Security and Stability in Afghanistan. Report to Congress." Washington, D.C.

Dodge, Toby. (2012): "Chapter Two: From insurgency to civil war: the purveyors of violence in Iraq." Adelphi Series 52(434-435):53-74.

Dressler, Jeffrey A. (2010): "The Haqqani Network. From Pakistan to Afghanistan." Afghanistan Report 6. Washington, D.C.: Institute for the Study of War.

Dziedzic, Michael J. and Andrew Blair (1998): "Bosnia and the International Police Task Force." In Policing the New World Disorder. Peace Operations and Public Security, eds. Robert B. Oakley, Michael J. Dziedzic and Eliot M. Golberg. Washington, DC: National Defense University Press.

Earle, Timothy K. (1997): How chiefs come to power: the political economy in prehistory. Stanford, Calif.: Stanford Univ. Press.

EBRD (2010): "Life in Transition. After the Crisis." London: European Bank for Reconstruction and Development.

EC (2007): "Communication from the Commission to the Council, the European Parliament, the European Economic and Social Committee and the Committee of the Regions - Towards an EU response to situations of fragility - engaging in difficult environments for sustainable development, stability and peace - " \{SEC(2007) 1417\}. Brussels, BE: European Commission.

EC (2014): "Enlargement." 2014(16.07.).http://ec.europa.eu/enlargement/index_en.htm accessed on 16.07. 2014

Eisner, Manuel. (2001): "Modernization, Self-Control and Lethal Violence. The Long-term Dynamics of European Homicide Rates in Theoretical Perspective." British Journal of Criminology 41(4):618-638.

Eisner, Manuel. (2003): "Long-Term Historical Trends in Violent Crime." Crime and Justice 30:83-142.

Elias, Norbert (1939[2000]): The civilizing process : sociogenetic and psychogenetic investigations. Rev. Edition. Oxford ; Malden, Mass.: Blackwell Publishers.

Elias, Norbert (1978): What is sociology? New York: Columbia University Press.

Elias, Norbert. (1983): "Über den Rückzug der Soziologen auf die Gegenwart." Kölner Zeitschrift für Soziologie und Sozialpsychologie Jg. 35(H. 1):29-40.

Elias, Norbert (1997): Über den Prozess der Zivilisation. Zweiter Band. Frankfurt a.M.: Suhrkamp.

Ertman, Thomas (1997): Birth of the Leviathan. Building States and Regimes in Medieval and Early Modern Europe. Cambridge, UK: Cambridge University Press.

Fakondo, Kadi (2010): "Reforming and Building Capacity of the Sierra Leone Police, 1999-2007." In Security Sector Reform in Sierra Leone 1997 - 2007: Views from the Front Line, eds. Peter Albrecht and Paul Jackson. Geneva: Geneva Centre for the Democratic Control of Armed Forces (DCAF).

Farrell, Theo and Antonio Giustozzi. (2013): "The Taliban at war: inside the Helmand insurgency, 2004-2012." International Affairs 89(4):845-871.

Fearon, James D. (2004): "Why Do Some Civil Wars Last So Much Longer than Others?" Journal of Peace Research 41(3):275-301.

Fearon, James D. and David D. Laitin. (2003): "Ethnicity, Insurgency, and Civil War." American Political Science Review 97(01):75-90.

Filice, Ivana, Christine Vincent, Amina Adams and Fersada Bajramovic. (1994): "BosniaHerzegovina: Cultural Profile." International Journal of Refugee Law 6(3):425-443. 
Fishman, Brian (2013): "The Taliban in Pakistan: An Overview." In Talibanistan. Negotiating the Borders between Terror, Politics and Religion, eds. Peter Bergen and Katherine Tiedemann. Oxford, New York: Oxford University Press.

Fortna, Virginia Page. (2004): "Does Peacekeeping Keep Peace? International Intervention and the Duration of Peace After Civil War." International Studies Quarterly 48(2):269-292.

Foucault, Michel (1991): "Governmentality." In The Foucault Effect. Studies in Governmentality., eds. Graham Burchell, Colin Gordon and Peter Miller. Chicago: University of Chicago Press.

Friesendorf, Cornelius. (2011): "Paramilitarization and Security Sector Reform: The Afghan National Police." International Peacekeeping 18(1):79-95.

Fukuyama, Francis (2005): State-building. Paperback ed. Edition. London: Profile Books.

Fumagalli, Matteo. (2007): "Ethnicity, state formation and foreign policy: Uzbekistan and 'Uzbeks abroad'." Central Asian Survey 26(1):105-122.

Galtung, Johan. (1990): "Cultural Violence." Journal of Peace Research 27(3):291-305.

Gberie, Lansana (2005): A dirty war in West Africa : the RUF and the destruction of Sierra Leone. London: Hurst \& Company.

Gbla, Osman. (2006): "Security sector reform under international tutelage in Sierra Leone." International Peacekeeping 13(1):78-93.

George, Alexander L. and Andrew Bennett (2005): Case studies and theory development in the social sciences. Cambridge, Mass.: MIT Press.

Gerdes, Felix (2013a): Civil War and State Formation. The Political Economy of War and Peace in Liberia. Frankfurt-on-Main, Germany: Campus Verlag.

Gerdes, Felix (2013b): "The Evolution of the Liberian State. A Study in Neo-patrimonial State Formation and Political Change. Arbeitspapier 1/2013." Hamburg, Germany.

Gerring, John, Daniel Ziblatt, Johan Van Gorp and Julián Arévalo. (2011): "An Institutional Theory of Direct and Indirect Rule." World Politics 63(03):377-433.

Giddens, Anthony (1985): The Nation-State and Violence. Berkeley and Los Angeles: University of California Press.

Giustozzi, Antonio. (2007): "Auxiliary Force or National Army? Afghanistan's 'ANA' and the CounterInsurgency Effort, 2002-2006." Small Wars \& Insurgencies 18(1):45-67.

Giustozzi, Antonio (2009): Empires of mud : war and warlords in Afghanistan. New York: Columbia University Press.

Giustozzi, Antonio (2011a): The art of coercion : the primitive accumulation and management of coercive power. New York: Columbia University Press.

Giustozzi, Antonio (2011b): "Double-Edged Swords: Armies, Elite Bargaining and State-Building." Crisis States Working Papers Series No.2 Working Paper no. 86: Crisis States Research Centre.

Giustozzi, Antonio and Mohammad Isaqzadeh (2013): Policing Afghanistan. The Politics of the Lame Leviathan. London: Hurst \& Company.

Giustozzi, Antonio and Dominique Orsini. (2009): "Centre-periphery relations in Afghanistan: Badakhshan between patrimonialism and institution-building." Central Asian Survey 28(1):1-16.

Gleditsch, Kristian Skrede. (2007): "Transnational Dimensions of Civil War." Journal of Peace Research 44(3):293-309. 
Gleditsch, Nils Petter, Peter Wallensteen, Mikael Eriksson, Margareta Sollenberg and Harvard Strand. (2002): "Armed Conflict 1946-2001: A New Dataset 39(5)." Journal of Peace Research 39(5): 615-637.

Glenny, Misha (2012): The Balkans. Nationalism, War, and the Great Powers. New York, NY: Penguin Books.

Goertz, Gary and James Mahoney (2012): A tale of two cultures : qualitative and quantitative research in the social sciences. Princeton, N.J.: Princeton University Press.

Goldstone, Jack A., Robert H. Bates, David L. Epstein, Ted Robert Gurr, Michael B. Lustik, Monty G. Marshall, Jay Ulfelder and Mark Woodward. (2010): "A Global Model for Forecasting Political Instability." American Journal of Political Science 54(1):190-208.

Goodhand, Jonathan and Aziz Hakimi (2014): "Counterinsurgency, Local Militias, and Statebuilding in Afghanistan." Peaceworks: United States Institute of Peace.

Google (2014): "Maps." 2014(14.12.2014).https://www.google.de/maps accessed on 14.12.2014 2014

Green, Daniel R. (2010): "The Fallujah awakening: a case study in counter-insurgency." Small Wars \& Insurgencies 21(4):591-609.

Griffiths, John. (1986): "What is Legal Pluralism?" The Journal of Legal Pluralism and Unofficial Law 18(24):1-55.

Guardian (2007a): "Iran's secret plan for summer offensive to force US out of Iraq."

2014(20.11.).http://www.theguardian.com/world/2007/may/22/iraq.topstories3 accessed on 20.11. 2014

Guardian (2007b): "Saudis make up 41\% of foreign fighters in Iraq."

2014(20.11.).http://www.theguardian.com/world/2007/nov/23/iraq. saudiarabia accessed on 20.11. 2014

Guardian (2013): "UN report detailing Taliban fighter deaths warns of force's illicit funding."

2014(13.03.).http://www.theguardian.com/world/2013/nov/17/un-report-taliban-fighter-deaths accessed on 13.03. 2014

Haldén, Peter. (2010): "Systems-building before state-building: on the systemic preconditions of statebuilding." Conflict, Security \& Development 10(4):519-545.

Haldén, Peter (2013): "Against Endogeneity: The systemic preconditions of state formation." In New Agendas in Statebuilding: Hybridity, contingency and history, eds. Robert Egnell and Peter Haldén. New York: Routledge.

Hänggi, Heiner (2004): "Conceptualising Security Sector Reform and Reconstruction." In Reform and Reconstruction of the Security Sector, ed. Heiner Hänggi. Münster, Germany; New Brunswick, USA: Lit Verlag; Transaction Publishers.

Hanlon, Joseph. (2005): "Is the international community helping to recreate the preconditions for war in Sierra Leone?" The Round Table 94(381):459-472.

Hänni, Adrian and Lukas Hegi (2013): "The Pakistani Godfather: The Inter-Services Intelligence and the Afghan Taliban 1994-2010." 2014(03.05.): Small Wars

Journal.http://smallwarsjournal.com/jrnl/art/the-pakistani-godfather-the-inter-services-intelligence-andthe-afghan-taliban-1994-2010 accessed on 03.05. 2014

Hazen, Jennifer M. (2013): What rebels want : resources and supply networks in wartime. Ithaca: Cornell University Press.

Hechter, Michael and William Brustein. (1980): "Regional Modes of Production and Patterns of State Formation in Western Europe." American Journal of Sociology 85(5):1061-1094. 
Hegre, Håvard, Tanja Ellingsen, Scott Gates and Nils Petter Gleditsch. (2001): "Toward a Democratic Civil Peace? Democracy, Political Change, and Civil War, 1816-1992." American Political Science Review 95(01):33-48.

Hendrix, Cullen S. (2010): "Measuring state capacity: Theoretical and empirical implications for the study of civil conflict." Journal of Peace Research 47(3):273-285.

Herbst, Jeffrey (2000): States and power in Africa : comparative lessons in authority and control. Princeton, N.J.: Princeton University Press.

Hess, Steve. (2010): "Coming to terms with neopatrimonialism: Soviet and American nation-building projects in Afghanistan." Central Asian Survey 29(2):171-187.

Hintze, Otto (1906): Staatsverfassung und Heeresverfassung. Dresden, Germany: Gehe-Stiftung.

Hobbes, Thomas (1991): Leviathan. Cambridge, UK: Cambridge Univ. Press.

Holtom, Paul (2007): United Nations Arms Embargoes. Their Impact on Arms Flows and Target Behaviour. Case study: Sierra Leone, 1997-present. Stockholm, Sweden: Stockholm International Peace Research Institute.

Horn, Adrian, Funmi Olonisakin and Gordon Peake. (2006): "United Kingdom-led Security Sector Reform in Sierra Leone." Civil Wars 8(2):109-123.

Hösch, Edgar (2008): Geschichte der Balkanländer. Von der Frühzeit bis zur Gegenwart. Munich, Germany: C.H.Beck.

HRW (1999): "Sierra Leone. Getting Away with Murder, Mutilation, Rape. New Testimonty from Sierra Leone." (3).

Hui, Victoria Tin-bor (2005): War and state formation in ancient China and early modern Europe. New York NY: Cambridge University Press.

Hultman, Lisa, Jacob Kathman and Megan Shannon. (2014): "Beyond Keeping Peace: United Nations Effectiveness in the Midst of Fighting." American Political Science Review 108(4).

Ibeanu, Okechukwu and Abubakar Momoh (2008): "State Responsiveness to Public Security Needs: The Politics of Security Decision-Making. Nigeria Country Study." CSDG Papers Number 14 London.

ICG (1999): "Republika Srpska in the Post-Kosovo Era. Collateral Damage and Transformation." ICG Balkans Report 71. Sarajevo: International Crisis Group.

ICG (2002a): "Liberia: The Key to Ending Regional Instability." Africa Report 43. Freetown/Brussels: International Crisis Group.

ICG (2002b): "Policing the Police in Bosnia: A further reform agenda." Balkan Reports 130.

Sarajevo/Brussels: International Crisis Group.

ICG (2003): "Tackling Liberia: The Eye of the Regional Storm." Africa Report 62. Freetown/Brussels: International Crisis Group.

ICG (2005): "Bosnia's Stalled Police Reform: No Progress, no EU." Europe Report 164.

Sarajevo/Brussels: International Crisis Group.

ICG (2008): "Sierra Leone: A new era of reform?" Africa Report 143. Dakar/Brussels: International Crisis Group.

ICG (2010a): "A Force in Fragments: Reconstituting the Afghan National Army." Asia Report 190: International Crisis Group.

ICG (2010b): "Guinea: Reforming the Army." Africa Report 164: International Crisis Group. 
ICG (2011): "North Kosovo: Dual Sovereignty in Practice." Europe Report 211.

Pristina/Mitrovica/Brussels: International Crisis Group.

ICG (2013): "Drones: Myths And Reality In Pakistan." Asia Report 247. Islamabad/Washington/Brussels: International Crisis Group.

ICTY (1996): "Prosecutor v. Ivica Rajic a/k/a Viktor Andric. Review of the Indictment Pursuant to Rule 61 of the Rules of Procedure and Evidence." The Hague, Netherlands.

ICTY (1999): "Prosecutor v. Du[Ko Tadi]. Judgement." Case No.: IT-94-1-A. The Hague, Netherlands.

IRBRS (2014): "Database of Economic Indicators of the Republic of Srpska." 2014(14.07.): The Republic of Srpska Investment-Development Bank.http://www.irbrs.net/statistika.aspx?lang=eng accessed on 14.07. 2014

IRoA (2004): "The Constitution of Afghanistan ". Kabul: Islamic Republic of Afghanistan.

ISAF. (2011): "ISAF Troop Numbers 2008 - 2010 (as referred by J. Bohannon)." Science 311(1256).

Isser, Deborah H., Stephen C. Lubkemann and Saah N'Tow (2009): "Looking for Justic. Liberian experiences with and perceptions of local justice options." Peaceworks. Washington, D.C.: United States Institute of Peace.

Jackson, Paul. (2005): "Chiefs, money and politicians: Rebuilding local government in post-war Sierra Leone." Public Administration and Development 25(1):49-58.

Jackson, Paul. (2007): "Reshuffling an Old Deck of Cards? The politics of local government reform in Sierra Leone." African Affairs 106(422):95-111.

Jackson, Paul. (2011): "Security Sector Reform and State Building." Third World Quarterly 32(10):18031822.

Jackson, Robert H. (1993): Quasi-States. Sovereignty, International Relations and the Third World. Cambridge, UK: Cambridge University Press.

Jelavich, Charles and Barbara Jelavich (2000): The Establishment of the Balkan National States, 18041920. Seattle and London: University of Washington Press.

Jović, Dejan. (2006): "Croatia and the European Union: a long delayed journey." Journal of Southern Europe and the Balkans Online 8(1):85-103.

Juncos, Ana E. (2011): "Europeanization by Decree? The Case of Police Reform in Bosnia*." JCMS: Journal of Common Market Studies 49(2):367-389.

Kabia, John M. (2009): Humanitarian intervention and conflict resolution in West Africa : from ECOMOG to ECOMIL. Farnham, England ; Burlington, VT: Ashgate Pub. Company.

Kalyvas, Stathis N (2008): The logic of violence in civil war. Reprinted. Edition. Cambridge: Cambridge Univ. Press.

Kalyvas, Stathis N and Nicholas Sambanis (2005): "Bosnia's Civil War. Origins and Violence Dynamics." In Understanding Civil War. Vol. 2, eds. Paul Collier and Nicholas Sambanis. Washington, D.C.: The International Bank for Reconstruction and Development / The World Bank.

Kantor, Ana and Mariam Persson (2010): "Understanding Vigilantilism. Informal Security Providers and Security Sector Reform in Liberia." Folke Bernadotte Academy.

Kaplan, Robert D. (1994): "The Coming Anarchy. How scarcity, crime, overpopulation, tribalism, and disease are rapidly destroying the social fabric of our planet." The Atlantic.

Keen, David (2005): Conflict and Collusion in Sierra Leone. Oxford, UK: James Currey Publishers. 
Khoury, Phlip S. and Joseph Kostiner (1990): Tribes and State Formation in the Middle East. Berkley: University of California Press.

Kitschelt, Herbert (2001): "Divergent Paths of Postcommunist Democracies." In Political Parties and Democracy, eds. Larry Diamond and Richard Gunther. Batlimore, ML: John Hopkins University Press.

Knight, Mark and Alpaslan Özerdem. (2004): "Guns, Camps and Cash: Disarmament, Demobilization and Reinsertion of Former Combatants in Transitions from War to Peace." Journal of Peace Research 41(4):499-516.

Knöbl, Wolfgang (1998): Polizei und Herrschaft im Modernisierungsprozeß. Staatsbildung und innere Sicherheit in Preußen, England und Amerika 1700-1914. Frankfurt am Main, Germany: Campus Verlag.

Koehler, Jan (2012): "Social Order within and beyond the Shadow of Hierarchy. Governance Patterns in Afghanistan." SFB-Governance Working Paper Series 33 Berlin: SFB 700 - Governance in Areas of Limited Statehood.

Koehler, Jan and Kristóf Gosztonyi. (2014): "The International Intervention and its Impact on Security Governance in North-East Afghanistan." International Peacekeeping 21(2):231-250.

Koloma Beck, Teresa and Klaus Schlichte (2014): Theorien der Gewalt zur Einführung. Hamburg, Germany: Junius Verlag.

Krasner, Stephen D. (2001): "Rethinking the sovereign state model." Review of International Studies 27(05):17-42.

Krech, Hans (1997): Der Bürgerkrieg in Bosnien-Herzegovina. Berlin: Verlag Dr. Köster.

Krogstad, E. G. (2012): "Security, development, and force: Revisiting police reform in Sierra Leone." African Affairs 111(443):261-280.

Labonte, Melissa T. (2012): "From patronage to peacebuilding? Elite capture and governance from below in Sierra Leone." African Affairs 111(442):90-115.

Lake, David. (2010a): "The Practice and Theory of US Statebuilding." Journal of Intervention and Statebuilding 4(3):257-284.

Lake, David A. (2010b): "Building Legitimate States after Civil Wars." In Strengthening Peace in PostCivil War States, eds. Matthew Hoddie and Caroline A. Hartzell. Chicago: University of Chicago Press.

Lampe, John R. (2000): Yugoslavia as Histoty. Twice There was a Country. Cambridge, UK: Cambridge University Press.

Le Billon, Philippe. (2001): "The political ecology of war: natural resources and armed conflicts." Political Geography 20(5):561-584.

Levy, Jack S. and William R. Thompson (2010): Causes of War. Chichester, UK: Wiley.

Lichbach, Mark Irving (1998): The Rebel's Dilemma. Ann Arbor, Michigan: The University of Michigan Press.

Lister, Sarah and Andrew Wilder (2007): "Subnational administration and state building: lessons from Afghanistan." In Governance in Post-Conflict Societies, ed. Derick W. Brinkerhoff. London and New York: Routledge.

Mac Ginty, Roger. (2010a): "Hybrid Peace: The Interaction Between Top-Down and Bottom-Up Peace." Security Dialogue 41(4):391-412.

Mac Ginty, Roger. (2010b): "Warlords and the liberal peace: state-building in Afghanistan." Conflict, Security \& Development 10(4):577-598. 
Mac Ginty, Roger (2011): International Peacebuilding and Local Resistance: Hybrid Forms of Peace. Basingstoke: Palgrave Macmillan.

Mac Ginty, Roger. (2012): "Between Resistance and Compliance: Non-participation and the Liberal Peace." Journal of Intervention and Statebuilding 6(2):167-187.

Mac Ginty, Roger and Oliver Richmond. (2007): "Myth or Reality: Opposing Views on the Liberal Peace and Post-war Reconstruction." Global Society 21(4):491-497.

Mac Ginty, Roger and Oliver P. Richmond. (2013): "The Local Turn in Peace Building: a critical agenda for peace." Third World Quarterly 34(5):763-783.

Mahoney, James and Dietrich Rueschemeyer eds (2003): Comparative historical analysis in the social sciences. Cambridge, U.K. ; New York: Cambridge University Press.

Mahsud, Mansur Khan (2013): "The Taliban in South Waziristan." In Talibanistan. Negotiating the Borders between Terror, Politics, and Religion, ed. Peter Bergen. Oxford, UK: Oxford University Press.

Malešević, Siniša (2010): The Sociology of War and Violence. Cambridge, UK: Cambridge University Press.

Malešević, Siniša. (2012): "Did Wars Make Nation-States in the Balkans?: Nationalisms, Wars and States in the 19th and early 20th Century South East Europe." Journal of Historical Sociology 25(3):299-330.

Malkasian, Carter (2013): War comes to Garmser. Thirty Years of Conflict on the Afghan Frontier. Oxford, UK: Oxford University Press.

Maloney, Sean M. (2008): "A violent impediment: the evolution of insurgent operations in Kandahar province 2003-07." Small Wars \& Insurgencies 19(2):201-220.

Mann, Michael. (1984): "The autonomous power of the state: its origins, mechanisms and results." European Journal of Sociology / Archives Européennes de Sociologie 25(02):185-213.

Mann, Michael (1993): The sources of social power Vol. 2. The rise of classes and nation-states, 1760 1914. Cambridge: Cambridge Univ. Press.

Manning, Carrie. (2003): "Local Level Challenges to Post-conflict Peacebuilding." International Peacekeeping 10(3):25-43.

Manning, Ryann Elizabeht. (2009): "The Landscape of Local Authority in Sierra Leone. How

"Traditional" and "Modern" Justice Systems Interact." justice \& development working paper series 1(1).

Marenin, Otwin. (1982): "Parking tickets and class repression: The concept of policing in critical theories of criminal justice." Contemporary Crises 6(3):241-266.

Marenin, Otwin. (2005): "Building a Global Police Studies Community." Police Quarterly 8(1):99-136.

Martin, Mike (2011): "A Brief History of Helmand." Afghan COIN Centre.

Maxwell, Rohan (2014): "Bosnia-Herzegovina: From Three Armies to One." In New Armies from Old. Merging Competing Military Forces after Civil Wars., ed. Roy Licklider. Washington, D.C.: Georgetown University Press.

Mayntz, Renate and Fritz W Scharpf (1995): "Der Ansatz des akteurszentrierten Institutionalismus." In Gesellschaftliche Selbstregelung und politische Steuerung, eds. Renate Mayntz and Fritz W Scharpf. Frankfurt, New York: Campus Verlag.

McFate, Sean (2011): "There's a New Sheriff in Town: DDR-SSR and the Monopoly of Force." In Monopoly of Force. The Nexus of DDR and SSR, eds. Melanne A. Civi and Michael Miklaucic. Washington, D.C.: National Defense University Press.

Merry, Sally Engle. (1988): "Legal Pluralism." Law \& Society Review 22(5):869-896. 
Migdal, Joel S. (1988): Strong societies and weak states : state-society relations and state capabilities in the Third World. Princeton, N.J.: Princeton University Press.

Migdal, Joel S. and Klaus Schlichte (2005): "Rethinking the State." In The Dynamics of States, ed. Klaus Schlichte. Hampshire, UK. Burlington, VT.: Ashgate Publishing Limited.

Møller, Jørgen and Svend-Erik Skaaning. (2011): "Stateness first?" Democratization 18(1):1-24.

Morton, Matthew D. (2012): "Three Hearts in the Chest of One State: The Armed Forces of Bosnia and Herzegovina." The Journal of Slavic Military Studies 25(4):512-532.

MRU (2014): "The Mano River Union - Official Website."

2014(05.12.).http://www.manoriverunion.int/About_Us.html accessed on 05.12. 2014

Muehlmann, Thomas. (2008): "Police Restructuring in Bosnia-Herzegovina: Problems of

Internationally-led Security Sector Reform." Journal of Intervention and Statebuilding 2(1):1-22.

Münch, Philipp (2013): "Local Afghan Power Structures and the International Military Intervention. A review of developments in Badakhshan and Kunduz provinces." AAN Thematic Report 03/2013: Afghanistan Analysts Network.

Munive, Jairo and Stine Finne Jakobsen. (2012): "Revisiting DDR in Liberia: exploring the power, agency and interests of local and international actors in the 'making' and 'unmaking' of combatants." Conflict, Security \& Development 12(4):359-385.

Murray, Tonita. (2007): "Police-Building in Afghanistan: A Case Study of Civil Security Reform." International Peacekeeping 14(1):108-126.

Murtazashvili, Jennifer Brick. (2014): "Informal Federalism: Self-Governance and Power Sharing in Afghanistan." Publius: The Journal of Federalism 44(2):324-343.

Nasr, Vali and Ray Takeyh. (2008): "The Costs of Containing Iran: Washington's Misguided New Middle East Policy." Foreign Affairs 87(1):85-94.

NATO (2005): "NATO to head South in Afghanistan "

2014(19.02.).http://www.nato.int/docu/update/2005/12-december/e1208a.htm accessed on 19.02. 2014

NATO (2012): "Chicago Summit Declaration on Afghanistan."

2014(11.11.).http://www.nato.int/cps/en/natolive/official_texts_87595.htm accessed on 11.11. 2014

NATO (2013a): "Afghan National Security Forces (ANSF)."

2014(14.03.).http://www.nato.int/nato_static/assets/pdf/pdf_2013_06/20130604_130604-mb-ansf.pdf accessed on 14.03. 2014

NATO (2013b): "NATO Secretary General welcomes Afghan transition announcement "

2014(13.03.).http://www.nato.int/cps/en/natolive/news_101482.htm accessed on 13.03. 2014

NATO (2014): "NATO's relations with Bosnia and Herzegovina."

2014(09.10.).http://www.nato.int/cps/en/natolive/topics_49127.htm accessed on 09.10. 2014

Nelson-Williams, Alfred (2009): "Security System Transformation in Sierra Leone, 1997-2007.

Restructuring the Republic of Sierra Leone Armed Forces (RSLAF). In: Albrecht and Jackson (2009):

Security Sector Reform in Sierra Leone 1997-2007. Views from the Frontline." Geneva, CH: Geneva

Center for the Democratic Control of Armed Forces (DCAF).

Nilsson, Desirée and Mimmi Söderberg Kovacs. (2013): "Different Paths of Reconstruction: Military Reform in Post-War Sierra Leone and Liberia." International Peacekeeping 20(1):2-16.

North, Douglass Cecil (1990): Institutions, Institutional Change and Economic Performance. Cambridge, UK: Cambridge University Press. 
North, Douglass Cecil, John Joseph Wallis and Barry R. Weingast (2009): Violence and social orders : a conceptual framework for interpreting recorded human history. Cambridge ; New York: Cambridge University Press.

NYTimes (1997a): "NATO Plans to Disarm Paramilitary Forces in Bosnia." 2014(02.11.).http://www.nytimes.com/1997/08/09/world/nato-plans-to-d isarm-paramilitary-forces-inbosnia.html accessed on 02.11. 2014

NYTimes (1997b): "NATO Troops raid Serb Hard-Liners in a Bosnian City." 2014(02.11.).http://www.nytimes.com/1997/08/21/world/nato-troops-raid-serb-hard-liners-in-a-bosniancity.html accessed on 02.11. 2014

NYTimes (2005): "Building an Afghan Army and Learning a Lesson in Patience." 2014(12.11.).http://www.nytimes.com/2005/09/25/international/middleeast/25troops.html?fta=y\&_r=0 accessed on 12.11. 2014

NYTimes (2014a): "Behind the Masks in Ukraine, Many Faces of Rebellion."

2014(18.06.2014).http:/www.nytimes.com/2014/05/04/world/europe/behind-the-masks-in-ukraine-manyfaces-of-rebellion.html?_r=0 accessed on 18.06.2014 2014

NYTimes (2014b): "War Deaths Top 13,000 in Afghan Security Forces." 2014(13.03.). New York, US.http://www.nytimes.com/2014/03/04/world/as ia/afghan-cabinet-releases-data-on-deaths-of-securitypersonnel.html?_r=0\&gwh=B54611D3640181CA9AAF08C5BA17534F\& gwt $=$ regi accessed on 13.03 . 2014

NYTimes (2014c): "Wary Tribal Alliances, Born of Necessity, Offer Hope in Iraq." 2014(20.11.).http:/www.nytimes.com/2014/10/07/world/middleeast/promise-is-seen-in-deals-with-tribesin-iraqs-battle-against-isis.html accessed on 20.11. 2014

OECD (2007a): "The OECD DAC Handbook on Security System Reform (SSR): Supporting Security and Justice." Paris.

OECD (2007b): "Principles for Good International Engagement in Fragile States \& Situations." Principles April 2007: Organization for Economic Cooperation and Development.

Olonisakin, Funmi (2008): Peacekeeping in Sierra Leone : the story of UNAMSIL. Boulder: Lynne Rienner Publishers.

Olson, Mancur. (1993): "Dictatorship, Democracy, and Development." The American Political Science Review 87(3):567-576.

Oschlies, Wolf (2004): "Das politische System Bosnien-Hercegovinas." In Die politischen Systeme Osteuropas, ed. Wolfgang Ismayr. Wiesbaden, Germany: VS Verlag.

Padurariu, Amelia. (2014): "The Implementation of Police Reform in Bosnia and Herzegovina: Analysing UN and EU Efforts." 2014 3(1).

Paris, Roland (2004): At War's End. Building Peace after Civil Conflict. Cambridge, UK: Cambridge University Press.

Paris, Roland and Timothy D Sisk eds (2009): The dilemmas of statebuilding. London: Routledge.

Perdan, Slobodan. (2006): "Security sector reform: The building of security in Bosnia and Herzegovina." Conflict, Security \& Development 6(2):179-209.

Peters, Krijn and Paul Richards. (2011): "Rebellion and Agrarian Tensions in Sierra Leone." Journal of Agrarian Change 11(3):377-395.

Pierson, Christopher (2011): The modern state. 3rd Edition. London ; New York: Routledge. 
Pierson, Paul (2004): Politics in time : history, institutions, and social analysis. Princeton: Princeton University Press.

Pietz, Tobias (2006): "Overcoming the failings of Dayton: Defense reform in Bosnia-Herzegovina." In Bosnian Security After Dayton: New Perspectives, ed. Michal A. Innes. New York, NY: Routledge.

Pinker, Steven (2011): The Better Angels of Our Nature: Why Violence Has Declined. New York, NY: Viking Adult.

Pinney, Rob. (2014): "Can the Sri Lanka Army be Described as a Counterinsurgency Force?" Small Wars Journal.

Planty, Donald J. and Robert M. Perito (2013): "Police Transition in Afghanistan." Special Report 322: United States Institute of Peace.

Popitz, Heinrich (2004): Phänomene der Macht. Tübingen: Mohr.

Powell, J. M. and C. L. Thyne. (2011): "Global instances of coups from 1950 to 2010: A new dataset." Journal of Peace Research 48(2):249-259.

Przeworski, Adam (1991): Democracy and the market : political and economic reforms in Eastern Europe and Latin America. Cambridge ; New York: Cambridge University Press.

Pugh, Michael. (2004): "Peacekeeping and critical theory." International Peacekeeping 11(1):39-58.

Pugh, Michael, Neil Cooper and Jonathan Goodhand (2003): War Economies in a Regional Context: Challenges of Transformation. Boulder, Colorado: Lynne Rienner Publishers.

Radin, Andrew (2012): "A Laboratory for State Building: Police and Military Reform in East Timor." Political Science Department Working Paper 2012-11: Massachusetts Institute of Technology.

Rashid, Ahmed (2000): Taliban. islam, Oil and the New Great Game in Central Asia. London, UK: I.B. Tauris.

Rashid, Ismael (2009): "Serving the Nation?": The Disintegration and Reconstitution of the Sierra Leone Army, 1961 - 2007." In Rescuing a Fragile State: Sierra Leone 2002-2008, ed. Lansana Gberie. Waterloo, Ontario: Press of Wilfrid Laurier University.

Rashid, Ismael. (2013): "The Sierra Leone Civil War and the Remaking of ECOWAS." Research in Sierra Leone Studies (RISLS) 1(1).

Reiner, Robert (2010): The Politics of the Police. Oxford, UK: Oxford University Press.

Reinhard, Wolfgang (1999): Geschichte der Staatsgewalt. Eine vergleichende Verfassungsgeschichte Europas von den Anfängen bis zur Gegenwart. Munich, Germany: C.H. Beck Verlag.

Reno, William (1995): Corruption and state politics in Sierra Leone. Cambridge, UK: Cambridge University Press.

Reno, William. (2008): "Anti-corruption Efforts in Liberia: Are they Aimed at the Right Targets?" International Peacekeeping 15(3):387-404.

Reus-Smit, Christian. (2013): "The concept of intervention." Review of International Studies 39(05):1057-1076.

Reuters (2014a): "Afghan casualties on battlefield at unsustainably high level: U.S. general." 2014(11.11.). Washington.http://www.reuters.com/article/2014/11/05/us-usa-afghanistanidUSKBNOIP2MM20141105 accessed on 11.11. 2014

Reuters (2014b): "Serbia pledges support for single Bosnia amid secessionist rhetoric." 2014(16.06.).http://www.reuters.com/article/2014/05/13/us-bosnia-serbia-idUSBREA4C0FU20140513 accessed on 16.06. 2014 
Richards, Paul (1996): Fighting for the rain forest : war, youth \& resources in Sierra Leone. Portsmouth, N.H.: Heinemann.

Richmond, Oliver P. (2005): The transformation of peace. Basingstoke England ; New York: Palgrave Macmillan.

Richmond, Oliver P. (2006): "The problem of peace: understanding the 'liberal peace'." Conflict, Security \& Development 6(3):291-314.

Richmond, Oliver P. (2010): "Resistance and the Post-liberal Peace." Millennium - Journal of International Studies.

Richmond, Oliver P. (2014): "Peace During and After the Age of Intervention." International Peacekeeping 21(4):509-519.

Ricks, Thomas E (2007): Fiasco. New York: Penguin Press.

Rohlfing, Ingo (2012): Case Studies and Causal Inference. Basingstoke: Palgrave Macmillan.

Ross, Michael L. (1999): "The Political Economy of the Resource Curse." World Politics 51(02):297-322.

Ross, Michael L. (2004): "What Do We Know about Natural Resources and Civil War?" Journal of Peace Research 41(3):337-356.

Rubin, Barnett (2008): "The Politics of Security in Postconflict Statebuilding " In Building States to Build Peace, eds. Charles Call and Vanessa Wyeth. Boulder, Colorado: Lynne Rienner Publishers.

Rubin, Barnett R. (1995): The fragmentation of Afghanistan : state formation and collapse in the international system. New Haven, CT: Yale University Press.

Ruggeri, Andrea, Theodora-Ismene Gizelis and Han Dorussen. (2013): "Managing Mistrust: An Analysis of Cooperation with UN Peacekeeping in Africa." Journal of Conflict Resolution 57(3):387-409.

Ruggie, John Gerard. (1993): "Territoriality and beyond: problematizing modernity in international relations." International Organization 47(01):139-174.

Ruttig, Thomas (2009): "The Other Side. Dimensions of the Afghan Insurgency: Causes, Actors and Approaches to 'Talks'." Afghanistan Analysts Network.

Saikal, Amin. (2006a): "Afghanistan's transition: isaf's stabilisation role?" Third World Quarterly 27(3):525-534.

Saikal, Amin. (2006b): "Securing Afghanistan's border." Survival 48(1):129-142.

Salehyan, Idean. (2007): "Transnational Rebels: Neighboring States as Sanctuary for Rebel Groups." World Politics 59(2):217-242.

Saltmarshe, Douglas and Abhilash Mehdi (2011): "Local Governance in Afghanistan. A View from the Ground." Kabul, Afghanistan: Afghanistan Research and Evaluation Unit.

Sarkees, Meredith Reid, Frank Whelon Wayman and J. David Singer. (2003): "Inter-State, IntraState, and Extra-State Wars: A Comprehensive Look at Their Distribution over Time, 1816-1997." International Studies Quarterly 47(1):49-70.

Schetter, Conrad (2003): Ethnizität und ethnische Konflikte in Afghanistan. Berlin: Dietrich Reimer Verlag.

Schetter, Conrad, Rainer Glassner and Masood Karokhail (2006): "Understanding Local Violence. Security Arrangements in Kandahar, Kunduz and Paktia." Working Papers Series 67. Local Governance and Statehood in the Amu Darya Borderlands 3: Center for Development Research, University of Bonn.

Schlichte, Klaus (2005a): Der Staat in der Weltgesellschaft : politische Herrschaft in Asien, Afrika und Lateinamerika. Frankfurt/Main ; New York: Campus. 
Schlichte, Klaus (2005b): The dynamics of states : the formation and crises of state domination. Aldershot, Hants, England ; Burlington, VT: Ashgate.

Schlichte, Klaus (2009): In the Shadow of Violence: The Politics of Armed Groups. Frankfurt. New York.: Campus Verlag.

Schmeidl, Susanne and Masood Karokhail. (2009): "The Role of Non-State Actors in "CommunityBased Policing' - An Exploration of the Arbakai (Tribal Police) in South-Eastern Afghanistan." Contemporary Security Policy 30(2):318-342.

Schneider, Carsten Q. and Claudius Wagemann. (2006): "Reducing complexity in Qualitative Comparative Analysis (QCA): Remote and proximate factors and the consolidation of democracy." European Journal of Political Research 45(5):751-786.

Schröder, Ursula C. and Johannes Kode. (2012): "Rule of Law and Security Sector Reform in International State-Building: Dilemmas of Converging Agendas." Hague Journal on the Rule of Law 4(Special Issue 01):31-53.

Sedra, Mark. (2013): "The hollowing-out of the liberal peace project in Afghanistan: the case of security sector reform." Central Asian Survey 32(3):371-387.

SL (2009): "The Chieftaincy Act 2009." Freetown: President and Members of Parliament of Sierra Leone. SLTRC (2004): "Witness to Truth: Report of the Sierra Leone Truth and Reconciliation Commission."

Sørensen, Georg. (1999): "Sovereignty: Change and Continuity in a Fundamental Institution." Political Studies 47(3):590-604.

Spruyt, Hendrik (1994): The Sovereign State and its Competitors. Princeton, New Jersey: Princeton University Press.

Staniland, Paul. (2012): "States, Insurgents, and Wartime Political Orders." Perspectives on Politics 10(02):243-264.

Starčević-Srkalović, Lejla (2010): The Democratization Process in Post-Dayton Bosnia and Herzegovina and the Role of the European Union. Baden-Baden, germany: Nomos Verlagsgesellschaft.

Stedman, Stephen John. (1997): "Spoiler Problems in Peace Processes." International Security 22(2):553.

Stein, Matthew. (2012): "Uzbekistan's View of Security in Afghanistan After 2014." Military Review May-June.

Stroh, Sabine. (2003): "Neue Außenbeziehungen im Dreieck Kroatien Bosnien und Herzegowina Serbien und Montenegro." Südosteuropa. Zeitschrift für Politik und Gesellschaft 52(07-09):355-380.

Suhrke, Astri. (2012): "Waging War and Building Peace in Afghanistan." International Peacekeeping 19(4):478-491.

Telegraph (2009): "Afghan governor turned 3,000 men over to Taliban."

2014(17.11.).http://www.telegraph.co.uk/news/worldnews/asia/afghanistan/6615329/Afghan-governorturned-3000-men-over-to-Taliban.html accessed on 17.11. 2014

Telegraph (2012): "David Cameron warned that Afghanistan pullout could allow al-Qaeda to return." 2014(06.05.).http:/www.telegraph.co.uk/news/worldnews/asia/afghanistan/9450503/David-Cameronwarned-that-Afghanistan-pullout-could-allow-al-Qaeda-to-return.html accessed on 06.05. 2014

TheAtlantic (2012): "The U.S. Spends \$14K per Afghan Troop per Year, but Each Earns \$1,872." 2014(20.09.).http://www.theatlantic.com/international/archive/2012/04/the-us-spends-14k-per-afghantroop-per-year-but-each-earns-1-872/255934/ accessed on 20.09. 2014 
TheEconomist (2014): "Syria's deadlocked war. No solution."

2014(11.11.).http://www.economist.com/news/briefing/21620217-it-will-take-more-air-strikes-endconflict-no-solution accessed on 11.11. 2014

Thies, Cameron G. (2010): "Of rulers, rebels, and revenue: State capacity, civil war onset, and primary commodities." Journal of Peace Research 47(3):321-332.

Thies, Cameron G. (2004): "State Building, Interstate and Intrastate Rivalry: A Study of Post-Colonial Developing Country Extractive Efforts, 1975-2000." International Studies Quarterly 48(1):53-72.

Thies, Cameron G. (2005): "War, Rivalry, and State Building in Latin America." American Journal of Political Science 49(3):451-465.

Thomson, Brian (2007): "Sierra Leone: Reform or Relapse? Conflict and Governance Reform." London: Chatham House.

Thomson, Janice E. (1995): "State Sovereignty in International Relations: Bridging the Gap between Theory and Empirical Research." International Studies Quarterly 39(2):213-233.

Tilly, Charles (1975): The formation of national states in Western Europe. Princeton, NY: Univ. Press.

Tilly, Charles (1985): "War Making and State Making as Organized Crime." In Bringing the State Back In, eds. Peter B. Evans, Dietrich Rueschemeyer and Theda Skocpol. Cambridge, UK: Cambridge University Press.

Tilly, Charles (1992): Coercion, capital, and European states, AD 990-1992. Rev. pbk. Edition. Cambridge, MA: Blackwell.

Trotha, Trutz von (1995): "Ordnungsformen der Gewalt oder Aussichten auf das Ende des staatlichen Gewaltmonopols." In Politische Institutionen im Wandel. Kölner Zeitschrift für Soziologie und Sozialpsychologie, Sonderheft, 35, ed. Birgitta Nedelmann. Opladen, Germany: Westdeutscher Verlag.

Trotha, Trutz von. (1996): "From Administrative to Civil Chieftaincy." The Journal of Legal Pluralism and Unofficial Law 28(37-38):79-107.

Trotha, Trutz von. (2000): "Die Zukunft liegt in Afrika. Vom Zerfall des Staates, von der Vorherrschaft der konzentrischen Ordnung und vom Aufstieg der Parastaatlichkeit." Leviathan 28(2):253-279.

U.S.Army (2007): The U.S. Army/Marine Corps counterinsurgency field manual : U.S. Army field manual no. 3-24 : Marine Corps warfighting publication no. 3-33.5. Chicago, Ill.: University of Chicago Press.

UCDP (2014a): "UCDP Battle-Related Deaths Dataset v.5-2014, 1989-2013." 2014(08.12.): Uppsala Conflict Data Program.www.ucdp.uu.se/database accessed on 08.12. 2014

UCDP (2014b): UCDP/PRIO Armed Conflict Dataset v.4-2014a, 1946 - 2013. Uppsala: Uppsala Conflict Data Program.

UN (1995): "General Framwork Agreement for Peace in Bosnia and Herzegovina ".

UN (2001a): "Agreement on Provisional Arrangements in Afghanistan Pending the Re-Establishment of Permanent Government Institutions."

UN (2001b): "Sierra Leone: village chiefs aid disarmament effort in Kono, UN reports." 2014(20.11.).http://www.un.org/apps/news/story.asp?NewsID=388 accessed on 20.11.2014

UN (2008a): "Securing peace and development: the role of the United Nations in supporting security sector reform. Report of the Secretary-General." A/62/659-S/2008/39: UN General Assembly.

UN (2008b): "United Nations Peacekeeping Operations. Principles and Guidelines." New York, NY: United Nations Secretariat, Department of Peacekeeping Operations. 
UN (2014): "Disarmament, Demobilization and Reintegration."

2014(28.07.).http://www.un.org/en/peacekeeping/issues/ddr.shtml accessed on 28.07. 2014

UNAMA (2014): "Afghanistan. Annual Report 2013. Protection of Cvilians in Armed Conflict.". Kabul: UNAMA and UNHCR.

UNODC (2011): "Corruption in Bosnia and Herzegovina: Bribery as experienced by the population." Vienna: United Nations Office on Drugs and Crime.

UNODC (2013): "Global Study on Homicide 2013. Trends, Contexts, Data." Vienna: United Nations Office on Drugs and Crime.

UNSC (1999a): "Peace Agreement between the Government of Sierra Leone and the Revolutionary United Front of Sierra Leone ". Lomé, Togo.

UNSC (1999b): "Resolution 1270." New York, NY: United Nations Security Council.

UNSC (2000a): "Fifth Report of the Secretary-General on the United Nations Mission in. Sierra Leone. Document no. S/2000/751."

UNSC (2000b): "Fourth Report of the Secretary-General on the United Nations Mission in. Sierra Leone. Document no. S/2000/455.".

UNSC (2000c): "Report of the Panel of Experts appointed pursuant to Security Council resolution 1306 (2000), paragraph 19, in relation to Sierra Leone. Document no. S/2000/1195."

UNSC (2000d): "Resolution 1289." New York, NY: United Nations Security Council.

UNSC (2001a): "Ninth Report of the Secretary-General on the United Nations Mission in. Sierra Leone. Document no. S/2001/228.".

UNSC (2001b): "Report of the Panel of Experts pursuant to Security Council resolution 1343 (2001), paragraph 19, concerning Liberia. Document no. S/2001/1015."

UNSC (2001c): "Resolution 1346." New York, NY: United Nations Security Council.

UNSC (2001d): "Tenth Report of the Secretary-General on the United Nations Mission in. Sierra Leone. Document no. S/2001/627."

UNSC (2001e): "Twelth Report of the Secretary-General on the United Nations Mission in. Sierra Leone. Document no. S/2001/1195."

UNSC (2013): "Resolution 2098." New York, NY: United Nations Security Council.

USAID (2005): "Fragile States Strategy." Washington, D.C.: U.S. Agency for International Development.

Vetschera, Heinz and Matthieu Damian. (2006): "Security sector reform in Bosnia and Herzegovina: The role of the international community." International Peacekeeping 13(1):28-42.

Waldman, Matt (2010): "The Sun in the Sky: The Relationship between Pakistan's ISI and Afghan Insurgents." Discussion Paper 18. London: Crisis States Research Centre.

Wallis, Joanne. (2012): "A liberal-local hybrid peace project in action? The increasing engagement between the local and liberal in Timor-Leste." Review of International Studies 38(04):735-761.

Wardak, Ali and John Braithwaite. (2013): "Crime and War in Afghanistan: Part II: A Jeffersonian Alternative?" British Journal of Criminology 53(2):197-214.

WashingtonPost. (2005): "Outside Iraq but Deep in the Fight. A Smuggler of Insurgents Reveals Syria's Influential, Changing Role." The Washington Post(June 8 2005):A01. 
WashingtonPost (2008): "A sober assessment of Afghanistan."

2014(05.05.).http://www.washingtonpost.com/wp-

dyn/content/article/2008/06/14/AR2008061401639.html accessed on 05.05. 2014

WashingtonPost (2014): "Iraq's Sunni tribal leaders say fight for Fallujah is part of a revolution." 2014(12.12.).http://www.washingtonpost.com/world/middle_east/iraqs-sunni-tribal-leaders-say-fight-forfallujah-is-part-of-a-revolution/2014/03/12/cac86d7a-9f19-11e3-b8d8-94577ff66b28_story.html accessed on 12.12. 2014

Webber, Douglas. (2010): "The regional integration that didn't happen: cooperation without integration in early twenty-first century East Asia." The Pacific Review 23(3):313-333.

Weber, Max (1972): Wirtschaft und Gesellschaft. Tübingen: J.C.B. Mohr.

Wesley, Michael. (2008): "The State of the Art on the Art of State Building." Global Governance: A Review of Multilateralism and International Organizations 14(3):369-385.

WhiteHouse (2009): "Remarks by the President in Address to the Nation on the Way Forward in Afghanistan and Pakistan." 2014(11.11.). West Point, New York.http://www.whitehouse.gov/the-pressoffice/remarks-president-address-nation-way-forward-afghanistan-and-pakistan accessed on 11.11. 2014

Wikileaks (2009): "Police-military Relationship Strained." 2014(14.01.). Freetown, Sierra Leone: US Embassy.http://cablegatesearch.net/cable.php?id=09FREETOWN393\&q=armed\%20forces accessed on 14.01. 2014

Wilde, Andreas and Katja Mielke. (2013): "Order, stability, and change in Afghanistan: from top-down to bottom-up state-making." Central Asian Survey 32(3):353-370.

Willenberg, Sabine. (2007): "Die Beziehungen zwischen Serbien und Bosnien \& Herzegowina durch das „Brennglas Kosovo“." Südosteuropa Mitteilungen 47(05-06):6-21.

Wilson, Jeremy M. (2006): "Law and Order in an Emerging Democracy: Lessons from the Reconstruction of Kosovo's Police and Justice Systems." The ANNALS of the American Academy of Political and Social Science 605(1):152-177.

Wlodarczyk, Nathalie. (2009): "Politically Enfranchising the Non-political: Safeguarding Peace through Civic Education and Inclusion? The Civil Defence Forces in Sierra Leone." Civil Wars 11(2):200-214.

WorldBank (2013a): "Afghanistan Economic Update - April 2013." Poverty Reduction, and Economic Management, South Asia Region.

WorldBank (2013b): "Worldwide Governance Indicators

Documentation."http://info.worldbank.org/governance/wgi/resources.htm accessed on

WorldBank (2014): "World Bank Open Data." 2014(02.04.).http://data.worldbank.org/ accessed on 02.04. 2014

Younossi, Obaid, Peter Dahl Thruelsen, Jonathan Vaccaro, Jerry M. Sollinger and Brian Grady (2009): "The Long March. Building an Afghan National Army." Santa Monica, CA: RAND National Defense Research Institute.

Yusuf, Moeed, Huma Yusuf and Salman Zaidi (2011): "Pakistan, the United States and the End Game in Afghanistan: Perceptions of Pakistan's Foreign Policy Elite." Jinnah Institute.

Zahar, Marie-Joëlle (2004): "Republika Srpska." In De Facto States. The Quest for Sovereignty, eds. Tozun Bahcheli, Barry Bartmann and Henry Srebnik. Oxon, UK; New York, NY: Routledge.

Zuercher, Christoph, Carrie Manning, Kristie D. Evenson, Rachel Hayman, Sarah Riese and Nora Roehner (2013): Costly Democracy. Peacebuilding and Democratization After War. Stanford, Cal.: Stanford University Press. 
Zwierzchowski, Jan and Ewa Tabeau (2010): "The 1992-95 War in Bosnia and Herzegovina: CensusBased Multiple System Estimation of Casualties' Undercount." Conference Paper for the International Research Workshop on 'The Global Costs of Conflict' Berlin: The Households in Conflict Network (HiCN) and The German Institute for Economic Research (DIW Berlin). 


\section{Statement of Originality}

I hereby certify that the dissertation was

- completed without any unauthorized aid/s,

- that only those sources and aids where used as are referenced,

- $\quad$ and that all exerts, citations and ideas are indicated.

Benjamin Brast 